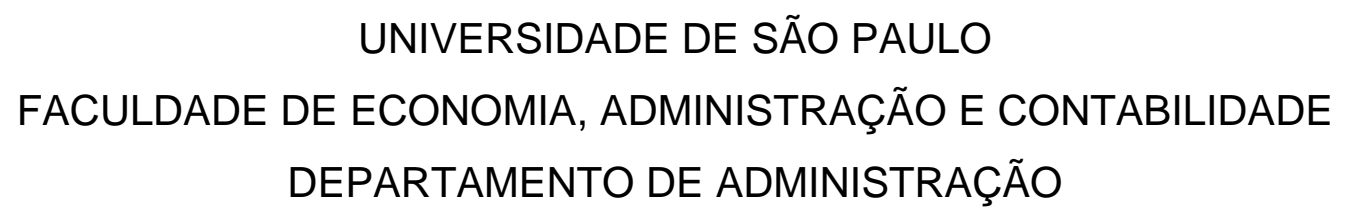

\title{
TOMADA DE DECISÃO E RISCO: A ADMINISTRAÇÃO DA INOVAÇÃO EM PEQUENAS INDÚSTRIAS QUÍMICAS
}

ANTONIO LUIZ ROCHA DACORSO

Orientador: Prof. Dr. Abraham Sin Oih Yu

SÃO PAULO

2000 
Reitor da Universidade de São Paulo Prof. Dr. Jacques Marcovitch

Diretor da Faculdade de Economia, Administração e Contabilidade Prof. Dr. Denisard Cnéio de Oliveira Alves

Chefe do Departamento de Administração

Prof. Dr. Claudio Felisoni de Angelo 


\author{
UNIVERSIDADE DE SÃO PAULO \\ FACULDADE DE ECONOMIA, ADMINISTRAÇÃO E CONTABILIDADE \\ DEPARTAMENTO DE ADMINISTRAÇÃO
}

\title{
TOMADA DE DECISÃO E RISCO: A ADMINISTRAÇÃO DA INOVAÇÃO EM PEQUENAS INDÚSTRIAS QUÍMICAS
}

\author{
ANTONIO LUIZ ROCHA DACORSO
}

Dissertação apresentada ao Departamento de Administração da Faculdade de Economia, Administração e Contabilidade da Universidade de São Paulo para obtenção do Título de Mestre em Administração

Orientador: Prof. Dr. Abraham Sin Oih Yu

\author{
SÃO PAULO
}

2000 


\section{FICHA CATALOGRÁFICA}

\section{Dacorso, Antonio Luiz Rocha}

Tomada de decisão e risco: a administração da inovação em pequenas indústrias químicas / Antonio Luiz Rocha Dacorso. _ São Paulo: FEA/USP, 2000. $236 \mathrm{p}$

Dissertação - Mestrado Bibliografia.

1. Decisão - Teoria 2. Inovações tecnológicas - Administração 3. Risco 4. Indústria química 5. Microempresas 6. Tese I. Faculdade de Economia, Administração e Contabilidade da USP.

CDD - 658.406 
"A vida virtuosa é uma vida inspirada pelo amor e guiada pelo conhecimento" Bertrand Russel. 
Aos meus pais e à minha filha Priscila, que me motivaram para este trabalho. 


\section{AGRADECIMENTOS}

Para realizar este trabalho contei com a contribuição e apoio de várias pessoas e organizações. Sou particularmente grato à CAPES, que me forneceu uma bolsa de estudos para desenvolver esse trabalho e aos dirigentes das cinco empresas, que permitiram o meu acesso para realizar a pesquisa e se dispuseram a colaborar.

Ao Prof. Dr. Abraham Sin Oih Yu, por sua orientação, seu estímulo e confiança, sem os quais não teria sido possível esta dissertação.

Aos professores da FEA / USP, e em particular ao Prof. Dr. Antonio Zoratto Sanvicente, Prof. Dr. Gilberto de Andrade Martins e Prof. Dr. Marilson Alves Gonçalves, com os quais tive o prazer de conviver e aprender.

Aos colegas Cristina Andrews, Rosa Teresa Moreira Machado, Silvana Prata Camargos, Valdeir Rejanildo VidriK e Willy Hoppe Sousa, que compartilharam comigo tantos momentos da nossa vida acadêmica.

À Etel, minha companheira, pelo carinho, compreensão e amor que recebi. 


\section{RESUMO}

A capacidade de inovar das organizações é o grande diferencial competitivo que surge nesta década. Nestas condições, constata-se a existência de um grave problema para a economia brasileira: a falta de capacidade inovadora das pequenas empresas tradicionais. Apesar da significativa participação da pequena empresa na economia brasileira, aparentemente essas empresas ainda apresentam uma baixa capacidade de inovar e competir no mercado globalizado.

O presente trabalho aborda esta questão, focalizando a tomada de decisão em inovação na pequena empresa. O estudo de por que e como a pequena indústria brasileira se decide por uma inovação, possibilitou aprofundar o conhecimento do processo de inovação, gerando hipóteses que podem auxiliar na administração dessas empresas.

A análise da tomada de decisão em inovação abrange inevitavelmente uma situação de incerteza e risco, que são conceitos abordados nas mais diversas áreas, tais como economia, administração, psicologia, filosofia, sociologia e outras, com um caráter descritivo ou prescritivo. Entender como estes fatores atuam no processo de decisão em inovação, para as pequenas indústrias, foi o grande desafio deste trabalho.

O estudo, de caráter exploratório, foi desenvolvido por meio de levantamento bibliográfico e de estudo de múltiplos casos, envolvendo cinco pequenas indústrias químicas. Adotou-se uma empresa como caso piloto e as outras como replicação da pesquisa.

A análise comparativa dos casos pesquisados demonstra quais são os principais fatores atuantes no processo de decisão na pequena indústria química e possibilita especulações sobre possíveis modelos para a tomada de decisão. 


\begin{abstract}
A corporation's capacity to innovate is its greatest competitive differential in this decade. Due to this fact, the inability of small, traditional firms to innovate is a serious problem for the Brazilian economy. Despite the fact that small firms have a significant participation in the Brazilian economy, apparently they have a low capacity to innovate and compete in the global market.

This research project tackles this issue, focusing on the decision-making process of small firms regarding innovation. Studying "why" and "how" small Brazilian industrial firms make decisions leading to innovation, it was possible to deepen the knowledge of the innovation process, generating some hypotheses that may be helpful in managing such organizations.

The analysis of decision-making processes on innovation inevitably reveals a situation characterized by risk and uncertainty, which are concepts adopted by several areas of study, such as Economics, Business Administration, Psychology, Philosophy, Sociology, and others, either on a descriptive or on a prescriptive manner. Understanding how such concepts affect the decision-making process regarding innovation in small industrial firms has been the greatest challenge for this study.

This research, having an exploratory feature, was developed by means of a bibliographical survey and a study of multiple cases, involving five small chemical firms. One of the these was adopted as a pilot case and the others were used for replicating the research.

The comparative analysis of the cases reveals the main factors affecting the decisionmaking process in the small chemical firm, and allows speculations on possible decisionmaking models.
\end{abstract}




\section{SUMÁRIO}

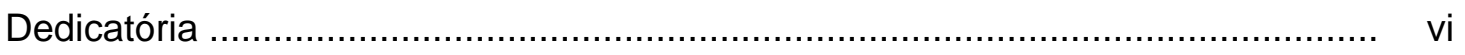

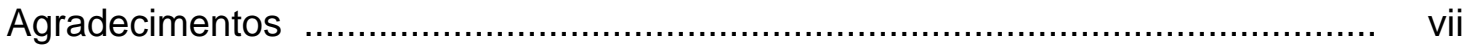

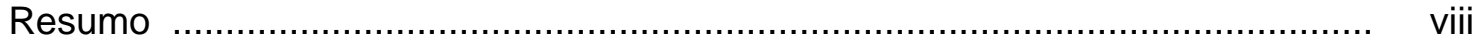

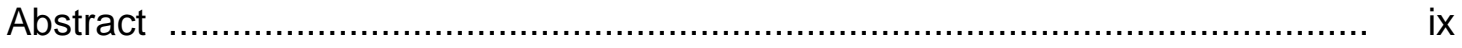

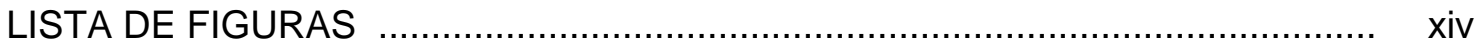

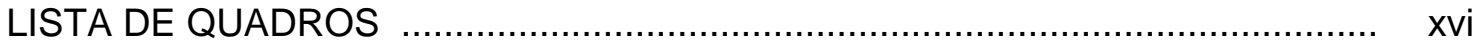

LISTA DE TABELAS .......................................................................... xviii

1 - INTRODUÇÃO

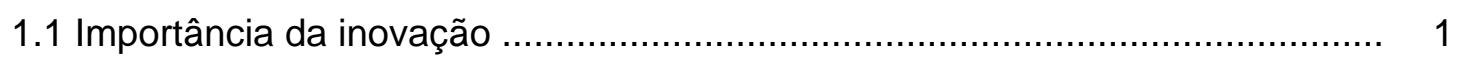

1.2 A pequena empresa e a inovação ........................................................ 3

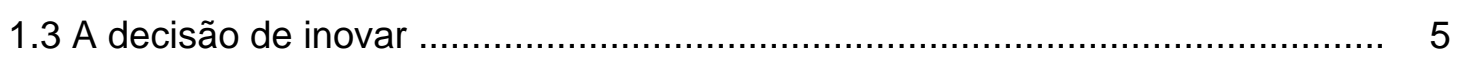

1.4 Objetivos desta pesquisa ............................................................. 7

1.5 Justificativas para realização da pesquisa ............................................... 8

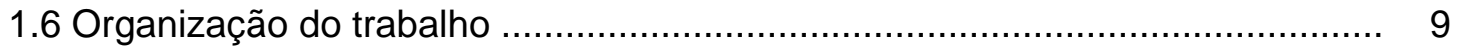

2 - FUNDAMENTAÇÃO TEÓRICA 10

2.1 Aspectos econômicos da inovação .......................................................... 12

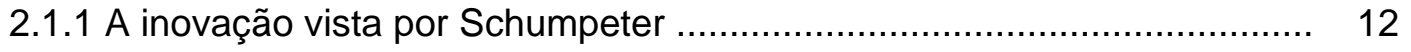

2.1.2 A teoria evolucionária da mudança econômica ...................................... 17

2.1.3 A inovação e o porte das empresas ................................................... 21

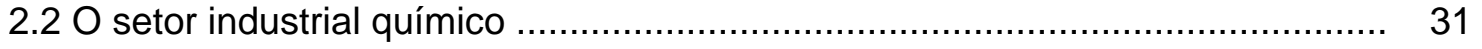

2.3 Características da pequena empresa ...................................................... 36

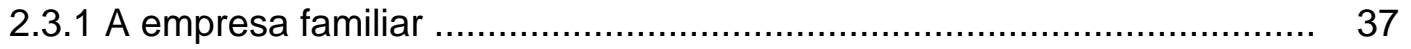

2.3.2 O empreendedor ................................................................... 38

2.3.3 A importância da pequena empresa .................................................. 41

$2.4 \mathrm{O}$ desenvolvimento de novos produtos e processos .................................. 44

2.4.1 A inovação como um processo estratégico ........................................ 48

2.4.2 O sucesso e o fracasso em inovações ............................................... 54

2.4.3 Tecnologia e custo da inovação ....................................................... 56 
2.4.4 O processo de inovação na pequena empresa .................................... 61

2.5 A tomada de decisão aplicada à administração da inovação .......................... 64

2.5.1 O risco e a incerteza na decisão ....................................................... 67

2.5.1.1 O constructo de risco ....................................................... 69

2.5.1.2 O paradigma do risco básico ................................................. 77

2.5.2 A percepção do risco ................................................................ 81

2.5.2.1 O processamento da informação ........................................... 81

2.5.2.2 Alguns fatores que influenciam a percepção ........................... 83

2.5.2.3 Heurísticas ............................................................. 86

2.5.3 A tolerância ao risco ....................................................................... 87

2.5.3.1 Como medir a tolerância ao risco .......................................... 88

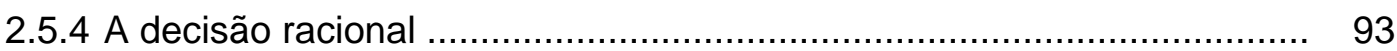

2.5.5 A qualidade da decisão .......................................................... 98

3 - METODOLOGIA DE PESQUISA $\quad 110$

3.1 A escolha da metodologia ................................................................. 110

3.2 Critério para seleção dos casos ........................................................... 113

3.2.1 Critério de classificação do porte da empresa ....................................... 114

3.2.1.1 Classificação por número de empregados .............................. 115

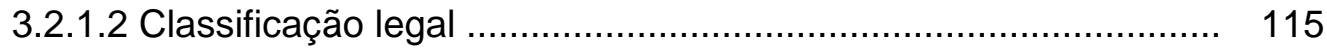

3.2.1.3 Outros critérios de classificação ............................................ 116

3.2.1.4 Critério adotado neste trabalho .......................................... 116

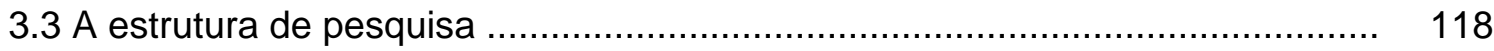

3.3.1 Questões do estudo ........................................................... 118

3.3.2 Proposição do estudo ................................................................... 118

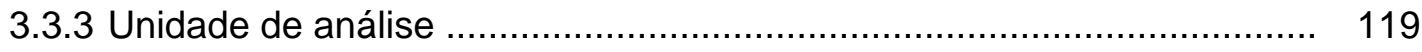

3.3.4 Ligação lógica entre os dados e a proposição

e critério de análise ....................................................................... 120

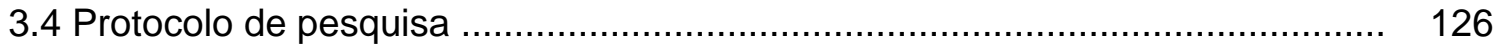

3.4.1 Etapas do estudo ................................................................... 126

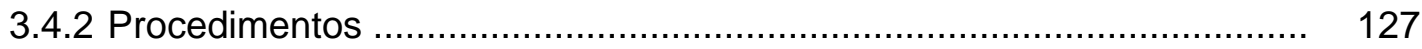

3.4.3 Instrumentos de pesquisa ....................................................... 128 


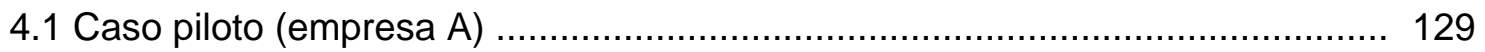

4.1.1 A história da empresa A .............................................................. 130

4.1.2 O mercado da empresa A ............................................................ 132

4.1.3 A administração da inovação na empresa A ........................................ 134

4.1.3.1 A inovação em serviços ......................................................... 137

4.1.4 A tomada de decisão na empresa A ............................................... 140

4.1.4.1 Percepção e tolerância ao risco na empresa A .......................... 144

4.2 Caso I (empresa B) ........................................................................ 145

4.2.1 A história da empresa B ............................................................ 145

4.2.2 O mercado da empresa B .......................................................... 146

4.2.3 A administração da inovação na empresa B ..................................... 147

4.2.4 A tomada de decisão na empresa B ............................................ 149

4.2.4.1 Percepção e tolerância ao risco na empresa B ........................... 152

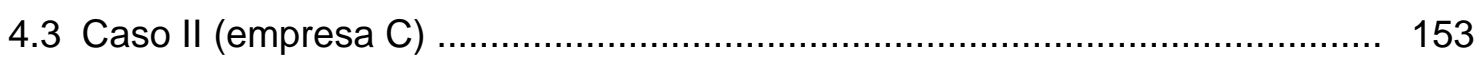

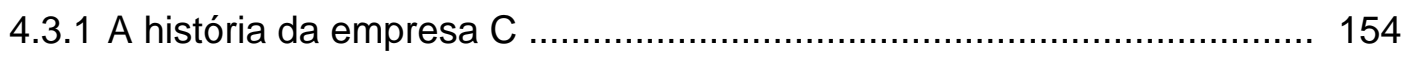

4.3.2 O mercado da empresa C .......................................................... 155

4.3.3 A administração da inovação na empresa C ....................................... 157

4.3.4 A tomada de decisão na empresa C ............................................. 159

4.3.4.1 Percepção e tolerância ao risco na empresa C ............................ 162

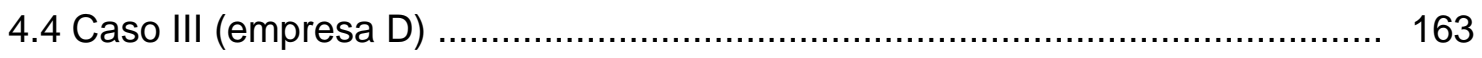

4.4.1 A história da empresa D ......................................................... 164

4.4.2 O mercado da empresa D .......................................................... 164

4.4.3 A administração da inovação na empresa D ........................................ 165

4.4.4 A tomada de decisão na empresa D ............................................. 168

4.4.4.1 Percepção e tolerância ao risco na empresa D ........................... 171

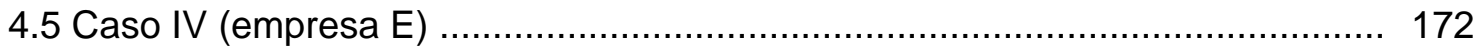

4.5.1 A história da empresa E ............................................................. 173

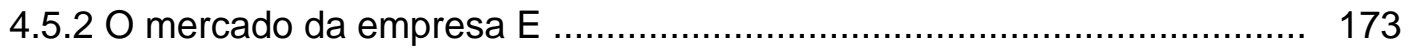

4.5.3 A administração da inovação na empresa E ...................................... 175

4.5.4 A tomada de decisão na empresa E ............................................. 177

4.5.4.1 Percepção e tolerância ao risco na empresa E .......................... 180

5 - ANÁLISE COMPARATIVA DOS CASOS 181

5.1 Análise do negócio e administração geral ................................................... 181 
5.2 Análise da administração da inovação .................................................... 190

5.3 Análise da tomada de decisão .................................................................. 197

5.4 Análise da percepção e tolerância ao risco .............................................. 202

6 - CONCLUSÕES 207

6.1 Conclusões do estudo sobre por que se decide inovar .............................. 207

6.1.1 Os fatores exógenos ............................................................... 208

6.1.2 Os fatores endógenos ........................................................... 209

6.1.3 A vontade pessoal dos decisores .............................................. 212

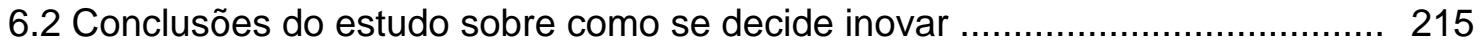

6.3 Conclusões do estudo sobre a proposição .............................................. 216

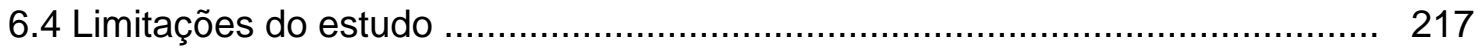

6.5 Sugestões para estudos futuros .......................................................... 218

$\begin{array}{ll}7 \text { - ANEXOS } & 219\end{array}$

8 - REFERÊNCIAS BIBLIOGRÁFICAS 228 


\section{LISTA DE FIGURAS}

1.1 Quem apresentou inovação tecnológica entre 1994 e 1996

2.1 Esquema das áreas de estudo 10

2.2 Faturamento gerado por produtos lançados no mercado nos últimos cinco anos (valores médios por empresa) ..................................... 30

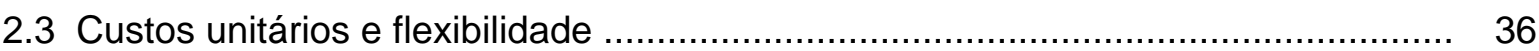

2.4 Extensão da inovação: "quanto nova é a inovação" ......................................... 48

2.5 Modelo de inovação de produto e processo ................................................... 49

2.6 Relação entre as inovações de produto e processo ......................................... 50

2.7 Rotinas que suportam o processo de administração da inovação ......................... 51

2.8 Estrutura para desenvolvimento da estratégia .................................................. 53

2.9 Modelo paralelo do processo de inovação tecnológica ...................................... 62

2.10 A estrutura pesquisa-inferência do pensamento ................................................. 64

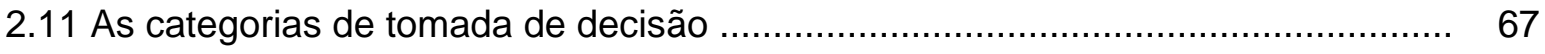

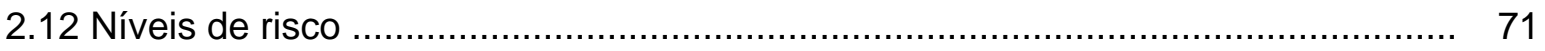

2.13 Alternativas da função valor para perdas ....................................................... 72

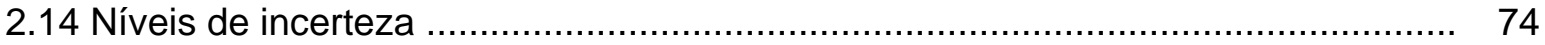

2.15 A decisão de modificar o produto ............................................................ 78

2.16 O paradigma do risco básico .................................................................. 79

2.17 Relação entre situação de risco e comportamento de risco ................................ 80

2.18 O modelo de processamento da informação de estimulações

paralelas (segundo Broadbent, 1956) …........................................................ 82

2.19 Árvore de decisão e EMV ............................................................................ 88

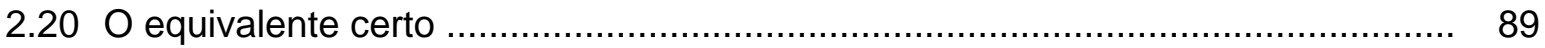

2.21 Função utilidade que demonstra aversão ao risco ........................................... 90

2.22 Formas diferentes da função utilidade ............................................................. 91

2.23 Função utilidade quando a riqueza aumenta .................................................. 91

2.24 Avaliação da tolerância ao risco ................................................................ 92

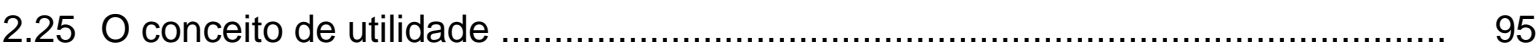


2.26 Uma curva hipotética da função valor na teoria da perspectiva 97

2.27 Peso da decisão hipotético de acordo com a teoria da perspectiva .................... 98

2.28 Fluxograma do processo de análise da decisão ........................................... 102

2.29 Fatores relevantes da qualidade de decisão ................................................... 107

3.1 Esquema do desenvolvimento da pesquisa ................................................... 112

3.2 Identificação da unidade de análise ......................................................... 119

3.3 A tomada de decisão em inovação .......................................................... 122

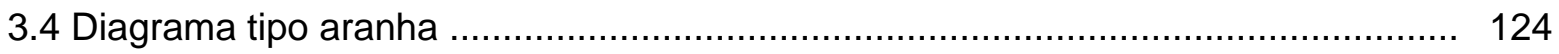

4.1 Processo de desenvolvimento de produto - empresa A ................................. 135

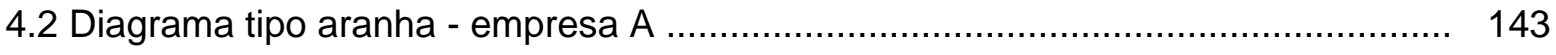

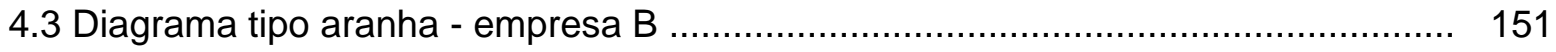

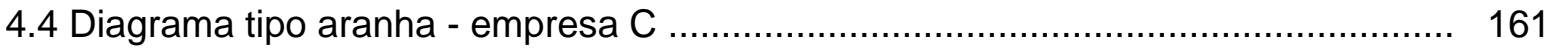

4.5 Processo de desenvolvimento de produto - empresa D .................................... 166

4.6 Diagrama tipo aranha - empresa D ........................................................... 170

4.7 Diagrama tipo aranha - empresa E ........................................................... 179

6.1 Matriz da relação entre qualidade e inovação ................................................... 211

6.2 Principais fatores na decisão de inovar .......................................................... 213 


\section{LISTA DE QUADROS}

2.1 Ondas sucessivas de mudança tecnológica ......................................................... 16

2.2 Características dos quatro segmentos de produtos petroquímicos ......................... 34

2.3 Grau de incerteza associada com vários tipos de inovação .................................. 46

2.4 Tipos de inovação: um esquema de classificação ................................................ 47

2.5 Classificação da tecnologia quanto ao grau de explicitação ................................. 57

2.6 As tarefas estratégicas da inovação na pequena e grande empresa ...................... 63

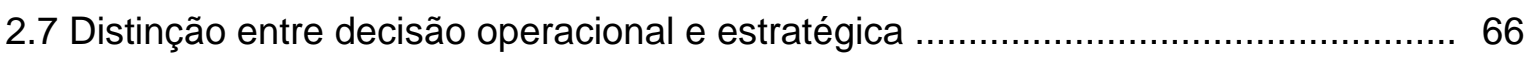

2.8 Resultado do experimento sobre expectativa ................................................... 85

2.9 Os elementos de uma decisão inteligente ..................................................... 101

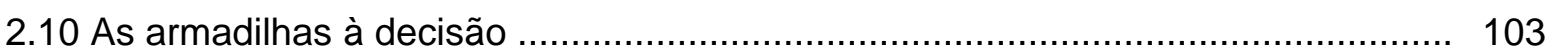

3.1 Resumo das questões de pesquisa e proposição do estudo ................................. 125

4.1 Resumo dos dados sobre inovação - empresa A …......................................... 139

4.2 Qualidade da tomada de decisão - empresa A ............................................... 141

4.3 Resumo dos dados sobre inovação - empresa B ............................................. 148

4.4 Qualidade da tomada de decisão - empresa B ............................................... 150

4.5 Resumo dos dados sobre inovação - empresa C …......................................... 158

4.6 Qualidade da tomada de decisão - empresa C .................................................... 160

4.7 Resumo dos dados sobre inovação - empresa D ................................................ 167

4.8 Qualidade da tomada de decisão - empresa D .................................................. 169

4.9 Resumo dos dados sobre inovação - empresa E ........................................... 176

4.10 Qualidade da tomada de decisão - empresa E ............................................ 178

5.1 Características do negócio das empresas ........................................................ 184

5.2 Característica geral das empresas ................................................................ 188

5.3 Resumo da atuação e resultado das empresas .................................................... 189

5.4 Visão das empresas sobre a importância da inovação .......................................... 190

5.5 Indicadores da importância da inovação ...................................................... 191 
5.6 Benefícios e dificuldades da inovação

192

5.7 O processo de inovação das empresas

5.8 Por que as empresas inovam 196

5.9 A racionalidade da decisão de inovar nas empresas 197

5.10 Consistência da racionalidade . 198

5.11 Processo de decisão das empresas 200

6.1 Processos de inovação na pequena indústria química 215 


\section{LISTA DE TABELAS}

1.1 As empresas líderes são mais inovadoras

2.1 Inovações nas indústrias do Reino Unido 1945 - 1983

2.2 Índices de inovações para grandes e pequenas empresas por

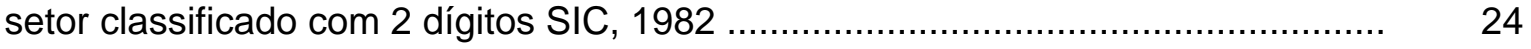

2.3 Faturamento da indústria química no Brasil ........................................................ 33

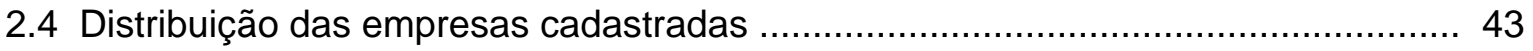

2.5 Dados da indústria de transformação ............................................................ 43

2.6 Decomposição do custo de inovação por tamanho de empresa ............................ 60

3.1 Classificação da empresa em alguns países da América Latina .......................... 115

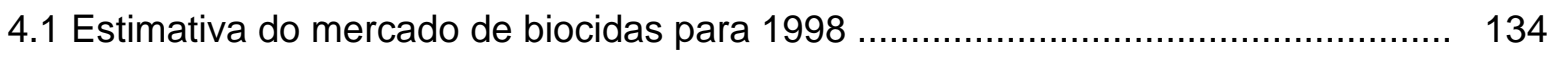

4.2 Resultado do teste de percepção do risco - empresa A .................................... 144

4.3 Resultado do teste de tolerância ao risco - empresa A ...................................... 144

4.4 Resultado do teste de percepção do risco - empresa B .................................... 152

4.5 Resultado do teste de tolerância ao risco - empresa B ....................................... 152

4.6 Resultado do teste de percepção do risco - empresa C ..................................... 162

4.7 Resultado do teste de tolerância ao risco - empresa C ...................................... 162

4.8 Resultado do teste de percepção do risco - empresa D .................................... 171

4.9 Resultado do teste de tolerância ao risco - empresa D ..................................... 171

4.10 Mercado de tintas e vernizes - Brasil ............................................................... 174

4.11 Resultado do teste de percepção do risco - empresa E ................................. 180

4.12 Resultado do teste de tolerância ao risco - empresa E ..................................... 180

5.1 Resultado da medição da qualidade de decisão ........................................... 201

5.2 Resultado do teste de percepção do risco

(probabilidade de fracasso) ................................................................... 203

5.3 Resultado do teste de tolerância ao risco (parâmetro R) ................................... 204

5.4 Resultado dos testes de percepção e tolerância ............................................ 205 


\section{CAPÍTULO 1}

\section{INTRODUÇÃO}

Durante o período compreendido entre o pós-guerra e o final da década de oitenta, as empresas buscaram desenvolver novas formas de gestão, objetivando aumentar a eficiência e a produtividade. Como resultado desse esforço surgiram diversas técnicas de grande utilidade para o gerenciamento da produção e operações. Segundo Matheson \& Matheson (1998), essas técnicas têm determinado uma substancial melhoria da qualidade, redução no tempo de ciclo da produção, redução de inventários e melhor serviço ao cliente.

O avanço da globalização das atividades econômicas tem sido uma das características dos anos noventa. A velocidade e a facilidade no transporte de pessoas, cargas e informações aumentaram significativamente nesta década, atingindo todos os países de economia aberta, em maior ou menor grau. Os efeitos dessas mudanças na tecnologia de transporte e comunicação são amplificados pela redução nas barreiras ao movimento de produtos e capitais (Milgrom e Roberts, 1992). As economias latinoamericanas, em particular, estarão submetidas a pressões crescentes para desregular os seus mercados, eliminando as tarifas alfandegárias e unificando o mercado financeiro, surgindo uma nova fase do desenvolvimento capitalista (Furtado, 1998).

No ambiente de intensa competição surgido na década de noventa, a eficiência e produtividade adquirem importância decisiva e deixam de ser um diferencial competitivo, para se tornarem condições necessárias para a sobrevivência das empresas. Assim, as empresas sobreviventes passam a competir em um novo patamar de eficácia, com novos fatores de diferenciação competitiva. A capacidade de inovar, segundo alguns pesquisadores, é o grande diferencial que emerge da organização industrial desta década. "As empresas alcançam vantagem competitiva através de ações de inovação" (Porter, 1998, p. 146)

\subsection{A importância da inovação}

A importância da inovação é justificada pela ação de três forças críticas: a intensa competição internacional, a sofisticação do mercado e a rápida mudança de tecnologias. Qualquer cadeia produtiva, desde as tecnicamente mais jovens e dinâmicas até as mais maduras e com ciclos de vida longos, sofrem a ação destas três forças (Clark \& Wheelwright, 1993). 
No mesmo sentido, Tidd \& Bessant \& Pavitt (1997) afirmam que, embora a vantagem competitiva possa advir de fatores como o tamanho ou posse de recursos, no modelo atual, está crescendo a supremacia daquelas organizações que podem mobilizar conhecimento, capacidade tecnológica e experiência para criar novos produtos, processos e serviços.

\begin{abstract}
"A pesquisa em administração tem sugerido que as empresas inovadoras aquelas que são capazes de usar inovação para diferenciar seus produtos $\overline{\mathrm{e}}$ serviços dos competidores_são, em média, duas vezes mais lucrativas que as outras empresas" (Tidd \& Bessant \& Pavitt, 1997, p.ix).
\end{abstract}

Para Zangwill (1993) , a inovação tem um papel decisivo na vida das empresas. De fato, citando uma pesquisa realizada com mais de uma centena de empresas, por Albert Page, em 1991 (tabela 1.1), o autor demonstra a existência de uma correlação direta entre o desempenho de uma empresa e sua habilidade em inovar. Essa afirmação é baseada na observação de que as empresas no topo da lista de liderança de diversos setores são as mais inovadoras.

\title{
Tabela 1.1 As empresas líderes são mais inovadoras
}

\begin{tabular}{lc}
\hline Posição da empresa no seu setor & $\begin{array}{c}\text { Porcentagem de vendas dos produtos } \\
\text { introduzidos nos últimos cinco anos }\end{array}$ \\
\hline Líder no setor & 49,1 \\
A terça parte superior do setor & 33,8 \\
A segunda terça parte do setor & 26,9 \\
A terça parte inferior do setor & 10,7
\end{tabular}

Fonte: Zangwill (1993) p. 2

A atividade inovadora é complexa e inerentemente envolvida com incerteza e risco. A idéia da inovação como um processo possível de ser administrado tem sido debatida por diversos pesquisadores, que vêm apresentando pontos de vista controvertidos. Alguns autores (tais como Reinertsen, 1997 e Robert, 1995) consideram que a maior parte dos processos de desenvolvimento é casual e não tem sido projetada de forma consciente. Por outro lado, alguns autores (Gold, 1971 e Schon, 1967, citados por Kay, 1979) demonstram evidências que sugerem a inovação como um processo racional ou apontam para essa possibilidade.

A pesquisa tem mostrado, principalmente nos Estados Unidos, que as pequenas empresas são responsáveis por um número significante de inovações básicas. Um alto grau de crescimento e de mudanças tecnológicas estão freqüentemente associados à atividade inovadora (Rothwell, 1983). 


\subsection{A pequena empresa e a inovação}

A importância da participação das micro e pequenas empresas na economia do Estado de São Paulo e por conseguinte na economia brasileira, pode ser observada pelos dados resultantes da pesquisa realizada pelo SEBRAE em 1997, (Cornelsen \& Henriques \& Susteras, 1998), onde as micro e pequenas empresas (MPEs) são responsáveis por:

- $97 \%$ dos estabelecimentos formais (comerciais, industriais e de serviços);

- $57 \%$ dos empregos gerados;

- $14 \%$ das indústrias e

- 30\% dos empregos gerados no setor industrial.

Apesar da significativa participação da pequena empresa na economia brasileira, aparentemente, essas empresas ainda apresentam uma baixa capacidade de inovar e competir no mercado globalizado. Soares (1994), com base em pesquisa realizada pelo Serviço de Apoio às Micro e Pequenas Empresas (SEBRAE), aponta que apenas 10\% das empresas brasileiras de pequeno porte realizam pesquisas sobre as expectativas do consumidor. Essa situação, segundo o autor, compromete o processo da introdução da inovação e a própria competitividade da empresa. As limitações financeiras e as deficiências gerenciais são citadas como as prováveis causas desta situação.

Outros estudos apontam as dificuldades da pequena empresa brasileira:

"Em decorrência do desempenho abaixo do esperado neste primeiro trimestre de 1998, cerca de $27 \%$ das MPE estão com seus pagamentos atrasados" (Avaliação trimestral do SEBRAE - SP).

"As empresas do estado de São Paulo produzem pouca tecnologia e entre elas as pequenas e médias são as que apresentaram menos inovações tecnológicas" (Fundação Sistema Estadual de Análise de Dados, Seade).

A figura 1.1 ilustra o resultado da pesquisa realizada pelo Seade em 1998, referente ao período de 1994 a 1996, com mais de dez mil empresas do Estado de São Paulo. 
Figura 1.1 Quem apresentou inovação tecnológica entre 1994 e 1996

(Em \% sobre o total de empresas)

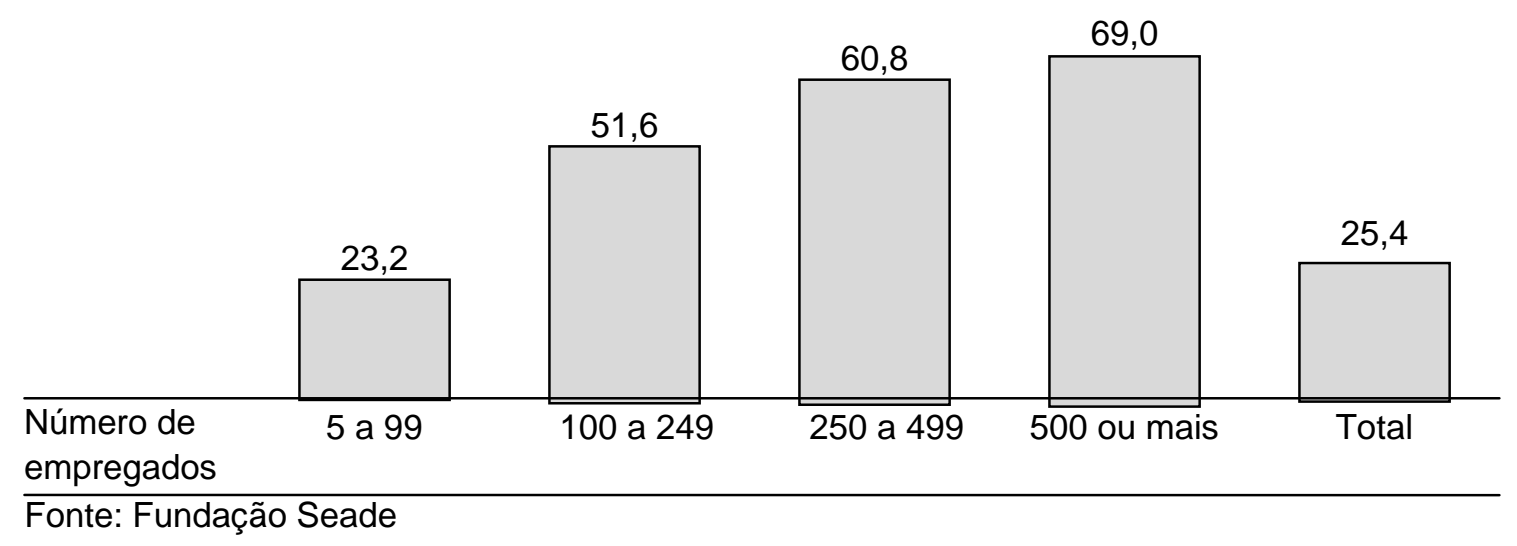

Até esse ponto, foi possível observar que: 1) a pequena empresa desempenha um importante papel na economia; 2) a inovação é um dos principais diferenciais competitivos no mundo atual; 3) as pequenas empresas brasileiras são pouco inovadoras e estão em dificuldades. Neste contexto, poder-se-ia aventar que a inovação é um campo praticamente restrito às grandes corporações ou às pequenas empresas de base tecnológica, mas não acessível às pequenas empresas tradicionais. Essa idéia é contestada por Rothwell (1993), que, para ilustrar o papel da pequena empresa tradicional, utiliza os seguintes argumentos:

- O sistema que melhor promove a mudança tecnológica é aquele que utiliza a simbiose potencial entre pequenas e grandes empresas.

- Os resultados de pesquisas mostrando a habilidade das pequenas empresas em produzir inovações radicais sugerem que em alguns setores industriais, as pequenas empresas têm uma participação desproporcionalmente maior que as grandes neste tipo de inovações.

- Com base no modelo de Abernathy e Utterbach ${ }^{1}$, durante a fase de introdução do produto no mercado, chamada de fase fluida, a pequena empresa tem melhores condições de atender os requisitos de grande taxa de inovações do produto e competição baseada na maximização do desempenho.

- De acordo com cálculos feitos pela Fundação Nacional da Ciência do Reino Unido, a pequena empresa apresenta um desempenho melhor que a grande quanto ao gasto em P\&D (Pesquisa e Desenvolvimento) por inovação desenvolvida.

Nessas condições, constata-se a existência de um grave problema para a economia brasileira: a falta de capacidade inovadora das pequenas empresas tradicionais.

${ }^{1}$ O modelo de inovação de produto e processo desenvolvido por Abernathy e Utterbach é apresentado em 2.4.1. 
Essa situação pode ser considerada ainda mais crítica se for levado em conta que a maioria das grandes empresas que atuam no mercado nacional não são de origem brasileira.

Possivelmente, uma atitude capaz de reverter tal situação, seja a participação intensiva da universidade na compreensão do problema e elaboração de propostas de solução, através de estudos e pesquisas com a pequena empresa brasileira. Infelizmente, conforme a observação de Kruglianskas (1996), parece que a academia ainda não despertou para esse caminho.

Embora seja amplamente reconhecida a importância da inovação tecnológica para a sobrevivência das empresas, [...] a disponibilidade de obras versando sobre o assunto, quando se trata de PMEs de setores tradicionais, é muito rara. Os empresários, bem como os estudiosos e executivos que atuam no campo da gestão deste tipo de empresa, se ressentem de referenciais conceituais e técnicos que possam orientar e subsidiar seu trabalho ( p. 5).

Assim, quando se considera as especificidades da administração de uma pequena empresa, aliadas à escassez de estudos sobre a inovação em empresas desse porte, podese supor que a administração dos seus processos de inovação esteja carecendo de informações para sua estruturação de forma competitiva.

\subsection{A decisão de inovar}

Alguns estudos e pesquisas sobre inovações, desenvolvidos fora do Brasil, podem fornecer algumas hipóteses para o caso brasileiro. Neste sentido, Clark \& Wheelwright (1993) observaram que, na maior parte das indústrias do Japão, Europa ou Estados Unidos, os executivos reconhecem que a área de desenvolvimento de novos produtos e processos ${ }^{2}$ (inovação) é aquela que oferece as maiores oportunidades e na qual as empresas precisam desenvolver suas capacidades. Da mesma forma, quando se verifica quais os principais temas que os alunos e professores das escolas de administração elegem como prioritários, a inovação surge no topo da lista. No entanto, não obstante se reconheça a importância fundamental da inovação, os resultados nas duas áreas ainda estão muito aquém do que se poderia esperar.

A partir da constatação de que a inovação é fundamental para a capacidade competitiva das empresas a longo prazo e que uma grande parte dos dirigentes dessas empresas tem consciência desse fato, por que os resultados são insatisfatórios ? A busca da resposta a essa questão tem levado vários acadêmicos a pesquisarem o assunto.

Uma das razões, segundo Matheson \& Matheson (1998), é que as decisões sobre pesquisa e desenvolvimento são complicadas, pois afetam todo o ambiente do negócio e são particularmente difíceis, devido às muitas incertezas que as cercam.

\footnotetext{
${ }^{2}$ Conforme abordado no item 2.4 deste trabalho, considera-se o desenvolvimento de novos produtos e processos como sinônimo de inovação.
} 
No mesmo sentido, Clemen (1996), verificou que a tomada de decisão, em qualquer área e em especial na área de inovação, pode se tornar uma tarefa bastante difícil, dependendo de quatro aspectos envolvidos na decisão, que são:

\section{- A própria complexidade do problema que envolve a decisão.}

Em alguns casos, o problema envolve os valores de diferentes grupos da sociedade, diversas alternativas de ação com suas incertezas e outros fatores que complicam a própria estruturação do problema. Em geral, as decisões estratégicas, como o desenvolvimento de um novo produto, envolvem muitas questões e diversas alternativas, o que torna a estrutura do problema complexa.

\section{- A incerteza inerente a uma tomada de decisão.}

Incerteza e risco tratam dos acontecimentos futuros e são tão mais difíceis de se prever, quanto maior o horizonte de tempo. A decisão do lançamento de um novo produto no mercado está relacionada com o tamanho do mercado, o preço, a competição, os custos de fabricação e distribuição. Todos esses fatores, com algum grau de incerteza e com impacto no resultado.

\section{- A existência de múltiplos objetivos, algumas vezes conflitantes.}

O decisor ${ }^{3}$ pode ter mais de um objetivo a ser alcançado com o resultado de uma questão e, eventualmente, o progresso em um sentido cria impedimentos para outros. Nessa situação, o decisor tem que escolher entre o benefício em uma área, contra os custos de outra ${ }^{4}$. No processo de desenvolvimento de novos produtos, em geral, surgem objetivos relacionados aos quesitos do produto, como qualidade e preço, que podem ser conflitantes com os objetivos da organização, como produtividade e custos.

\section{- Diferentes perspectivas do problema.}

Essa situação é mais comum, quando mais de uma pessoa participa do processo de decisão. No caso da tomada de decisão em inovação, é comum a participação das diversas áreas, tais como marketing, produção e engenharia.

\subsection{Objetivos desta pesquisa}

Esta pesquisa foi concebida a partir da convicção íntima do pesquisador nas argumentações apresentadas sobre a importância do papel das pequenas empresas na economia e da inovação como estratégia competitiva no mundo contemporâneo. Por outro lado, surge a inquietação em entender por que, no Brasil, aparentemente apenas um

\footnotetext{
${ }^{3}$ A expressão inglesa "decision maker" foi traduzida por decisor, no sentido de designar o agente decisório, conforme empregada por Bekman \& Costa Neto (1980), apesar de não ter sido encontrada em dicionários da língua portuguesa.

${ }^{4} \mathrm{Em}$ análise da decisão, essa situação é bastante freqüente e conhecida como "trade of'.
} 
número restrito de empresas de pequeno porte pratica a inovação de forma estratégica e sistemática.

A metodologia escolhida para aprofundar o entendimento das razões e das formas pelas quais a inovação ocorre dentro das pequenas empresas, foi o estudo de múltiplos casos. A unidade de análise, neste trabalho, foi a tomada de decisão que levou essas empresas à inovação.

Com o intuito de limitar o campo da pesquisa e facilitar a comparação entre as empresas, optou-se pelo desenvolvimento do estudo dentro de um único setor industrial, as pequenas indústrias químicas. A escolha do setor químico foi baseada nas informações sobre o desempenho desta indústria quanto às inovações, tanto no Brasil como no exterior. No Brasil, segundo a pesquisa realizada pelo SEBRAE em 1993, com 1057 micro e pequenas indústrias em todo o Brasil, a atividade química estava entre as quatro mais dinâmicas e com os melhores indicadores de competitividade. No Estados Unidos, a Small Business Administration (SBA), realizou uma pesquisa sobre 8074 inovações introduzidas no mercado em 1982, indicando que no setor químico, as pequenas empresas têm um índice de inovações por número de empregados superior às grandes empresas, conforme indicado na tabela 2.2 .

\section{Em resumo, os objetivos desta pesquisa são:}

1. Aprofundar o conhecimento sobre a tomada de decisão na administração da inovação em pequenas indústrias químicas, focando as duas questões de pesquisa : Por que e como se toma a decisão de desenvolver um novo produto ou processo?

2. Analisar a proposição: "A decisão de desenvolver um novo produto é tomada principalmente em função de: a) contexto no qual a indústria se insere; b) percepção do risco; c) tolerância ao risco do(s) decisor(s)". 


\subsection{Justificativas para realização da pesquisa}

As justificativas para a realização desta pesquisa estão relacionadas às seguintes observações:

\section{- Relevância do tema.}

A administração da inovação nas pequenas empresas brasileiras representa uma questão de suma importância para diversos setores da economia.

\section{- Levantamento de novas questões de pesquisa.}

Por se tratar de uma pesquisa qualitativa exploratória, abordando um tema ainda pouco estudado no contexto proposto, acredita-se que as novas questões apresentadas no capítulo 6 possam servir de base para novas pesquisas.

\section{- Contribuição aos administradores de pequenas empresas.}

$\mathrm{Na}$ medida do possível, pretende-se que o resultado desta pesquisa traga novas informações para a gestão das pequenas empresas e consiga alertar os seus administradores para a importância da tomada de decisão em inovação.

\section{- Contribuição à administração pública.}

Considerando a importância da inovação para o sucesso da pequena empresa e a participação desta na economia do país, pode-se inferir que estudos abordando esse campo, provavelmente, venham fornecer subsídios para estabelecimento de políticas públicas. 


\subsection{Organização do trabalho}

Esta dissertação foi organizada em oito capítulos, distribuídos de tal forma que a consulta e a compreensão do trabalho como um todo fique facilitada. O capítulo 1 apresenta uma visão geral do trabalho, seus objetivos e justificativas. Faz uma introdução aos principais assuntos que serão abordados nos capítulos seguintes.

O capítulo 2 reúne a fundamentação teórica do trabalho, com ênfase para os assuntos inovação e tomada de decisão, que constituem a base deste estudo. Esses dois assuntos apresentam características multidisciplinares. A administração da inovação tem sido estudada há mais tempo pelos economistas, desde Adam Smith, passando por Schumpeter e mais recentemente por Dosi, Freeman, Mansfield, Winter e tantos outros. Após a segunda grande guerra, o tema inovação passou a despertar a atenção de acadêmicos de outras áreas, tais como a engenharia e a administração. Abernathy, Clark, Utterback, Wheelwright e outros, fazem parte desse segundo grupo. Em 2.1_"Aspectos econômicos da inovação"_são apresentadas algumas das principais contribuições dos economistas; já os estudos sobre a administração da inovação são abordados em 2.4_"O desenvolvimento de produtos e processos".

O risco e a tomada de decisão, dois assuntos que estão fortemente interligados, são abordados em 2.5_"A tomada de decisão aplicada à administração". Além dos economistas, estudiosos de diversas áreas têm abordado os dois temas, com um enfoque prescritivo, como Howard, Matheson, Clemen e outros, ou com um enfoque descritivo, como empregado por diversos psicólogos e estudiosos do comportamento humano, como Kahneman, Fischhoff, Yates e outros.

Para completar a base teórica do estudo, foram incluídos alguns tópicos sobre as principais características da pequena empresa e do setor industrial químico.

No capítulo 3, por sua vez, é apresentada a metodologia empregada no planejamento da pesquisa e coleta das informações de cinco pequenas indústrias químicas. Quanto à descrição dos casos e os dados coletados, bem como a análise comparativa desses casos, são apresentadas nos capítulos 4 e 5.

As conclusões deste trabalho são apresentadas no capítulo 6.

O capítulo 7 contém os anexos da dissertação, composto dos roteiros de entrevistas e modelo de testes aplicados. Finalmente, o capítulo 8 trata da referência bibliográfica. 


\section{CAPÍTULO 2}

\section{FUNDAMENTAÇÃO TEÓRICA}

A fundamentação teórica desta pesquisa foi desenvolvida procurando abranger os campos de estudo que estão diretamente relacionados com a tomada de decisão no desenvolvimento de novos produtos e processos na pequena empresa industrial química. $O$ quadro 2.1 apresenta um esquema das áreas de estudo que se pretende abordar.

Figura 2.1 Esquema das áreas de estudo

AMBIENTE EXTERNO (aspectos econômicos sobre a inovação)

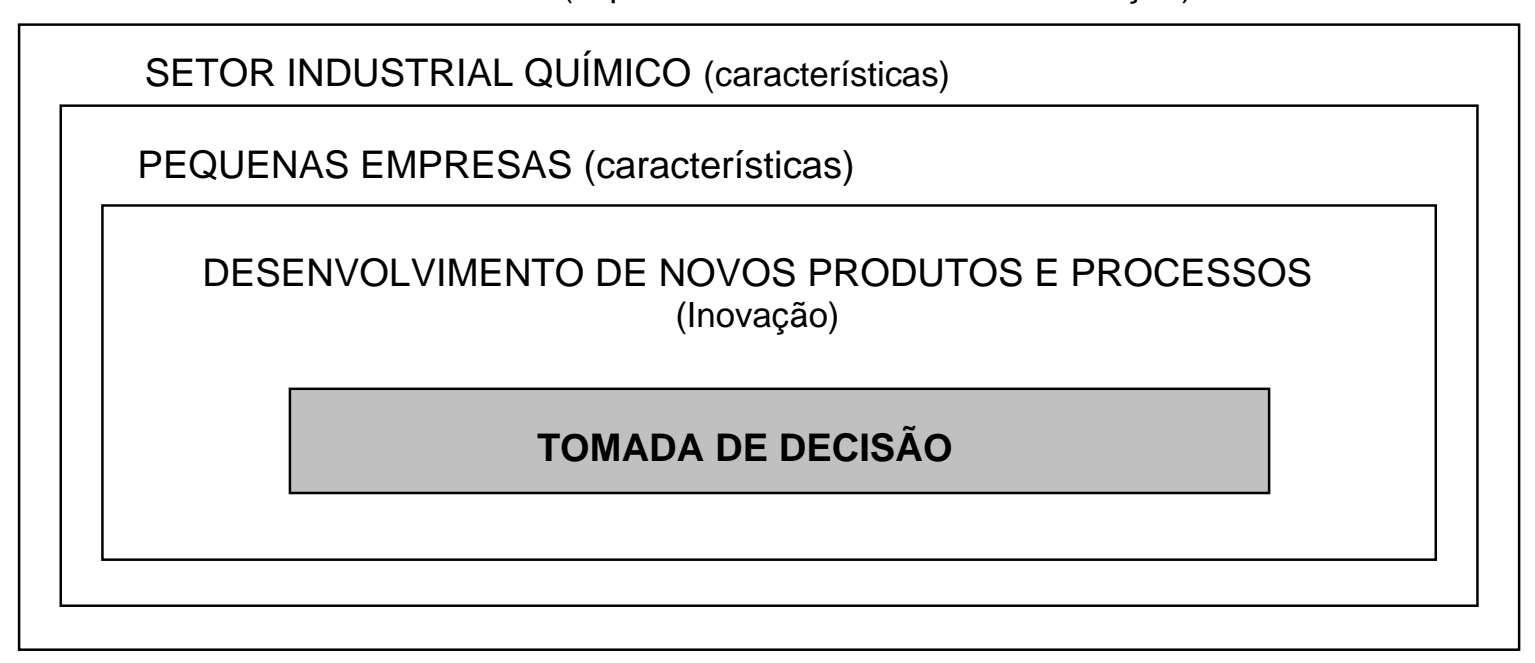

O foco desta pesquisa é a tomada de decisão estratégica na administração do desenvolvimento de novos produtos e processos. A administração da inovação, conforme ressaltado por Tidd \& Bessant \& Pavitt (1997), é um tema multidisciplinar que interage com o meio ambiente; por esse motivo achou-se conveniente a inclusão do estudo de aspectos econômicos na fundamentação teórica.

A escolha do setor químico deveu-se ao fato desse setor apresentar um índice elevado ${ }^{5}$ de indústrias inovadoras. Ao mesmo tempo, foram consideradas as vantagens de se limitar o estudo dentro de um único setor, eliminando-se fatores de influência inter e intra-

\footnotetext{
${ }^{5}$ Conforme pesquisa realizada pelo Small Business Administration, SBA, o setor químico encontra-se entre aqueles onde a pequena indústria é mais inovadora. O resultado dessa pesquisa é apresentado na tabela 2.2.
} 
indústrias, diferenciados no estudo das empresas. Dentro do setor químico, elegeu-se o conjunto das pequenas empresas industriais como alvo da pesquisa. Finalmente, pretendeuse pesquisar com mais profundidade a tomada de decisão estratégica no desenvolvimento de novos produtos e processos.

Para facilitar a compreensão, a fundamentação teórica foi organizada da seguinte forma:

2.1 Aspectos econômicos da inovação;

2.2 O setor industrial químico;

2.3 Características da pequena empresa

2.4 O desenvolvimento de novos produtos e processos;

2.5 A tomada de decisão aplicada à administração da inovação. 


\subsection{Aspectos econômicos da inovação}

Segundo Samuelson \& Nordhaus (1993), o processo do desenvolvimento econômico está relacionado diretamente a quatro fatores fundamentais: os recursos humanos, os recursos naturais, a formação de capital (interno e importado) e a tecnologia.

O desenvolvimento econômico e a inovação têm sido objeto de reflexão para os economistas há pelo menos duzentos anos, considerando-se como marco inicial os estudos de Adam Smith sobre melhoria das máquinas e a forma com que a divisão do trabalho promoveria invenções especializadas. Posteriormente, Karl Marx observou a questão do desenvolvimento tecnológico ao considerar que as inovações técnicas exerceriam um papel preponderante no seu modelo da economia capitalista. Com Schumpeter, no início deste século, foi novamente ressaltada a importância do papel das mudanças tecnológicas no desenvolvimento econômico. Após a segunda guerra mundial, os Estados Unidos e em particular os economistas americanos voltaram suas atenções para a questão do desenvolvimento econômico, mas ainda assim, concentrados nos insumos tradicionais, o capital e a mão-de-obra. Mudança tecnológica, educação, administração, importantes fatores do desenvolvimento, permaneceram ainda como assunto secundário. Apenas recentemente, com os estudos de econometria sobre o crescimento nos países desenvolvidos, é que se passou a dar mais atenção às mudanças tecnológicas de forma analítica e sistemática (Freeman \& Soete, 1997).

\subsubsection{A inovação vista por Schumpeter}

No início deste século, surgiu uma nova visão do desenvolvimento econômico e da inovação com a obra de Joseph A. Schumpeter ${ }^{6}$.

Schumpeter (1961), ao desenvolver a sua teoria do desenvolvimento econômico, separava a análise em duas situações distintas, que mereciam tratamentos diferenciados. A primeira situação trouxe uma análise voltada para o fluxo circular da vida econômica, com um modelo estático, onde a atividade humana se apresenta de maneira idêntica em sua essência, repetindo-se indefinidamente. A outra situação, ao contrário, representa um modelo dinâmico da economia, onde ocorrem as transformações geradoras do desenvolvimento econômico.

Para demarcar de forma clara as duas concepções, Schumpeter utilizou três pares de antagonismos correspondentes:

\footnotetext{
${ }^{6}$ Em 1908, Schumpeter publicou "A natureza e a essência da economia política teórica" e em 1912, o livro "Teoria do desenvolvimento econômico" , no original "Theorie der wirtschaftlichen entwicklung".
} 


\title{
1) Pela oposição de dois processos reais
}

\author{
Fluxo circulatório ou tendência \\ ao equilíbrio \\ $\mathrm{X}$
}

2) Antagonismo de duas aparelhagens teóricas

Estática $\quad \mathrm{X} \quad$ Dinâmica

\section{3) Contraposição de dois tipos de comportamento}

\section{Gerentes $\quad \mathrm{X} \quad$ Empreendedores}

Produzir significa combinar materiais e forças disponíveis com o objetivo determinado pelo sistema econômico. A tecnologia só desenvolve métodos de produção para utilidades requeridas ou, em outras palavras, a lógica econômica prevalece sobre a técnica. O desenvolvimento, diferente do crescimento, se define como o levar avante novas combinações de produção, que abrangem os cinco casos seguintes:

1) A aceitação de um novo bem, ou seja, um bem ainda não familiar ao consumidor;

2) A adoção de um novo método de produção;

3) A abertura de um novo mercado;

4) A conquista de nova fonte de suprimento dos insumos;

5) A reorganização de qualquer indústria.

Realizar novas combinações significa, simplesmente, o emprego diferente dos insumos de produção existentes no mercado, embora possa ocorrer, até com uma certa freqüência, o emprego de meios inusitados. Ao empreendimento de novas combinações denominou-se empresa e o indivíduo responsável pela sua realização, empreendedor. Nessa concepção apresentada, emitiu diversos conceitos, tais como:

- As novas combinações, em geral, não surgem das antigas, mas começam a produzir paralelamente a essas. "Não é o proprietário da diligência quem constrói as ferrovias" (p. 94).

- O empreendimento de novas combinações é uma função especial e constitui privilégio de um pequeno número de pessoas. Os empreendedores representam a força motriz de um grande número de fenômenos importantes.

- As invenções, enquanto não são postas em prática, são irrelevantes para a economia. Efetuar qualquer progresso é obra totalmente diferente de inventá-lo e que exige aptidões diferentes. As inovações efetuadas pelos empreendedores 
não precisam, absolutamente, serem invenções. Nesse sentido, Freeman \& Soete (1997) comentam:

Nós devemos a Schumpeter a distinção, extremamente importante, entre invenções e inovações, a qual tem sido desde então, geralmente incorporada à teoria econômica. Uma invenção é uma idéia, um esboço ou modelo para um novo ou melhorado aparelho, produto, processo ou sistema. Invenções, assim, podem normalmente (não sempre) ser patenteadas, mas elas não necessariamente se tornam inovações técnicas. De fato, a maior parte não se torna. Uma inovação, no sentido econômico, é consumada somente com a primeira transação comercial, envolvendo o novo produto, processo, sistema ou aparelho, apesar de que a palavra é usada também para descrever o processo todo. Naturalmente, novas invenções surgem durante o processo de inovação, e ainda mais invenções e inovações podem ser feitas durante o processo de difusão. Contudo, a distinção conceitual de Schumpeter é valiosa (p. 6).

- "Em todos os casos, o sentido da ação econômica é a satisfação de necessidades, na acepção de que absolutamente não haveria ação econômica, se não houvesse desejos ou necessidades" (Schumpeter, 1961, p. 125).

O argumento central para considerar o empreendedor e a sua ação tão especial é apresentado na forma de uma analogia com o desenvolvimento incremental do conhecimento humano. Nesse sentido, observa-se que a mínima ação cotidiana exigiria esforços gigantescos do indivíduo se todo o conhecimento ou hábito tivesse que ser renovado e conscientemente reproduzido. Ao contrário, as funções da rotina diária e até a função de dirigir pessoas (sic), pode ser preenchida por qualquer pessoa normal; o conhecimento necessário submerge no stratum do subconsciente. De forma análoga, isso se aplica à vida econômica ordinária.

Para Schumpeter, cada passo fora dos limites da rotina apresenta dificuldades, cuja natureza pode ser expressa pelos seguintes pontos:

\section{1) Dificuldade na tomada de decisão}

Fora dos trâmites costumeiros, o indivíduo fica sem os dados para decidir e sem as normas de conduta que geralmente conhece. Precisa realizar o que a tradição faz por ele na vida diária. O que já foi executado tem a realidade profundamente marcante de tudo o que foi visto e experimentado; a novidade é apenas ficção da idéia. O bom êxito de tudo depende da intuição, da capacidade de enxergar as coisas e de perceber o fato essencial, afastando-se dos não essenciais. Quanto mais acuradamente se aprender a conhecer o ambiente social e natural, tanto mais perfeito tornar-se-á o controle dos fatos. 


\section{2) Psique do homem de negócio}

Os indivíduos manifestam uma certa relutância contra as coisas novas e demonstrariam essa resistência mesmo se as dificuldades objetivas não existissem. O pensamento retorna sempre à trilha costumeira, ainda que esta se haja tornado inadequada e inovações mais convenientes não apresentem, em si mesmas, qualquer dificuldade específica.

\section{3) Reação do meio ambiente social}

Essa reação se manifesta de diversas formas, sendo muito comum, na existência de impedimentos legais e políticos. No campo econômico, essa resistência se manifesta, antes de tudo, nos grupos ameaçados pela inovação; depois na dificuldade de encontrar a colaboração necessária e finalmente, na dificuldade de conquistar consumidores.

Uma contribuição importante da obra de Schumpeter foi a explicação de um fenômeno observado anteriormente pelo economista russo Kondratieff sobre o movimento cíclico $^{7}$ do desenvolvimento econômico. Segundo Schumpeter, a economia passa por longas fases de desenvolvimento, que duram por volta de cinqüenta anos, descrita por ele como sucessivas revoluções industriais provocados pela introdução de novas tecnologias. Cada ciclo da economia era único, devido sobretudo à variedade de inovações técnicas, mas também por causa de outros fatores históricos, como as guerras. O quadro 2.1 apresenta as fases de desenvolvimento nos últimos duzentos anos.

\footnotetext{
${ }^{7}$ Segundo Freeman \& Soete (1997), os economistas preferem a denominação onda ou fase ao invés de ciclo, que daria um caráter determinístico a um fenômeno impreciso.
} 


\section{Quadro 2.1 Ondas sucessivas de mudança tecnológica}

\begin{tabular}{|c|c|c|c|c|c|}
\hline \multicolumn{2}{|c|}{ Ondas longas ou ciclos } & \multirow[b]{2}{*}{$\begin{array}{l}\text { Ciência, tecnologia, } \\
\text { educação e treinamento }\end{array}$} & \multicolumn{2}{|c|}{$\begin{array}{c}\text { Aspectos da } \\
\text { infraestrutura dominante }\end{array}$} & \multirow[b]{2}{*}{$\begin{array}{l}\text { Fatores chave } \\
\text { universais e } \\
\text { acessíveis }\end{array}$} \\
\hline $\begin{array}{l}\text { Tempo } \\
\text { aprox. }\end{array}$ & $\begin{array}{l}\text { Ondas de } \\
\text { Kondratieff }\end{array}$ & & $\begin{array}{l}\text { Transporte } \\
\text { Comunicação }\end{array}$ & $\begin{array}{l}\text { Sistemas } \\
\text { de energia }\end{array}$ & \\
\hline $\begin{array}{l}\text { Primeira } \\
\text { 1780s - 1840s }\end{array}$ & $\begin{array}{l}\text { Revolução } \\
\text { industrial: } \\
\text { produção fabril } \\
\text { para têxteis }\end{array}$ & $\begin{array}{l}\text { Auto-aprendizado, } \\
\text { aprender fazendo, } \\
\text { discordâncias acadêmicas, } \\
\text { sociedades científicas }\end{array}$ & $\begin{array}{l}\text { Canais, } \\
\text { estradas } \\
\text { para } \\
\text { carruagens }\end{array}$ & $\begin{array}{l}\text { Energia } \\
\text { gerada pelo } \\
\text { movimento } \\
\text { d'água }\end{array}$ & Algodão \\
\hline $\begin{array}{l}\text { Segunda } \\
\text { 1840s-1890s }\end{array}$ & $\begin{array}{l}\text { Era da máquina } \\
\text { vapor e ferrovias }\end{array}$ & $\begin{array}{l}\text { Engenheiros mecânicos } \\
\text { e civis profissionais, } \\
\text { Institutos de tecnologia, } \\
\text { educação primária em massa }\end{array}$ & $\begin{array}{l}\text { Ferrovias } \\
\text { (ferro), } \\
\text { telégrafo } \\
\text { a }\end{array}$ & $\begin{array}{l}\text { Energia } \\
\text { vapor }\end{array}$ & Carvão, ferro \\
\hline $\begin{array}{l}\text { Terceira } \\
\text { 1890s - 1940s }\end{array}$ & $\begin{array}{l}\text { Era da } \\
\text { eletricidade } \\
\text { e do aço }\end{array}$ & $\begin{array}{l}\text { Laboratórios de P\&D } \\
\text { industrial, químicos e } \\
\text { elétricos, laboratórios } \\
\text { nacionais e de normas }\end{array}$ & $\begin{array}{l}\text { Ferrovias } \\
\text { (aço), } \\
\text { telefone }\end{array}$ & Eletricidade & Aço \\
\hline $\begin{array}{l}\text { Quarta } \\
\text { 1940s-1990s }\end{array}$ & $\begin{array}{l}\text { Era da produção } \\
\text { em massa de automóvei } \\
\text { e materiais sintéticos }\end{array}$ & $\begin{array}{l}\text { P\&D em larga escala } \\
\text { industrial e de } \\
\text { sgoverno, educação } \\
\text { média em massa }\end{array}$ & $\begin{array}{l}\text { Rodovias, } \\
\text { rádio e TV, } \\
\text { transporte } \\
\text { aéreo }\end{array}$ & Petróleo & $\begin{array}{l}\text { Petróleo, } \\
\text { plásticos }\end{array}$ \\
\hline $\begin{array}{l}\text { Quinta } \\
\text { 1990s - ? }\end{array}$ & $\begin{array}{l}\text { Era da microeletrônica } \\
\text { e redes de computador }\end{array}$ & $\begin{array}{l}\text { Redes de dados, P\&D } \\
\text { em redes globais, educação } \\
\text { contínua e treinamento }\end{array}$ & $\begin{array}{l}\text { Infovias, } \\
\text { redes } \\
\text { digitais }\end{array}$ & $\begin{array}{l}\text { Gás/ } \\
\text { petróleo }\end{array}$ & $\begin{array}{l}\text { Micro- } \\
\text { eletrônicos }\end{array}$ \\
\hline
\end{tabular}

Fonte: Freeman \& Soete (1997) p. 19

Schumpeter dedicou-se, na maior parte da sua obra, a ressaltar o importante papel do empreendedor no processo de inovação e apenas no final dela é que se rendeu à idéia do desenvolvimento tecnológico dentro dos laboratórios de pesquisa das grandes corporações. Em 1928, chegou a publicar um artigo onde apontava a administração burocrática da inovação como substituta do talento individual e principal veículo para a inovação técnica na economia. 


\subsubsection{A teoria evolucionária da mudança econômica}

Tomando emprestadas as idéias básicas da biologia, Richard R. Nelson e Sidney G. Winter, elaboraram uma teoria para a mudança econômica, que foi publicada em 1982, no livro "An evolutionary theory of economic change" (Nelson \& Winter, 1996)

A teoria evolucionária adota duas premissas básicas: 1) a mudança econômica é importante e interessante; 2) as empresas são tratadas como motivadas por lucro e engajadas na busca de meios para aumentá-lo, mas suas ações não são assumidas como a escolha maximizante do lucro sobre um dado conjunto de alternativas. A primeira premissa é a motivação do estudo, enquanto a segunda é uma das críticas que os autores fazem à teoria econômica ortodoxa ${ }^{8}$.

No modelo econômico ortodoxo, as empresas são vistas como operando com um conjunto de regras de decisão que determinam suas ações em função das condições externas (mercado) e internas (como o estoque de capital disponível). Essas regras refletem o comportamento maximizante das empresas, que pode ser separado em três componentes:

1) Há uma especificação do que as empresas, dentro de um setor, estão procurando maximizar; em geral, é lucro ou valor presente, mas em alguns casos é algo diferente;

2) Há uma especificação de um conjunto de coisas que as empresas sabem como fazer;

3) Há uma presunção que a ação da empresa pode ser vista como o resultado da escolha que maximiza o grau no qual o seu objetivo é alcançado, uma vez dado seu conjunto de alternativas, as restrições do mercado e talvez outras restrições internas.

Outro pilar estrutural dos modelos econômicos ortodoxos é o conceito de equilíbrio, onde o exemplo mais básico são as curvas da oferta e demanda de um mercado. Essas curvas são as simples agregações das regras de comportamento dos vendedores e compradores individuais. A teoria econômica ortodoxa aborda a questão da mudança da demanda de um produto ou do preço de um fator de operação, assumindo que os ajustes de comportamento são instantâneos e que essas mudanças nas condições de mercado e o resultante equilíbrio de preços são perfeita e antecipadamente previstos por todos. Na observação dos autores, não é isso que ocorre, as empresas levam algum tempo para responder às condições do mercado e não podem ser vistas como agentes

\footnotetext{
${ }^{8}$ Neste caso, a teoria ortodoxa representa a formalização e interpretação moderna do pensamento ocidental econômico, traçado desde Smith e Ricardo, passando por Marshall e Walras.
} 
maximizantes. Nesse sentido, os autores acreditam que a teoria ortodoxa econômica tende a tratar a questão da mudança de forma forçada e praticamente ignorando a inovação. Como uma teoria da empresa e do comportamento da indústria, deveria estar preocupada com o fenômeno da mudança e com a inovação e suas conseqüências.

A idéia central na teoria evolucionária da mudança econômica, que foi emprestada da biologia, é a da seleção natural econômica. De acordo com tal conceito, o ambiente de mercado provê uma definição de sucesso ou fracasso para as empresas, baseado na sua habilidade de sobreviver e crescer. Existe uma "genética organizacional" responsável pelo processo no qual as características das organizações, incluindo aquelas que explicam a habilidade em produzir resultados e realizar lucros, são transmitidas através do tempo.

A conotação mais ampla do termo "evolucionária" inclui a preocupação com processos de longo prazo e mudança progressiva. As regularidades observadas na realidade presente não são interpretadas como uma solução para um problema estático, mas como o resultado de processos dinâmicos ocorridos no passado. Em outras palavras, a condição da indústria em cada período de tempo fornece a semente da sua condição no período seguinte. É exatamente na caracterização da transição de um período para o próximo que o principal compromisso teórico da teoria evolucionária tem aplicação direta. Esse compromisso inclui a idéia de que o processo não é determinístico, ao contrário, a condição da indústria em um período determina a distribuição de probabilidade da sua condição no período seguinte.

Tanto na teoria econômica ortodoxa como na evolucionária, as regras de decisão formam o conceito operacional básico, entretanto, enquanto a teoria ortodoxa adota a noção de comportamento maximizante para explicar o porquê das regras de decisão serem o que são, a teoria evolucionária utiliza o conceito de rotina.

Como uma primeira aproximação, pode-se esperar que o comportamento das empresas no futuro estará de acordo com as rotinas que elas utilizaram no passado. Isso não implica uma identidade literal de comportamento ao longo do tempo, uma vez que as rotinas podem responder de forma complexa aos sinais do ambiente. Isso implica que é um tanto inadequado conceber o comportamento de uma empresa em termos de escolha deliberada a partir de um extenso cardápio de alternativas, que algum observador externo considere como oportunidades disponíveis para a organização. O cardápio não é extenso, é estreito e idiossincrático; ele é construído com as rotinas da empresa, e a maior parte das "escolhas" também é realizada automaticamente por essas rotinas. Isso não significa que uma empresa não possa ser um sucesso por um curto ou longo período: sucesso e fracasso dependem do estado do ambiente. (Nelson \& Winter, 1996, p. 134)

A realidade do funcionamento das organizações e no centro dela a rotina, formam a fundação da teoria econômica evolucionária. Rotina é o termo geral utilizado para exprimir todo comportamento regular e previsível das empresas. Tal termo é usado para caracterizar 
as atividades da empresa, que vão desde as bem especificadas rotinas técnicas para produzir coisas, até as políticas para investimento, pesquisa e desenvolvimento. Na teoria evolucionária, as rotinas desempenham o mesmo papel que os genes têm na teoria evolucionária biológica, como um traço persistente do organismo que determina suas possíveis características.

Nem todo comportamento no mundo dos negócios está dentro do conceito de rotina. Ao contrário, a teoria evolucionária admite que a maior parte das decisões de negócios que são da mais alta importância, tanto do ponto de vista da empresa como da sociedade, em geral, não são do tipo rotinas. O fato de que nem todos os comportamentos em negócios seguem um caminho regular e previsível é acomodado na teoria pelo reconhecimento de que existem elementos estocásticos, tanto na determinação das decisões, como no resultado dessas decisões.

As rotinas de uma empresa definem uma lista de funções, que por sua vez determinam o que a empresa faz, considerando as diversas variáveis externas (principalmente condições do mercado) e variáveis do estado interno.

A teoria evolucionária distingue três classes de rotinas:

a) As rotinas relacionadas com as ações da empresa em qualquer tempo, dado o seu estoque de capital (equipamentos e outros fatores de produção que não podem ser aumentados no curto prazo). Essas rotinas são chamadas de "características de operação";

b) As que determinam o aumento ou diminuição do estoque de capital;

c) As que operam para modificar, ao longo do tempo, vários aspectos das características de operação.

Para a teoria evolucionária, o comportamento de uma organização é, num sentido limitado mas importante, redutível ao comportamento dos indivíduos que são membros desta organização, o que vai se somar à idéia de que os indivíduos também são organizações complexas. Nesse aspecto, a teoria propõe que as habilidades individuais são análogas às rotinas organizacionais, sendo possível compreender o papel da rotina no funcionamento da organização através da compreensão do papel que a habilidade tem no funcionamento dos indivíduos.

A visão do comportamento organizacional na teoria evolucionária foi moldada a partir das idéias de diversos economistas e teóricos da organização, tais como Schumpeter, Williamson e outros. Enquanto a teoria ortodoxa considera o comportamento organizacional como a escolha ótima de um conjunto de capacidades bem definido, a teoria evolucionária 
elege o conceito de rotina como um ponto chave na estrutura teórica aplicada às organizações.

A habilidade individual é definida como a capacidade para uma seqüência regular de comportamentos coordenados, a qual normalmente é eficaz em relação aos seus objetivos, dado o contexto em que ela ocorre. Para se entender melhor o conceito de habilidade, os autores enfatizam que ela tem muitas características em comum com a escolha de comportamento, argumentando: 1) a habilidade é possível de ser programada, uma vez que envolve uma seqüência de etapas, sendo cada etapa sucessiva, passível de ser acionada pela precedente, completando-a; 2) o conhecimento que explica o desempenho de uma pessoa hábil é, em grande parte, um conhecimento tácito, no sentido de que a pessoa não está perfeitamente consciente dos detalhes do desempenho e acha difícil ou impossível articular uma contagem completa desses detalhes; 3) o exercício da habilidade, muitas vezes, envolve a execução de numerosas escolhas, mas em geral, as opções são selecionadas automaticamente e sem a consciência de que uma escolha esteja sendo feita.

A rotina exerce um papel de memória organizacional. Assim, é argumentado que o fato de transformar uma atividade em uma rotina, constitui a mais importante forma de estocagem de um conhecimento operacional específico da organização. A memória nas organizações é ativada através do "fazer", da mesma forma que uma pessoa lembra a habilidade, exercitando-a. Embora os registros sejam importantes para as organizações, a memória é ativada principalmente pelo exercício e não pode ser garantida totalmente pelos registros escritos ou de qualquer outra forma.

A coordenação das atividades, na teoria evolucionária, é o fator central para o bom desempenho produtivo da organização. Nesse caso, a coordenação será eficaz à medida que seus membros, individualmente, conhecendo seu trabalho, interpretem e respondam corretamente as mensagens recebidas. A informação é armazenada, em primeiro lugar na memória dos membros da organização, na qual reside todo o conhecimento articulável ou tácito, que por sua vez constituem as habilidades individuais e rotinas organizacionais. Desse modo, considerando que a memória dos membros armazena a maior parte das informações necessárias para o desempenho das rotinas organizacionais, existe uma verdade substancial na proposição de que o conhecimento que uma organização possui é redutível ao conhecimento dos seus membros.

Os conceitos de rotina e inovação são vistos na teoria evolucionária como idéias opostas. A inovação implica a mudança de rotina ou novas combinações de rotinas 
existentes. Por isso, a teoria evolucionária corrobora a forma como Schumpeter identificava a inovação: "levar adiante novas combinações".

$\mathrm{Na}$ teoria evolucionária, a incerteza fundamental que cerca a atividade inovadora é a incerteza de seu resultado, mas ainda assim, é possível o arranjo de regras e métodos que facilitem a produção de inovações e solução de problemas. Sendo possível afirmar ser a rotina entendida como similar à heurística na tomada de decisão.

\subsubsection{A inovação e o porte das empresas}

Os economistas estão longe de apresentar um pensamento consensual sobre os aspectos econômicos que envolvem inovação e porte das empresas. Segundo Archibugi \& Evangelista \& Simonetti (1993), a inovação é uma das atividades econômicas mais heterogêneas e difíceis de serem medidas ou comparadas. Essa dificuldade, também se aplica às diversas tentativas de se encontrar indicadores eficientes. As medições mais usuais da inovação, tais como: recursos (financeiro e humano) dedicados à P\&D, patentes registradas e outros, têm sido usualmente objeto de alguma controvérsia

Algumas pesquisas com levantamentos estatísticos sobre as inovações, surgidas principalmente a partir dos anos sessenta nos países desenvolvidos, trouxeram novas possibilidades de análise e alguma convergência entre os pesquisadores, com importantes conclusões surgindo na forma de publicações. ${ }^{9}$ No Brasil, esse tipo de pesquisa, sistemática e abrangendo todos os setores industriais, surgiu em 1992, através da Associação Nacional de Pesquisa e Desenvolvimento das Empresas Industriais, ANPEI.

Para determinar qual a participação da pequena empresa na produção de inovações ao longo do tempo, foi realizada uma pesquisa no Reino Unido em 1971, e posteriormente estendida até 1983, pelo Science Policy Research Unit (SPRU). Nessa pesquisa, mediu-se diretamente a quantidade de inovações desenvolvidas pelas empresas no período de 1945 a 1983, classificadas pelo porte da empresa. A tabela 2.1 apresenta os resultados da mesma.

\footnotetext{
${ }^{9}$ Acs \& Audretsch, Freeman \& Soete, Mansfield, Nelson, Pavitt, Scherer e Starr são alguns, entre os vários economistas, que publicaram artigos e/ou livros com base em pesquisas desenvolvidas, principalmente, nos Estados Unidos e países europeus da OECD (Organization for Economic Cooperation and Development).
} 
Tabela 2.1 Inovações nas indústrias do Reino Unido 1945-83

\begin{tabular}{ccccccc}
\hline & \multicolumn{5}{c}{ Tamanho da empresa } \\
Período & $1-199$ & $200-499$ & $500-999$ & $1.000-9.999$ & $>10.000$ & No de inovações \\
\hline $1945-49$ & 16,8 & 7,5 & 5,3 & 28,3 & 42,0 & 226 \\
$1950-54$ & 14,2 & 9,5 & 4,5 & 32,2 & 39,6 & 359 \\
$1955-59$ & 14,4 & 10,1 & 9,1 & 24,9 & 41,4 & 514 \\
$1960-64$ & 13,6 & 9,2 & 6,0 & 27,8 & 43,4 & 684 \\
$1965-69$ & 15,4 & 8,2 & 8,5 & 24,7 & 43,7 & 720 \\
$1970-74$ & 17,5 & 9,0 & 6,3 & 20,7 & 46,5 & 656 \\
$1975-79$ & 19,6 & 9,6 & 7,5 & 16,2 & 46,2 & 823 \\
$1980-83$ & 26,3 & 12,1 & 4,3 & 14,9 & 41,9 & 396 \\
& & & & & & \\
$\begin{array}{c}\text { Número de } \\
\text { inovações }\end{array}$ & 774 & 411 & 299 & 1.004 & 2.020 & 4.378 \\
$\begin{array}{c}\text { Porcentagem } \\
\text { média }\end{array}$ & 17,0 & 9,4 & 6,8 & 22,9 & 43,1 & 100 \\
\hline
\end{tabular}

Fonte: Rothwell and Dodgson (1994), citado por Freeman \& Soete (1997), p. 237.

Observando-se o resultado da pesquisa e admitindo-se que ela é representativa da indústria britânica como um todo, surgem algumas conclusões interessantes, anotadas por Freeman \& Soete (1997) :

- As pequenas empresas são responsáveis por aproximadamente $17 \%$ de todas as inovações realizadas no período de 1945 a 1983. Esse dado é comparável a outros indicadores. Em 1963, essas empresas foram responsáveis por 19\% da produção líquida e por $22 \%$ da geração de empregos.

- A participação das pequenas empresas na inovação era aparentemente regular e estável de 1950 a 1970, mas teve uma subida um tanto abrupta após essa época.

- A participação das grandes empresas (10.000 ou mais funcionários) no número total de inovações aumentou nos anos 60 e 70, mas caiu nos 80.

- No período total, as empresas com mais de 1.000 funcionários foram responsáveis por dois terços de todas as inovações.

De acordo com Freeman \& Soete (1997), apesar das exceções, parece ser verdadeiro que nos setores industriais intensivos em capital, as inovações, tanto de processo como de produtos, têm sido monopolizadas principalmente pelas grandes 
empresas. Os autores também observaram que desde 1970, o aumento de participação das pequenas empresas nas inovações no Reino Unido foi primariamente naquelas indústrias onde a sua contribuição já era forte, especialmente eletrônicos, instrumentos e computadores.

Uma outra pesquisa foi realizada pelo Small Business Administration, SBA, sobre as 8074 inovações introduzidas nos Estados Unidos em 1982. Dessas inovações, 4476 foram identificadas como ocorridas na manufatura. Os dados foram classificados por setor industrial de acordo com a classificação de quatro dígitos da Standard Industrial classification, $(\mathrm{SIC})^{10}$.

Acs \& Audretsch (1991) analisaram os dados da referida pesquisa, utilizando uma medida direta da intensidade de atividade inovadora, o índice de inovação total (TIE) $)^{11}$, que é definido como o número total de inovações por 1.000 empregados em um setor industrial classificado com quatro dígitos da SIC. Para as grandes empresas, o índice de inovação (LIE) é definido como o número de inovações realizado pelas empresas com pelo menos 500 empregados, dividido pelo número de empregados (em milhares) nas grandes empresas. De forma similar, o índice de inovação da pequena empresa (SIE) é definido como o número de inovações introduzido pelas empresas com menos de 500 empregados, dividido pelo número de empregados (em milhares) nas pequenas empresas.

Aplicando os índices, e utilizando uma classificação agrupada dos setores industriais de dois dígitos da SIC, apresentaram os dados da pesquisa do SBA, conforme a tabela 2.2.

\footnotetext{
${ }^{10}$ A Standard Industrial Classification (SIC) do grupo 28, produtos químicos e afins foi anexada no capítulo 7.

${ }^{11} \mathrm{O}$ autor não esclarece o significado da sigla TIE, que pela definição supõe-se ser Total Innovation per thousands employees; por analogia, SIE seria Small firms innovation per thousands employees e LIE Large firms innovation per thousands employees.
} 
Tabela 2.2 Índices de inovação para grandes e pequenas empresas, por setor classificado com dois dígitos SIC, 1982 (desvio padrão entre parênteses)

\begin{tabular}{|c|c|c|c|}
\hline Setor & $\begin{array}{l}\text { Total de } \\
\text { Inovações } \\
\text { (TIE) }\end{array}$ & $\begin{array}{c}\text { Inovações de } \\
\text { grandes empresas } \\
\text { (LIE) }\end{array}$ & $\begin{array}{c}\text { Inovações de } \\
\text { pequenas empresas } \\
\text { (SIE) }\end{array}$ \\
\hline Alimento & $\begin{array}{c}0.2119 \\
(0.1741)\end{array}$ & $\begin{array}{c}0.2555 \\
(0,3120)\end{array}$ & $\begin{array}{l}0.1361^{*} \\
(0,1905)\end{array}$ \\
\hline Têxteis & $\begin{array}{c}0.7040 \\
(0,0612)\end{array}$ & $\begin{array}{c}0.0295 \\
(0,0646)\end{array}$ & $\begin{array}{l}0.1669^{*} \\
(0,1723)\end{array}$ \\
\hline Vestuário & $\begin{array}{c}0,1253 \\
(0,1553)\end{array}$ & $\begin{array}{c}0,0639 \\
(0,1222)\end{array}$ & $\begin{array}{c}0,1439 \\
(0,2076)\end{array}$ \\
\hline Madeira & $\begin{array}{c}0,1400 \\
(0,2179)\end{array}$ & $\begin{array}{c}0,0506 \\
(0,0680)\end{array}$ & $\begin{array}{c}0,1415 \\
(0,2662)\end{array}$ \\
\hline Móveis & $\begin{array}{c}0,3053 \\
(0,2917)\end{array}$ & $\begin{array}{c}0,2412 \\
(0,3759)\end{array}$ & $\begin{array}{c}0,2592 \\
(0,2243)\end{array}$ \\
\hline Papel & $\begin{array}{c}0,1616 \\
(0,1651)\end{array}$ & $\begin{array}{c}0,1931 \\
(0,2821)\end{array}$ & $\begin{array}{c}0,1214 \\
(0,2691)\end{array}$ \\
\hline Gráfico & $\begin{array}{c}0,0426 \\
(0,0350)\end{array}$ & $\begin{array}{c}0,0468 \\
(0,0452)\end{array}$ & $\begin{array}{c}0,0313 \\
(0,0552)\end{array}$ \\
\hline Químico & $\begin{array}{c}0,7592 \\
(0,5945)\end{array}$ & $\begin{array}{c}0,6272 \\
(0,6297)\end{array}$ & $\begin{array}{l}1,3547^{*} \\
(1,5641)\end{array}$ \\
\hline Petróleo & $\begin{array}{c}0,3386 \\
(0,3797)\end{array}$ & $\begin{array}{c}0,0476 \\
(0,0824)\end{array}$ & $\begin{array}{c}0,6173 \\
(0,6591)\end{array}$ \\
\hline Borracha & $\begin{array}{c}0,1204 \\
(0,0787)\end{array}$ & $\begin{array}{c}2,1814 \\
(4,1868)\end{array}$ & $\begin{array}{c}0,1129 \\
(0,1779)\end{array}$ \\
\hline Couro & $\begin{array}{c}0,1356 \\
(0,1487)\end{array}$ & $\begin{array}{c}0,0053 \\
(0,0106)\end{array}$ & $\begin{array}{l}0,1793^{*} \\
(0,1695)\end{array}$ \\
\hline Pedra, argila, vidro & $\begin{array}{c}0,2130 \\
(0,1640)\end{array}$ & $\begin{array}{c}0,1625 \\
(0,2116)\end{array}$ & $\begin{array}{c}0,2696 \\
(0,1979)\end{array}$ \\
\hline Metais primários & $\begin{array}{c}0,1586 \\
(0,2905)\end{array}$ & $\begin{array}{c}0,1624 \\
(0,3394)\end{array}$ & $\begin{array}{c}0,3336 \\
(0,8319)\end{array}$ \\
\hline Produtos metálicos & $\begin{array}{c}0,3224 \\
(0,3109)\end{array}$ & $\begin{array}{c}0,2878 \\
(0,3357)\end{array}$ & $\begin{array}{c}0,3619 \\
(0,3862)\end{array}$ \\
\hline Maquinário (não elétrico) & $\begin{array}{c}0,6039 \\
(0,6728)\end{array}$ & $\begin{array}{c}0,4860 \\
(0,5673)\end{array}$ & $\begin{array}{l}1,1491^{*} \\
(1,7965)\end{array}$ \\
\hline Equipamento elétrico & $\begin{array}{c}0,3713 \\
(0,3510)\end{array}$ & $\begin{array}{c}0,2719 \\
(0,3263)\end{array}$ & $\begin{array}{l}0,7948^{*} \\
(0,7912)\end{array}$ \\
\hline Equipamento de transporte & $\begin{array}{c}0,1250 \\
(0,1289)\end{array}$ & $\begin{array}{c}0,1182 \\
(0,1868)\end{array}$ & $\begin{array}{c}0,1911 \\
(0,3349)\end{array}$ \\
\hline
\end{tabular}

Fonte: Acs \& Audretsch (1991) p. 22

Nota: * Indica que a diferença entre os índices de inovação da grande e pequena empresa é estatisticamente significante, com $90 \%$ de nível de confiança.

$O$ índice total de inovações, TIE, é calculado considerando o $n^{0}$ total de inovações dividido pelo $n^{0}$ de empregados em milhares. O LIE e o SIE são calculados de forma similar ao TIE, porém com os dados específicos da grande e pequena empresa respectivamente. 
Em relação à tabela 2.2 apresentada, os autores comentam:

- Os índices totais de inovação (TIE) mais altos, que portanto indicam os setores industriais mais inovadores, são: instrumentos (1,3586); químico $(0,7592)$ e maquinário não elétrico $(0,6039)$.

- Os índices totais (TIE) mais baixos, que indicam os setores menos inovadores são: gráfico $(0,0426)$; têxteis $(0,0740)$ e borracha $(0,1204)$.

- Em geral, não parece existir uma relação estreita entre o índice das grandes (LIE) e pequenas empresas (SIE).

- Alguns contrastes entre LIE e SIE são observados. Enquanto o maior LIE é na indústria de borracha, SIE é quase o menor de todos nesta indústria. De forma similar, LIE é relativamente pequeno na indústria de petróleo e SIE é relativamente alto.

- Está claro que a diferença dos índices de inovações entre a grande e pequena empresa varia de forma considerável conforme o setor industrial. SIE é maior que LIE em quatorze setores e LIE é maior que SIE em quatro.

Acs \& Audretsch (1991) observam que pouco tem sido estabelecido na literatura econômica para identificar as condições e ambientes de mercado que são contributivos para a atividade inovadora. As pesquisas empíricas têm tido a tendência de enfocar as grandes empresas, negligenciando as pequenas.

Segundo os autores, surgiram duas posições polêmicas quanto às vantagens relativas da grande e pequena empresa nas atividades inovadoras. Por um lado, a doutrina clássica e neoclássica sugerem que as pequenas empresas, incentivadas pela competição, são as que mais propiciam o progresso tecnológico. Por outro lado, os economistas adeptos da visão de Schumpeter argumentam que as grandes empresas são as únicas dotadas com capacidade para explorar as oportunidades inovadoras e que a predominância do mercado é um pré-requisito para se empreender os riscos e incertezas associados com a inovação.

Os autores identificaram na literatura econômica cinco fatores que evidenciam vantagens comparativas da grande empresa nas atividades inovadoras:

1) A atividade inovadora requer um alto custo fixo;

2) Somente as empresas que podem conseguir, ao menos temporariamente, controle do mercado, irão escolher a inovação como um meio para maximização do lucro; 
3) P\&D é um investimento de risco e geralmente alto; as pequenas empresas se tornam vulneráveis à medida que investem uma grande parte de seus recursos em um simples projeto. Ao contrário, as grandes empresas podem investir numa carteira de projetos, diluindo, assim, os riscos e se tornando menos vulneráveis. As grandes empresas também podem, com maior probabilidade, encontrar aplicações econômicas para os subprodutos provenientes da atividade inovadora;

4) A economia de escala na produção, distribuição e promoção facilita a penetração de novos produtos, permitindo que as grandes empresas desfrutem de um potencial de lucro maior com a inovação;

5) Uma inovação pode permitir reduções de custos de uma certa porcentagem, o que resulta em maiores margens de lucro para a grande empresa do que para a pequena.

Segundo Acs \& Audretsch (1991), os fatores que trazem vantagem para a pequena empresa na atividade inovadora são provenientes, em geral, das características da estrutura de gerenciamento, tais como:

1) Para conseguir desenvolver uma inovação na grande empresa, as idéias inovadoras precisam sobreviver às diversas camadas de resistência burocrática existentes. Em contrapartida, a decisão para inovar nas pequenas empresas envolve poucas pessoas;

2) A atividade inovadora pode florescer melhor em ambientes livres das restrições burocráticas. Observa-se que alguns pesquisadores sentem-se paralisados pelas restrições administrativas das grandes empresas e atraídos pela liberdade das pequenas;

3) Enquanto as grandes empresas deslocam seus pesquisadores, promovendo-os às atividades administrativas, o mesmo não ocorre na pequena empresa que coloca a atividade inovadora no centro de sua estratégia competitiva.

Scherer (1988), citado por Acs \& Audretsch (1991), resumiu as vantagens que a pequena empresa tem em relação à grande para desenvolver inovações, com os seguintes pontos: 
1) A pequena empresa é menos burocrática;

2) Muitos avanços tecnológicos são frutos da acumulação de um enorme número de pequenas invenções, envolvendo componentes individuais, materiais e técnicas de produção. As possibilidades de vendas desses avanços são, em geral, muito modestas para interessar às grandes empresas;

3) É mais fácil manter um ambiente de agitação e estímulo nas pequenas organizações, onde as ligações entre desafios, equipes e recompensas potenciais são mais fortes.

Analisando as vantagens e desvantagens da pequena empresa em relação à grande, na atividade de inovação, Freeman \& Soete (1997) assinalaram os seguintes pontos:

- Parece razoável supor que a pequena empresa tem alguma vantagem comparativa nos estágios iniciais do trabalho inventivo e menos custoso, enquanto a grande empresa leva vantagem nos estágios finais, principalmente, nas inovações radicais.

- Existem alguns tipos de inovação que estão além da capacidade da pequena empresa, em termos de recursos. O número absoluto de componentes de um artefato é um dos fatores que pode inibir a presença da pequena empresa.

- A grande empresa leva vantagem quando existem várias rotas alternativas possíveis no desenvolvimento de um produto, com incertezas em todas elas, mas também com benefícios em se trabalhar com diversas delas simultaneamente. De forma similar, a grande empresa terá vantagem quando for necessário um grande número de diferentes especialistas para solucionar problemas ou quando uma instrumentação cara é essencial.

- Provavelmente, a maior vantagem da pequena empresa reside em flexibilidade, concentração do esforço gerencial e comunicação interna. Uma ligação eficiente entre marketing/produção com tomada de decisão em P\&D pode ser muito mais fácil de se conseguir no ambiente da pequena empresa.

- Em um trabalho sobre o setor de instrumentos, realizado por Shimshoni (1966), citado por Freeman \& Soete (1997), foi detectado que a vantagem das pequenas empresas em inovação se devia aos seguintes fatores: motivação, baixo custo, duração do desenvolvimento (lead time) e flexibilidade.

Acs \& Audretsch (1991) analisaram algumas questões relativas à estrutura de mercado e fazem os seguintes comentários: 
- Alguns estudos, incluindo Pavitt \& Wald (1971), sugerem que a oportunidade de inovação para a pequena empresa tende a ser maior quando a indústria está nos estágios iniciais do ciclo de vida do produto.

- Utilizando os dados da pesquisa do SBA de 1982, foi constatado que a atividade inovadora de um setor industrial tende a decrescer à medida que o nível de concentração cresce. Esta conclusão vai contra a hipótese que surgiu na literatura de que a atividade inovadora é impulsionada em mercados caracterizados pela competição imperfeita. Os autores também constataram que existem dois regimes tecnológicos distintos e que são produtos do ambiente da estrutura de mercado. O primeiro deles, formado pelos setores intensivos em capital, concentrados, altamente sindicalizados e produzindo produtos diferenciados, tende a ser caracterizado como regime de rotina. O outro, em contraste, composto de setores altamente inovadores, onde o uso de mão-de-obra especializada é relativamente importante e onde as grandes empresas têm uma grande participação no mercado, é caracterizado como regime empreendedor.

- Existem três correntes da literatura para explicar a variação da presença das pequenas empresas nos diversos setores industriais, a saber:

a) A primeira corrente está voltada para a distribuição intra-setor do tamanho da empresa e atribui esta distribuição à existência de um estoque exógeno de habilidades ou competências empreendedoras dos agentes administrativos.

b) A segunda corrente, preocupando-se com a variação inter-setores, propõe que a distribuição do tamanho de empresa é determinada pela natureza da função custo médio de longo prazo. Nessa concepção, o custo médio é constante após um certo nível de produção; esse nível de produção define a escala mínima de eficiência (MES - Minimum efficient scale). Quanto maior a produção requerida para atingir a escala mínima de eficiência (MES), menos hospitaleiro será o setor industrial com as pequenas empresas. Outro fator que influencia a viabilidade das pequenas empresas é o capital absoluto requerido, ou a quantidade de capital necessário para que uma empresa possa exaurir a economia de escala. Um alto capital absoluto requerido servirá como impedimento para as pequenas empresas ${ }^{12}$.

12 Os autores argumentam que as grandes empresas levam vantagem quando o capital absoluto requerido é alto, devido às seguintes observações: a)podem se auto-financiar; b) conseguem melhores taxas de juros para financiamentos; c) em geral, estão menos sujeitas às restrições de liquidez. 
A vantagem relativa das pequenas empresas é nos setores onde existe necessidade de pequenos aportes de capital ou aqueles setores onde o MES e o capital absoluto requerido são pequenos. O quanto a propaganda e publicidade têm de importância no setor pode também afetar a viabilidade da pequena empresa.

c) A terceira corrente da literatura sugere que as empresas menores podem compensar as desvantagens de custo específicas do tamanho, através de uma estratégia de flexibilidade na produção e no desenvolvimento de P\&D.

- Pequenas empresas tendem a ter vantagens na atividade inovadora nos setores industriais constituídos predominantemente de grandes empresas. Isso é consistente com a noção de que as pequenas empresas têm um papel importante na introdução de novos produtos, mesmo em setores dominados por grandes organizações.

- O resultado empírico sugere que tanto as grandes como as pequenas empresas exercem um papel importante no processo inovador, embora suas funções sejam diferentes e requeiram ambientes distintos para a sua promoção.

- A difusão e implementação do controle numérico para as máquinas ferramentas reduziu bastante o tamanho médio das empresas no setor e aumentou a participação das pequenas empresas no mercado.

- Alguns estudos recentes têm demonstrado que as pequenas empresas tendem a ter taxas mais alta de crescimento. No entanto, quando se incorpora à medida o impacto das saídas, verifica-se que, na maioria dos setores industriais, o crescimento é igual entre pequenas e grandes empresas.

No Brasil, aparentemente, não se realiza pesquisa que meça diretamente a produção de inovações. Os indicadores empresariais de inovação tecnológica da ANPEI utilizam uma medição indireta das inovações através de índices como faturamento gerado por produtos lançados no mercado, número de patentes, despesas com P\&D e outros.

A ANPEI adota o seguinte critério para o porte das empresas:

Micro - empresas de 1 a 19 empregados 


$$
\begin{aligned}
& \text { Pequeno - empresas de } 20 \text { a } 99 \text { empregados } \\
& \text { Médio - empresas de } 100 \text { a } 499 \text { empregados } \\
& \text { Grande - empresas de } 500 \text { a } 9.999 \text { empregados } \\
& \text { Mega - empresas com mais de } 10.000 \text { empregados }
\end{aligned}
$$

Os resultados da base de dados ANPEI de dezembro de 1997, referentes ao ano de 1996, contaram com a participação de 362 empresas. Analisando-se a figura 2.2, extraída desta publicação da ANPEI, é possível se ter uma idéia da participação das pequenas empresas nas atividades inovadoras.

Figura 2.2 Faturamento gerado por produtos lançados no mercado nos últimos 5 anos (valores médios por empresa)

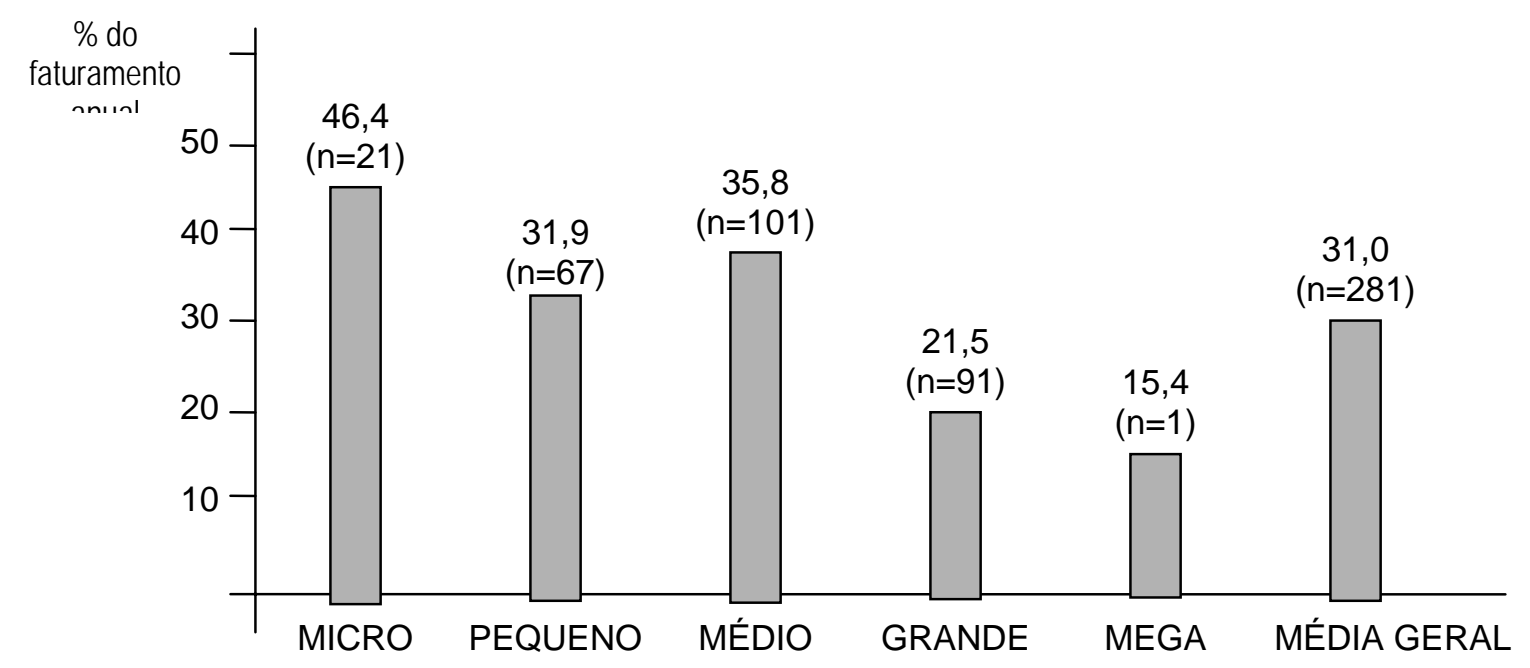

Fonte: Resultado da base de dados ANPEI, Dezembro 1997, p. 47

Nota: Dados referentes ao ano de 1996 


\subsection{O setor industrial químico}

A importância das indústrias químicas e petroquímicas para a economia mundial começou efetivamente após a segunda guerra mundial. Com o conhecimento científico e tecnológico acumulado nas décadas anteriores e uma demanda crescente por novos produtos, intensificou-se o processo de substituição de materiais extraídos da natureza por substitutos sintéticos. Mas o grande salto transformador na indústria química ocorreu com a passagem de processos produtivos em bateladas para processos de fluxo contínuo. Essa mudança permitiu grandes ganhos de eficiência e melhor controle do processo, tornando os produtos mais acessíveis. Tal passagem para processos produtivos de fluxo contínuo foi facilitada, segundo Freeman \& Soete (1997), por seis desenvolvimentos ocorridos durante os séculos XIX e XX:

1) O enorme crescimento do mercado para produtos químicos básicos, tais como soda, amônia, cloro, ácido sulfúrico, etileno e propileno. Esses produtos, chamados de "building blocks", são usados como materiais intermediários para uma grande variedade de outras indústrias químicas e outros setores industriais.

2) A mudança nos materiais básicos da química orgânica, do carvão para o petróleo e gás natural. Essa mudança estimulou os processos contínuos agregados às refinarias.

3) O aumento da disponibilidade da eletricidade como fonte de energia e o desenvolvimento de processos eletrotérmicos e eletrolíticos.

4) O desenvolvimento de novos materiais para construção das plantas. Essa melhoria foi essencial para permitir o uso de equipamentos em condições mais severas de pressão e temperatura, exigidas pelos processos contínuos.

5) O desenvolvimento de novos instrumentos para monitorar e controlar os fluxos no processo contínuo, bem como as análises de laboratório.

6) A aplicação do conhecimento científico básico para o processo produtivo e o desenvolvimento da engenharia química.

Segundo Freeman \& Soete (1997), durante o século XIX, as descobertas na área química que se tornaram inovações importantes, foram na sua maior parte empreendimentos individuais, conduzidos por químicos. Esses cientistas, tais como, Alfred Nobel, Ernest Solvay e outros, investiram vários anos em pesquisa que era patrocinada pelo próprio pesquisador. As empresas que surgiram a partir das inovações desses pesquisadores, tornaram-se as grandes indústrias químicas do século $X X$.

No início do século $X X$, surge o craqueamento do petróleo e com ele a grande expansão das refinarias nos Estados Unidos. O desenvolvimento de novos processos, tanto 
nas refinarias de petróleo como nas indústrias químicas se torna um negócio de altos investimentos, não mais suportável pelos pesquisadores individuais. Começa uma nova era de P\&D comandado pelas grandes corporações.

Além do alto investimento necessário para se desenvolver um novo processo ou produto na indústria química, Freeman \& Soete (1997) observam que o fator economia de escala se faz presente nas plantas de grande capacidade. A razão deste fato é que uma planta química é composta em grande parte de equipamentos com formato cilíndrico (colunas, tanques, tubulação, trocadores de calor e outros). Como a capacidade é função do volume e o custo do capital é, em grande parte, função da área dos equipamentos, com pequenos acréscimos de capital, é possível se obter aumentos consideráveis da capacidade $^{13}$. Mas segundo os autores, as grandes plantas tiveram, além do ganho em custo de capital, vantagens provenientes da economia com supervisão, energia, manutenção, mão-de-obra para operação e outros.

Nos anos 80 e 90, com as mudanças na ciência e tecnologia, estão surgindo novos materiais, principalmente em desenvolvimento nas áreas de biologia e bioquímica. Junto com esses novos produtos surgem as pequenas empresas de base tecnológica, em geral, originárias das universidades.

De acordo com a classificação nacional das atividades econômicas do IBGE, são consideradas como indústria química as atividades do capítulo 24, Fabricação de produtos químicos, que inclui os seguintes segmentos:

24.1 Fabricação de produtos químicos inorgânicos

24.2 Fabricação de produtos químicos orgânicos

24.3 Fabricação de resinas e elastômeros

24.4 Fabricação de fibras, fios, cabos e filamentos contínuos artificiais e sintéticos

24.5 Fabricação de produtos farmacêuticos

24.6 Fabricação de defensivos agrícolas

24.7 Fabricação de sabões, detergentes, produtos de limpeza e artigos de perfumaria

24.8 Fabricação de tintas, vernizes, esmaltes, lacas e produtos afins

24.9 Fabricação de produtos e preparados químicos diversos

Segundo a Associação Brasileira das Indústrias Químicas, ABIQUIM, o faturamento global líquido da indústria química brasileira em 1997 foi de US\$41,8 bilhões. A tabela 2.3 ilustra a distribuição deste faturamento pelos diversos segmentos.

\footnotetext{
${ }^{13}$ Enquanto o volume do cilindro é $\mathrm{pr}^{2} \mathrm{~h}$, a área da superfície do cilindro é 2prh.
} 
Tabela 2.3 Faturamento da indústria química no Brasil - 1997

\begin{tabular}{|l|c|}
\hline \multicolumn{1}{|c|}{ SETOR INDUSTRIAL QUÍMICO } & \% DO FATURAMENTO TOTAL \\
\hline \hline Produtos básicos e intermediários & 30,9 \\
Farmacêuticos & 25,6 \\
Higiene pessoal & 10,0 \\
Adubos e fertilizantes & 7,7 \\
Sabões e detergentes & 5,7 \\
Tintas, esmaltes e vernizes & 5,3 \\
Defensivos agrícolas & 5,0 \\
Fibras e sintéticos & 3,1 \\
Gases industriais & 2,9 \\
Fotoquímicos & 2,4 \\
Outros & 1,4 \\
\hline
\end{tabular}

Fonte: ABIQUIM, sistema dinâmico de informações

Segundo Pratten (1991), uma característica particular da indústria química é a sua grande variedade de produtos, dificultando qualquer tentativa de classificação. Uma forma prática e freqüente, tem sido o agrupamento desses produtos em três grandes categorias: produtos básicos, intermediários químicos e produtos finais.

De acordo com o diagnóstico setorial da indústria química-petroquímica brasileira, preparado pelo Conselho estadual de Política Industrial, Comercial e Agroindustrial, COINCO (1985), existem três estágios de processamento petroquímico: a) o processo primário que é responsável pela maior parte da produção petroquímica, onde a maior parte das commodities são produzidas; b) estágio intermediário, quando começa a ocorrer a modificação dos produtos primários, gerando um grande número de produtos químicos. Neste estágio, os produtos são comercializados em volumes menores, mas ainda considerados como commodities ou "pseudocommodities"; c) no estágio final encontram-se os "pseudo-commodities" que são produzidos em grandes volumes e processo contínuo, bem como as formulações de pequeno volume produzidas em bateladas.

A indústria química e petroquímica pode ser segmentada em grupos de produtos e empresas que possuem características semelhantes, conforme o quadro 2.2. 


\section{Quadro 2.2 Características dos quatro segmentos de produtos petroquímicos}

\begin{tabular}{|c|c|c|c|c|}
\hline Características & Commodities & "Pseudo-commodities" & Química fina & $\begin{array}{l}\text { Especialidades } \\
\text { químicas }\end{array}$ \\
\hline Volume de produção & Grande & Grande & Pequeno & Pequeno \\
\hline Processo & $\begin{array}{c}\text { Síntese } \\
\text { (geralmente) }\end{array}$ & $\begin{array}{l}\text { Síntese, algumas } \\
\text { vezes formulação }\end{array}$ & Síntese & $\begin{array}{l}\text { Formulação, algumas } \\
\text { vezes síntese }\end{array}$ \\
\hline Matérias-primas & $\begin{array}{l}\text { Freqüentemente } \\
\text { cativas }\end{array}$ & $\begin{array}{l}\text { Freqüentemente } \\
\text { cativas }\end{array}$ & $\begin{array}{l}\text { Freqüentemente } \\
\text { compradas }\end{array}$ & $\begin{array}{l}\text { Freqüentemente } \\
\text { compradas }\end{array}$ \\
\hline Especificações & Composição & Desempenho & Composição & $\begin{array}{c}\text { solução do problema } \\
\text { do usuário }\end{array}$ \\
\hline Tamanho do mercado & Grande & Grande & Pequeno & Pequeno \\
\hline $\begin{array}{l}\text { Concentração do } \\
\text { mercado }\end{array}$ & Alta & Alta & Alta & $\begin{array}{l}\text { Freqüentemente } \\
\text { pequeno }\end{array}$ \\
\hline
\end{tabular}

Fonte: Rosenberg \& Kline (1981), citado por COINCO (1985).

Neste trabalho, pretende-se pesquisar a pequena indústria química, que se encontra, normalmente, no segmento de química fina e especialidades químicas e eventualmente em pseudo-commodities.

O segmento da química fina e especialidades, além das características citadas no quadro 2.3, segundo o COINCO (1985), apresentam as seguintes evidências:

- As plantas produzem uma gama diferenciada de produtos em pequena quantidade;

- As plantas e os equipamentos são menos complexos e geralmente podem atender a múltiplas finalidades;

- O planejamento da produção é realizado para pequenos períodos e sujeito a mudanças freqüentes; 
- As matérias-primas são compradas de acordo com as necessidades;

- O risco de fracasso é pequeno, porém existem riscos muito altos derivados da obsolescência do produto;

- Os custos de entrada neste mercado são altos em termos de investimento em P\&D, aprovação do produto para produção e vendas, desenvolvimento dos mercados;

- Em especialidades químicas, os serviços técnicos são importantes, incluindo um bom conhecimento da utilização do produto e o retorno das informações técnicas dos usuários;

- Em química fina, a pureza de uma batelada em relação a outra é crítica. 


\subsection{Características da pequena empresa}

Para a teoria econômica clássica, a pequena empresa tem um papel secundário na economia, que é de dependência das grandes empresas. Essa idéia, que em grande parte surgiu com o conceito de escala mínima de produção, prevaleceu até recentemente. Com a nova visão trazida pela teoria evolucionária da mudança econômica, onde a inovação é tratada como uma força fundamental, surge uma nova concepção do papel da pequena empresa (Acs \& Tarpley \& Phillips, 1998).

Analisando as pequenas empresas, Pratten (1991), observou que os principais aspectos que justificam a sua existência, são:

\section{a) A dimensão da escala mínima de produção}

Cada empresa, em geral, produz diversos produtos que envolvem várias etapas de processamento. Em cada uma dessas etapas existe uma escala mínima de produção, que pode definir tamanhos diferentes de empresas. É bastante provável, que em alguns pontos desta cadeia de produção, a pequena empresa seja mais eficiente que uma grande.

\section{b) A flexibilidade}

Admitindo-se que a relação entre os custos unitários e a quantidade produzida é uma curva do tipo $U$, quanto mais plana for a curva (os custos marginais se alteram pouco com a variação da quantidade), maior será a flexibilidade da empresa, em termos de custo de produção. A figura 2.3 ilustra este conceito.

\section{Figura 2.3 Custos unitários e flexibilidade}

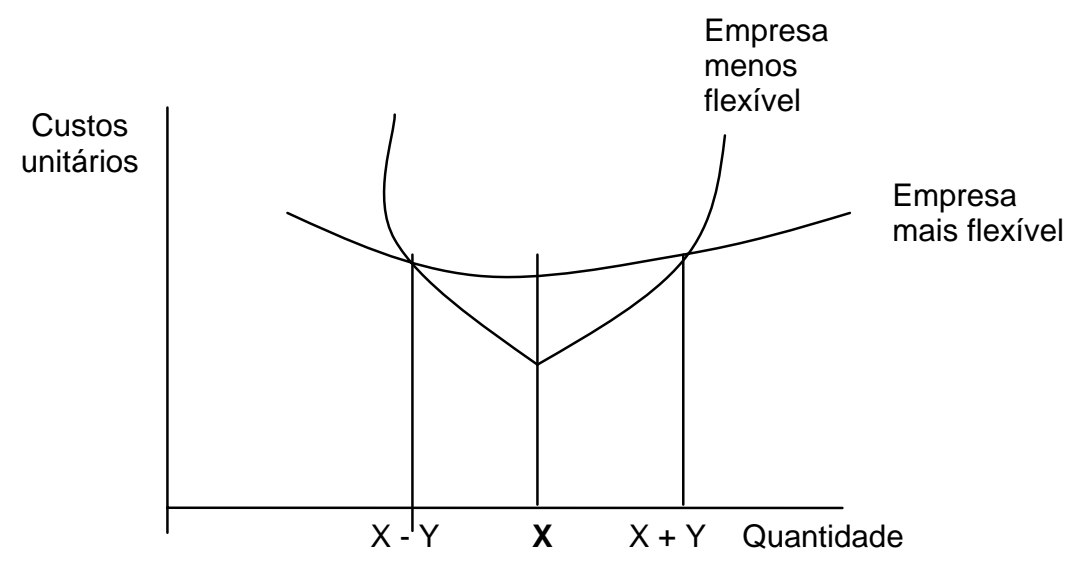

Fonte: Pratten, 1991, p. 29

A empresa menos flexível consegue custos unitários menores dentro de uma faixa limitada de quantidade produzida, entre $(X-Y)$ a $(X+Y)$, enquanto a empresa 
mais flexível leva vantagem fora dessa faixa. Associando-se esse fato à incerteza da demanda, é possível admitir a existência da pequena empresa.

\section{c) Custo de transação}

A pequena empresa pode se especializar em um ou mais estágios da cadeia de produção, onde os custos de transação, além de outros fatores, the são vantajosos. Outro aspecto a favor da pequena empresa, é que a relação entre a direção e os outros agentes (principalmente os empregados e clientes) é estabelecida mais facilmente neste tipo de empresa.

\section{d) Novas empresas}

As novas empresas, em geral, nascem pequenas.

\subsubsection{A empresa familiar}

Grande parte das pequenas empresas são familiares. Por esse motivo, parece conveniente a inclusão de algumas observações sobre tal tipo de empresa.

Segundo Longenecker \& Moore \& Petty (1994), a empresa familiar é aquela cuja propriedade, ou algum outro tipo de envolvimento, está relacionado com pelo menos dois membros de uma família. A natureza e extensão do envolvimento pode variar para cada caso. Outra forma de caracterizar uma empresa familiar é como sendo aquela cujo negócio passa de uma geração para outra.

Embora a maior parte das empresa familiares seja de pequeno porte, também existem grandes empresas familiares.

$\mathrm{Na}$ empresa familiar existe uma sobreposição entre a família e o negócio. Ainda que sejam instituições bem diferentes quanto aos seus objetivos e interesses, alguns pontos podem se sobrepor, provocando eventuais conflitos. A família busca 0 desenvolvimento e a criação de seus membros, enquanto a empresa tem como principal objetivo a lucratividade e a sobrevivência.

A principal questão na empresa familiar, segundo Pickle \& Abrahamson (1990), é a sua administração. Quando os membros da família participam da administração da empresa, existe uma grande chance das decisões empresariais sofrerem a influência das emoções trazidas pelo relacionamento familiar. Nesse caso, o potencial de conflito e prejuízo para administração da empresa são grandes. Em contrapartida, pode existir algumas vantagens para a administração familiar. Davis, P. (1983), citado por Longenecker \& Moore \& Petty (1994), identificou três aspectos que podem tornar as decisões de uma administração familiar superiores às da administração profissional:

- Local de trabalho mais humano;

- Enfocada no longo prazo; 
- Ênfase em qualidade.

A empresa familiar, conforme observado por Longenecker \& Moore \& Petty (1994), tem a tendência de apresentar uma cultura extraída dos valores enfatizados pelo seu fundador. Isto ocorre quando os valores da família fundadora são adotados pelo grupo, o que nem sempre acontece.

Para Dyer (1986), citado por Longenecker \& Moore \& Petty (1994), a configuração cultural da empresa familiar é formada por três tipos de padrões: 1) familiar; 2) empresarial; 3) de controle. Nos estágios iniciais de existência da empresa, o mais comum é a combinação de um padrão de negócio paternalista com um padrão familiar do tipo patriarcal e um conselho de controle fictício. Com o tempo, a tendência é que essa configuração passe para uma combinação de padrão empresarial profissional, um padrão familiar conflituoso e um conselho de controle do tipo supervisão.

\subsubsection{O empreendedor}

Segundo Pickle \& Abrahamson (1990), as principais características de personalidade e habilidades que o empreendedor deve possuir para obter sucesso no seu empreendimento, e que por conseguinte estabelecem o padrão de desempenho da pequena empresa, são:

\section{a) Motivação pessoal para o empreendimento}

Esta motivação pode ser considerada pelos traços de personalidade do empreendedor, tais como, responsabilidade, vigor, iniciativa, persistência e ambição

\section{b) Habilidade mental}

O empreendedor precisa possuir um nível de inteligência alto, conjugando o uso da criatividade para se adaptar às necessidades do negócio em situações diversas com uma boa capacidade analítica para solucionar os problemas que surgem.

\section{c) Habilidade em relações humanas}

Esta habilidade é demonstrada através de alguns fatores de personalidade, tais como, estabilidade emocional, habilidade nas relações interpessoais, sociabilidade, discrição e empatia. 


\section{d) Habilidade de comunicação}

É importante que o empreendedor possua uma boa habilidade de comunicação escrita e verbal, para que haja uma interação de idéias entre ele e os diversos níveis internos, além do relacionamento com agentes externos.

\section{e) Conhecimento técnico}

Conhecimento técnico nas áreas tradicionais de qualquer negócio (operação, marketing, finanças, recursos humanos, desenvolvimento de produtos e outras), no sentido de saber administrar a empresa.

\section{f) Habilidade na tomada de decisão}

As decisões estratégicas da pequena empresa, normalmente, passam pelo seu principal administrador e a qualidade delas define o caminho para o sucesso ou não do empreendimento.

\section{g) Habilidade conceitual}

Esta habilidade refere-se à capacidade do empreendedor em compreender como as partes da sua empresa se interagem e como esta empresa interage com o meio ambiente, o que permite ao empreendedor reconhecer as oportunidades e ameaças para o negócio.

Longenecker \& Moore \& Petty (1994), analisando as características do empreendedor, identificaram os seguintes aspectos:

\section{1) Necessidade de realização}

As pessoas com baixa necessidade de realização são aquelas que estão satisfeitas com seu status atual, enquanto os indivíduos com alta necessidade de realização gostam de competir com um padrão de excelência e preferem ser pessoalmente responsáveis pelas suas próprias tarefas. Segundo os autores, McClelland descobriu uma correlação positiva entre a necessidade de realização e a atividade empreendedora.

\section{2) Disposição para assumir riscos}

Os riscos para um empreendedor são de vários tipos. Financeiro, se ele empregou seu próprio capital no negócio. Se deixou um emprego para começar um novo negócio, existe o risco da sua carreira. O stress e o tempo dispensado ao negócio pode também colocar sua família em risco. Finalmente, o risco psíquico de falha do negócio. Segundo McClelland, citado pelos autores, indivíduos com alta necessidade de realização também apresentam uma propensão ao risco moderada. Isso significa que eles preferem situações de risco, nas quais possam exercer algum controle sobre o resultado, em contraste com a situação de um jogo, na qual o resultado depende de pura sorte. 


\section{3) Auto confiança}

Estudos mostram que os empreendedores de sucesso tendem a ser pessoas auto-confiantes que vêem os problemas como uma nova aventura, mas que acreditam na sua própria habilidade em superá-los. De acordo com J. B. Rotter, citado pelos autores, as pessoas que acreditam que o seu sucesso depende do próprio esforço, têm um lócus interno de controle. Por outro lado, aqueles que sentem que a sua vida é controlada em grande parte pela sorte ou destino, têm um lócus externo de controle.

\section{4) Uma necessidade de buscar amparo}

Embora a maior parte das pessoas se tornem empreendedores para obter a recompensa do negócio, existem aqueles que se tornam empreendedores para fugir de algum fator ambiental. Este fato, segundo os autores, foi identificado pelo professor Russell M. Knight.

\section{5) O "refugiado estrangeiro"}

Muitos estrangeiros para escapar das discriminações buscam o seu próprio negócio como forma de conseguirem uma remuneração.

6) O "refugiado da corporação"

Indivíduos que não se sentem bem com o ambiente burocrático das grandes e médias empresas e por esta razão partem para o seu próprio negócio, são chamados, pelo professor Knight, de "refugiados das corporações".

\section{7) Outros "refugiados"}

O professor Knight identifica outros tipos de "refugiados": o parental, que deixa o negócio da família e busca o seu próprio negócio como forma de provar sua capacitação; a feminista, que experimentou discriminações e resolve começar seu negócio para evitar o chauvinismo masculino; a dona de casa, que inicia seu negócio quando a família já está crescida e ela pode se ver livre das ocupações familiares; da sociedade, quando sente alguma alienação da cultura prevalecente; o educacional, aquele que se cansa da vida acadêmica. 


\subsubsection{A importância da pequena empresa}

As pesquisas americanas têm demonstrado um inequívoco crescimento relativo da pequena indústria ${ }^{14}$ a partir da década de setenta. Conforme exposto por Acs \& Audretsch (1991), uma pesquisa do Statistical Abstract of United States realizada em 1987 revelou que as empresas com menos que cem funcionários e mais que dezenove, no período entre 1975 e 1984, cresceram anualmente em média 3,64\%, enquanto as empresas com mais de mil funcionários, para o mesmo período, cresceram em média 1,25\%. Esse resultado poderia, à primeira vista, ser interpretado como fruto da transição que está ocorrendo em praticamente todas as economias do mundo, do aumento do setor de serviços e redução do setor industrial. Este é um fato que realmente ocorreu nos Estados Unidos neste período, porém não serve para explicar o crescimento da pequena empresa, pois conforme argumentam os autores, a transformação da atividade econômica das grandes empresas em pequenas tem sido ainda maior na manufatura do que no setor de serviços.

Reforçando a importância da pequena empresa para a economia americana, Pickle \& Abrahamson (1990) citam os seguintes fatos:

\section{Com relação ao emprego:}

- Gera aproximadamente $67 \%$ das oportunidades iniciais de trabalho.

- É responsável pela maioria dos treinamentos no local de trabalho, em habilidades básicas, oferecidos aos jovens.

- Provê empregos para aproximadamente $56 \%$ da força de trabalho americana, excluindo o emprego no campo.

- Entre as que oferecem emprego, aproximadamente $60 \%$ têm menos que 5 empregados, e $90 \%$ têm menos que vinte.

\section{Com relação à presença na economia:}

- É responsável por aproximadamente 38\% do produto bruto nacional, GNP, gross national product.

- Responde por $42 \%$ de todas as vendas nos Estados Unidos.

- Supre, direta ou indiretamente, o sustento de mais de cem milhões de americanos.

Acs \& Audretsch (1991) consideram que as evidências estatísticas de que as pequenas empresas estão com uma participação mais importante em todos os setores da

\footnotetext{
${ }^{14}$ Para os pesquisadores americanos, em geral, a pequena empresa é aquela que possui menos que quinhentos funcionários. Quando não for este o critério será feita uma observação a respeito.
} 
economia, são convincentes e citam seis fatores que têm sido considerados como hipóteses para explicar a causa dessa recente emergência:

1) O efeito de "descentralização" de certas tecnologias, tais como as máquinas ferramentas com controle numérico, que tem contribuído para uma redução na escala mínima de eficiência;

2) A globalização tem tornado os mercados mais voláteis, como resultado do aumento de competidores externos e flutuações do câmbio. Nesta situação, a flexibilidade organizacional e produtiva, que tende a ser maior na pequena empresa, está se tornando um valioso recurso;

3) A mudança na composição da força de trabalho pode ser um catalisador para as pequenas empresas. O aumento da participação da mulher e a entrada da geração "baby-boom"15 no mercado de trabalho, pode ter aumentado a oferta do tipo de trabalhador mais adequado à pequena empresa;

4) A proliferação da mudança de preferência dos consumidores do produto de massa, padronizado, para produtos personalizados. Por conseguinte, as pequenas bateladas de produto customizado estão substituindo as grandes produções de produto padronizado; com a tendência de reduzir a desvantagem em custo da pequena escala de produção;

5) O movimento recente de desregulamentação da economia pode também ter contribuído para a viabilidade da pequena empresa;

6) Os Estados Unidos estão atravessando, no momento, um período de "destruição criativa", conforme o modelo evolucionário de Schumpeter, onde os empreendedores desenvolvem novos produtos e processos que no final das contas deslocam as empresas e instituições estabelecidas.

No Brasil, de acordo com a pesquisa "Estrutura produtiva empresarial brasileira (1994)", apresentada pelo Instituto Brasileiro de Geografia e Estatística, IBGE, as 1.651.422 empresas cadastradas empregavam 12.266.765 pessoas. Através da análise das tabelas 2.4 e 2.5 pode-se verificar a importância da pequena indústria para a economia brasileira.

\footnotetext{
15 "baby-boom" é uma expressão utilizada para designar a enorme quantidade de nascimentos ocorrida nos Estados Unidos após a II Grande Guerra e baby boomers ao conjunto de pessoas que nasceram nesta época (Engel, Blackwell \& Miniard, 1995, p. 62).
} 
Tabela 2.4 Distribuição das empresas cadastradas

\begin{tabular}{|c|c|c|c|}
\hline Setor & $\begin{array}{c}N^{0} \text { de empresas } \\
(\%)\end{array}$ & $\begin{array}{c}\text { Pessoal ocupado } \\
(\%)\end{array}$ & $\begin{array}{c}\text { Receita total } \\
(\%)\end{array}$ \\
\hline Indústria & 17 & 44 & 51 \\
Comércio & 56 & 26 & 33 \\
serviços & 27 & 30 & 16 \\
\hline
\end{tabular}

Fonte: Anuário estatístico do Brasil 1997, IBGE.

Tabela 2.5 Dados da indústria de transformação

\begin{tabular}{|c|c|c|c|c|c|c|}
\hline \multirow{2}{*}{$\begin{array}{c}\text { Faixas de pessoal } \\
\text { ocupado }\end{array}$} & \multicolumn{2}{|c|}{$\mathrm{N}^{0}$ de empresas } & \multicolumn{2}{|c|}{ Pessoal ocupado } & \multicolumn{2}{|c|}{ Receita bruta (1000 R\$) } \\
\hline & Qtde & $\%$ & Qtde & $\%$ & Qtde & $\%$ \\
\hline $0-4$ & 138.107 & 57,5 & 262.788 & 4,6 & 6.390 .751 & 2,6 \\
\hline $5-9$ & 42.028 & 17,5 & 275.484 & 4,8 & 4.792 .653 & 1,9 \\
\hline $10-19$ & 26.460 & 11 & 357.942 & 6,3 & 6.545 .681 & 2,6 \\
\hline $20-99$ & 25.165 & 10,5 & 1.041 .200 & 18,3 & 26.575 .039 & 10,6 \\
\hline $0-99$ & 231.760 & 96,5 & 1.937 .414 & 34 & 44.304 .124 & 17,7 \\
\hline $100-499$ & 6.800 & 2,8 & 1.428 .874 & 25 & 58.416 .635 & 23,4 \\
\hline$\geq 500$ & 1.600 & 0,7 & 2.331 .867 & 41 & 147.044 .244 & 58,9 \\
\hline Total & 240.160 & 100 & 5.698 .155 & 100 & 249.765 .003 & 100 \\
\hline
\end{tabular}

Fonte: Anuário estatístico do Brasil 1997, IBGE. 


\subsection{0 desenvolvimento de novos produtos e processos}

Não existe uma definição universalmente aceita para inovação. Em geral, cada autor apresenta uma definição e a maior parte deles tem uma justificativa para sua escolha. Uma pequena amostra das diferentes definições de inovação poderia contar com as seguintes:

- "Um processo de transformar oportunidades em novas idéias e colocá-las em amplo uso prático" (Tidd \& Bessant \& Pavitt, 1997, p.24).

- "Uma idéia, método, ou objeto que é percebido como novo por um indivíduo ou outra unidade de adoção" (Rogers, 1995, p.11).

- "A ferramenta específica dos empreendedores; o meio pelo qual eles exploram a mudança como uma oportunidade para um negócio diferente ou serviço. Capaz de ser apresentada como uma disciplina que pode ser aprendida e praticada" (Drucker, 1985, citado por Tidd, Bessant \& Pavitt, 1997, p. 24).

- "Um processo que inicia com uma invenção, prossegue com o desenvolvimento da invenção e resulta na introdução no mercado de um novo produto, processo ou serviço" (Small Business Administration - SBA, 1998, página da WEB: www.sba.gov).

- "Um processo de geração de novas idéias para suas fontes e tomada de decisões sobre essas idéias, resultando em alguma coisa útil" (Kamm, 1987, p.1).

Desconsiderando as diferenças semânticas, em geral, a inovação é vista como um processo de criação e desenvolvimento de uma idéia que resulta no lançamento de um novo produto e/ou serviço no mercado ou na modificação de um processo produtivo. No âmbito deste trabalho, optou-se por considerar o desenvolvimento de novos produtos e processo produtivo como sinônimo de inovação. Esta assertiva visa apenas a facilidade de exposição da teoria e abordagem da pesquisa.

A inovação, seja ela de caráter tecnológico ou não, envolve muitas dificuldades e barreiras a serem vencidas para ir da sua etapa inicial de criação até a colocação do novo produto no mercado ou o novo processo em operação. Por outro lado, o resultado de uma inovação bem sucedida pode representar a sobrevivência ou liderança de uma empresa e até mesmo alterar os hábitos e comportamentos de uma sociedade. " $A$ inovação é de uma só vez a criadora e a destruidora de setores industriais e corporações" (Utterback, J. M., 1994, p. xiv).

Nem todas as inovações apresentam o mesmo grau de dificuldade no seu desenvolvimento; os resultados para a empresa e o impacto no mercado também variam. Para distinguir as inovações de acordo com a sua importância, Edwards \& Gordon (1984), 
citado por Acs \& Audretsch (1991), criaram uma classificação das inovações por significância, compreendendo quatro classes:

a) A inovação estabeleceu uma categoria totalmente nova de produto;

b) A inovação é a primeira do seu tipo no mercado em uma categoria de produto já existente;

c) A inovação representa uma melhoria significativa na tecnologia existente;

d) A inovação é uma melhoria modesta projetada para modernizar um produto existente.

Outra forma simplificada e bastante utilizada na literatura para classificar as inovações é a separação destas em duas categorias, as radicais ou revolucionárias e as incrementais. A inovação radical representa um produto ou processo inédito no mercado, capaz de revolucionar os hábitos de consumo e transformar seus idealizadores em donos do mercado. Este tipo de inovação ocorre algumas vezes e gera grandes mudanças no mercado, como foi, por exemplo, o caso da geladeira e sua precursora, a máquina de produzir gelo. Esta inovação alterou de forma drástica a vida das pessoas, além de determinar o fim da indústria de extração do gelo, que em meados do século passado, representava uma parcela significativa da economia americana, chegando a exportar sessenta mil toneladas de gelo em $1870^{16}$. Desde 1925, com a introdução no mercado das primeiras geladeiras elétricas, até os dias de hoje, ainda se convive com esta inovação. Mas comparando-se as primeiras geladeiras com os modelos que existem hoje no mercado, verifica-se que as diferenças são enormes. Essas diferenças são o resultado de melhorias implementadas durante mais de setenta anos e representam uma outra forma de inovação, a incremental.

Responsáveis pelo desenvolvimento técnico, redução dos preços e sobrevivência dos produtos, as inovações incrementais ocorrem em grande número, se comparadas às inovações ditas revolucionárias, como a primeira máquina de fazer gelo. Para cada invenção ou inovação revolucionária, provavelmente, existem centenas ou milhares de inovações incrementais.

Robertson (1967), citado por Engel \& Blackwell \& Miniard (1995), propõe uma classificação de acordo com o impacto da inovação no comportamento das pessoas. Para o autor existem três classes de inovações: contínuas, dinamicamente contínuas e descontínuas. A inovação contínua é a modificação de um produto existente, que praticamente não provoca mudança no comportamento das pessoas, como por exemplo, um novo modelo de automóvel. Uma inovação dinamicamente contínua pode ser a

\footnotetext{
${ }^{16}$ Relatado por James M. Utterbaback no livro "Mastering the Dynamics of Innovation" , Boston, 1994, HBS, cap. 7, p.156.
} 
criação de um novo produto ou a modificação de um existente que geralmente não altera a maneira que o usuário compra e utiliza o produto, como uma escova de dente elétrica. Por último, a inovação descontínua é aquela que envolve um produto totalmente novo e que altera significativamente o comportamento dos consumidores, como por exemplo, um forno de microondas.

Freeman (1974), citado por Kay (1979), apresenta uma classificação da inovação relacionada ao grau de incerteza envolvido. Para o autor, as incertezas relacionadas à atividade inovadora podem ser provenientes de três áreas: geral do negócio, mercado e técnica. A incerteza geral do negócio aplica-se a todas decisões relacionadas ao futuro e que podem ser influenciadas pelas variáveis do ambiente, tais como a política, economia, aspectos legais e outros. As outras duas incertezas referem-se ao desempenho do produto e a aceitação deste no mercado. O quadro 2.3 apresenta a classificação proposta por Freeman.

\section{Quadro 2.3 Grau de incerteza associada com vários tipos de inovação}

1. Verdadeira incerteza

2. Grau muito alto de incerteza

3. Alto grau de incerteza

4. Grau moderado de incerteza

5. Grau pequeno de incerteza

6. Grau muito pequeno de incerteza
- Pesquisa fundamental

- Invenção fundamental

- Inovações radicais de produto

- Inovações radicais de processo realizadas externamente à empresa

- Inovações maiores de produto

- Inovações radicais de processo realizadas na própria empresa

- Novas gerações de produtos estabelecidos

- Inovação licenciada

- Imitação de Inovações de produtos

- Modificação de produtos e processos

- Adoção precoce de processo estabelecido

- Novo modelo

- Diferenciação de produto

- Nova função para produto estabelecido

- Adoção tardia de processo estabelecido

- Melhorias técnicas menores

Fonte: Freeman 1974, citado por Kay, 1979, p.19 
Kamm (1987) critica a classificação da inovação quanto ao seu grau de novidade na forma que alguns autores apresentam, considerando esta dimensão como uma variável discreta. Para Kamm, revolucionária e incremental são os dois pontos extremos de uma faixa contínua de pontos que existem na classificação da inovação quanto ao grau de novidade. O quadro 2.4 apresenta a classificação proposta pela autora.

\section{Quadro 2.4 Tipos de inovação: um esquema de classificação}

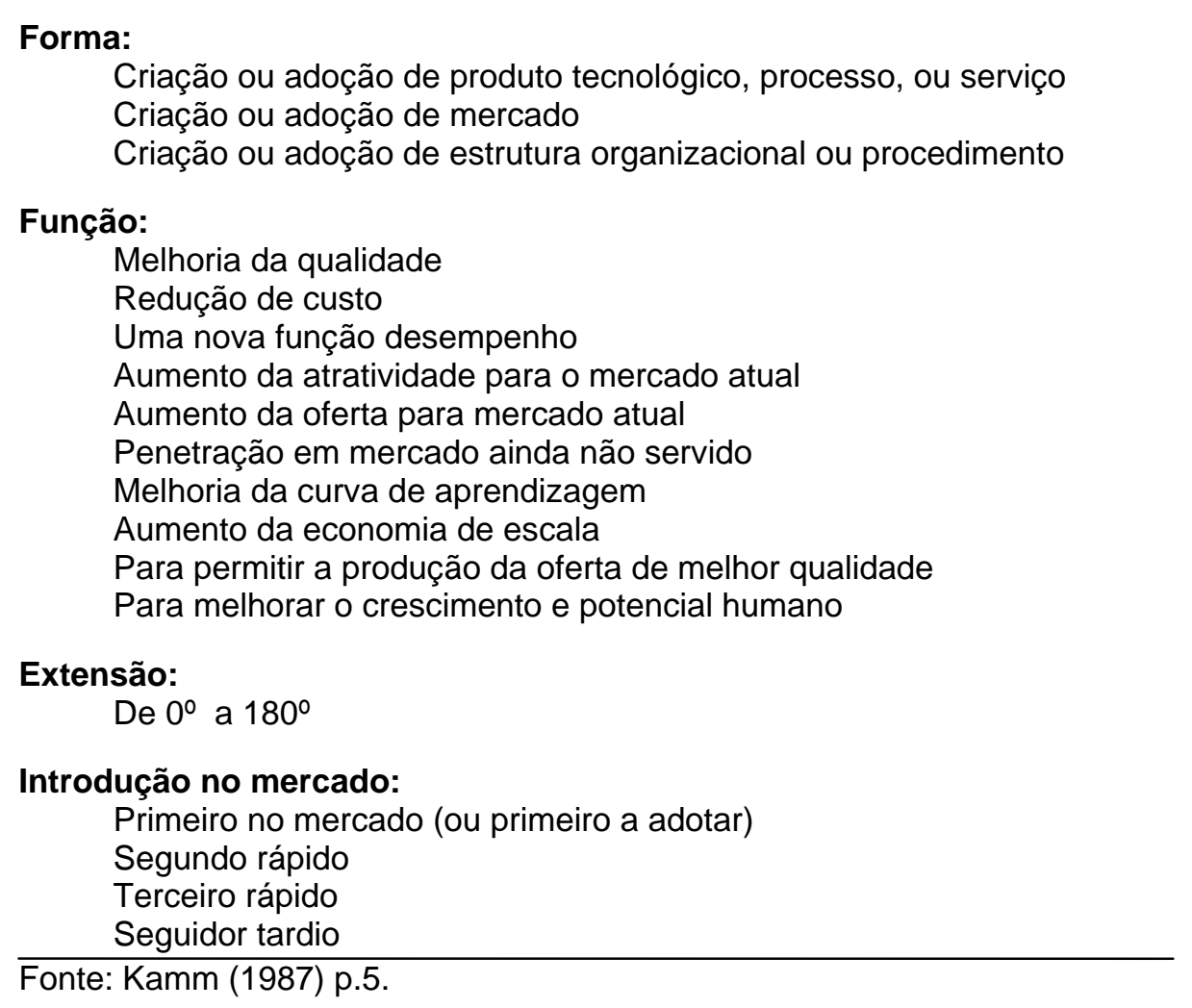

Segundo Kamm (1987), a maior parte das taxionomias sobre inovação apresentam apenas uma ou duas dimensões. Para a autora, existe a necessidade de uma categorização mais abrangente, que permita ao agente que toma decisão, um conhecimento mais preciso sobre o tipo de inovação que está sendo considerado. Nesse sentido, apresenta um esquema de classificação da inovação com quatro dimensões: forma, função, extensão e introdução no mercado.

A dimensão forma é a mais básica na descrição do que é novo. A novidade ocorre em um dos três componentes fundamentais de qualquer organização: a tecnologia, 0 mercado ou na própria organização.

A função de uma inovação é aquilo que a torna útil, o seu propósito.

A dimensão extensão é provavelmente a mais utilizada para identificar e categorizar a inovação. Diferente das dimensões forma e função, que são variáveis discretas ou categóricas, esta dimensão é uma questão de grau de diferença de um ponto de referência, 
o que a torna uma variável ordinal. A figura 2.4 ilustra o conceito da dimensão extensão conforme proposto por Kamm (1987).

\section{Figura 2.4 Extensão da inovação: "Quanto nova é a novidade"}

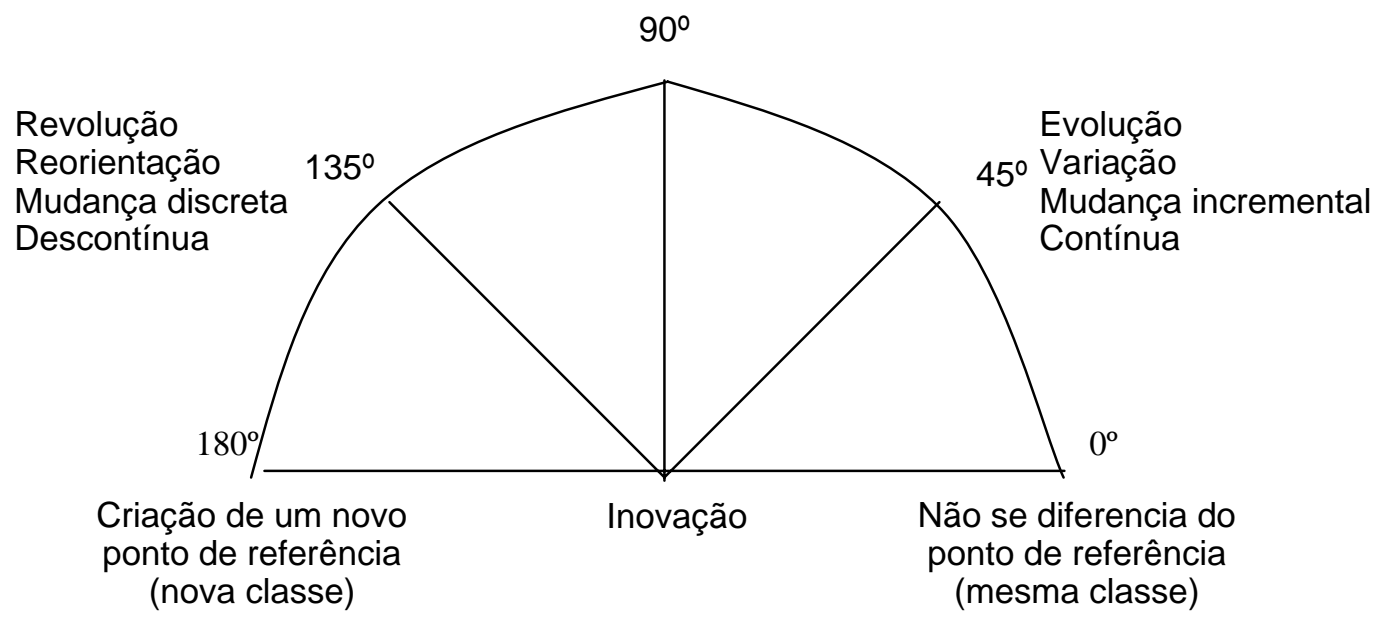

Fonte: Kamm (1987) p.7.

A introdução no mercado marca a disponibilidade ou adoção do novo produto para o mercado. Quanto mais pioneira for a introdução do novo produto, maior a incerteza sobre o seu desempenho e o impacto que causará.

A autora chama a atenção para o quanto é valioso ao tomador de decisão uma classificação da inovação, que abranja várias dimensões. Essa classificação auxilia o tomador de decisão na percepção dos riscos que existem numa decisão que envolve incerteza, como é tipicamente o caso de decisões sobre inovações.

\subsubsection{A Inovação como um processo estratégico}

Para estudar o processo de inovação foram criados inúmeros modelos ao longo do tempo que explicam alguns tipos de inovação, situações, ou são prescritivos para a sua administração. Dada a grande variação que a inovação pode ter quanto à natureza, grau de novidade, mercado de aplicação e outros fatores, torna-se praticamente impossível um modelo que atenda a tantas variações. Em geral, têm surgido na literatura modelos genéricos tratando de partes ou aspectos do processo de inovação.

Um modelo bastante difundido e considerado clássico na literatura sobre inovação, é o do ciclo de vida do produto, desenvolvido por Abernathy \& Utterback (1978), citado por Utterback (1994). Este modelo estabelece que durante a fase inicial da vida de um produto, existe uma efervescência de inovações voltadas para a experimentação do produto. Quando 
os consumidores e produtores tiverem adquirido experiência com as diferentes versões do produto e o conceito do produto estiver formado, surge um projeto dominante. Neste ponto, os produtores adotam o projeto dominante e passam a buscar melhorias no processo com a finalidade de ganhar produtividade e reduzir custos. A figura 2.5 ilustra este modelo.

Figura 2.5 Modelo de inovação de produto e processo

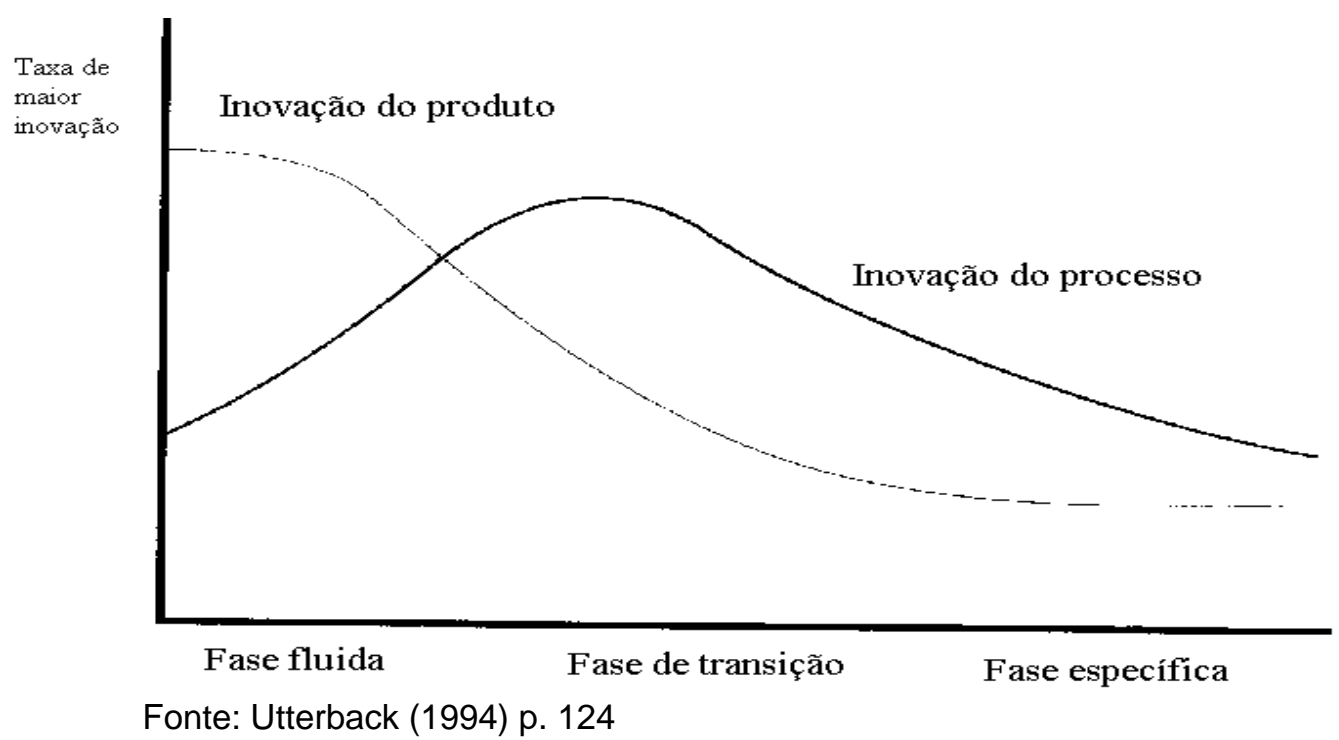

Pisano (1997), pesquisando vinte e três projetos de desenvolvimento de produtos farmacêuticos realizados no período de 1980 a 1993, apresenta alguns comentários sobre o ciclo de vida de produtos:

a) É possível coexistir a capacitação em desenvolvimento de produto e processo numa empresa, de forma simultânea e complementar;

b) O modelo de ciclo de vida assume que não é necessária a inovação especializada em processo para haver a inovação do produto. Na verdade, quando se investe em tecnologia especializada de processo, no caso de algumas empresas farmacêuticas, está se preparando para o desenvolvimento de novos produtos.

Ao invés do ciclo de vida, Pisano propõe um mapeamento do contexto em que se dá o desenvolvimento, considerando diversos setores industriais. A figura 2.6 apresenta este mapeamento na forma de uma matriz. 


\section{Figura 2.6 Relação entre as inovações de produto e processo}

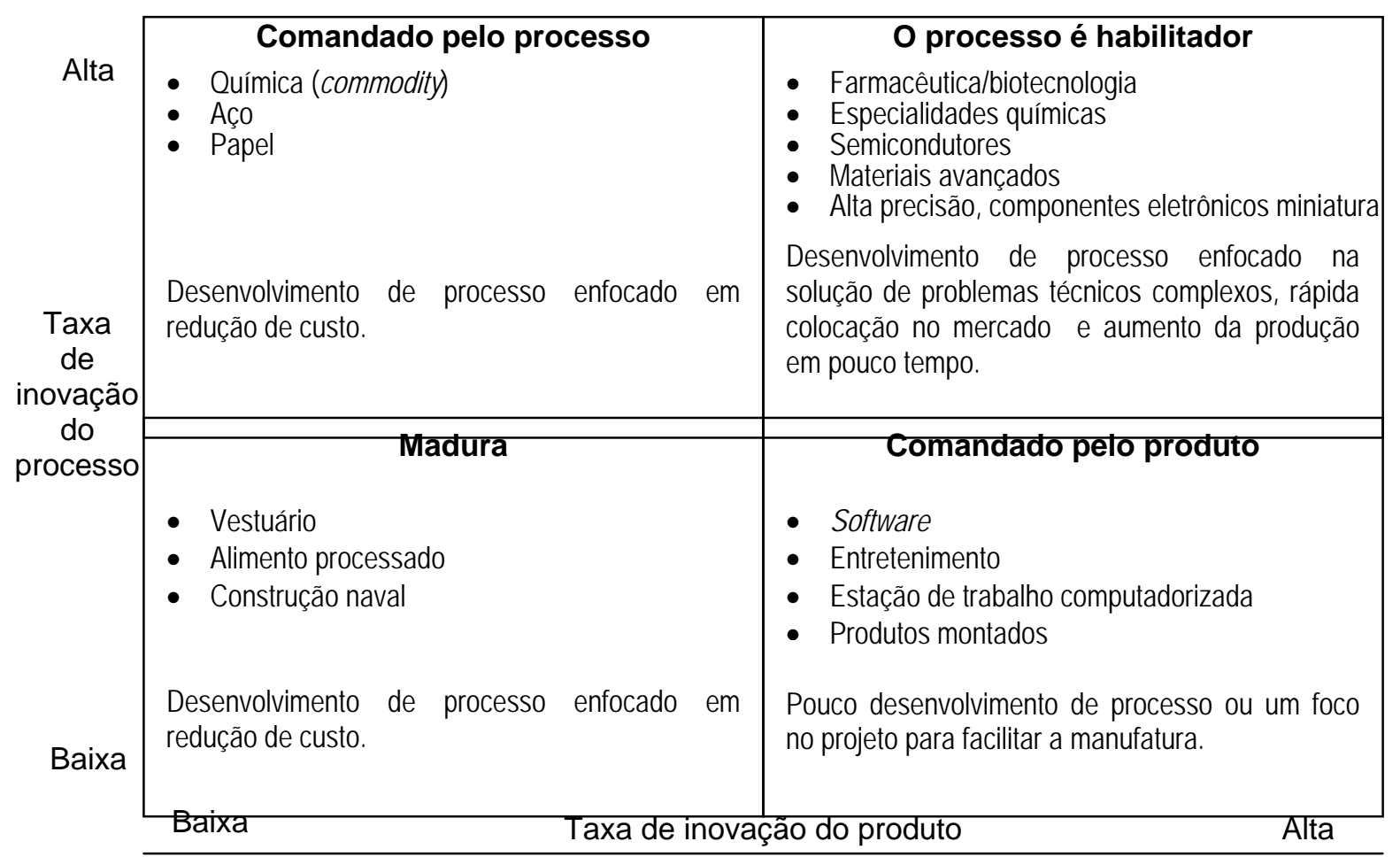

Fonte: Pisano (1997), p.10

Tidd \& Bessant \& Pavitt (1997) identificam dois fatores-chave para o sucesso da inovação: recursos técnicos (pessoas, equipamentos, conhecimento, dinheiro e outros) e a capacitação da empresa para administrar os recursos. Para que a empresa esteja capacitada, os autores propõem que seja implementado um conjunto de rotinas com a finalidade de tornar automática a seqüência de ações relacionadas com o desenvolvimento da inovação. Essas rotinas $^{17}$ formam parte da cultura da empresa e são elas que diferenciam uma organização de outra na forma de administrar.

As rotinas precisam estar integradas a uma extensa lista de competências que juntas formam a capacitação da organização em administrar a inovação.

Com base na análise de diversas pesquisas sobre inovação, os autores apresentam o modelo ilustrado na figura 2.7 .

\footnotetext{
${ }^{17}$ O conceito de rotina, como empregado por Tidd, Bessant \& Pavitt advém da teoria evolucionária da mudança na economia de Nelson e Winter, apresentada no item 2.1.2 deste trabalho.
} 
Figura 2.7 Rotinas que suportam o processo de administração da inovação

\begin{tabular}{|c|c|c|c|c|}
\hline \multirow{3}{*}{$\begin{array}{c}A \\
T \\
1 \\
V \\
1 \\
D \\
A \\
D \\
E \\
S\end{array}$} & FASES & 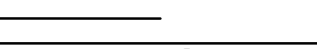 & & \\
\hline & $\begin{array}{l}\text { Processamento } \\
\quad \text { do sinal } \\
\text { Fazer uma varredura } \\
\text { do ambiente para } \\
\text { coletar sinais } \\
\text { tecnológicos, do } \\
\text { mercado e outros } \\
\text { Coletar e filtrar os } \\
\text { sinais contra os } \\
\text { ruídos de fundo } \\
\text { Repetir a varredura } \\
\text { de tempo em tempo } \\
\text { Processar os sinais } \\
\text { em informações } \\
\text { relevantes para a } \\
\text { tomada de decisão }\end{array}$ & $\begin{array}{l}\quad \text { Estratégia } \\
\text { Analisar, escolher, } \\
\text { planejar } \\
\text { Avaliar os sinais em } \\
\text { termo de possibilidades } \\
\text { Fazer a ligação com a } \\
\text { estratééia geral do } \\
\text { negócio } \\
\text { Fazer a ligação com o } \\
\text { conhecimento básico } \\
\text { central - competências } \\
\text { Avaliar custos e } \\
\text { benefícios de diferentes } \\
\text { opções } \\
\text { Selecionar as opções } \\
\text { prioritárias } \\
\text { Ajustar e comprometer } \\
\text { recursos } \\
\text { Planejar }\end{array}$ & \begin{tabular}{l}
\multicolumn{1}{c}{$\begin{array}{c}\text { Alocação de } \\
\text { recursos }\end{array}$} \\
Obter soluções \\
alinhadas com decisões \\
estratégicas \\
Inventar em casa \\
através de P\&D \\
Usar de P\&D existente \\
Adquirir via contrato \\
externo de P\&D \\
Licenciar ou comprar \\
transferir tecnologia
\end{tabular} & $\begin{array}{l}\text { Implementação } \\
\text { Desenvolver para } \\
\text { maturidade } \\
\text { Desenvolver técnica em } \\
\text { paralelo ao } \\
\text { desenvolvimento de } \\
\text { mercado relevante. } \\
\text { Mercado externo de } \\
\text { clientes para } \\
\text { desenvolvimento de } \\
\text { produtos. } \\
\text { Mercado interno de } \\
\text { usuários para } \\
\text { desenvolvimento de } \\
\text { processos. } \\
\text { Lançar e comissionar } \\
\text { Dar suporte após venda }\end{array}$ \\
\hline & & Planejar & e re-inovação & \\
\hline
\end{tabular}

Fonte: Tidd, Bessant \& Pavitt (1997), p. 41.

Clark \& Wheelwright (1993), analisando a administração do desenvolvimento de novos produtos e processos, observam que os principais problemas nesta área são decorrentes de dois fatos: a) o desacordo entre a atenção do gerente senior, que em geral ocorre na fase final do projeto de desenvolvimento, e a influência desse gerente, que é mais alta e efetiva nos estágios iniciais do projeto; b) o desalinhamento entre o planejamento estratégico do negócio e o conjunto de projetos que a empresa tem em andamento.

Com base na experiência de vários projetos desenvolvidos em empresas de diversos setores industriais, Clark \& Weelwright (1993) relacionaram seis armadilhas que surgem com grande freqüência no desenvolvimento dos projetos:

1) O alvo móvel - acontece algumas vezes de haver uma mudança no conceito básico do produto ou processo em desenvolvimento. Isso pode ser causado pela adoção de uma tecnologia ainda não estável ou devido a alguma alteração no mercado. Uma vez iniciada a mudança de alvo, os problemas se avolumam; o projeto se atrasa e provavelmente novas mudanças ocorrerão. 
2) Desacordo entre funções - enquanto o alvo móvel habitualmente reflete um desacordo entre a organização e o ambiente externo, também pode ocorrer um desacordo interno à empresa. Nem sempre áreas como engenharia, marketing e produção estão compartilhando a mesma concepção de produto.

3) Falta de características distintivas no produto - é comum acontecer um desapontamento quando o projeto chega ao fim. O produto que se imaginava no início do desenvolvimento como sendo diferenciado, torna-se bastante comum quando o desenvolvimento chega ao final. Uma possível causa para este fato é a adoção muito rápida de um conceito sem uma análise mais cuidadosa de outras alternativas.

4) Problemas técnicos inesperados - atrasos e custos acima do planejado acontecem freqüentemente devido a avaliações superestimadas da capacidade técnica da equipe ou a alguma perda de recurso.

5) Atrasos na solução de problemas - o desenvolvimento de produtos e processos envolve uma grande dose de incerteza, tanto em relação aos problemas específicos como quanto aos conflitos que surgem na alocação dos recursos. Com o atraso do projeto, surgem as pressões e a perda do controle de custo.

6) Questões políticas não resolvidas - muitas escolhas e decisões são feitas durante o desenvolvimento do projeto. Caso as políticas maiores da empresa não estejam estabelecidas de forma clara, fatalmente vão acontecer debates envolvendo grande parte da organização, o que deve causar atrasos e outros problemas.

Por outro lado, os autores relacionam três tipos de benefícios que a empresa recebe quando realiza um projeto de desenvolvimento adequadamente. O primeiro é a posição no mercado, que pode ser a abertura de um novo mercado ou alcançar um padrão de referência no setor. Nos dois casos existe a criação de uma barreira com os competidores e provavelmente o aumento da participação no mercado. Segundo, é o benefício de antecipar os ganhos da utilização dos recursos. O terceiro e talvez o mais interessante é a possibilidade de renovar e transformar a organização.

Clark \& Weelwright (1993) comentam que muitas empresas cometem um engano quando convertem os dois elementos críticos do desenvolvimento, o plano para tecnologia e o plano de posicionamento de mercado do produto, em projetos individuais. Os autores argumentam que este tipo de estrutura não aproveita os recursos adequadamente e não facilita a renovação da organização. A figura 2.8 exprime a estrutura recomendada pelos autores para o desenvolvimento de estratégia. 
Figura 2.8 Estrutura para desenvolvimento da estratégia

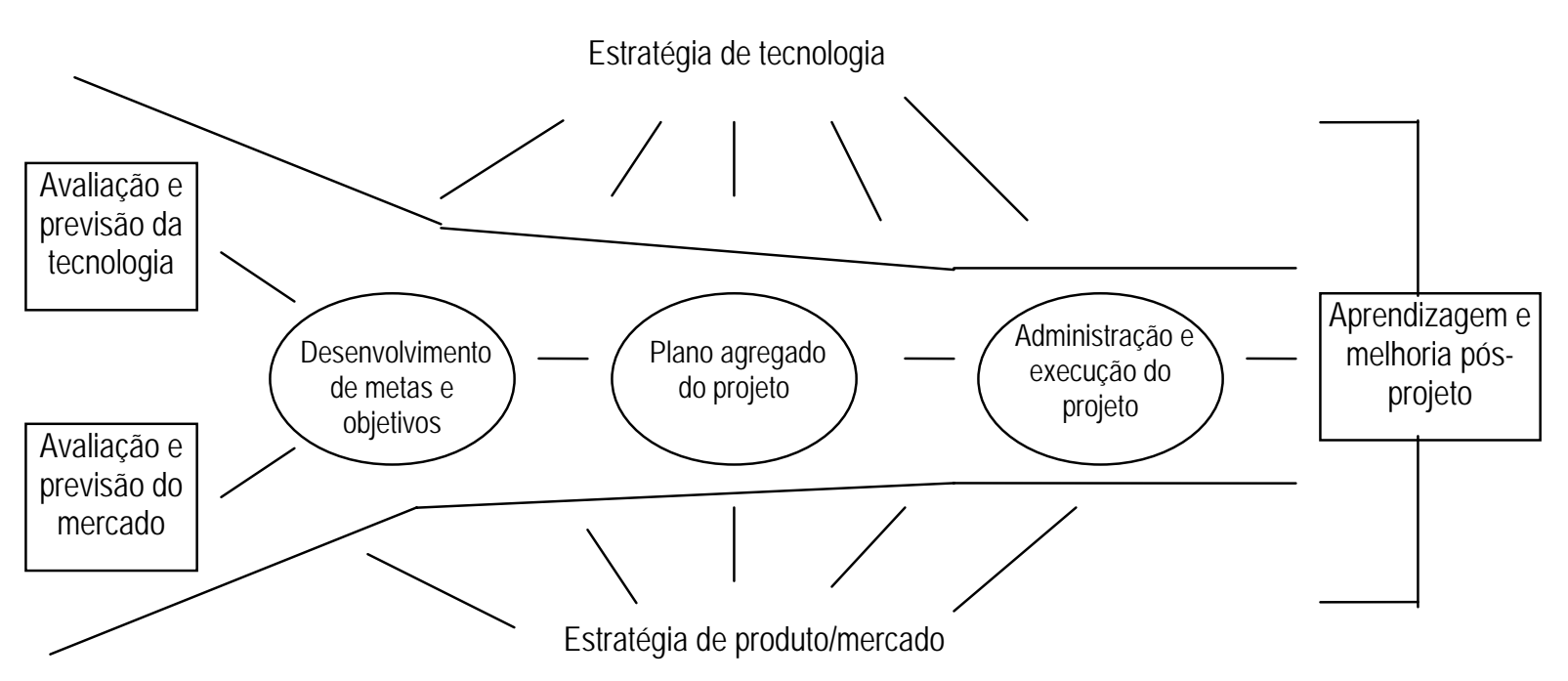

Fonte: Clark \& Weelwright (1993), p. 90.

Alguns autores, como Gary Hamel, C. K. Prahalad e Dorothy Leonard-Barton têm dado ênfase ao conhecimento central ${ }^{18}$ da organização como fator fundamental na elaboração da estratégia competitiva. Hamel \& Prahalad (1994) argumentam que a vantagem competitiva sustentada é criada pela competência central da empresa e não por seus produtos, que são os resultados visíveis dessa competência. Para que o conceito de competência central seja absorvido e crie raízes na organização, segundo os autores, é necessário que o corpo gerencial entenda e participe de cinco tarefas básicas: 1) identificar as competências centrais existentes; 2) estabelecer um programa para aquisição de novas competências centrais; 3) construir as novas competências centrais; 4) reorganizar as competências centrais; 5) proteger as lideranças nas competências centrais.

Leonard-Barton (1998) define a capacitação central como o conhecimento desenvolvido pela empresa ao longo do tempo, que traz a vantagem competitiva e não permite ser imitado. A autora chama a atenção para a existência de outros graus de capacitação, que são necessários para o bom desempenho da empresa, mas não constituem a capacitação central. Assim, o grau de importância das capacitações suplementar e habilitadora, disponíveis no mercado, são de baixa importância estratégica, enquanto a capacitação central não disponível é fundamental.

\footnotetext{
${ }^{18}$ Hamel \& Prahalad (1994) utilizam o termo "core competence", enquanto Leonard-Barton (1998) utiliza "core capabilities".
} 


\subsubsection{O sucesso e o fracasso em inovações}

Uma das formas utilizadas para se estudar a administração da inovação, bem como outras tantas áreas do conhecimento, é o esclarecimento do fenômeno através das relações entre causa e efeito. Nesse sentido, uma das principais preocupações dos pesquisadores tem sido a busca dos fatores determinantes do sucesso ou fracasso da inovação. Essa questão gerou algumas controvérsias e outras dúvidas recorrentes, como por exemplo, a definição de sucesso e fracasso e como medir esses resultados.

Tidd \& Bessant \& Pavitt (1997) observam que é necessário considerar a perspectiva de tempo na definição do sucesso ou fracasso de uma inovação. Os autores argumentam que não basta o sucesso a curto prazo e sim, o crescimento sustentado da empresa através da invenção e adaptação contínua. Nesta concepção, o sucesso está relacionado ao processo total de inovação e na sua capacidade de contribuir consistentemente para o crescimento da empresa.

Segundo Kamm (1987), o resultado de uma inovação vai muito além da questão dicotômica de sucesso ou fracasso e a sua análise pode levar em conta um número quase infinito de dimensões. Qualquer tipo de inovação, por definição, resulta em algum tipo de mudança e o resultado dessa mudança, que pode variar em escopo e grau, afeta não somente a empresa autora da inovação, mas também o ambiente. Para a autora, uma forma de se avaliar o mérito de uma inovação é através da análise de quanto as implicações desta inovação afetaram, positiva ou negativamente, a sua fonte e o ambiente. Essa consideração, no entanto, não invalida a adoção de indicadores do resultado da inovação; ao contrário, Kamm (1987) propõe que se meça o quanto foi alcançado dos objetivos estabelecidos. O retorno sobre o investimento, a participação no mercado, a redução do custo e tantos outros indicadores podem ser utilizados para se avaliar o quanto do objetivo foi conquistado pelo autor da inovação.

A idéia de sucesso ou fracasso de uma inovação, além de servir para análise das possíveis causas do resultado obtido, também pode ser aplicada na metodologia de pesquisa. O projeto SAPPHO ${ }^{19}$ foi uma pesquisa que utilizou a idéia de sucesso e fracasso como método para testar diversas hipóteses sobre inovações. O propósito desse projeto foi tentar substanciar ou refutar algumas generalizações sobre as inovações técnicas através da comparação sistemática de pares de tentativas de inovação. Cada par representava uma tentativa com sucesso e uma com fracasso.

${ }^{19}$ O projeto SAPPHO foi originalmente planejado em 1968 por R. C. Curnow e R. Rothwell. Este projeto de pesquisa foi posteriormente implementado pelo SPRU (Science Policy Research Unit) da Universidade de Sussex, na década de setenta (Freeman \& Soete, 1997, p.204). 
Segundo Freeman \& Soete (1997), o primeiro estágio da pesquisa SAPPHO estudou cinqüenta e oito tentativas de inovações do setor químico e de instrumentos científicos. As inovações do setor químico eram, na grande maioria, relativas ao processo de produção, enquanto as do setor de instrumentos científicos eram todas relativas a produto. Colocando-se as tentativas de inovação em pares esperava-se discriminar entre as respectivas características de falha e de sucesso. Quando as duas metades do par diferissem a respeito de uma determinada característica, estariam indicando uma possível explicação do sucesso ou falha da inovação. Esse processo repetido com um significante número de pares, pode fornecer a evidência sistemática para a validade de uma hipótese. Posteriormente, fez-se uma análise de similaridade, que permite a identificação de algumas características que são comuns às empresas tentando inovar. Essa análise complementar também permite focalizar a atenção nas características, que não divergem entre sucesso e falha.

No projeto SAPPHO, segundo Freeman \& Soete (1997), o critério utilizado para definir o sucesso e fracasso foi estabelecido com base comercial. O fracasso foi considerado uma tentativa de inovação que falhou ao estabelecer um mercado que valesse a pena e/ou fizesse algum lucro, ainda que tenha funcionado no sentido técnico. O sucesso é uma inovação que conseguiu uma penetração significante no mercado e/ou tenha feito algum lucro.

No desenvolvimento da pesquisa foram feitas aproximadamente duzentas medidas, comparativas ou absolutas, em cada caso de sucesso e falha. Dessas medidas, apenas uma pequena parcela se diferenciou claramente entre o sucesso e o fracasso. As principais conclusões da pesquisa foram:

- Tamanho da empresa, tamanho do departamento de P\&D e número de profissionais especializados não comprovaram estar relacionados com sucesso;

- Contrariamente a algumas teorias, não houve associação entre falha e a tentativa de inovar em áreas não familiar para a empresa;

- Não houve discriminação entre falha e sucesso para a taxa de crescimento da empresa e competitividade do ambiente;

- As tentativas com sucesso se distinguiram freqüentemente das falhas apenas nos seguintes aspectos: maior atenção para a educação do usuário, publicidade, previsões de mercado e compreensão dos requisitos do usuário. 
Segundo Freeman \& Soete (1997), na mesma época do projeto SAPPHO foi realizado na Inglaterra outro estudo com uma grande série de casos de inovação industrial, onde os autores concluíram:

\begin{abstract}
Possivelmente, a generalização de mais alto nível e segura que se possa fazer sobre inovações tecnológicas é que elas devem envolver a síntese de algum tipo de necessidade com algum tipo de possibilidade técnica. A maneira como esta síntese é efetuada e explorada pode tomar muitas formas diferentes e não depende somente do planejamento sistemático e do "estado da arte", mas também de motivações individuais, pressões organizacionais e influências externas de caráter político, social e econômico. Devido à extensão do processo de inovação ao longo do tempo, é importante manter uma contínua sensibilidade às mudanças desses fatores e a flexibilidade para perceber e responder às novas oportunidades (Langrish et al., 1972, p. 200, citado por Freeman \& Soete, 1997, p. 218).
\end{abstract}

\title{
2.4.3 Tecnologia e custo da inovação
}

Segundo a enciclopédia Larousse (1998), a palavra tecnologia tem sua origem no grego, tekhnologia e apresenta o seguinte significado:

\begin{abstract}
"A tecnologia abrange o estudo sistemático do trabalho humano em seus múltiplos aspectos: o estudo dos materiais sobre os quais ele incide, o dos utensílios, ferramentas, máquinas, instrumentos e da energia através dos quais se efetiva a transformação dos materiais submetidos ao trabalho. A tecnologia implica o emprego de métodos, além dos que Ihe são próprios, oriundos das ciências físicas e naturais, das matemáticas e dos mais diversos ramos do conhecimento humano. [...] Colocada nestes termos, a tecnologia é a disciplina científica que tem como objeto a produção" (p.5612).
\end{abstract}

A própria enciclopédia, no entanto, salienta que esta concepção de tecnologia está longe de representar consenso entre os autores que vêm se dedicando ao assunto. Se não existe consenso quanto ao significado da tecnologia, maior ainda é a discordância da visão sobre o impacto dela no desenvolvimento e na sociedade, de forma geral.

Kruglianskas (1996) adota um conceito amplo de tecnologia, considerando-a como o conjunto de conhecimentos necessários para se conceber, produzir e distribuir bens e serviços de forma competitiva. Nesse conceito, o autor ressalta dois aspectos importantes da tecnologia: 1) seu caráter multi-funcional, abrangendo todas as áreas da empresa; 2) a sua característica temporal, isto é, a tecnologia existe enquanto contribui para a competitividade da empresa.

Almeida (1981), citado por Kruglianskas (1996), apresenta uma classificação da tecnologia, que leva em conta o nível de explicitação do conhecimento. De acordo com esta classificação, a tecnologia pode ser: implícita, explícita ou embutida.

A tecnologia implícita é aquela que está incorporada nas pessoas da organização e não se apresenta embutida nos produtos. O acesso a esse tipo de tecnologia só é possível por meio das pessoas que possuem o conhecimento. 
A tecnologia explícita caracteriza-se por não estar embutida em produtos e nem incorporada nas pessoas. Esse tipo de tecnologia, em geral, não fornece as informações completas para o domínio do assunto e está disponível em documentos.

Quando a tecnologia não está incorporada nas pessoas da organização, mas se encontra embutida nos produtos, é chamada de tecnologia embutida. Neste caso, o acesso à tecnologia pode ser obtido por meio de técnicas apropriadas, como por exemplo, a análise de laboratório.

O quadro 2.5 ilustra a classificação da tecnologia apresentada.

\section{Quadro 2.5 Classificação da tecnologia quanto ao grau de explicitação}

\begin{tabular}{|l|c|c|}
\hline & $\begin{array}{c}\text { Tecnologia incorporada } \\
\text { na(s) pessoa(s) da } \\
\text { organização }\end{array}$ & $\begin{array}{c}\text { Tecnologia não } \\
\text { incorporada na(s) } \\
\text { pessoa(s) da organização }\end{array}$ \\
\hline $\begin{array}{l}\text { Tecnologia embutida em } \\
\text { produtos }\end{array}$ & - & Tecnologia Embutida \\
\hline $\begin{array}{l}\text { Tecnologia não embutida } \\
\text { em produtos }\end{array}$ & Tecnologia Implícita & Tecnologia Explícita \\
\hline
\end{tabular}

De acordo com a classificação apresentada, quando a tecnologia está incorporada nas pessoas da organização e também se encontra embutida nos produtos (quadrante superior esquerdo) não recebe uma denominação específica. Neste caso, segundo Kruglianskas (1996), é possível o acesso parcial ou total à tecnologia, não obstante a mesma ainda não se encontrar disponível em base documental estruturada.

Existe uma associação natural em uma parte significativa da literatura, entre ciência, inovação e tecnologia, permitindo, algumas vezes, que se considere a inovação como o resultado do desenvolvimento tecnológico. Diversas inovações surgem no rastro de novas tecnologias, todavia, a inovação em si não depende obrigatoriamente de nova tecnologia para surgir, embora não seja incomum isso ocorrer. Quanto à relação entre ciência e tecnologia, Derek Price (1965), citado por Freeman \& Soete (1997), apresenta o seguinte comentário:

São dois corpos do conhecimento que foram criados por profissões distintas, de formas bem diferentes e com largas tradições de independência. A comunidade científica esteve interessada em descobertas e na publicação do novo conhecimento em um formato que atendesse o critério profissional dos seus colegas cientistas. A aplicação foi de importância secundária ou nem mesmo foi considerada. Para os engenheiros ou tecnólogos, por outro lado, a publicação foi de importância secundária ou desprezível. Seus interesses 
prioritários foram com a aplicação prática e o reconhecimento profissional que vem com a demonstração de um dispositivo funcionando ou projetado (Freeman \& Soete, 1997, p. 15).

Apesar da tecnologia, no seu sentido mais amplo, existir desde os primórdios da humanidade, tem havido, nas últimas décadas, uma mudança importante na forma de organizar e utilizar o conhecimento de técnicas aplicadas à produção, distribuição e transporte de produtos. A distinção entre as tecnologias primitivas e a moderna não se prende somente a uma questão de escala, envolve também uma mudança fundamental na relação entre a sociedade e a tecnologia. Durante o século vinte, houve a mudança estrutural na forma como a atividade inventiva é desenvolvida, passando do esforço e genialidade de um indivíduo para a pesquisa profissional realizada em laboratórios situados nas indústrias, governo ou academia (Freeman \& Soete, 1997).

Grande parte das invenções e conseqüentes inovações surgidas com a aplicação da tecnologia moderna foram descobertas dentro dos laboratórios ou centros de pesquisa e desenvolvimento (conhecido como P\&D em português ou , Research and Development, $R \& D$, em inglês) e aparentemente só foram possíveis devido à concentração de recursos disponíveis nesses laboratórios.

A complexidade de algumas pesquisas inviabilizam o seu desenvolvimento fora desses centros de P\&D; conforme comentado por Freeman \& Soete (1997):

Ligações íntimas com pesquisa básica através de um meio ou outro foram normais para R\&D nestas indústrias e sua tecnologia é baseada em ciência no sentido que não teria sido desenvolvida sem os fundamentos nos princípios teóricos. Este corpo de conhecimento (química macromolecular, físico-química, física nuclear e eletrônica) nunca poderia ter surgido da observação casual, da habilidade de um artífice ou da tentativa e erro nos sistemas de produção, como foi o caso com diversas tecnologias anteriores. O mesmo é verdade da recente biotecnologia ( p. 198).

Esta nova concepção de desenvolvimento tecnológico, chamada de moderna tecnologia ou alta tecnologia, provocou e ainda está provocando grandes mudanças na sociedade, que vão desde novas estratégias das empresas e chegando até o cotidiano dos consumidores. A ciência ou pesquisa básica que antes pertencia, na sua maioria, aos governos e universidades e portanto, mantinha-se razoavelmente distante e independente do mercado, com a moderna tecnologia e os grandes centros de P\&D, foi se tornando parte da estratégia das grandes empresas, ficando assim mais dependente do aspecto mercantil.

As teorias que tratam do desenvolvimento tecnológico, segundo Dosi (1984), seguem dois caminhos. Um que entende as forças do mercado como o principal indutor das mudanças tecnológicas e o segundo, que considera a tecnologia como um fator autônomo ou quase autônomo. Essas correntes são chamadas respectivamente de "puxada pela demanda" (demand-pull) e "empurrada pela ciência" (science-push). 
Segundo Freeman \& Soete (1997), a inovação é uma junção dos dois lados numa só atividade. Existem inúmeros exemplos de inovações desenvolvidas apenas com a participação dos cientistas, como o espectrômetro de absorção atômica, assim como os exemplos de inovações puxadas pela demanda são muitos, chegando no caso extremo da inovação ser o desenvolvimento de um novo mercado para um produto existente.

Um dos desafios da administração da inovação reside exatamente no fato de se conseguir conjugar os dois fatores essenciais para o seu desenvolvimento, a tecnologia e o mercado, que por sua vez estão continuamente sofrendo mudanças, gerando um leque de opções e incertezas.

Uma forma de se aprofundar o conhecimento sobre o processo de inovação, segundo Mansfield \& Rapoport (1975), é através da análise do custo das diversas fases deste processo. Nesse sentido, os autores analisaram trinta e oito inovações e apresentaram algumas conclusões sobre o custo da inovação:

- Os economistas, algumas vezes, têm assumido que o gasto com P\&D pode ser tratado como sinônimo de custo de inovação. No entanto, os gastos com P\&D são somente uma parte, e algumas vezes uma pequena parte, do custo total de uma inovação;

- As evidências disponíveis sugerem que freqüentemente custa mais para uma grande empresa do que para uma pequena desenvolver o mesmo produto;

- As inovações mais importantes _ aquelas envolvendo novos produtos que atendem um grande mercado _ requerem, em média,uma proporção maior dos seus custos em P\&D.

Um outro estudo que abordou a questão do custo de desenvolvimento de novos produtos e processos foi apresentado por Archibugi \& Evangelista \& Simonetti (1993). Neste estudo foram utilizados os dados de uma pesquisa realizada na Itália com 8.220 indústrias pelo Conselho Nacional de Pesquisa da Itália em conjunto com o Instituto nacional de Estatística (CNR-INSTAT). A tabela 2.6 apresenta um resumo da base de dados utilizada neste estudo. 
Tabela 2.6 Decomposição do custo de inovação por tamanho de empresa

\begin{tabular}{lccccc}
\hline $\begin{array}{l}\text { No de } \\
\text { empregados }\end{array}$ & P\&D & $\begin{array}{c}\text { Projeto e } \\
\text { engenharia }\end{array}$ & $\begin{array}{c}\text { Investimento em } \\
\text { produção }\end{array}$ & Marketing & Total \\
\hline $20-49$ & 7,4 & 15,1 & 73,1 & 4,4 & 100 \\
$50-99$ & 9,6 & 17,5 & 68,2 & 4,7 & 100 \\
$100-199$ & 10,6 & 18,3 & 66,2 & 4,9 & 100 \\
$200-499$ & 14,3 & 16,1 & 64,2 & 5,4 & 100 \\
500 ou mais & 21,4 & 29,5 & 43,5 & 5,6 & 100 \\
Total & 17,9 & 25,2 & 51,5 & 5,4 & 100 \\
\hline Fonte: CNR-ISTAT amostra de 8,220 empresas, citado por Archibugi \& Evangelista \& Simonetti, 1993, p. 8
\end{tabular}

Os dados da tabela 2.6 sugerem que a distribuição do custo da inovação em suas diversas fases é substancialmente diferente entre as pequenas e grandes empresas. Enquanto o custo de P\&D na pequena empresa representa algo entre 7,4\% e 9,6\% do custo total da inovação, na média empresa esse valor sobe para algo entre 10,6\% e 14,3\% e a grande empresa apresenta um valor bem superior, de 21,4\%. Fenômeno semelhante, mas com diferenças menores, ocorre com o custo de projeto e engenharia. Por outro lado, o custo do investimento em produção tem uma participação no custo total da inovação significativamente maior na pequena empresa do que na grande. 


\subsubsection{O processo de inovação na pequena empresa}

A maior parte da análise sobre administração da inovação e os modelos desenvolvidos foram baseados em estudos e pesquisas realizadas com as grandes empresas. Em geral, as pequenas empresas aparecem na literatura sobre inovações apenas em observações esparsas ou artigos específicos. Algumas obras, como "Innovation and Small Firms" de Acs \& Audretsch (1991) ou "Innovation and the small and medium sized firm." de Rothwell \& Zegveld (1983), em geral, abordam diferentes aspectos da inovação, mas sem a concentração no processo de administração.

As duas exceções encontradas na pesquisa bibliográfica, de obras que abordam a administração da inovação na pequena empresa dos setores tradicionais ${ }^{1}$, ficaram por conta de Kruglianskas (1996) e Tidd \& Bessant \& Pavitt (1997). Essa última, apesar de não tratar especificamente da pequena empresa, reserva algumas páginas do livro para abordar a pequena empresa.

O processo de inovação na pequena empresa é fortemente influenciado pelos fornecedores e clientes. Em geral, essa influência se dá através do contato pessoal entre as empresas e é reforçado pela proximidade geográfica. Tal fato permite inferir que a pequena empresa é muito mais susceptível ao contexto regional no qual se insere do que a grande empresa (Tidd \& Bessant \& Pavitt, 1997).

Kruglianskas (1996) apresenta um modelo de como se dá a inovação no contexto das pequenas e médias empresas, ao qual denominou de modelo paralelo do processo de inovação, apresentado na figura 2.9. Segundo este modelo, o processo de inovação se inicia interna ou externamente à empresa e tem continuidade através das diversas etapas, utilizando-se dos conhecimentos científicos e tecnológicos disponíveis, bem como procurando atender às necessidades e aspirações da sociedade. Cabe ressaltar, que em geral, apenas as inovações incrementais se mostram viáveis para a pequena empresa tradicional, descartando-se as do tipo complexas e as radicais.

\footnotetext{
${ }^{1} \mathrm{O}$ termo tradicional foi utilizado para distinguir as empresas que não são de base tecnológica, isto é, intensivas em tecnologias avançadas, conforme empregado por Kruglianskas, 1996, p.5.
} 
Figura 2.9 Modelo paralelo do processo de inovação tecnológica

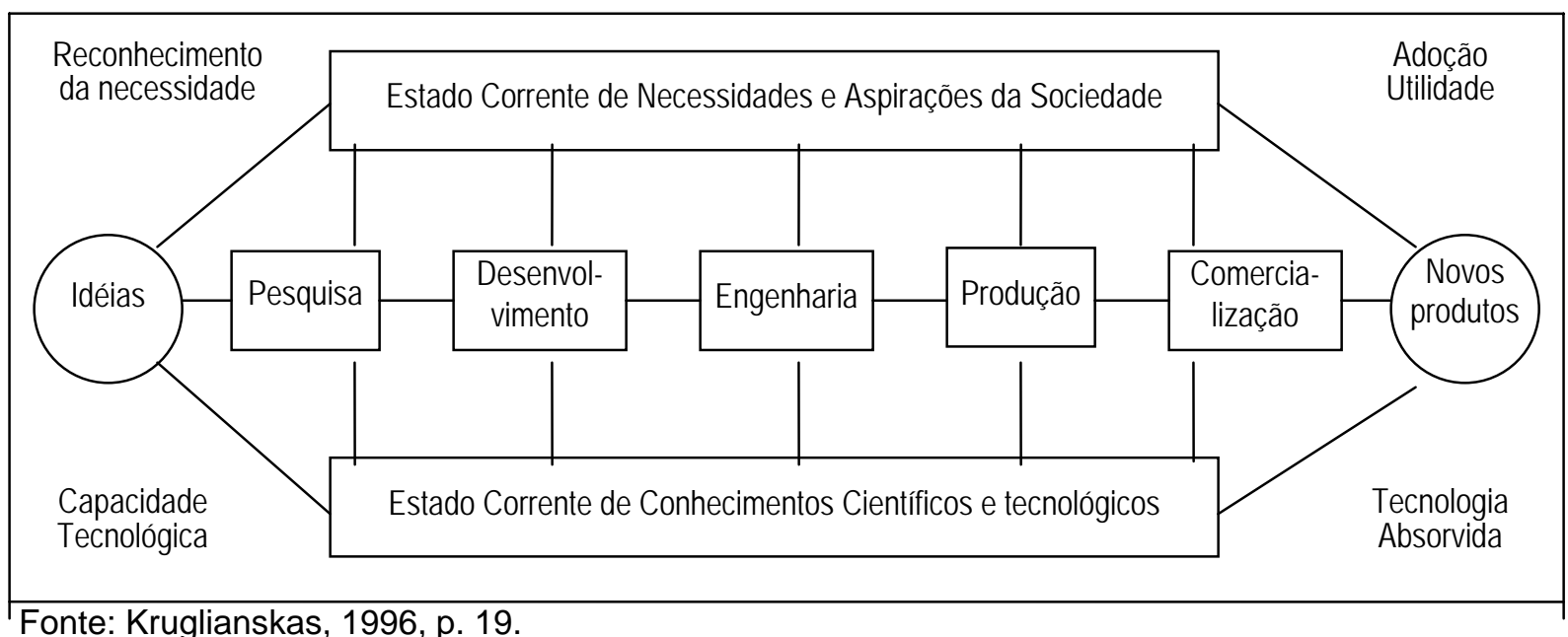

Com base em uma pesquisa realizada no Canadá, abrangendo mil e quinhentas pequenas indústrias inovadoras com quarenta e quatro funcionários, em média, e um faturamento anual médio de \$6,6 milhões de dólares canadenses, Baldwin (1994), citado por Tidd \& Bessant \& Pavitt (1997), apresenta algumas evidências sobre a inovação na pequena empresa :

- As maiores fontes de inovação são os clientes, os fornecedores e a equipe interna de gerentes;

- P\&D formal foi considerado menos importante;

- Os principais fatores que contribuem para o crescimento da empresa são a habilidade em administração, a mão-de-obra e marketing;

- As competências que diferenciam uma empresa inovadora são a qualidade do produto, a flexibilidade e o serviço aos clientes.

Segundo Tidd \& Bessant \& Pavitt (1997), a integração das funções técnicas com produção, marketing e a estratégia da empresa é mais valorizada na grande empresa. $O$ processo de inovação na pequena empresa, em geral, conta com menos funções especializadas e as distâncias físicas e organizacionais são muito menores, o que , em geral, torna suas relações informais. Os procedimento formais e o desenho da estrutura organizacional são importantes fatores para a integração do conhecimento nas grandes empresas. Por outro lado, nas pequenas empresas, as características dos gerentes têm um peso maior nesta integração. Kruglianskas (1996) reforça esta idéia acrescentando que, em geral, o custo de um departamento formal de P\&D é proibitivo para a pequena empresa, mas que essa atividade pode ser realizada de forma compartilhada com as outras áreas. O quadro 2.6 apresenta as diferenças de como o processo de inovação flui na grande e pequena empresa. 


\section{Quadro 2.6 As tarefas estratégicas da inovação na pequena e grande empresa}

\begin{tabular}{|c|c|c|}
\hline TAREFAS ESTRATÉGICAS & GRANDE EMPRESA & PEQUENA EMPRESA \\
\hline $\begin{array}{l}\text { Integrar a tecnologia com } \\
\text { produção e marketing }\end{array}$ & $\begin{array}{l}\text { - Desenho organizacional } \\
\text { - O processo organizacional do } \\
\text { conhecimento flui através das } \\
\text { fronteiras }\end{array}$ & $\begin{array}{l}\text { - Responsabilidade do gerente } \\
\text { senior }\end{array}$ \\
\hline $\begin{array}{l}\text { Monitorar e assimilar novos } \\
\text { conhecimento técnicos }\end{array}$ & -P\&D próprio e redes externas & $\begin{array}{l}\text { - Periódicos técnicos e } \\
\text { comerciais } \\
\text { - Treinamento e serviço de } \\
\text { assessoria } \\
\text { - Consultores } \\
\text { - Fornecedores e clientes }\end{array}$ \\
\hline $\begin{array}{l}\text { Avaliar os benefícios do } \\
\text { aprendizado resultante de } \\
\text { investimentos em tecnologia }\end{array}$ & $\begin{array}{l}\text { - Julgamento baseado em } \\
\text { procedimentos e critérios } \\
\text { formais }\end{array}$ & $\begin{array}{l}\text { - Julgamento baseado nas } \\
\text { qualificações e experiência do } \\
\text { gerente senior }\end{array}$ \\
\hline $\begin{array}{l}\text { Unir o estilo estratégico com as } \\
\text { oportunidades tecnológicas }\end{array}$ & -Desenho organizacional & $\begin{array}{l}\text { - Qualificação dos gerentes e } \\
\text { equipe }\end{array}$ \\
\hline
\end{tabular}

Fonte: Tidd \& Bessant \& Pavitt, 1997, p.156

Com base em uma pesquisa realizada com os principais dirigentes de 39 pequenas e médias empresas (PMEs) de diversos setores, Kruglianskas (1996) apresenta os principais problemas apontados por estes dirigentes nas áreas de alta administração, marketing, recursos humanos e tecnologia:

- Planejamento estratégico

- Prontidão para enfrentar mudanças nos negócios

- Ameaça da concorrência

- Falta de agressividade e eficiência dos vendedores

- Treinamento do pessoal

- Contratação e substituição de funcionários

- Participação em feiras e exposições

- Otimização dos processos produtivos

- Contato com universidades e institutos de pesquisa 


\subsection{A tomada de decisão aplicada à administração da inovação}

Tomar decisão faz parte de qualquer atividade humana, desde a mais simples e rotineira ação individual, até o mais complexo projeto empreendido por grandes corporações. Em cada caso existem diferentes problemas envolvidos e diferentes graus de dificuldade para se tomar decisão. Segundo Cury (1983), existe duas formas típicas de se tomar decisões nas empresas: a) o enfoque tradicional, que considera a decisão um ato isolado e individual; b) o enfoque behaviorista, que leva em conta o ambiente e considera a decisão um ato coletivo e mais racional.

Em um problema de decisão, as pessoas selecionam uma alternativa de ação com a intenção de conseguir resultados ao menos tão satisfatório quanto aquele que teria com qualquer outra opção disponível. Quando esse objetivo é alcançado, diz-se que a decisão foi um sucesso; de outra forma, será um fracasso (Yates \& Stone, 1994).

Para Baron (1994), a decisão é uma escolha de ação; do que fazer ou não fazer. Decisões são tomadas para se conseguir determinados objetivos e são baseadas em crenças sobre quais ações permitirão que se alcancem tais objetivos. As ações, crenças e objetivos pessoais podem ser o resultado de pensamento ou de outros mecanismos. Segundo o autor, existe uma estrutura de pensamento, chamada de pesquisa-inferência, como a base da tomada de decisão; o processo do pensamento tem início com uma dúvida ou questão que tenha alguma importância para a pessoa. Para remover essa dúvida, é desencadeada uma pesquisa que envolve as possibilidades de solução, evidências e objetivos. Após a pesquisa é realizada a inferência ou uso das evidências, onde cada alternativa será fortalecida ou enfraquecida. Este processo não ocorre em uma ordem fixa e é perfeitamente possível a sobreposição das etapas. A figura 2.10 ilustra o processo do pensamento conforme proposto por Baron (1994).

Figura 2.10 A estrutura pesquisa-inferência do pensamento

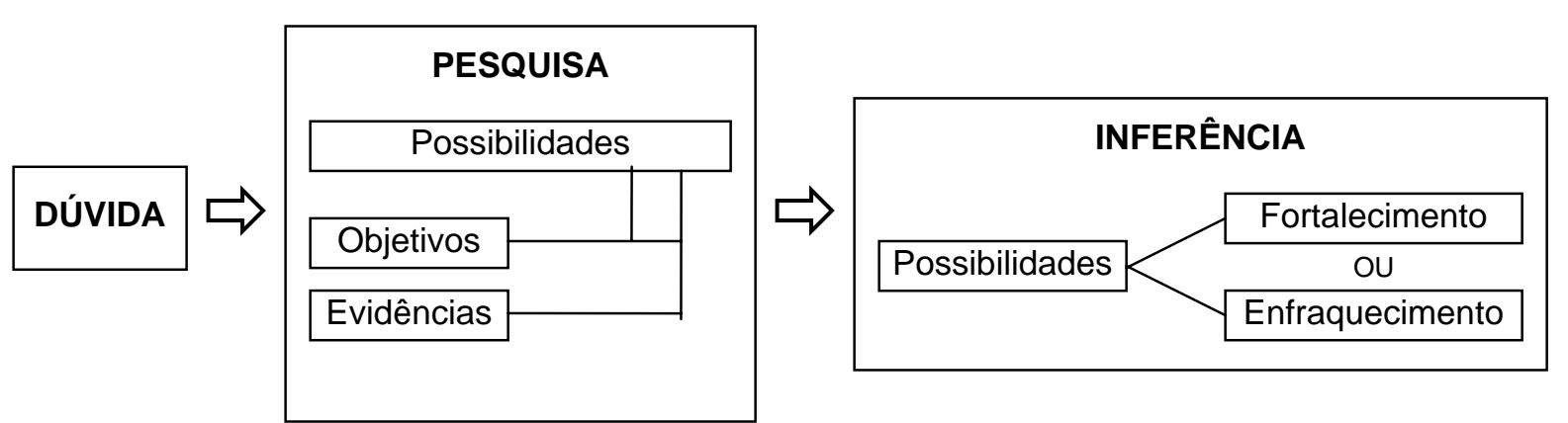


O processo de administração da inovação requer para o seu desenvolvimento que sejam tomadas inúmeras decisões envolvendo incertezas e riscos de diversas ordens. Essas decisões são fundamentais no processo de desenvolvimento da inovação, afetando o seu resultado final.

Entre as decisões tomadas pela alta administração de uma organização, Matheson \& Matheson (1998) apontam as decisões estratégicas da área de P\&D como sendo das mais difíceis devido ao grau de incerteza que as cercam. Os autores identificam quatro fatores que colaboram para torná-las tão difíceis:

- O tempo decorrido entre a tomada da decisão em inovar e o início da entrada de dinheiro em caixa, como fruto da inovação, é tipicamente longo e repleto de situações desconhecidas;

- O processo de P\&D é inerentemente incerto; nenhuma pessoa pode saber se dará certo e caso isso ocorra, quando será;

- Os mercados a serem atendidos são mais incertos na ocasião que o projeto de P\&D estiver sendo introduzido;

- O sucesso em P\&D, em geral, leva as empresas para áreas não familiares que requerem parceiros, alianças ou aquisições, e novas maneiras de fazer negócio.

Slack et al. (1997), observam que a incerteza é maior no início do projeto e vai decrescendo à medida que se avança para o seu final. Em contrapartida, a flexibilidade das decisões age no sentido contrário, isto é, a dificuldade e o custo para se alterar o projeto são pequenas no início e crescem quando se caminha para o seu final. Neste sentido, Clark \& Wheelwright (1993) constataram que muitos gerentes agem de forma incoerente, dedicando mais atenção ao projeto nas fases finais do seu desenvolvimento, quando a pressão para se solucionar os problemas se torna maior. É comum neste tipo de comportamento, que os autores chamam de reativo, a mobilização de uma grande quantidade de recursos na fase final do projeto, quando os problemas se tornam visíveis. Agindo dessa forma, desperdiçam a oportunidade de resolver boa parte dos problemas durante as fases iniciais e acrescentar vantagens competitivas ao novo produto.

Segundo Matheson \& Matheson (1998), as decisões, para efeito de análise da sua qualidade, podem ser divididas em dois grupos: decisões operacionais e decisões estratégicas. O motivo maior para tal distinção é que os ciclos de cada tipo de decisão são diferentes e conseqüentemente diversas características também se tornam diferentes. Como ciclo da decisão entende-se o período de tempo entre a tomada da decisão e a obtenção do resultado proveniente desta decisão. Os ciclos das decisões operacionais são tipicamente curtos; normalmente medidos em meses, dias, horas ou até 
minutos. Ao contrário, as decisões estratégicas possuem ciclos extremamente longos, algumas podem levar vários anos para completar o ciclo.

A decisão estratégica é pouco freqüente e, em geral, é única, dificultando o aprendizado e a melhoria baseados em evidência estatística (Arnold \& Keelin, 1994).

As principais características da decisão operacional e estratégica, conforme proposto por Matheson \& Matheson (1998), foram resumidas no quadro 2.7.

\section{Quadro 2.7 Distinção entre decisão operacional e estratégica}

\begin{tabular}{|c|c|}
\hline DECISÃO OPERACIONAL & DECISÃO ESTRATÉGICA \\
\hline $\begin{array}{l}\text { - Os erros não são tão caros. } \\
\text { - Envolve relativamente poucos recursos. } \\
\text { - Resposta do resultado em pouco tempo. } \\
\text { - É possível e recomendável aprender com } \\
\text { os resultados. } \\
\text { - Como o ciclo é curto, o desempenho ótimo pode ser } \\
\text { conseguido através de melhorias incrementais. } \\
\text { - A fonte de conhecimento é o próprio pessoal } \\
\text { envolvido na atividade. } \\
\text { Hábitos importantes } \\
\text { - Atentar aos detalhes e acompanhar o processo. } \\
\text { - Monitorar o desempenho de curto prazo. } \\
\text { - Ignorar as incertezas. } \\
\text { - Evitar alternativas. }\end{array}$ & $\begin{array}{l}\text { - Os erros são custosos. } \\
\text { - Envolve muitos recursos. } \\
\text { - Resposta do resultado extremamente longa. } \\
\text { - Esperar os resultados para aprender é } \\
\text { impraticável. } \\
\text { - Quando os resultados começam a surgir já é muito tarde } \\
\text { para mudar a estratégia. (ciclo longo) } \\
\text { - As fontes de conhecimento, em geral, são } \\
\text { especializadas e externas: especialistas e pesquisas. } \\
\text { - Cocompetências } \\
\text { - Considerar horizontes de longo prazo. } \\
\text { - Representar a incerteza } \\
\text { - Gerar várias alternativas e realizar uma escolha } \\
\text { cuidadosa. }\end{array}$ \\
\hline
\end{tabular}

Segundo Turban \& Meredith (1994), as situações de decisão podem ser classificadas de acordo com o grau de conhecimento que o decisor tem sobre a situação, sendo usual a divisão em três categorias:

1) Decisão tomada sob certeza - neste tipo de decisão é assumido que o decisor dispõe de informações completas, de tal forma que ele conheça exatamente o resultado de cada alternativa de ação que seja adotada. Este tipo de decisão também é chamado de decisão determinística.

2) Decisão tomada sob risco - também conhecida como decisão probabilística ou estocástica, é aquela na qual pode haver dois ou mais resultados possíveis para cada alternativa de ação devido à impossibilidade de controle dos estados da 
natureza por parte do decisor. Se for assumido que o decisor conhece ou pode estimar a probabilidade de ocorrência dos estados da natureza, então é dito que a decisão é tomada sob risco.

3) Decisão tomada sob incerteza - quando o decisor, assim como na decisão sob risco, se defronta com mais de um resultado possível para cada ação e além disso não conhece, nem pode estimar, a probabilidade de ocorrência dos estados da natureza, diz-se que decide sob incerteza. Entretanto, é assumido que o decisor conhece os possíveis estados da natureza.

A figura 2.11 ilustra os três tipos de decisões citados.

Figura 2.11 As categorias de tomada de decisão

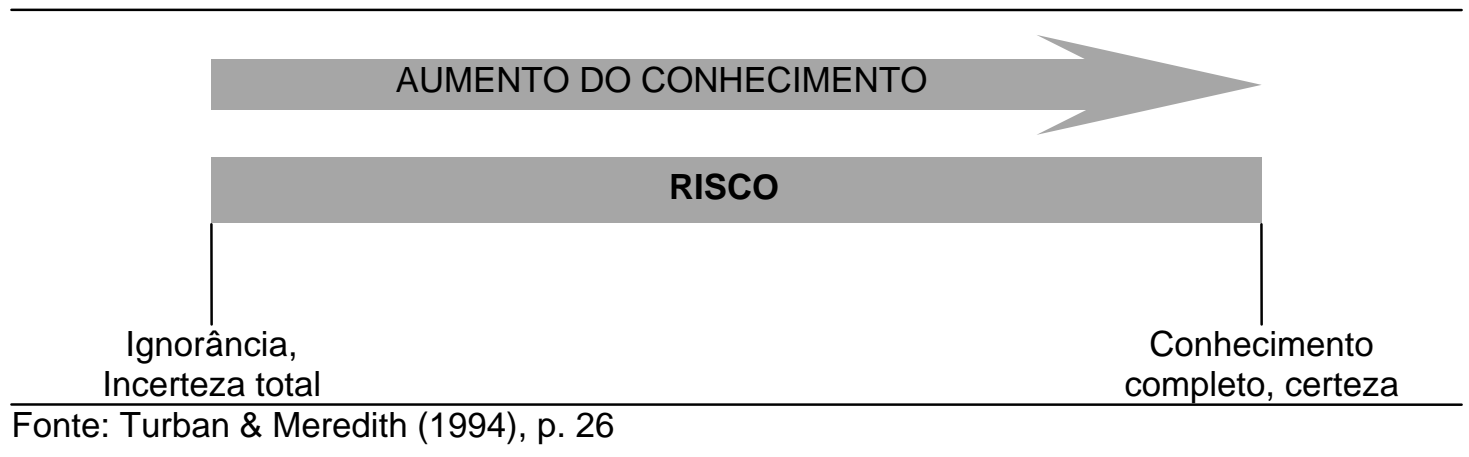

\subsubsection{O risco e a incerteza na decisão}

A tomada de decisão, a incerteza e o risco são conceitos que têm sido abordados por diversos pesquisadores das mais diversas áreas, tais como economia, administração, psicologia, filosofia, sociologia e outras, com um caráter descritivo ou prescritivo (Miller \& Starr, 1970).

Para Moore (1997), o risco trata de acontecimentos futuros e está presente na vida de todos em diversas ocasiões; sem assumir riscos é impossível um progresso econômico e até mesmo a manutenção do status quo.

Hardy (1923), citado por Strassmann (1959), apresenta a seguinte caracterização do risco: 
Em um certo sentido, todos os riscos são devidos à ignorância. Se todas as condições de qualquer situação fosse conhecida não haveria risco envolvido nela para ninguém. Existe, entretanto, uma distinção importante entre riscos devidos às limitações do conhecimento humano e os riscos que são devidos à falha ou inabilidade dos indivíduos em aproveitar o conhecimento que é acessível para ele (Hardy, 1923, p.2 citado por Strassmann, 1959, p. 16).

O conceito moderno de risco, segundo Bernstein (1996), tem sua origem no sistema de numeração hindu-arábico, que chegou ao ocidente por volta do ano 1200, mas somente em 1654, através das leis da probabilidade desenvolvidas por Pascal e Fermat é que o estudo do risco assume a forma conhecida atualmente e tratada pela teoria da decisão.

Segundo Yates \& Stone (1994), o risco é inerentemente subjetivo, variando de um indivíduo para outro. Este fato aliado às diferentes formas e situações que o risco pode se apresentar deixam uma impressão que existem diversos conceitos para o termo risco. Fischoff (1985), citado por Yates \& Stone (1994), observa que as pessoas, em geral, discordam mais sobre o que é risco do que o quão grande ele é.

Para Yates \& Stone (1994) é concebível que as pessoas utilizem o termo risco de diferentes formas, uma vez que estejam se referindo a entidades que não têm conexão uma com a outra, mas consideram essas diferenças como sendo mais aparentes do que reais. Segundo os autores, é possível estabelecer um constructo que está em torno das diversas concepções, aparentemente diferentes, de risco.

Segundo Moore (1997), existem dois componentes básicos do risco: primeiro, um resultado futuro que pode tomar diferentes formas, algumas delas comumente desfavoráveis; em segundo lugar, uma possibilidade diferente de zero de que o resultado menos favorável pode ocorrer.

Para Yates \& Stone (1994), o risco é intrinsecamente repugnante. O argumento apresentado para essa afirmativa é que na situação de assumir risco existem, além do risco, outros aspectos que devem ser considerados. Assim, do ponto de vista do decisor, o valor de uma alternativa é função do risco e de "outras considerações", onde a possibilidade de uma alternativa ser escolhida aumenta com o seu valor. Essa idéia pode ser expressa como: Valor $=f($ risco, outras considerações).

Moore (1997) compartilha dessa idéia de que existem "outras considerações", além da possibilidade de perda.

As palavras risco e perigo são capazes de expressar duas idéias: primeiro, um perigo localizado em algum aspecto do mundo externo e segundo, a idéia de ação em um caminho que envolve a possibilidade. Mas Shakespeare nos lembra que risco não está conectado apenas com a possibilidade de perda ou prejuízo, mas também com a esperança de algum benefício ou ganho (Moore, 1997 p.3). 
Quando, aparentemente, alguém escolhe uma alternativa de maior risco, a razão não é a falta de repugnância ao risco e sim, o fato de que as "outras considerações" devem incluir benefícios atrativos. Em outras palavras, a razão de uma alternativa que contenha risco não ser rejeitada logo no início é que as outras considerações introduzem benefícios atrativos, assim como podem incluir aspectos negativos adicionais.

A afirmação de que o risco é intrinsecamente repugnante, vai contra a idéia de neutralidade e propensão ao risco admitida na teoria da decisão ${ }^{2}$. Neste sentido, Yates \& Stone (1994), criticam a forma que a teoria da decisão utiliza para avaliar o perfil de comportamento das pessoas quanto ao risco, argumentando que a preferência ou neutralidade de uma pessoa por uma alternativa de maior risco é, obrigatoriamente, acompanhada de outras considerações atraentes. Para os autores, o método utilizado pela teoria da decisão para caracterização do perfil de comportamento face ao risco é limitado, uma vez que não considera o benefício de outros fatores.

Segundo Bernstein (1996), foi o matemático francês Abraham de Moivre quem talvez definiu, pela primeira vez, explicitamente, o risco como chance de perda. Essa definição surgiu no livro "De mensura sortis" publicado em 1711, na seguinte forma: "O risco de perder qualquer soma é o inverso da expectativa; e sua verdadeira medida é o produto da soma arriscada pela probabilidade de perda" (Bernstein, 1996, p. 125).

\subsubsection{O constructo de risco}

Yates \& Stone (1994) reconhecem a existência de diversas medidas e definições operacionais para risco, normalmente, com enfoque em apenas um dos elementos que o compõe e consideram a definição de risco como uma possibilidade de perda, a mais geral. Mas esta definição não deixa claro como se relacionam a possibilidade e a perda, isto é, não explicita quais são os elementos de risco. Segundo os autores, estritamente falando, o risco não é um aspecto da alternativa de decisão por si mesmo. De fato, ele representa uma interação entre a alternativa e o agente que assume o risco; em outras palavras, o risco é um constructo inerentemente subjetivo. Isso, porque aquilo que é considerado uma perda é uma preocupação peculiar de cada pessoa, bem como a significância dessa perda e sua possibilidade de ocorrência.

\footnotetext{
${ }^{2}$ A idéia de neutralidade e propensão ao risco da teoria da decisão é abordado no item 2.5.3.1.
} 
O constructo de risco proposto por Yates \& Stone (1994) é composto de três elementos críticos: 1) perdas potenciais; 2) a significância das perdas; 3) a incerteza das perdas.

\section{1) Perdas potenciais}

Uma perda ocorre, quando alguém está privado de um resultado que já possuía ou que poderia conseguir; e mais, este alguém ficou com o resultado que é menos interessante do que aquele que foi deixado de lado ou impedido de ser alcançado. Logo, segundo Kahneman \& Tversky (1979), citado por Yates \& Stone (1994), fica implícito no conceito de perda a noção de um resultado de referência. Qualquer resultado que é preferido em relação à referência é um ganho, ao passo que se for menos preferido será uma perda.

Desta forma, a perda depende do referencial que o tomador de decisão escolhe e pode ser baseado no status quo ou não. Esse referencial pode ser escolhido de acordo com diversos critérios, tais como: média pessoal, referente a uma situação, expectativa social, alvo, arrependimento e outros.

Para Maccrimmon \& Wehrung (1986), existem duas formas principais de perda potencial que devem ser consideradas: 1) um resultado que tornará o indivíduo pior do que uma posição referente ao status quo; 2) um resultado que não é tão bom quanto algum outro resultado que poderia ter sido obtido.

A primeira forma é facilmente percebida como uma perda, mas a segunda, chamada de perda de oportunidade, pode não ser tão evidente. Segundo os autores, a perda de oportunidade pode, algumas vezes, transformar uma situação aparentemente isenta de risco em uma nova situação com risco, caso ocorram eventos desconhecidos.

Neste sentido, Moore (1997), afirma que quando termos como "alto risco" ou "baixo risco" são usados, o significado normalmente depende do elemento que serviu de base inicial e das conseqüências que a ocorrência do risco pode ter para esse elemento. Uma forma simples de representar o nível de perda é admitindo-o como sendo expresso em múltiplos do elemento referencial.

A figura 2.12 ilustra esquematicamente as combinações de probabilidades de perda contra níveis de perda que definem a chamada situação de alto risco e a dualidade implicada pelo uso do termo risco em duas dimensões. As curvas limites são indicativas dos tipos de situações rotuladas com os vários graus de risco. 
Figura 2.12 Níveis de risco

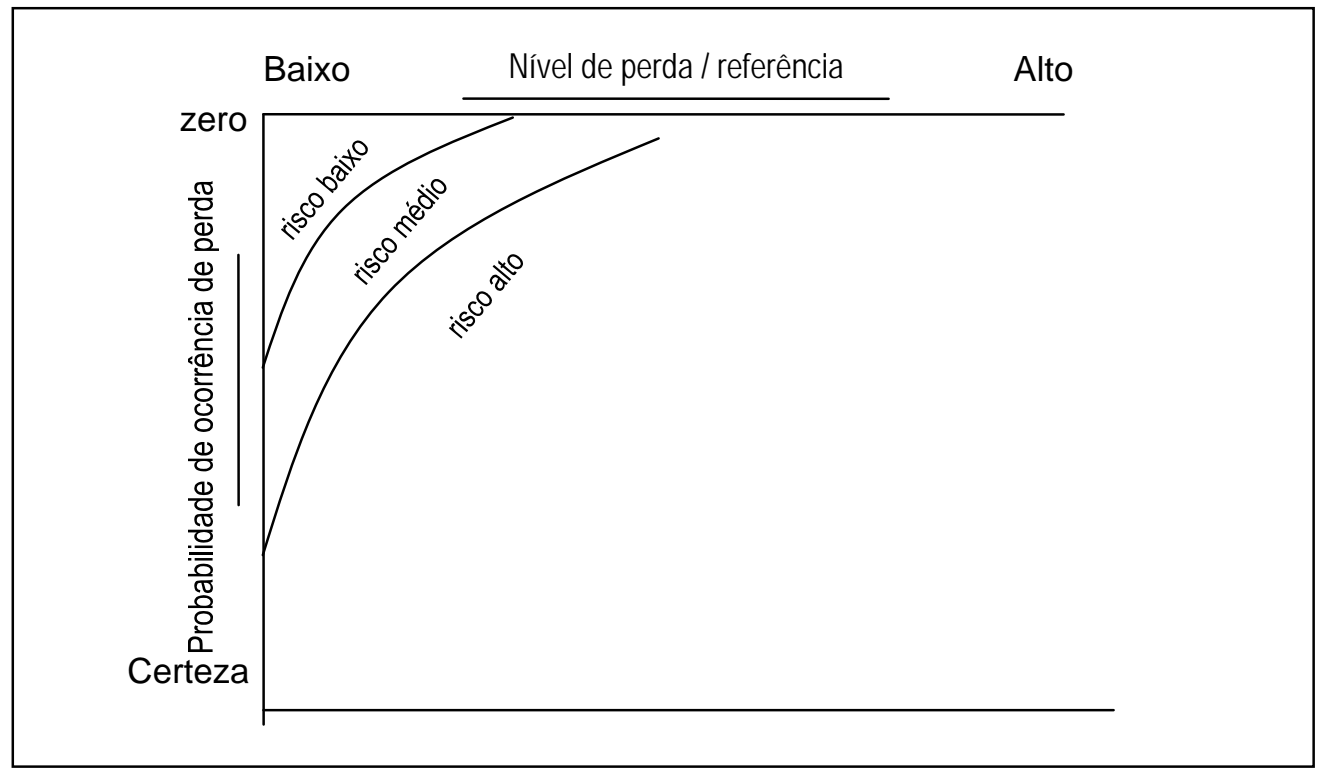

Fonte: Moore, 1997, p.2

Segundo Yates \& Stone (1994), diversas áreas da pesquisa do risco reconhecem a existência de uma multiplicidade de categorias de resultados e suas conseqüentes classes de perdas que são possíveis em situações de se assumir risco. A taxionomia de risco desenvolvida por Jacoby \& Kaplan (1972), citado por Yates \& Stone (1994), na área de comportamento do consumidor, é uma das que são mais freqüentemente mencionadas. De acordo com esse sistema, as perdas que uma compra pode produzir são das seguintes categorias: financeira, de desempenho, psicológica, física, social e de tempo.

\section{2) Significância das perdas}

Segundo Yates \& Stone (1994), os pesquisadores assumem que quanto mais significante a perda potencial, maior é o risco. A significância da perda pode ser distinta de pessoa para pessoa. Em se tratando de perda monetária para pessoas que preferem ter mais dinheiro do que menos, pode-se ter três diferentes função valor, conforme ilustrado na figura 2.13. 


\section{Figura 2.13 Alternativas da função valor para perdas}

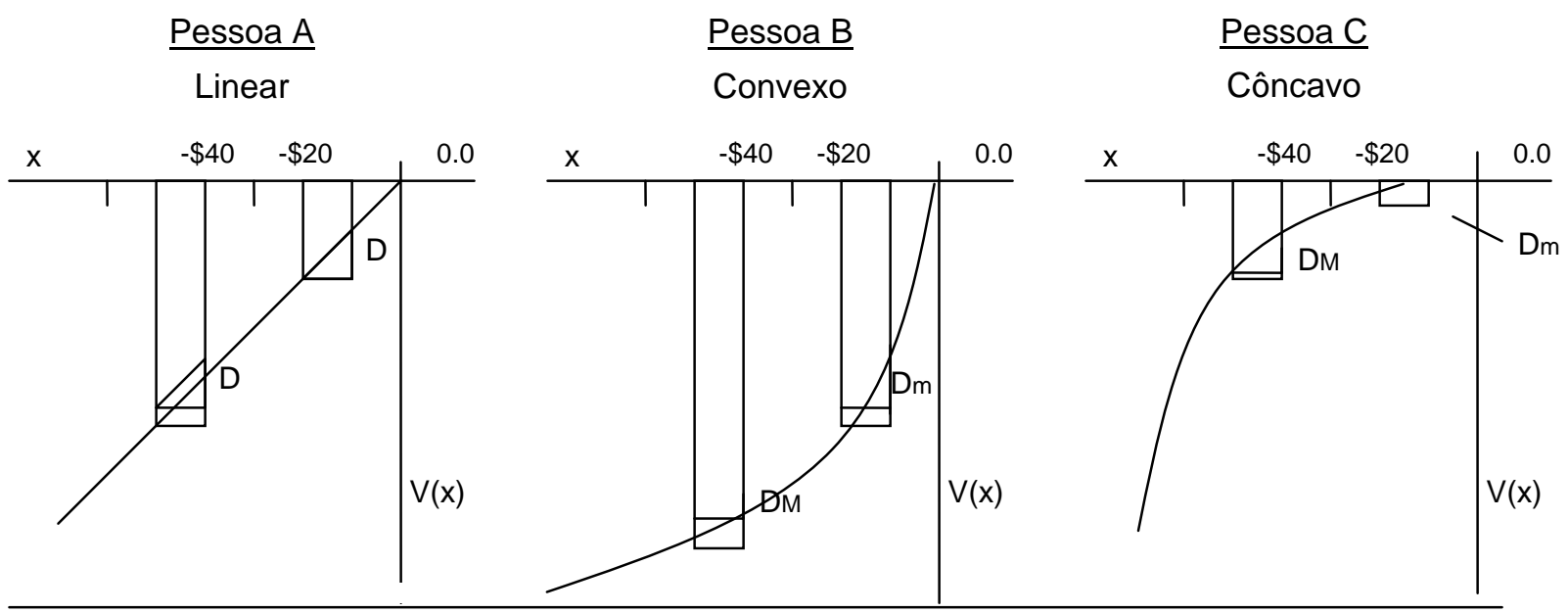

Fonte: Yates \& Stone, 1994, p.10

$\mathrm{Na}$ figura 2.13, a função valor linear da pessoa $\mathrm{A}$ indica que o grau de mudança na significância de perda monetária é constante. De fato, uma perda adicional de \$10 reduz a satisfação da pessoa $A$, sempre da mesma quantidade, denominada $D$. A função valor convexa da pessoa B indica uma diminuição da significância marginal, à medida que a magnitude da perda aumenta. Isso implica, como sugerido na figura, que a perda adicional de \$10 tem menos importância para a pessoa $B$ quando ela já tiver perdido quantidades maiores do que quando perdeu quantidades menores, DM versus Dm. A função valor côncava da pessoa C descreve o caminho oposto de respostas das perdas.

Essas diferentes funções valor para perdas implicam em correspondentes diferenças na forma que as pessoas $A, B$ e $C$ avaliariam o risco de alternativas que pudessem resultar em perdas financeiras.

\section{3) Incerteza das perdas}

Segundo Yates \& Stone (1994), na concepção de risco está implícito a existência de incerteza sobre o resultado de ações prospectivas; caso contrário, se os resultados são garantidos, não existe risco. Para os autores, existem pelo menos quatro aspectos distintos da incerteza que são comumente discutidos: a) o risco como incerteza; b) incerteza sobre as categorias de perda; c) incerteza sobre qual perda ocorrerá; d) níveis de incerteza. 


\section{a) O risco como incerteza}

Algumas vezes se diz que existe risco se os resultados de uma ação não são certos ou garantidos. Neste caso, o risco é efetivamente incerteza. Isso ocorre, por exemplo, quando um economista se refere a qualquer perspectiva com retorno não garantido como risco. "O termo risco é usado alternativamente com incerteza, ao referir-se à variabilidade de retornos associada a um dado ativo" (Gitman, 1997, p. 202).

$\mathrm{Na}$ análise de decisão, a concepção de risco, implícita em várias discussões sobre o comportamento de quem assume risco, também é a de risco como incerteza. Os conceitos de "valor esperado" e "equivalente certo" empregados na análise de decisão para determinar a tolerância ao risco do decisor não consideram a atratividade que pode existir na alternativa de maior risco.

\section{b) Incerteza sobre as categorias de perda}

Tomando-se como exemplo a situação onde uma pessoa deve decidir se aceita ou não a proposta de um novo emprego é possível imaginar que existem diversas categorias de perdas potenciais. A localização, o ambiente, o salário e o crescimento profissional são categorias de perda potenciais, mas muito provavelmente existem outras tantas. As situações diferem na extensão das categorias de resultados potenciais e conseqüentemente nas possíveis perdas. $O$ risco destas situações aumenta com a incerteza sobre quais as categorias de perda que realmente estão presentes.

\section{c) Incerteza sobre qual perda ocorrerá}

Ainda que seja reconhecido que perdas de uma certa categoria podem ocorrer, existe a dúvida se esta perda irá ocorrer. Quanto maior a chance de uma perda ocorrer, maior é o risco.

Possibilidade de perda é a forma padrão de caracterização do risco em medicina e epidemiologia, por exemplo, com índices de mortalidade por doença.

\section{d) Níveis de incerteza}

O nível de incerteza tem importância para a caracterização do risco e está relacionado com a firmeza da base na qual as possibilidades de perdas são designadas. Os pesquisadores de decisão estabeleceram um contínuo de níveis de incerteza, onde o ponto extremo em que não existe base alguma para fixar as possibilidades de perda foi chamado por Luce \& Raiffa (1957), citado por Yates \& 
Stone (1994), de "ignorância". Quando as possibilidades do resultado são bem estabelecidas pelo consenso (como por exemplo a possibilidade do resultado do lançamento de uma moeda) tem-se o ponto chamado "objetividade", também descrito como probabilidade objetiva ou probabilidade aleatória. Entre os pontos ignorância e objetividade estão vários estados descritos como ambigüidade por Ellsberg (1961), citado por Yates \& Stone (1994).

A figura 2.14 ilustra o contínuo do nível de incerteza.

\section{Figura 2.14 Níveis de incerteza}

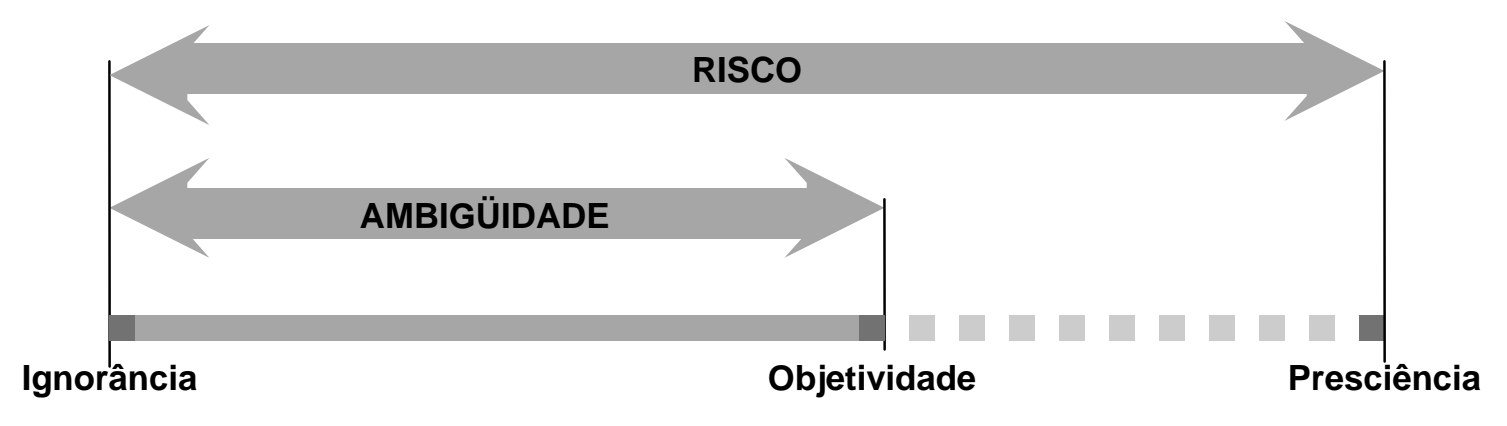

Fonte: modificado de Yates \& Stone, 1994, p. 14

Segundo March \& Shapira (1987), citado por Yates \& Stone (1994), as pesquisas indicam que os executivos fazem uma distinção profunda entre assumir risco e jogar. Estes executivos argumentam que embora assumir risco seja uma parte essencial de suas responsabilidades, jogar é alguma coisa que eles evitam. Esta concepção dos executivos sobre a situação de jogo parece envolver duas questões: primeiro, nos jogos as probabilidades de perda são inaceitáveis, de tão grandes; em segundo lugar, além de um certo ponto é impossível aprender alguma coisa para reduzir a incerteza em um jogo. Assim, uma grande parte do tratamento dispensado pelos executivos em relação ao risco envolve a descoberta do resultado que ocorrerá caso seja tomada uma determinada ação. Se a situação não permite este tipo de descoberta, o executivo a evitará se assim for possível. Aparentemente, com esse comportamento, o executivo está buscando ultrapassar o ponto de objetividade no contínuo de incerteza e se aproximar da presciência.

Segundo Yates \& Stone (1994), em diversas situações práticas e de pesquisa, é comum os especialistas em risco indexar o risco com apenas um dos elementos. Isso não significa que esses especialistas acreditem que tal medida consiga capturar o constructo de 
risco; na maior parte das vezes, o mesmo se deve aos propósitos limitados da situação, onde esse tipo de medida é suficiente.

Para analisar como seria possível combinar os vários elementos de risco para se determinar o risco total, Yates \& Stone (1994), consideram duas idéias básicas na combinação de princípios: a) interação e b) independência.

\section{a) Interação}

A interação refere-se à forma como a significância e a incerteza, associadas com uma dada perda, juntas, afetam o risco total. Supondo-se que:

- A incerteza associada com uma perda específica (Perda i) seja representada pela sua probabilidade $\mathbf{P}$ (Perda i);

- A significância dessa perda possa ser caracterizada pelo índice de importância I (Perda i).

A primeira noção de combinação do risco é capturada pela seguinte equação conceitual: Risco i = P (Perda i) $\otimes \mathbf{I}($ Perda i $)$.

A probabilidade e a significância estão combinadas por um operador $(\otimes)$ que se comporta essencialmente, mas não completamente, como multiplicação. Os especialistas em risco, algumas vezes, relutam em aceitar totalmente o operador multiplicação, porque em alguns casos a intuição contradiz tal operador sobre o comportamento do risco. Por exemplo, Kaplan \& Garrick (1981), citado por Yates \& Stone (1994), argumentam que é difícil equacionar o risco de um cenário com alto prejuízo e baixa probabilidade, assim como o cenário de baixo prejuízo e alta probabilidade. 


\section{b) Independência}

A segunda idéia que recorre na combinação dos princípios de risco é aplicada em situações nas quais mais de uma perda pode ocorrer, ou seja, os efeitos dessas perdas são independentemente acumulativos.

Em contraste à combinação interativa da significância e incerteza, a contribuição ao risco total de uma perda potencial é sempre a mesma, independente da outra perda potencial que acompanha. Supondo-se que:

- O risco envolvendo a perda potencial (Perda 1) seja expresso por Risco(Perda 1);

- O risco envolvendo a perda potencial (Perda 2) seja expresso por Risco(Perda 2) e assim por diante.

A segunda noção de combinação do risco é capturada pela seguinte equação conceitual: Risco total $=\operatorname{Risco}($ Perda 1) $\oplus$ Risco $($ Perda 2) $\oplus \ldots$

Nesta equação o operador $(\oplus)$ é equivalente à adição.

Desta forma, o risco total resultante de uma coleção de perdas potenciais é uma acumulação das contribuições feitas por cada uma delas.

Segundo Yates \& Stone (1994), as idéias de interação e independência têm sido operacionais na pesquisa e administração através das seguintes representações do risco total:

\section{1) Perda esperada}

A perda esperada é a caracterização do risco total que captura os dois princípios mais diretamente. Considerando-se que:

- L seja a perda advinda de um dado resultado X e referência $R f$, então:

$L=R f-X$

- $\mathrm{P}(\mathrm{L})$ seja a probabilidade desta perda

- A perda esperada (PE) é a soma de todas as perdas potenciais ponderadas com suas probabilidades: $P E=\Sigma P(L) L$, onde a somatória é tomada sobre todos os resultados considerados piores que a referência.

- Uma variante da perda esperada aplicada a resultados não quantificados toma a seguinte forma: $P E=\Sigma P(L) I R(L)$, onde $I R(L)$ é um índice de importância relacionado à perda $L$, representado pelo resultado $X$. A somatória é tomada sobre todos os resultados considerados piores que a referência.

\section{2) Variância}


A variância é uma medida da dispersão dos resultados em relação à média ou valor esperado, utilizada para medir o risco, principalmente em finanças. Ross \& Westerfield \& Jaffe (1995), por exemplo, ressaltam que não existe uma definição universalmente aceita de risco, mas que uma das formas de se pensar no risco dos retornos de ações é através do grau de dispersão.

Considerando que:

- O valor esperado (VE) ou média de qualquer distribuição é a soma de todos os valores possíveis $(X)$, cada um ponderado pela sua probabilidade, então:

- A variância (Var) será: $\operatorname{Var}=\Sigma P(X)(X-V E)^{2}$, onde a somatória é tomada sobre todos os resultados $X$, e não apenas sobre as perdas.

A variância é vista algumas vezes como uma medida imperfeita do risco, porque é afetada não somente pelas perdas, mas pelos ganhos também. Nesse caso, duas alternativas cujas distribuições de resultados são idênticas em relação às perdas podem entretanto ser consideradas diferentes quanto à quantidade de risco.

\section{2) Semivariância}

Pode ser uma medida do risco total quando se acredita que o risco associado a uma perda quantificada aumenta de forma dramática com a magnitude da perda. Considerando a notação utilizada anteriormente:

- SemiVar $=\Sigma \mathrm{P}(\mathrm{L}) \mathrm{L}^{2}$

\section{4) Risco total quando existem múltiplas categorias de resultados}

As três caracterizações do risco total apresentadas pressupõem que existe apenas uma categoria de resultado, mas é consideravelmente freqüente as situações com mais de uma categoria.

Essa questão tem sido tratada em comportamento do consumidor, onde a abordagem sugerida é uma extensão direta do princípio de acumulação independente. Dessa forma, a perda esperada (PE) será:

- $\mathrm{PE}=\Sigma \Sigma \mathrm{P}(\mathrm{L}) \operatorname{IR}(\mathrm{L})$, onde a segunda somatória se estende sobre todas as categorias de resultados pertinentes. 


\subsubsection{O paradigma do risco básico}

O conceito de risco apresentado por Maccrimmon \& Wehrung (1986) tem alguns pontos em comum com o constructo de risco de Yates \& Stone (1994), mas por outro lado, existem algumas divergências. Do ponto de vista do risco presente nas decisões que envolvem inovações, aparentemente, o conceito apresentado por Maccrimmon \& Wehrung é mais pertinente.

Maccrimmon \& Wehrung (1986) consideram a situação que um certo indivíduo enfrenta para se decidir sobre um determinado assunto como um modelo de análise de risco e a esse modelo chamam de paradigma do risco básico. Para exemplificar, os autores consideram a seguinte situação:

Quando a pesquisa e desenvolvimento oferece a possibilidade de melhorar um produto existente, um gerente deve decidir se deixa o produto como está ou se faz as melhorias. Se o gerente fica com o produto inalterado, os lucros permanecerão no seu nível atual. Supondo-se, por exemplo, que o lucro gerado por esse produto seja de $\$ 20$ milhões. Se o produto for modificado o lucro passará a depender da aceitação do novo produto pelos consumidores. Suponha que uma pesquisa de mercado indicou que existe $75 \%$ de chance de uma forte aceitação, resultando em um aumento de \$4 milhões no lucro mas, existe $25 \%$ de possibilidade que a aceitação seja fraca e neste caso haverá uma queda no lucro de $\$ 12$ milhões. O gerente deve ir em frente (p.11)?

O exemplo citado, para os autores, ilustra os elementos básicos que existem em situações de risco. Existem duas possíveis ações: uma ação, chamada ação segura, é a manutenção do status quo, enquanto a outra ação, chamada de ação de risco, tem dois resultados possíveis, um ganho e uma perda. O problema é que não se conhece com certeza qual desses dois resultados ocorrerá. O resultado depende de um evento incerto para o qual se tem somente conhecimento probabilístico. Esta situação pode ser representada pelo esquema (árvore de decisão) da figura 2.15.

\section{Figura 2.15 A decisão de modificar o produto}

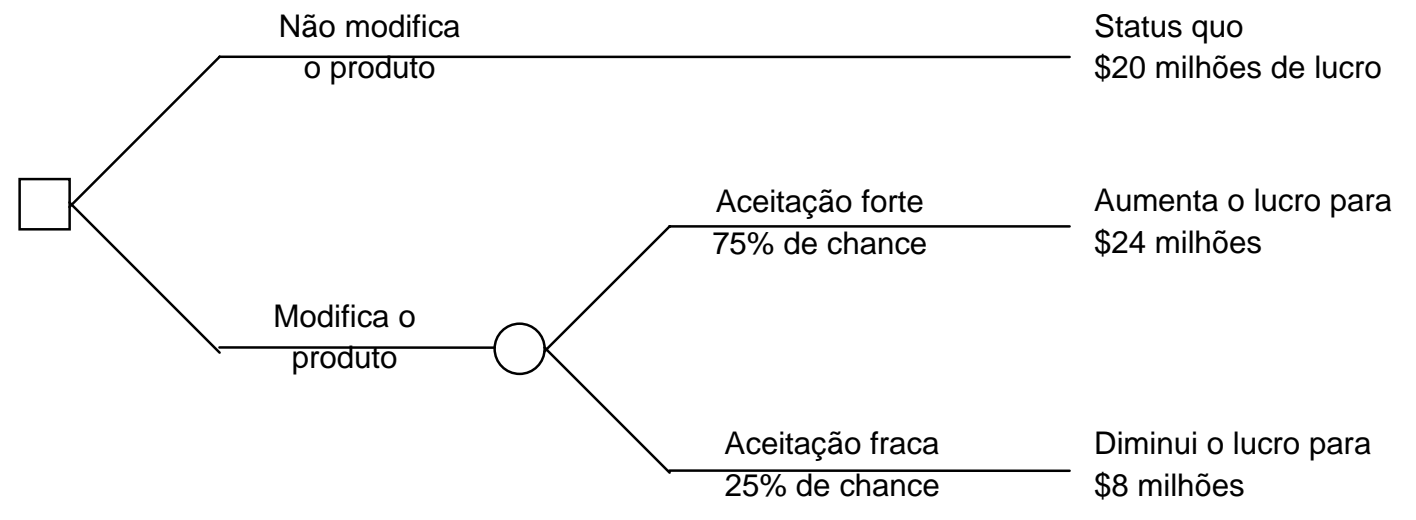

Fonte: Maccrimmon \& Wehrung, 1986, p. 12 
O paradigma do risco básico pode ser representado pela figura 2.16 , que é essencialmente igual à figura 2.15, apenas substituindo-se a nomenclatura utilizada no exemplo por uma genérica.

\section{Figura 2.16 O paradigma do risco básico}

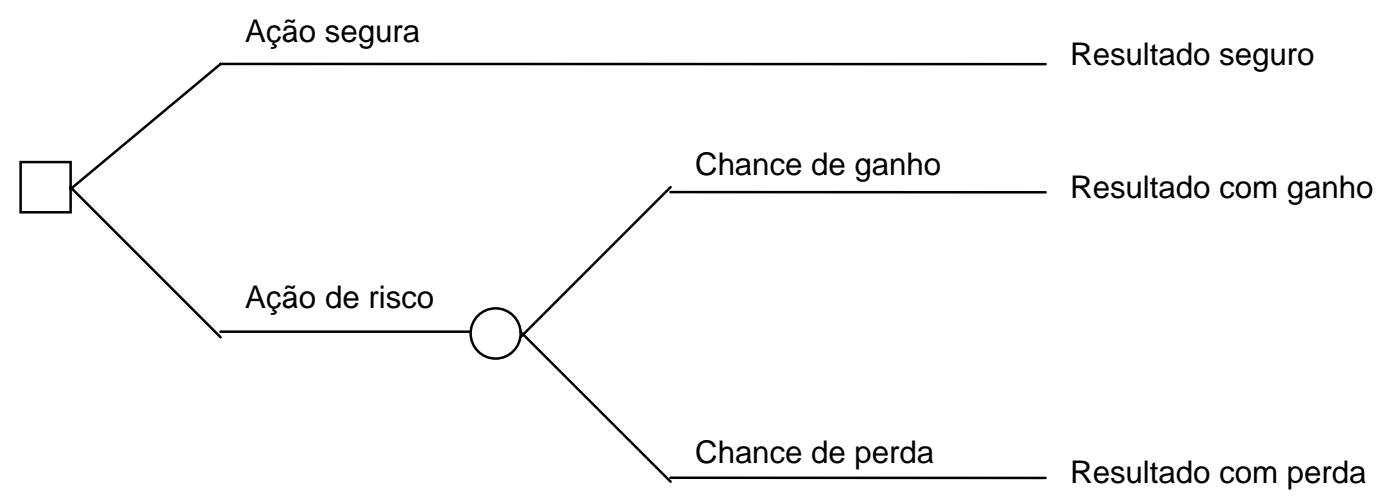

Fonte: Maccrimmon \& Wehrung, 1986, p. 12

O paradigma do risco básico, como o próprio nome sugere, é uma representação da situação de risco na sua forma mais simples. Evidentemente, nos casos reais de risco, o modelo de árvore da decisão precisa ser mais elaborado para expressar essa realidade, contudo, isso não invalida o modelo básico. Assim, é perfeitamente admissível as seguintes elaborações sobre o paradigma do risco básico:

1) A ação segura não necessariamente tem de ser o status quo. Ela pode ser qualquer ação com um resultado seguro, entre os resultados de ganho e perda da ação de risco;

2) Ambas as ações podem ser de risco, embora uma delas deva ser de maior risco que a outra;

3) Pode haver mais do que duas ações;

4) As ações de risco podem ter mais que dois possíveis resultados.

O risco, segundo, Maccrimmon \& Wehrung (1986), possui três elementos fundamentais: a magnitude da perda, a chance de perda e a exposição à perda. Para se alterar o risco, aumentando ou diminuindo, é necessário alterar pelo menos um desses elementos.

A exposição ao risco pode ser considerada em relação a três entidades distintas: a) o indivíduo que toma a decisão; b) a unidade social próxima do indivíduo que toma a decisão (em geral, a família ou a empresa); c) a sociedade como um todo. No exemplo da modificação do produto, a perda para o gerente pode atingir, por exemplo, a sua 
reputação ou até o seu emprego. Quanto à entidade empresa, a perda seria a queda do lucro e finalmente, para a sociedade poderia ser a indisponibilidade do modelo de produto preferido.

Em qualquer situação de risco, de acordo Maccrimmon \& Wehrung (1986), existem três fatores determinantes: a falta de controle, a falta de informação e a falta de tempo. Se existir completo controle da situação, será possível determinar o melhor resultado e não haverá risco. Se a informação sobre qual evento deve ocorrer for completa será possível escolher a alternativa do melhor resultado e também não haverá risco e por último, se não houver limitação do tempo para se decidir será possível esperar até a ocorrência do evento incerto e escolher a alternativa do melhor resultado. A relação entre controle, informação e tempo é ilustrada na figura 2.17.

Para se aumentar o controle sobre uma situação de risco é necessário informação e tempo, bem como recursos. A informação é necessária para se conhecer o impacto no resultado das várias opções de controle; para se obter as informações é necessário tempo e sem os recursos necessários para agir o controle não será efetuado.

Figura 2.17 Relação entre situação de risco e comportamento de risco

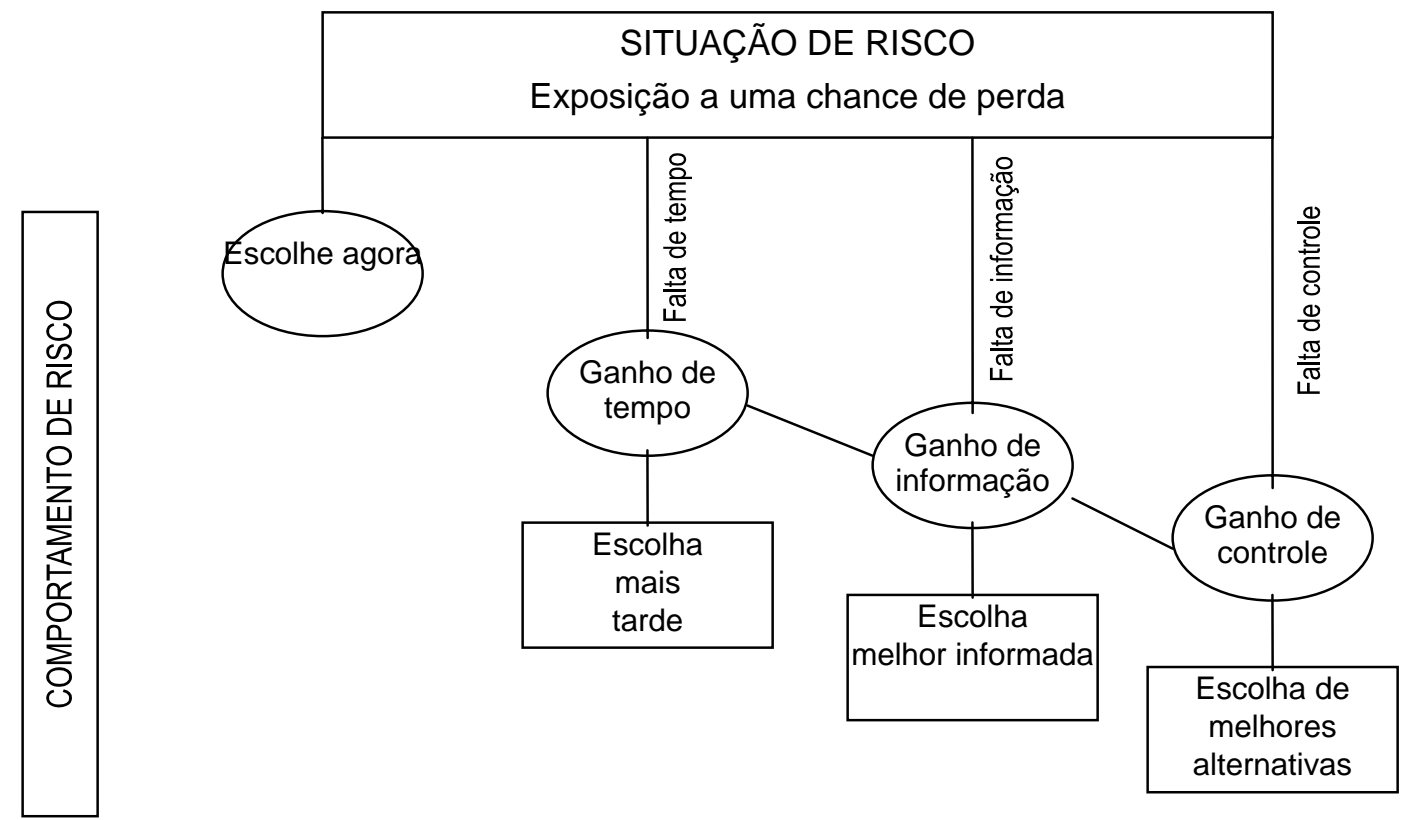

Fonte: Maccrimmon \& Wehrung, 1986, p. 17 


\subsubsection{A percepção do risco}

A percepção humana é uma questão que tem sido estudada pelos psicólogos há muitos anos ${ }^{3}$; durante este período, diversos experimentos e teorias foram elaboradas a respeito do assunto. Considerando-se o interesse despertado neste trabalho sobre a questão de como as pessoas que tomam decisões percebem o risco, foi incluído neste item, algumas das concepções e teorias sobre a percepção. Dada a complexidade do assunto e as restrições de escopo do trabalho, foi feito apenas um apanhado superficial, com o intuito de auxiliar na compreensão do que é a percepção humana, sem a pretensão de se esgotar o assunto.

A percepção, segundo Davidoff (1983), é definida como um processo que organiza e interpreta os dados sensoriais recebidos para o desenvolvimento da consciência do ambiente que nos cerca e de nós mesmos. De acordo com a Enciclopédia de Psicologia (1975), a percepção é uma função psicológica, que (através dos órgãos do sentido) permite ao organismo receber e processar informações sobre o estado do ambiente e as alterações ocorridas. Maximiano (1997), observa que a percepção funciona como "par de óculos psicológicos", isto é, um mecanismo que permite a interpretação dos estímulos ambientais.

Do ponto de vista fisiológico, segundo Davidoff (1983), a percepção depende de quatro operações: detecção, transdução, transmissão e processamento da informação. A detecção é desenvolvida pelos sistemas sensoriais; a visão, a audição, o paladar e o olfato são os mais conhecidos, mas segundo os cientistas, existem ao todo onze sentidos humanos bastante distintos. Os sentidos detectam, fazem a transdução, que é a transformação de um tipo de energia em outro e realizam a transmissão de informações sensoriais para os locais que serão processadas. O processamento da informação sensorial ocorre em diferentes locais dos sistemas sensoriais e nervoso.

\subsubsection{O processamento da informação}

Segundo Barber \& Legge (1976), os sinais do mundo externo que atingem o sistema sensorial é apenas uma parte das informações que chegam ao sistema nervoso central para ser processado. Outros sinais originários do interior do corpo, que transmitem informações sobre o seu funcionamento, também se encaminham para o sistema nervoso central. Esse grande conjunto de informações formado pelos sinais internos e externos ao organismo, precisam, de alguma forma, serem ordenados para que possa haver uma base de interação do indivíduo com o meio. O mecanismo que realiza esta complicada tarefa é chamado pelos psicólogos de atenção. Segundo Moray (1969),

\footnotetext{
${ }^{3}$ Segundo a Enciclopédia de Psicologia (1975), a psicologia de elementos do século XIX concebia a percepção como um processo responsável pela coordenação das sensações elementares em termos de imagens e idéias.
} 
citado por Barber \& Legge (1976), existem pelo menos sete conceitos distintos de atenção: a concentração mental, a vigilância, a atenção seletiva, o nível de ativação, a disposição ou prontidão e a análise por síntese.

Após vários experimentos, Broadbent (1958), citado por Barber \& Legge (1976), desenvolveu um modelo para explicar uma parte do processamento das informações, aquela que faz a seleção.

Este modelo, ilustrado na figura 2.18, é composto de dois sistemas básicos, a estocagem sensorial e a percepção, ligados por um filtro que controla o fluxo de informações entre eles. O fluxo de informações captado pelo sistema sensorial entra na estocagem e lá permanece durante algum tempo. Nesta estocagem, a informação permanece no seu estado bruto, isto é, não sofre qualquer tipo de tratamento. Após um certo tempo, ou esta informação é enviada para o sistema de percepção, passando através do filtro, ou é destruída e deixa de existir.

O filtro representa o sistema selecionador na atenção e sobre o seu funcionamento surgiram diversas teorias. Originalmente, este filtro foi concebido pelo autor do modelo como um comutador rotativo que seleciona os itens pela sua filiação a um canal. Este canal pode ser concebido como um atributo compartilhado por um conjunto de itens que podem ser selecionados pelo filtro. O filtro seleciona os canais de acordo com alguns critérios, como por exemplo, a intensidade física, a novidade, o estado de necessidade motivacional do organismo, os sons de alta freqüência em preferência aos de baixa, os estímulos sonoros de preferência aos visuais e outros.

O sistema percepção processa as informações filtradas e pode enviá-las para três destinos diferentes: a memória de longo prazo, de volta para o sistema de estocagem ou para processos de respostas.

Figura 2.180 modelo de processamento da informação de estimulações paralelas (segundo Broadbent, 1956)

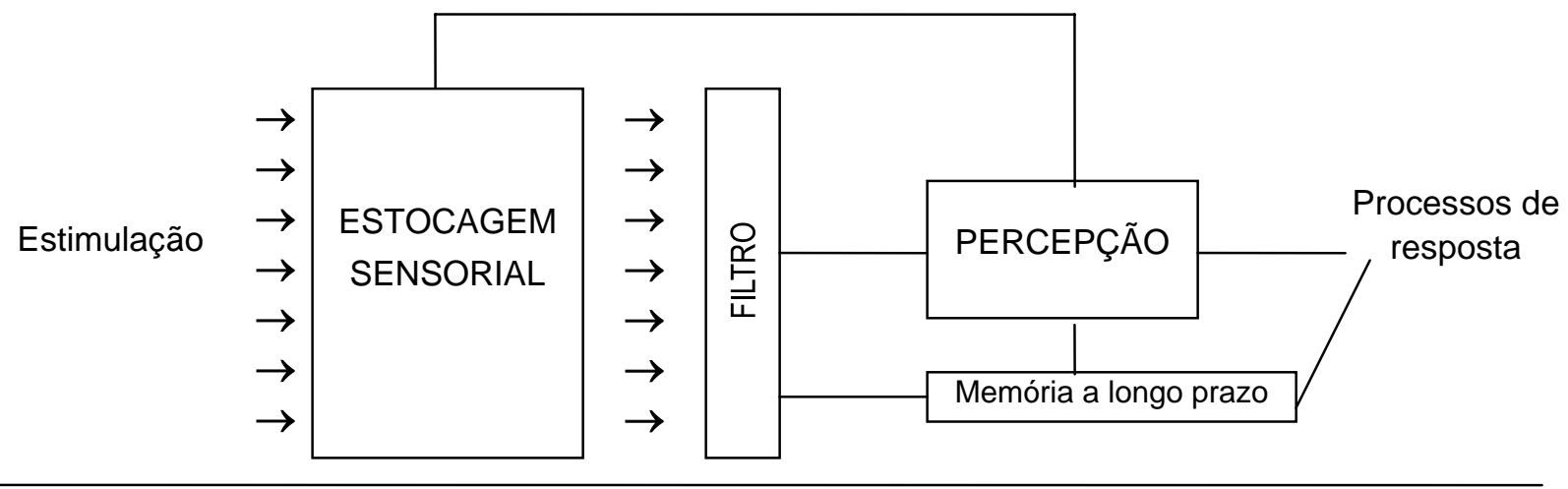

Fonte: Barber \& Legge, 1976, p. 91 
Uma vez que a informação tenha sido selecionada e enviada para o sistema de percepção, inicia-se a etapa seguinte, que segundo Barber \& Legge (1976), é a identificação desta informação, chamada de reconhecimento de padrões. Esse reconhecimento é realizado através da análise dos componentes elementares dos padrões, conhecida como análise de traços característicos. As teorias de análise de traços característicos têm sido utilizadas para descrever o reconhecimento de letras e da fala.

Uma outra forma de conceituar o processamento da informação, totalmente diferente dos modelos analíticos tradicionais, é a psicologia da Gestalt ou holística. Neste modelo, segundo Wertheimer (1958), citado por Barber \& Legge (1976), a percepção se dá de forma instantânea e qualquer análise que considere a fragmentação do sistema em processos componentes, estaria incorreta na sua concepção.

\section{5.2.2 Alguns fatores que influenciam a percepção}

A percepção da maior parte das pessoas é fortemente influenciada por aquilo que elas esperam e desejam ver. É praticamente impossível que as pessoas evitem o viés na percepção(Plous, 1993; Gibson \& Ivancevich \& Donnelly, 1988). Essa idéia é reforçada por Davidoff (1983), ao comentar que a percepção está longe de ser um espelho da realidade. Os sentidos humanos não captam muitos aspectos do ambiente e outras vezes percebem estímulos não presentes.

Para Skinner (1999), o ser humano percebe o mundo de acordo com as contingências às quais foi exposto. Essas contingências ou estímulos de reforço controlam o tipo de comportamento perceptivo das pessoas.

Bruner \& Postman (1949), citado por Plous (1993), realizaram alguns experimentos com percepção seletiva onde eram apresentadas às pessoas cinco cartas do baralho: um cinco de espada, um ás de copas, um sete de espada, um cinco de copas e um três com o símbolo de copas (coração), porém na cor preta. Eles observaram que as pessoas levavam quatro vezes mais tempo para reconhecer a carta fraudada (o três de copas na cor preta) do que as cartas normais e concluíram que as reações às incongruências podem ser de quatro categorias: 1) dominância, 2) compromisso, 3) rompimento ou 4) reconhecimento.

\section{1) Dominância}

A reação de dominância consiste no que foi chamado de "negação perceptiva". No experimento com as cartas, quando as pessoas viam um três preto de coração, estavam seguras que a carta era um três normal de coração (copas) ou um três normal de espada (preto). No primeiro caso, a forma era dominante e a cor era assimilada pela expectativa anterior; no segundo caso, a cor era dominante e a forma assimilada. 


\section{2) Compromisso}

Em experimento do mesmo tipo descrito anteriormente, porém, com outras cartas, $50 \%$ das pessoas demonstraram um compromisso com as cartas vermelhas e $11 \%$ com as pretas. Um quatro preto de coração (copas) parecia um quatro acinzentado de espada para alguns, enquanto para outros um seis vermelho de espada parecia um seis violeta de copas ou espada.

\section{3) Rompimento}

Quando a resposta, no experimento das cartas, era rompida, a pessoa tinha dificuldade de formar uma percepção de qualquer tipo. O rompimento é raro, mas quando ocorre, pode se tornar dramático; as pessoas ficam completamente desnorteadas.

\section{4) Reconhecimento}

Algumas pessoas durante o experimento conseguiam perceber que alguma coisa estava estranha, mas não sabiam o que seria. Não conseguiam reconhecer a fraude.

Os resultados destes experimentos mostraram que as expectativas podem influenciar fortemente a percepção. "Quando as pessoas têm experiência suficiente com uma determinada situação, elas freqüentemente vêem o que elas esperam ver" (Plous, 1993, p. 16).

McMillen \& Smith \& Wells-Parker (1989), citado por Plous (1993), realizaram outro experimento para analisar a influência da expectativa na percepção das pessoas. Os pesquisadores selecionaram aleatoriamente um grupo de alunos, os quais foram classificados em duas categorias: uma categoria de alto "gosto por sensação", que gostavam de assumir riscos e a outra categoria, de baixo "gosto por sensação". Em seguida, foi distribuído aos alunos, de forma randômica, um drinque que poderia ser uma bebida alcoólica ou não alcoólica. Meia hora após beberem seus drinques, os alunos foram convidados a participar de um vídeo game no qual eles dirigiam um automóvel numa estrada. Os alunos podiam ultrapassar outros carros através de um pedal de acelerador. Os alunos foram orientados para dirigir o carro simulado como se estivessem dirigindo um automóvel real. O resultado surpreendente do experimento é apresentado no quadro 2.8 .

\section{Quadro 2.8 Resultado do experimento sobre expectativa}

\begin{tabular}{|l|l|l|} 
Categoria do grupo & $\begin{array}{l}\text { Tipo de drinque que o aluno } \\
\text { acreditava ter bebido, } \\
\text { acertadamente ou não }\end{array}$ & $\begin{array}{l}\text { Comportamento durante a } \\
\text { simulação de dirigir na estrada }\end{array}$ \\
\hline
\end{tabular}




\begin{tabular}{|c|c|l|}
\hline $\begin{array}{c}\text { Alto gosto por } \\
\text { sensação }\end{array}$ & (1) Alcoólico & $\begin{array}{l}\text { Mais audacioso, ultrapassa mais } \\
\text { carros que (2) }\end{array}$ \\
\cline { 2 - 3 } & (2) Não alcoólico & $\begin{array}{l}\text { Menos audacioso, ultrapassa } \\
\text { menos carros que (1) }\end{array}$ \\
\hline Baixo gosto por & (3) Alcoólico & $\begin{array}{l}\text { Mais cauteloso, ultrapassa menos } \\
\text { carros que (4) }\end{array}$ \\
\cline { 2 - 3 } sensação & (4) Não alcoólico & $\begin{array}{l}\text { Menos cauteloso, ultrapassa mais } \\
\text { carros que (3) }\end{array}$ \\
\hline
\end{tabular}

Independente da bebida ingerida ser alcoólica ou não, os alunos passaram a se comportar durante a simulação de dirigir de acordo com suas expectativas. Quando acreditavam que a bebida ingerida era alcoólica, ainda que não fosse, tinham um tipo de comportamento e quando acreditavam que não haviam ingerido álcool, ainda que houvessem, tinham outro comportamento. O grupo de "alto gosto por sensação" teve comportamento inverso ao grupo de "baixo gosto por sensação", tanto quando acreditavam ter ingerido uma bebida alcoólica, como no caso de acreditarem que não haviam ingerido bebida alcoólica.

Para Plous (1993), este experimento caracteriza a forte influência das expectativas e crenças na percepção das pessoas. Esse tipo de influência é chamado pelos psicólogos de fator cognitivo. Mas a percepção, além de ser afetada pelo que a pessoa espera ver, também é afetada pelo que a pessoa deseja ver, isto é, desejos, esperanças e emoções constituem o chamado fator emocional, que também influencia a percepção. Neste sentido, Davidoff (1983), afirma que as percepções humanas dependem de expectativas, motivações e experiências anteriores. Gibson \& Ivancevich \& Donnelly (1988) observam que a percepção das pessoas pode ser influenciada por fatores emocionais e pela confiança que depositam em uma fonte de informação. 


\subsubsection{Heurísticas}

Slovic \& Fischhof \& Lichtenstein (1982), observam que na maior parte das vezes, as pessoas não utilizam evidências estatísticas para avaliar as situações de risco. Ao contrário, é comum o uso de regras gerais de inferência. Essas regras de julgamento, conhecidas como heurística, são empregadas para simplificar o processo cognitivo. Embora sejam válidas e úteis em determinadas circunstâncias, podem provocar grandes e persistentes vieses, com sérias implicações para a tomada de decisão.

Diversos pesquisadores, tais como, Baron (1994), Bazerman (1994), Russo \& Schoemaker (1993), e outros, têm apresentado uma extensa lista de heurísticas com base em pesquisas desenvolvidas sobre suas observações. A título de permitir uma idéia sobre a importância da heurística na percepção do risco, foram selecionadas algumas das principais heurísticas, oi seja: a) disponibilidade; b)caráter representativo; c) ancoragem.

a) A disponibilidade, segundo Tversky \& Kahneman (1973), citado por Bazerman (1994), consiste em fazer previsões de probabilidades, freqüências, ou de possíveis causas de um evento utilizando as ocorrências que estão disponíveis na memória. Os eventos que provocam emoções e foram vividos estarão mais disponíveis na memória do que aqueles isentos de emoção, vagos ou difíceis de se imaginar. "O gerente de produtos baseia sua estimativa de probabilidade de sucesso de um novo produto na sua lembrança dos sucessos e fracassos de produtos durante o passado recente" (Bazerman, 1994, p.7). Slovic \& Fischhof \& Lichtenstein (1982) consideram a heurística disponibilidade, como especialmente relevante para a percepção de risco e que o viés da disponibilidade pode ajudar o pesquisador a entender por que algumas pessoas apresentam percepções tão distorcidas.

b) O caráter representativo, de acordo com Bazerman (1994), baseia-se na utilização de estereótipos de ocorrência para avaliação da probabilidade de outras ocorrências similares. Os gerentes podem utilizar a heurística do caráter representativo para prever o desempenho de um funcionário, baseando-se na categoria de pessoa que aquele funcionário representa para ele. Assim como a disponibilidade, o caráter representativo também pode influenciar a previsão do gerente quanto ao sucesso ou fracasso no lançamento de um novo produto, baseando-se nas experiências passadas com tipos de produtos similares. Um problema que normalmente surge é que as pessoas tendem a confiar nestas 
estratégias, mesmo quando esta informação é insuficiente e existem outras informações melhores e mais confiáveis para se fazer um julgamento.

c) A ancoragem consiste em adotar um valor inicial para fazer uma estimativa que é ajustada posteriormente. A maioria das pessoas, conscientemente ou não, adotam o primeiro número que tem acesso. Segundo Russo \& Schoemaker (1993), o maior problema desta heurística é que, em geral, as pessoas não fazem o ajuste posterior necessário. O número inicial, ou âncora, afeta de tal forma o analista, que acaba impedindo o ajuste.

\subsubsection{A tolerância ao risco}

O termo tolerância pressupõe a existência de uma faixa de valores em que determinado objeto ou questão é aceita, isto é, a tolerância implica em limites para o seu estabelecimento. Neste sentido, considerando-se a teoria da utilidade esperada, onde admite-se que uma pessoa possa ser contrária, neutra ou propensa ao risco, a faixa de tolerância é mais extensa. No caso da teoria da perspectiva, onde o risco é considerado inerentemente repugnante, o termo tolerância fica prejudicado e provavelmente, ficasse melhor aplicar o termo comportamento face ao risco.

De acordo com Knight, citado por Pratten (1991), a criação de empresas é uma resposta à incerteza. A atividade econômica envolve um prognóstico do futuro e o ato de assumir o risco de que a previsão não estará correta.

\footnotetext{
Visto que as pessoas diferem na sua habilidade, ou disposição, em assumir riscos, aquela que é mais aversa a risco estará disposta a aceitar uma remuneração fixa e certa em retribuição à condição de seguir as ordens de outras. Os que são menos averso ao risco se tornam empreendedores, criam uma empresa e empregam aquelas pessoas que são aversas ao risco (Knight, 1921, citado por Pratten, 1991, p. 7).
}

Segundo Robbins (1990), citado por Maximiano (1997), a tolerância ao risco é um dos indicadores da cultura organizacional.

Existem pelo menos duas teorias distintas para se analisar a questão do comportamento das pessoas em face a uma situação de risco. A teoria da utilidade esperada e a teoria da perspectiva, ambas abordadas no item 2.5.4, onde se discutiu a questão da racionalidade da tomada de decisão. Neste trabalho foi adotada a teoria da utilidade esperada como ferramenta de medição da tolerância ao risco. 


\subsubsection{Como medir a tolerância ao risco}

Os problemas em análise de decisão, em geral, podem ser representados por árvore de decisão e diagrama de influência. De acordo com o manual do "Decision Programming Language", DPL (1995), a árvore de decisão é uma forma extremamente poderosa e intuitiva de representar a estrutura de decisão. A sua construção é simples e permite uma visão objetiva da estrutura do problema. Para analisar e decidir qual a melhor alternativa existem diversos critérios, sendo o mais comum o valor monetário esperado (Expected Monetary value, EMV).

Para construir uma árvore de decisão basta considerar as seguintes regras: um quadrado representa uma decisão; um círculo representa um evento incerto; as linhas que saem de um quadrado correspondem as alternativas de escolha do decisor; as linhas que saem de um círculo correspondem aos resultados possíveis de um evento incerto, e as conseqüências são colocadas nas linhas finais.

Clemen (1996) apresenta um exemplo de como utilizar uma árvore de decisão para representar um problema simples. Imagina-se que o decisor se defronta com a seguinte questão: existem dois jogos ${ }^{4}$ e apenas um deve ser escolhido, sendo que o jogo se realiza somente uma vez. O jogo 1 paga $R \$ 30,00$ se o jogador acertar e cobra $R \$$ 1,00 se errar. Supondo-se que o evento incerto seja o lançamento de uma moeda, existem 50\% de chance para cada alternativa. O jogo 2 é similar ao jogo 1, porém os valores são $\mathrm{R} \$ 2.000,00$ e $\mathrm{R} \$ 1.900,00$ respectivamente. Qual jogo o decisor deve escolher? Afigura 2.19 representa a árvore de decisão do problema proposto por Clemen.

Figura 2.19 Árvore de decisão e EMV
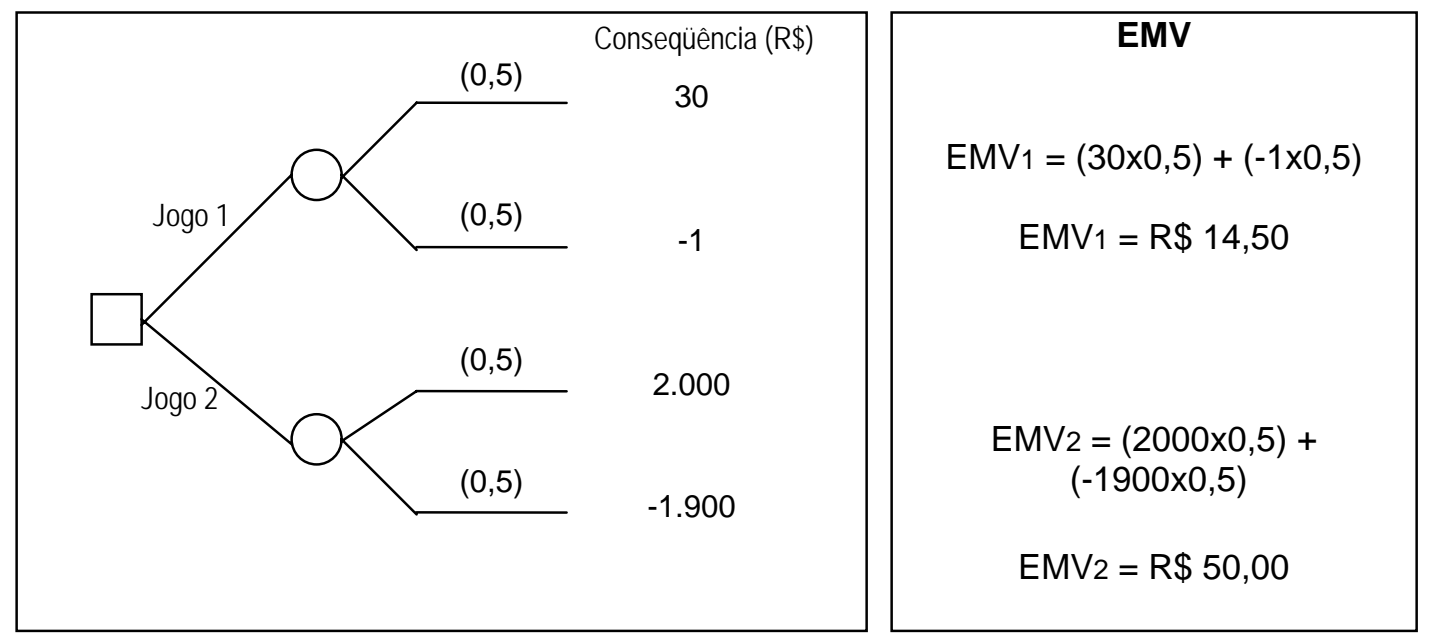

Fonte: Clemen (1996), p. 463

\footnotetext{
${ }^{4}$ Em teoria da decisão emprega-se a palavra jogo ou loteria, indiferentemente, para expressar uma situação que envolve eventos incertos e tomada de decisão.
} 
De acordo com o critério de maior valor monetário esperado, o decisor deve escolher o jogo 2, que oferece o maior EMV. Mas conforme observado por Clemen, este critério não leva em conta o aspecto risco. Supondo-se que o decisor não goste de correr risco, provavelmente a sua escolha seria o jogo 1, que oferece o menor risco.

Existem outros critérios para avaliar as alternativas de um problema, levando em conta a preferência do decisor. Um deles é o critério da utilidade esperada.

Para introduzir o conceito de equivalente certo, Bekman \& Costa Neto (1980) propõem o seguinte problema: o decisor tem que escolher entre duas alternativas: a) participar de uma loteria que oferece as possibilidades de se ganhar $\mathrm{R} \$ 1.000,00$, ou de não ganhar nem perder nada, cada uma das possibilidades com 50\% de chance; b) receber $R \$ 500,00$ sem participar da loteria. A figura 2.20 apresenta esta questão de forma esquemática.

Figura 2.200 equivalente certo

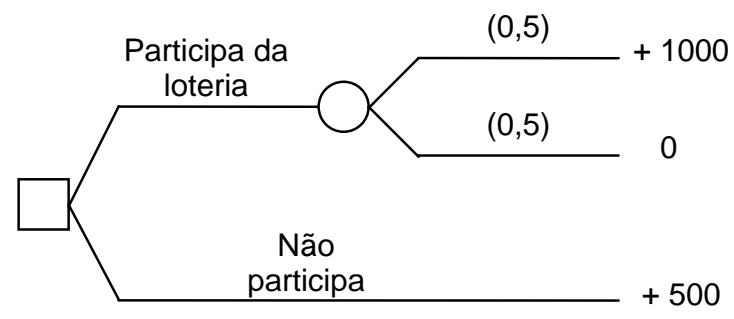

Do ponto de vista do valor monetário esperado, as duas alternativas são indiferentes, isto é, têm o mesmo EMV de 500. Nesta circunstância, muitas pessoas prefeririam a alternativa de receber $\mathrm{R} \$ 500,00$ sem o risco de não receber nada. Talvez, um bom número de pessoas aceitasse receber $\mathrm{R} \$ 400,00$ para não participar da loteria. A questão é saber quanto um indivíduo aceitaria para não participar da loteria, ou em outras palavras, qual o valor que torna esse indivíduo indiferente entre as duas alternativas. Esse valor é definido como o equivalente certo da loteria. "Evidentemente, diversos indivíduos terão diferentes equivalentes certos para a mesma loteria, como reflexo do fato de que diferentes pessoas ou entidades reagem diferentemente em relação ao risco" (Bekman \& Costa Neto, 1980, p. 55).

Utilizando o conceito de "equivalente certo" e aplicando diferentes loterias, é possível coletar alguns pontos da curva da função utilidade de um indivíduo. Em princípio, esta curva é o perfil de tolerância do indivíduo em relação ao risco monetário.

De acordo com a teoria da utilidade esperada de Von Neumann e Morgenstern, cada indivíduo tem uma preferência mensurável entre várias escolhas disponíveis numa situação de risco. Esta preferência é chamada utilidade e é medida com uma unidade arbitrária, chamada utilidades (Turban \& Meredith, 1994). 
A teoria da utilidade esperada permite que se calcule a utilidade que têm várias quantidades de dinheiro para uma pessoa ; isto é chamado de função utilidade do indivíduo. A representação gráfica desta função oferece o perfil da atitude do indivíduo frente ao risco.

A teoria da utilidade assume a hipótese que em qualquer decisão envolvendo risco, uma pessoa irá escolher a alternativa que maximize a sua utilidade esperada.

De acordo com Clemen (1996), a função utilidade de um indivíduo que tenha aversão ao risco pode ser representada graficamente por uma curva côncava, conforme a figura 2.21.

\section{Figura 2.21 Função utilidade que demonstra aversão ao risco}

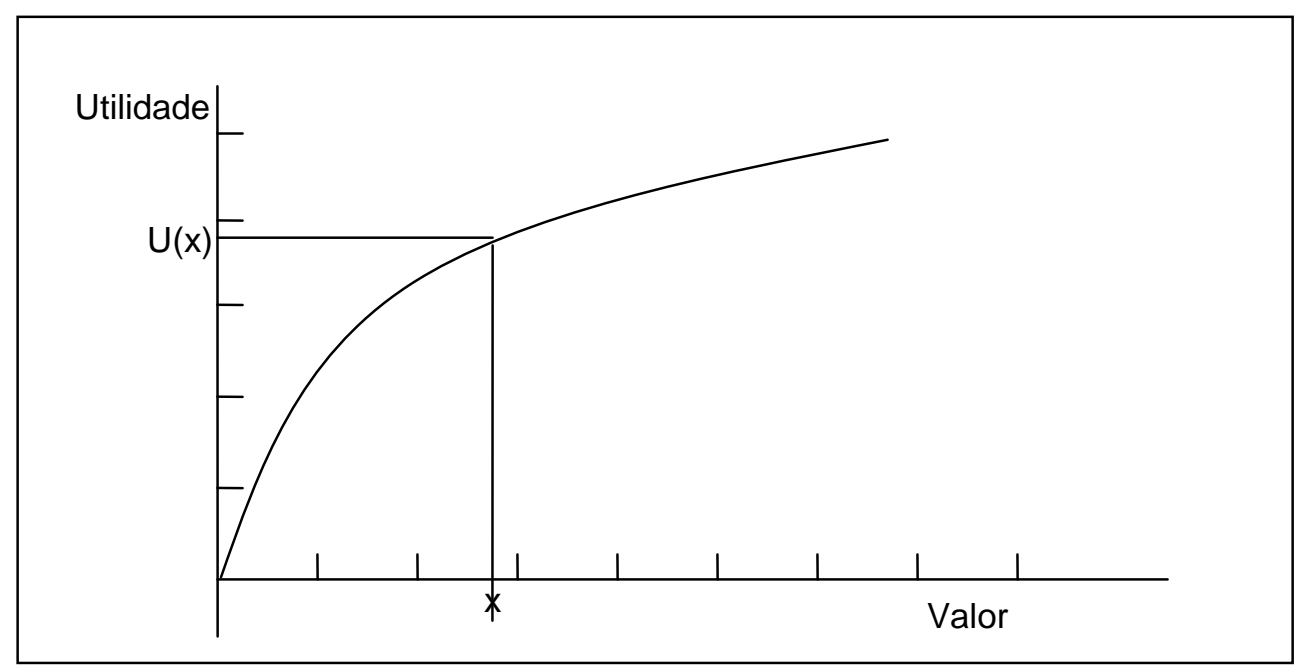

Fonte: Clemen (1996), p. 464

Segundo Clemen, a curva da figura 2.21 pode ser expressa pela função matemática $U(x)=1-e^{-x / R} \quad$ onde: $e=$ base dos logaritmos naturais $=2,718$ $\mathrm{R}$ = parâmetro que define como a função utilidade tem aversão ao risco. $\mathrm{R}$ é chamado de tolerância ao risco e quanto maior o seu valor menor a concavidade da curva, significando que o indivíduo tem menor aversão ao risco.

A figura 2.22 ilustra as três formas possíveis para a curva da função utilidade. 


\section{Figura 2.22 Formas diferentes da função utilidade}

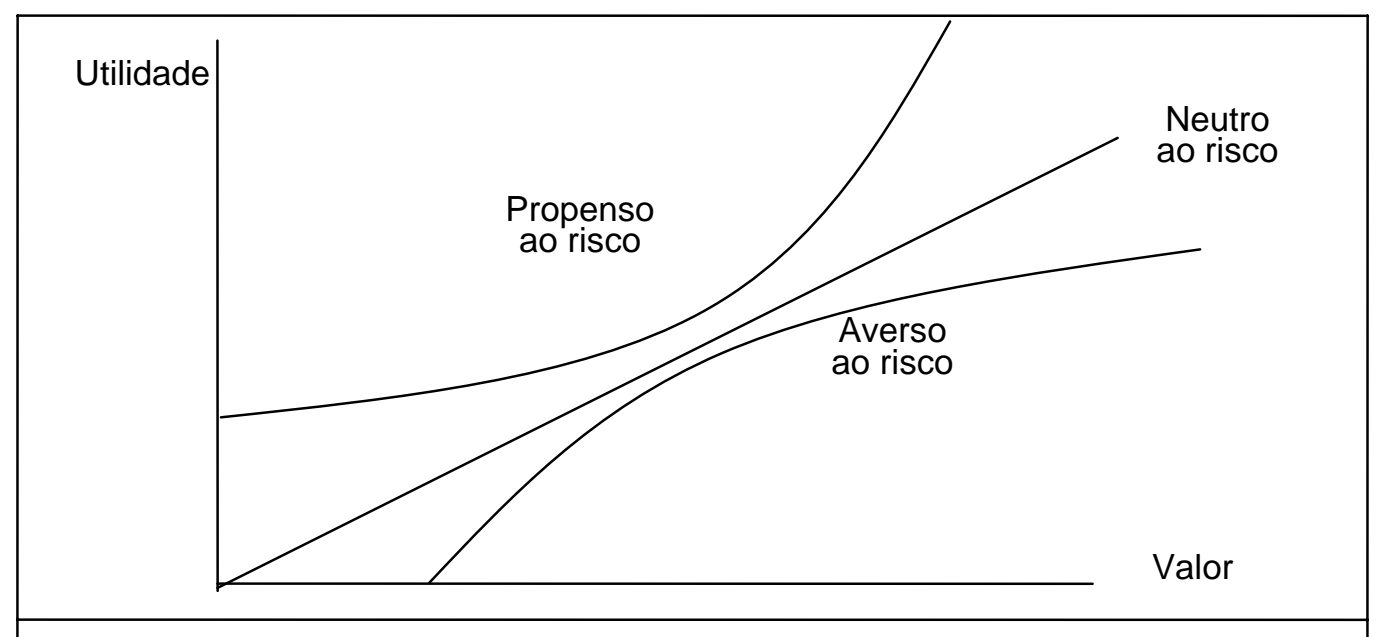

Fonte: Clemen (1996), $\mathrm{p}$

Golub (1997) observa que a função utilidade de algumas pessoas não podem ser representadas por uma das três curvas da figura 2.22. Em alguns casos a forma da curva se altera quando a riqueza aumenta, assumindo a forma da figura 2.23.

\section{Figura 2.23 Função utilidade quando a riqueza aumenta}

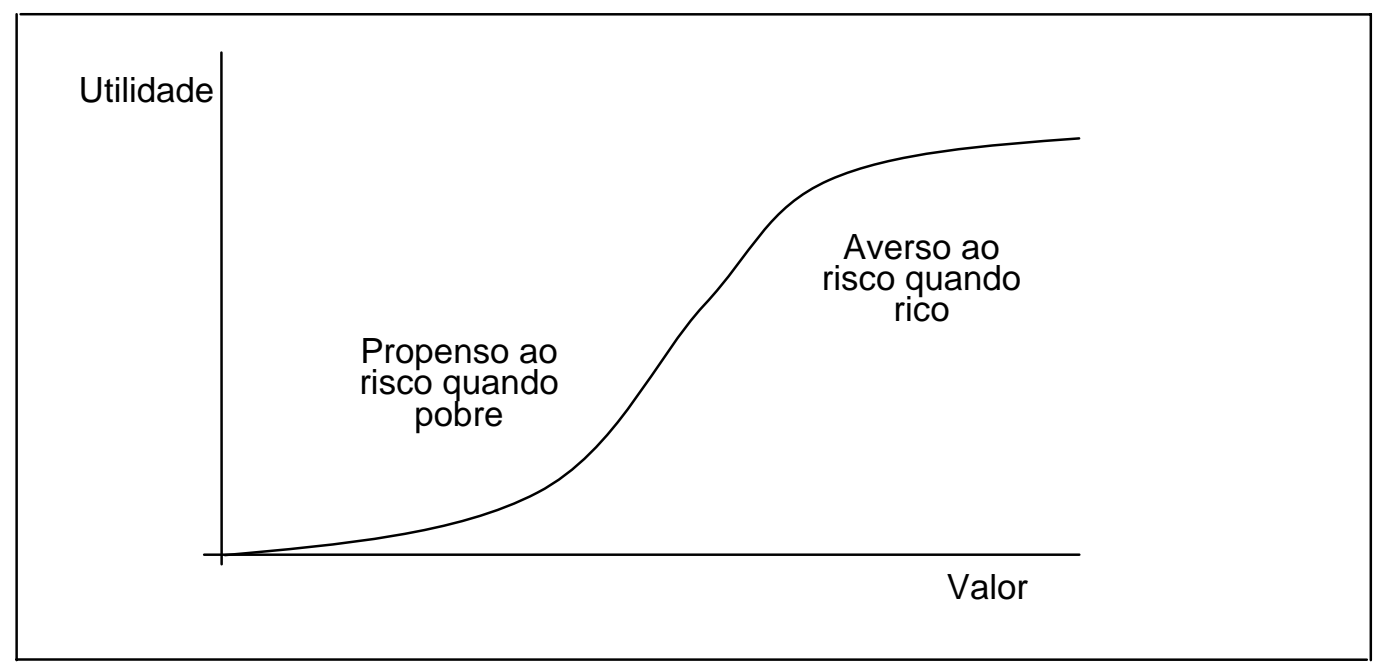

Admitindo-se que a expressão matemática: $U(x)=1-e^{-x / R}$ representa a função utilidade de uma pessoa, determinando-se o valor do parâmetro $\mathrm{R}$, a tolerância ao risco, é possível representar graficamente a função utilidade.

Segundo Clemen (1996), existem diversas formas de determinar o parâmetro R, a tolerância ao risco. Uma forma simples e que fornece um valor aproximado de R, é a seguinte: 
Admita a seguinte loteria: Quanto uma pessoa estaria disposta a arriscar, tendo $50 \%$ de chance de triplicar seu dinheiro (recuperar o que investiu e receber o dobro de prêmio) e $50 \%$ de perder tudo que investiu? Considerando que o indivíduo investe o valor (Y/2), a figura 2.24 apresenta a árvore de decisão desta questão.

Figura 2.24 Avaliação da tolerância ao risco

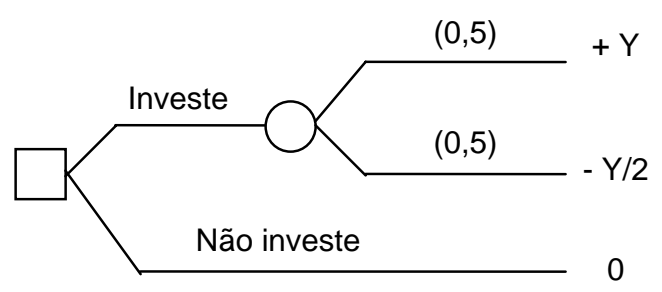

Segundo Clemen, o maior valor de $\mathrm{Y}$ para o qual o indivíduo prefere realizar o investimento ao invés de não realizá-lo, é aproximadamente igual ao parâmetro $\mathrm{R}$, a tolerância ao risco.

Quanto maior a tolerância ao risco, menos aversa ao risco é a pessoa e a sua curva da utilidade é menos côncava.

Howard (1988), relata um trabalho de consultoria sobre decisão que realizou para três empresas que eram parceiras numa joint venture utilizando este método:

"Nós começamos assumindo que a as preferências de risco deles eram exponenciais e então avaliamos as tolerâncias ao risco entrevistando os executivos do topo em cada empresa. Nós avaliamos a tolerância ao risco exponencial utilizando um procedimento simples e usual: nós encontramos a soma de dinheiro que cada executivo era indiferente na aplicação de um investimento da empresa com chance de 50-50 de ganhar aquela soma e de perder metade da soma. O resultado é uma boa aproximação à tolerância exponencial ao risco" (Howard, 1988, p. 689).

Howard (1988), sugere algumas diretrizes para determinar a tolerância ao risco de corporações em termo de vendas totais, lucro líquido, ou patrimônio. Valores razoáveis de R giram em torno de $6,4 \%$ das vendas, 1,24 vezes o lucro líquido, ou 15,7\% do patrimônio.

A função exponencial $U(x)=1-e^{-x / R}$, considera que o indivíduo ou organização tem uma aversão ao risco constante, isto é, independente da riqueza ou situação financeira deste indivíduo ou organização, qualquer loteria vai ser vista da mesma forma. 
Existem diversas considerações sobre a teoria da utilidade e modelos para determinar a tolerância ao risco. Bekman \& Costa Neto observam que:

“... há uma diferença real muito grande entre a situação de um indivíduo que é perguntado sobre sua opinião acerca de uma loteria, em relação à daquele que é de fato forçado a tomar uma decisão quanto à loteria em questão. [...] nota-se que as pessoas têm uma tendência de se mostrar mais tolerantes em relação ao risco quando se deparam com uma situação hipotética do que quando se vêem obrigadas a tomar uma decisão concreta" (Bekman \& Costa Neto, 1980 p. 57 e p. 68).

\subsubsection{A decisão racional}

A forma como uma pessoa pensa, segundo Baron (1994), afeta a maneira de planejar sua vida, os objetivos pessoais escolhidos e as decisões que são feitas. As pessoas desejam pensar racionalmente, no sentido de que a racionalidade significa adotar uma forma de conseguir alcançar os objetivos almejados.

Bernstein (1996) considera a racionalidade e a medição como fatores essenciais para a tomada de decisão sob incerteza. O autor argumenta que o comportamento racional faz com que as pessoas tratem as informações de forma objetiva e não tenham tendências obstinadas para o otimismo ou pessimismo; os erros quando ocorrem são aleatórios.

A racionalidade, segundo Baron (1994), diz respeito ao método de pensar que se utiliza, não às conclusões desse pensamento. Tanto para o pensamento como para as decisões, o autor considera que os métodos racionais são aqueles que geralmente melhor conseguem fornecer à uma pessoa o alcance de seus objetivos. Racionalidade não é o mesmo que exatidão e irracionalidade não é igual a erro. É possível utilizar bons métodos e se chegar à conclusão errônea ou utilizar métodos pobres e com sorte conseguir a resposta correta. As pessoas podem decidir racionalmente com base em crenças formadas irracionalmente.

Segundo Baron (1994), a racionalidade é freqüentemente contrastada com emoção. Neste caso, se o termo "emoção" estiver sendo usado como uma forma de tomar decisão sem pensar, então este contraste faz sentido. Mas quando a emoção participa da decisão, como por exemplo na condição de evidência, então não existe o contraste entre racionalidade e emoção.

Kay (1979) considera que a racionalidade não é um conceito simples de ser definido e faz uma distinção entre a racionalidade objetiva e subjetiva. Segundo Simon (1965), citado por Kay, uma decisão pode ser considerada objetivamente racional se de fato o seu comportamento levar a uma maximização dos valores em uma dada situação. Por outro lado, será subjetivamente racional se conseguir maximizar a capacidade relativa ao conhecimento atual de um determinado assunto. 
Para Baron (1994), a decisão racional pode ser definida em relação à uma pessoa, em um dado tempo, com um dado conjunto de crenças e objetivos. Da mesma forma, também é possível se falar em racionalidade de instituições sociais e de uma sociedade. Neste caso, o critério é se esses grupos tomam decisões coletivas que os levam a conseguir os objetivos de seus membros, tomados em conjunto. As decisões sociais são afetadas pelas práticas das instituições_a forma como estão organizados para tomar decisões_e pelas decisões dos indivíduos que compõem esse grupo. Pode-se julgar a racionalidade da decisão individual do ponto de vista do grupo, assim como do ponto de vista dos objetivos do próprio indivíduo. O julgamento feito a partir desses dois pontos de vista nem sempre são concordantes. Racionalidade é uma questão de grau. Faz sentido se dizer que uma forma de pensamento é mais racional que outra.

Segundo Plous (1993), um problema proposto por Nicolas Bernoulli em 1713, chamado de "Paradoxo de São Petersburg" e solucionado por seu sobrinho Daniel Bernoulli em 1738, foi a semente da teoria da decisão. O paradoxo de São Petersburg questionava por que as pessoas estavam dispostas a pagar tão pouco por um jogo quando o seu valor esperado era infinito. Este jogo consistia no lançamento de uma moeda não viciada, com as seguintes regras:

- a moeda é lançada até o resultado ser coroa;

- o jogador recebe $R \$ 2,00$ se o resultado for coroa no primeiro lançamento, $R \$ 4,00$ se for no segundo, $\mathrm{R} \$ 8,00$ no terceiro, e assim por diante.

O valor esperado deste jogo é:

$V E=(1 / 2)(R \$ 2,00)+(1 / 4)(R \$ 8,00)+\ldots+(1 / 2)^{a}(R \$ 2,00)^{a}=$ um valor infinito de dinheiro

Daniel Bernoulli argumentou que o valor ou utilidade do dinheiro diminui com a quantidade de dinheiro ganha ou já possuída. Assumindo que o valor do dinheiro adicional diminui com a riqueza, Daniel Bernoulli pode demonstrar que a utilidade esperada do paradoxo de São Petersburg não era infinito. A figura 2.25 ilustra o conceito de utilidade conforme proposto por Bernoulli. 


\section{Figura 2.250 conceito de utilidade}

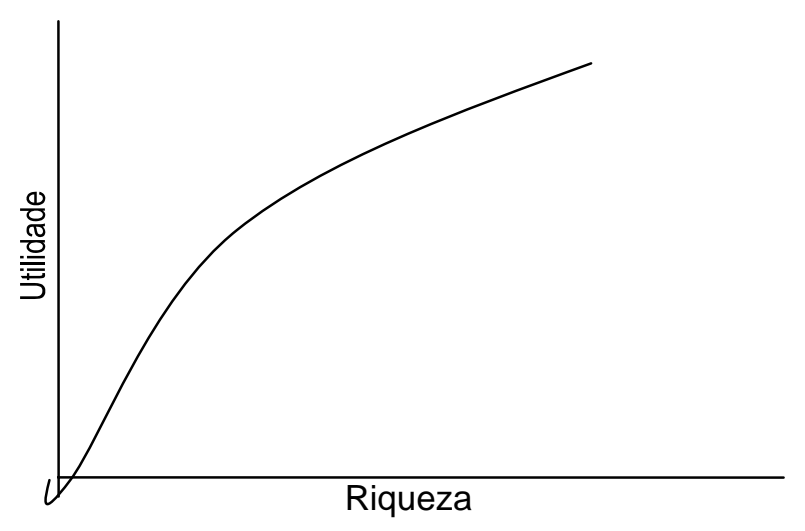

A teoria da utilidade esperada, segundo Plous (1993), foi apresentada por von Neumann \& Morgenstern (1947) com o principal propósito de definir um conjunto de premissas ou axiomas que caracterizariam o comportamento racional na tomada de decisão. Esta teoria não pretende descrever como as pessoas se comportam, mas como se comportariam se seguisse os requisitos da tomada de decisão racional. Nesse sentido, Berstein (1996) acrescenta que os modelos clássicos de racionalidade especificam como as pessoas deveriam tomar decisões e como seria o mundo se esse comportamento prevalecesse.

Segundo Plous (1993), os seis princípios que caracterizam o comportamento racional são:

\section{a) Ordenação das alternativas}

O decisor deve ser capaz de comparar duas alternativas quaisquer e deve preferir uma a outra ou ser indiferente.

\section{b) Dominância}

Uma estratégia ou alternativa dominante é aquela que quando comparada com outra produz um resultado superior em pelo menos um quesito e é tão boa quanto a outra nos outros quesitos. Admite-se que um decisor racional nunca escolheria uma estratégia que é dominada por outra.

\section{c) Cancelamento}

Se duas alternativas de risco possuem possíveis resultados idênticos e com a mesma probabilidade de ocorrência, então elas podem ser canceladas. 


\section{d) Transitividade}

Se um decisor racional prefere o resultado A ao B e prefere o resultado B ao C, então ele deve preferir o resultado $\mathrm{A}$ ao $\mathrm{C}$.

\section{e) Continuidade}

Para qualquer conjunto de resultados, o decisor racional deve sempre preferir uma loteria entre o melhor e pior resultado a um resultado intermediário certo se a probabilidade do bom resultado na loteria tiver um valor grande o suficiente.

\section{f) Invariância}

Este princípio estipula que o decisor racional não deve ser afetado pela forma como as alternativas são apresentadas.

A teoria da utilidade esperada, segundo Plous (1993), faz algumas simplificações para permitir um tratamento matemático às analises dos problemas. É assumido, por exemplo, que os decisores têm informações completas sobre as probabilidades e conseqüências dos resultados de cada alternativa de ação. A teoria também assume que os decisores entendem essas informações e são capazes de calcular as vantagens e desvantagens de cada alternativa, bem como comparar esses cálculos e escolher a alternativa que maximize a utilidade esperada.

Segundo Milgrom \& Roberts (1992), a premissa central das análises econômicas é que as pessoas têm um comportamento bem definido e descritível pela procura de maximização da sua função utilidade. Apesar de considerarem esse assunto controvertido, os autores acreditam que importantes aspectos de muitas organizações podem ser melhor entendidos através das tentativas deliberadas de mudar as preferências individuais.

Segundo Plous (1993), após von Neumann e Morgenstern apresentarem a teoria da utilidade, diversos outros estudiosos, tais como Savage (1954), Payne (1973), Fishburn (1984) e outros, desenvolveram extensões e variações desta teoria, de tal forma que hoje a teoria da utilidade esperada constitui uma família de teorias. Por outro lado, surgiram diversas alternativas à teoria da utilidade esperada, sendo que a mais conhecida dessas teorias é a "teoria da perspectiva", desenvolvida por Daniel Kahneman e Amos Tversky em 1979.

\footnotetext{
${ }^{5}$ O nome original é Prospect Theory; foi utilizado a tradução," teoria da perspectiva", conforme empregada por Berstein, 1997, p.270.
} 
Segundo Plous (1993), a teoria da perspectiva difere da teoria da utilidade esperada em alguns aspectos fundamentais:

1) Substitui a noção de utilidade por valor. Enquanto utilidade é normalmente definida como riqueza líquida, valor é definido em termos de ganhos e perdas.

2) A função valor para perdas é diferente da função valor para ganhos. Enquanto a função valor para perdas é convexa e relativamente achatada, a função valor para ganhos é côncava e não tão achatada.

3) Ao contrário da teoria da utilidade esperada, a teoria da perspectiva considera que as preferências dependem da forma que o problema é estruturado.

A figura 2.26 representa uma curva hipotética da função valor.

Figura 2.26 Uma curva hipotética da função valor na teoria da perspectiva

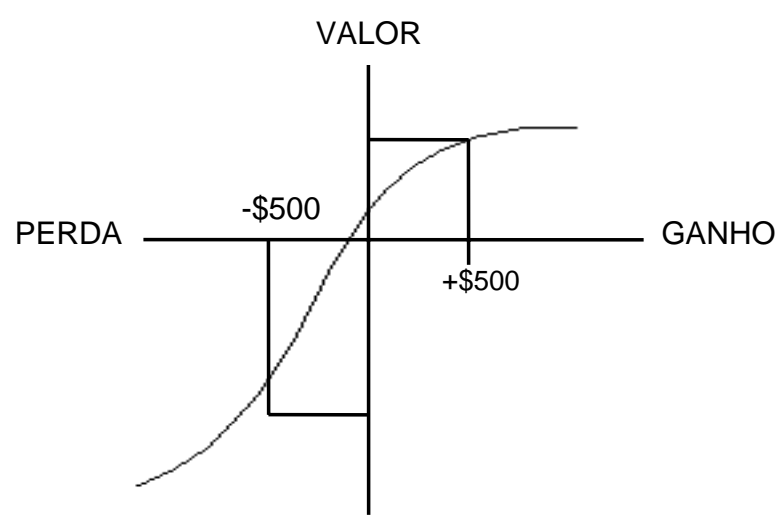

Fonte: Adaptado de Kahnemann \& Tversky, 1979, citado por Plous, 1993, p. 96

4) A teoria da perspectiva considera a preferência como uma função do "peso da decisão" e assume que esse peso nem sempre corresponde à probabilidade. A pequena probabilidade é super avaliada e a probabilidade moderada e alta é subavaliada. A figura 2.27 ilustra este fato. 
Figura 2.27 Peso da decisão hipotético de acordo com a teoria da perspectiva

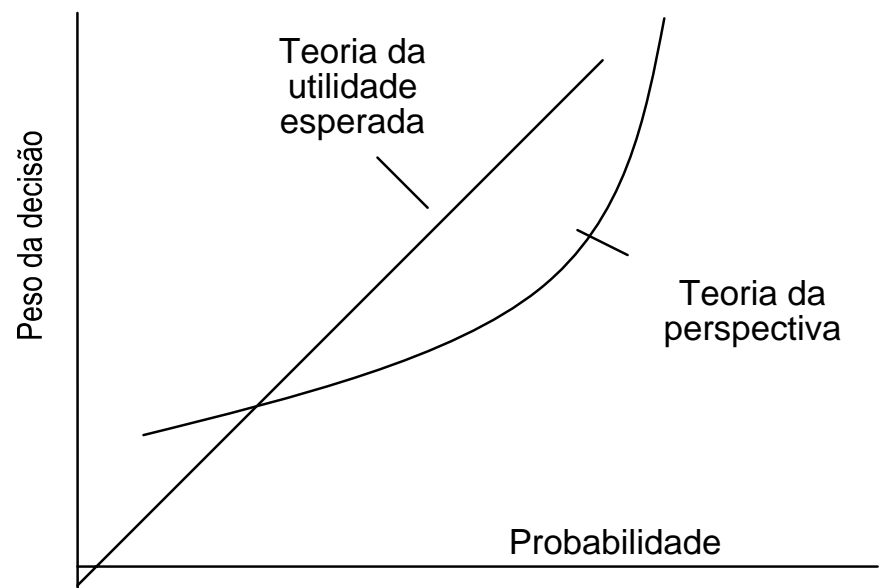

Fonte: Adaptado de Kahnemann \& Tversky, 1979, citado por Plous, 1993, p. 96

\subsubsection{A qualidade da decisão}

Decisões de má qualidade durante o processo de desenvolvimento de um novo produto provocam um resultado distante do almejado, ainda que outros fatores, tais como a sua estrutura, o planejamento e a alocação dos recursos estejam perfeitamente adequados.

Nenhuma quantidade de excelência em projetos ou agilidade da manufatura ou esforços em serviço ao cliente, por mais que sejam aplicados, podem salvar uma empresa cujos decisores a estejam conduzindo "fazendo as coisas erradas", isto é, desenvolvendo produtos indesejáveis ou produtos que não têm capacidade de serem aceitos pelo mercado. (Matheson \& Matheson, 1998, p. 3)

Segundo Baron (1994), aparentemente, as pessoas tendem a julgar a qualidade de uma decisão pelo resultado obtido. Matheson \& Matheson (1998) confirmam este tipo de comportamento, principalmente para aquelas pessoas que foram orientadas para a ação. 
Como é possível saber se a decisão é boa? Para responder esta questão, Matheson \& Matheson (1998) citam a resposta dada pelo Dr. Arno Penzias, prêmio Nobel e cientista chefe do laboratório da AT\&T:

\begin{abstract}
Os cientistas me perguntam, "Como você sabe que está trabalhando em um bom projeto?" Eu respondo, "Simples: imagine que aquilo que você está fazendo terá $100 \%$ de sucesso; encontre quanto se ganhará de dinheiro; multiplique pela probabilidade de sucesso, divida pelo custo, e olhe a figura da recompensa." Quando eu disse isso pela primeira vez, todos ficaram histéricos. Todos disseram, "Como poderíamos conhecer a probabilidade? Como poderíamos saber o valor ganho? O quê se não sabemos quem é o nosso cliente?"

Mas se você não sabe quem precisa de alguma coisa, por que você está fazendo esta coisa? Se você não sabe quais são as chances de sucesso, por que você está fazendo isto? Se você não sabe quanto irá custar não somente em recursos mas em anos de sua vida_por que você está fazendo isto? Você deve conhecer as três coisas!

(p. 23.)
\end{abstract}

Uma boa decisão, segundo Baron (1994), é aquela que faz uso efetivo da informação disponível por ocasião da tomada de decisão. Um bom resultado é aquele que agrada o decisor. O resultado pode ser o fruto de uma boa decisão, mas também pode ser conseqüência da sorte, seguindo uma má decisão

De maneira geral, a qualidade da decisão depende não do resultado e sim de como foi o processo de análise anterior à tomada da decisão. A teoria da decisão propõe que a melhor forma de tomar uma decisão é seguindo um conjunto de etapas, que basicamente são: estruturar o problema, criar alternativas factíveis, coletar informações e tomar a decisão. Assim, embora não existam garantias de bom resultado, do ponto de vista lógico, as chances de se conseguir o objetivo almejado são maiores.

Para conceituar o que é uma boa decisão, bem como analisar a relação entre decisão e administração da inovação, foi utilizada, neste trabalho, a teoria da decisão ${ }^{6}$. Conforme Clemen (1996), esta teoria, apesar de ter sua base nas leis da probabilidade e utilizar as ferramentas quantitativas, leva em conta os julgamentos pessoais sobre incerteza e os valores ${ }^{7}$ de grupos ou indivíduos.

Diversos autores (tais como Render \& Stair, 1994; Clemen, 1996; Russo \& Schoemaker, 1993; Bazerman, 1994; Hammond \& Keeney \& Raiffa, 1999; Matheson \& Matheson, 1998 e outros) têm apresentado estudos sobre tomada de decisões com a prescrição de modelos decisórios. Esses modelos, em geral, definem as etapas que devem ser adotadas para que se consiga uma boa decisão ou os cuidados para se evitar um viés

\footnotetext{
${ }^{6}$ A teoria da decisão, de acordo com Clemen (1996), é uma teoria tipicamente prescritiva; ao contrário de outras que são descritivas, ela propõe soluções para as questões pertinentes.

7 Valores aqui significam crenças sobre a vida e comportamentos aceitáveis. "Valores expressam as metas que motivam as pessoas e os caminhos apropriados para atingir essas metas" (Engel, Blackwell \& Miniard, 1995, p. 442). Neste trabalho foi utilizada a palavra "princípios" como sinônimo de valores.
} 
na decisão. Estes autores acreditam que existe um processo lógico para se tomar uma boa decisão e que este processo pode ser aprendido e exercitado por qualquer pessoa.

Alguns dos principais modelos prescritivos da tomada de decisão são:

- De acordo com Render \& Stair (1994), o processo de análise da decisão, independente do tipo ou importância desta, para ser executado adequadamente deve levar em conta as seguintes etapas:

1) Definição clara do problema;

2) Levantamento das possíveis alternativas;

3) Identificação dos possíveis resultados;

4) Cálculo do ganho de cada combinação de alternativas e resultados;

5) Seleção de um modelo quantitativo de análise;

6) Aplicação do modelo e tomada da decisão.

- Para Hammond \& Keeney \& Raiffa (1999) um processo de decisão para ser eficaz em qualquer tipo de solução de problemas deve aumentar a possibilidade de se conseguir um bom resultado e, ao mesmo tempo, atender a seis critérios:

1) concentração naquilo que é importante;

2) ser lógico e consistente;

3) reconhecer a existência de fatores objetivos e subjetivos, combinando o pensamento analítico com o intuitivo;

4) requerer apenas as informações e análises necessárias para solucionar determinado dilema;

5) encorajar e orientar a coleta de dados relevantes e opiniões bem informadas;

6) ser direto, confiável, de fácil uso e flexível.

Com base no atendimento aos seis critérios mencionados, os autores propõem um método chamado PrOACT, que é o acrônimo de Problem, Objectives, Alternatives, Consequences e Tradeoffs. O propósito deste acrônimo é ajudar o decisor a se lembrar dos cinco elementos e ao mesmo tempo reforçar a idéia de que a melhor abordagem na tomada de decisão é a proativa. Além dos cinco elementos citados, que compõem o núcleo central do método e servem para qualquer tipo de decisão, existem outros três elementos incerteza, tolerância ao risco e decisões interligadas - que ajudam a tornar clara as decisões em situações difíceis e instáveis.

O quadro 2.9 ilustra o método proposto. 
Quadro 2.9 Os elementos de uma decisão inteligente

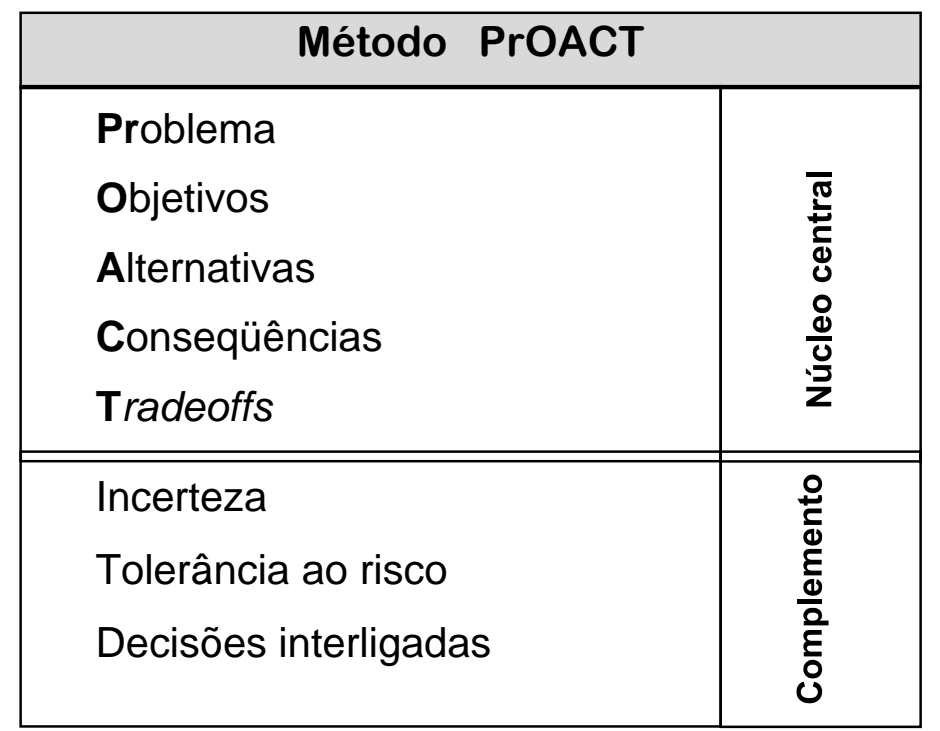

Fonte: adaptado de Hammond \& Keeney \& Raiffa, 1999, p. 5.

Para Clemen (1996), as etapas que compõem o processo de análise da decisão são basicamente as mesmas, incluindo-se uma etapa para análise sensitiva. O autor chama atenção para a interação entre as etapas. A figura 2.28 apresenta o modelo proposto por Clemen para o processo de análise da decisão. 
Figura 2.28 Fluxograma do processo de análise da decisão

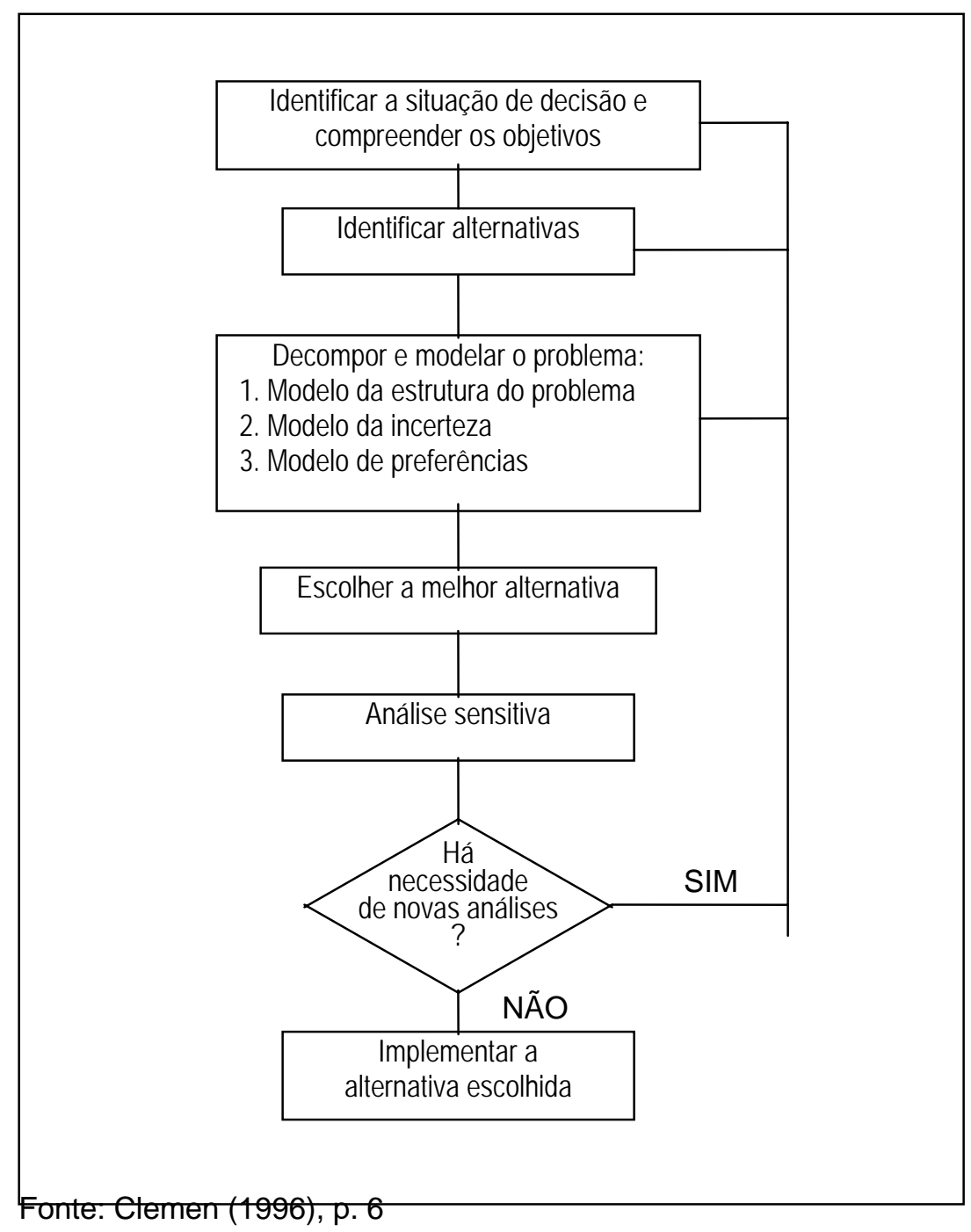

Russo \& Schoemaker (1993) propõem um modelo para auxiliar na tomada de decisão, baseado nas pesquisas acadêmicas sobre a forma que as pessoas processam informações. Essas pesquisas foram desenvolvidas durante mais de vinte anos por estudiosos, tais como Herbert Simon, Daniel Kahneman, Amos Tversky e outros, demonstrando que as pessoas, em diversos campos de atuação, tendem a cometer os mesmos tipos de erros. Os autores chamam esses erros de armadilhas à decisão e apresentam um método para evitá-las. O quadro 2.9 ilustra e sintetiza este método. 


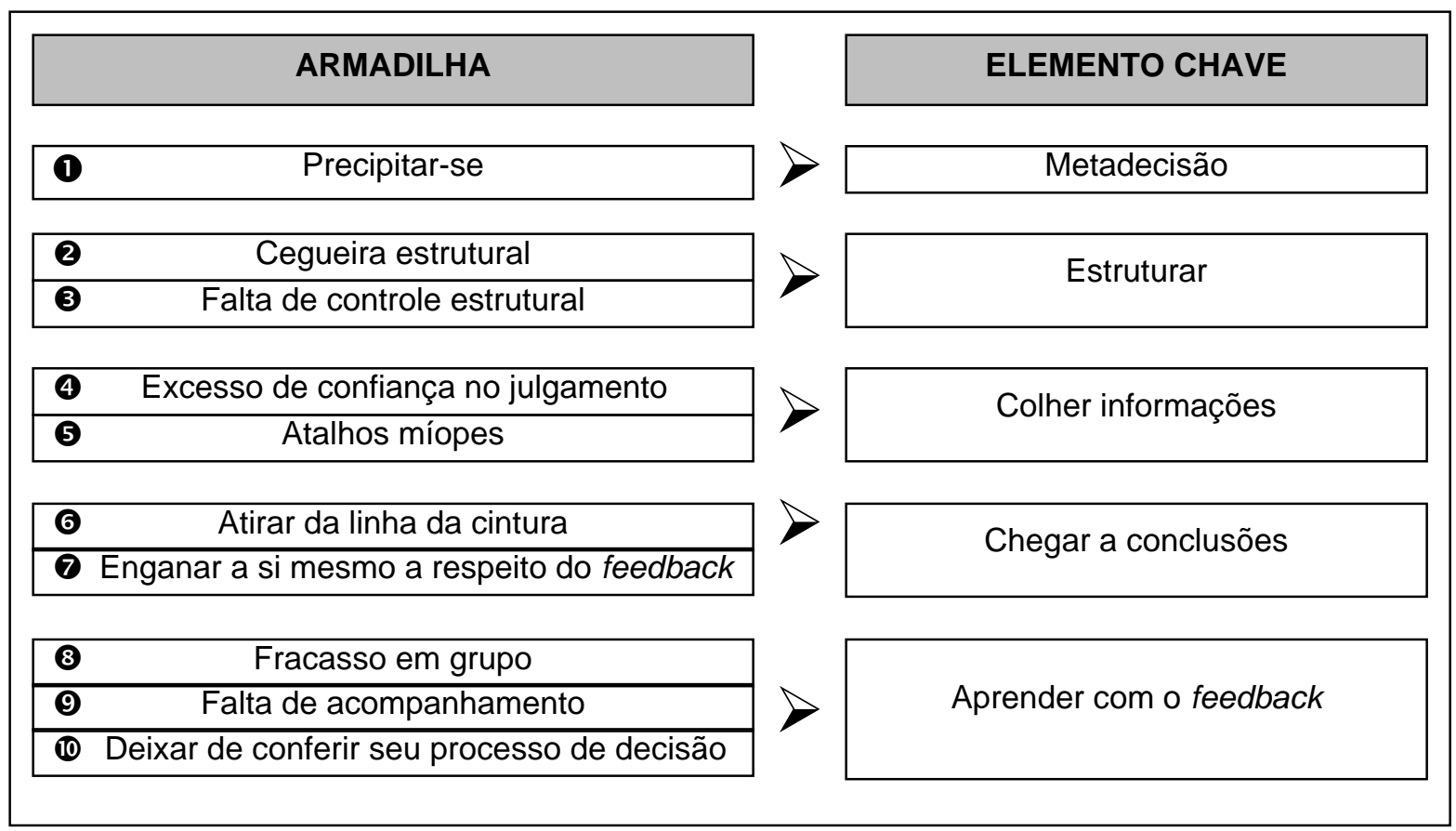

Os autores argumentam sobre a necessidade de se examinar o processo de decisão de forma sistemática, utilizando uma analogia entre o tomador de decisão e um atleta. Nos dois casos, o aperfeiçoamento do processo, através da conscientização e exercícios de eliminação dos erros, leva a um desempenho superior.

Para Russo \& Schoemaker (1993), os erros mais freqüentes, no caso chamados de armadilhas, são os seguintes:

\section{1) Precipitar-se}

Significa iniciar a pesquisa e coleta de dados sem antes gastar algum tempo analisando os aspectos mais importantes da questão. Antes mesmo da estruturação do problema deve-se questionar o próprio processo de decisão e buscar as opções possíveis. Este procedimento é chamado de "metadecisão", para designar um processo que transcende à decisão. Esta fase envolve perguntas do tipo: "Qual é o ponto mais importante desta questão?", "Essa decisão afeta muito as outras decisões?". A "metadecisão" tem por finalidade evitar a armadilha "precipitar-se". 


\section{2) Cegueira estrutural}

Todas as pessoas adotam estruturas mentais que simplificam e ordenam as informações encontradas no mundo para poderem tomar decisões. Ninguém pode tomar uma decisão racional sem um mínimo de estruturação. Por outro lado é preciso ter em mente que a estrutura é uma visão parcial do problema. $A$ cegueira estrutural nesta situação é a criação de uma estrutura mental sem muita reflexão e que não leva em conta os objetivos importantes e as melhores opções de ação. O resultado mais comum da cegueira estrutural é se partir para resolver o problema errado.

\section{3) Falta de controle estrutural}

Significa definir o problema de apenas uma forma ou se deixar influenciar indevidamente pelas estruturas dos outros problemas. O controle da estrutura é feito através das seguintes etapas: a) identificação da estrutura que é usada com mais freqüência; b) encontrar uma ou mais estruturas alternativas; c) analisar a utilidade de cada estrutura; d) escolher a estrutura que melhor se adapte ao problema.

\section{4) Excesso de confiança no julgamento}

Diversos estudos têm demonstrado que quase todas as pessoas confiam demais em sua opinião. O excesso de confiança está relacionado com o apego das pessoas a evidências que confirmem suas crenças e por outro lado a evitar as evidências contrárias. A sugestão, neste caso, é a auto-disciplina para buscar constantemente as informações que contestem a opinião dominante.

\section{5) Atalhos míopes}

Algumas heurísticas são de grande utilidade para ajudar a estruturar um modelo mental, mas em certas situações, essas mesmas heurísticas podem representar uma distorção ou miopia na coleta de informações. Basear-se indevidamente em regras práticas, tais como o excesso de confiança nas informações mais prontamente disponíveis ou se deixar inclinar em favor de evidências recentes, pode prejudicar todo o processo de decisão.

\section{6) Atirar na linha da cintura}


Significa acreditar que pode manter em mente todas as informações de que dispõe, improvisando a escolha em vez de adotar um procedimento sistemático.

\section{7) Fracasso em grupo}

Fatores como auto-censura, pressão sobre quem discorda da maioria, ilusão de invulnerabilidade e estereótipos errôneos podem conduzir pessoas, normalmente capazes, a cometerem erros quando trabalhando em grupo.

\section{8) Enganar a si mesmo a respeito do feedback}

Consiste em não reconhecer as evidências de fatos passados que, por alguma razão, não é conveniente. As pessoas, em geral, superestimam seu controle quando estão planejando uma ação ou relembrando um fato positivo, no entanto, subestimam seus erros quando se trata de uma ação que não deu certo.

\section{9) Falta de acompanhamento}

Ocorre com grande freqüência. Consiste em assumir que a experiência irá expor automaticamente suas lições, deixando assim de manter registros sistemáticos para acompanhar os resultados de suas decisões. Em desenvolvimento de novos produtos, as decisões mais importantes são tomadas no início do processo e, em geral, o processo é longo. O sucesso da análise e aprendizagem que podem ser realizada no final do projeto dependem essencialmente do registro sistemático das decisões tomadas.

\section{0)Deixar de conferir seu processo de decisão}

Significa não analisar a tomada de decisão para identificar os passos-chave e assim poder melhorá-la constantemente. Sem uma auditoria do processo de decisão o decisor corre o risco de continuar exposto às nove armadilhas mencionadas.

De acordo com Matheson \& Matheson (1998), a qualidade das decisões estratégicas depende diretamente de um conjunto de práticas, que por sua vez são fundamentadas em princípios adotados pela empresa. Este modelo de análise foi desenvolvido através de pesquisa realizada com aproximadamente duzentos e cinqüenta administradores de P\&D de diversas empresas americanas, de vários setores industriais. Nesta pesquisa foram identificadas as melhores práticas para sustentar a qualidade de decisão na administração de P\&D. 
Os autores argumentam que o contexto organizacional é fundamental para se implantar boas práticas e evitar as barreiras que podem surgir nesse processo. Este contexto é determinado por princípios que atuam de forma sutil em todos os níveis da organização, influenciando a forma de pensar e agir das pessoas.

Segundo os autores, os princípios que dão sustentação às melhores práticas de P\&D são os seguintes:

\section{1) Cultura de criação de valor}

O propósito da empresa é criar valor para os clientes e para ela própria e o desenvolvimento de novos produtos é visto como fator chave neste processo. Cada indivíduo vê o seu trabalho como gerador de valor.

\section{2) Geração de alternativas}

Escolher significa criar várias alternativas boas e selecionar a melhor. As pessoas normalmente geram boas alternativas e entendem quais agregam valor ao negócio.

\section{3) Aprendizagem contínua}

O propósito de uma organização é aprender continuamente o quê cria valor e como vendê-lo. As pessoas ficam motivadas pelo aprendizado e crescimento e procuram fazer o melhor para a empresa.

\section{4) Compreender e adotar incertezas}

As pessoas conhecem as fontes de incerteza e usam este conhecimento para tomar decisões. Elas sabem que as decisões podem ser controladas, mas o resultado não.

\section{5) Estratégia vista de fora para dentro}

A organização conhece a dinâmica do ambiente de negócio e usa esse conhecimento para avaliar as decisões estratégicas.

\section{6) Visão sistêmica}

As pessoas entendem a função desempenhada como uma parte do todo.

\section{7) Fluxo aberto de informações}

Todas as informações disponíveis para quem quiser. O fluxo de informações cruza as fronteiras funcionais.

\section{8) Alinhamento e iniciativa}

As decisões estratégicas são tomadas através de um processo participativo e alinhado com os objetivos da empresa.

\section{9) Tomada de decisão disciplinada}

Um processo pré-estabelecido é utilizado para as decisões mais importantes.

Matheson \& Matheson (1998) condicionam a qualidade da decisão estratégica a seis dimensões, conforme ilustrado na figura 2.29. 
Figura 2.29 Fatores relevantes da qualidade de decisão

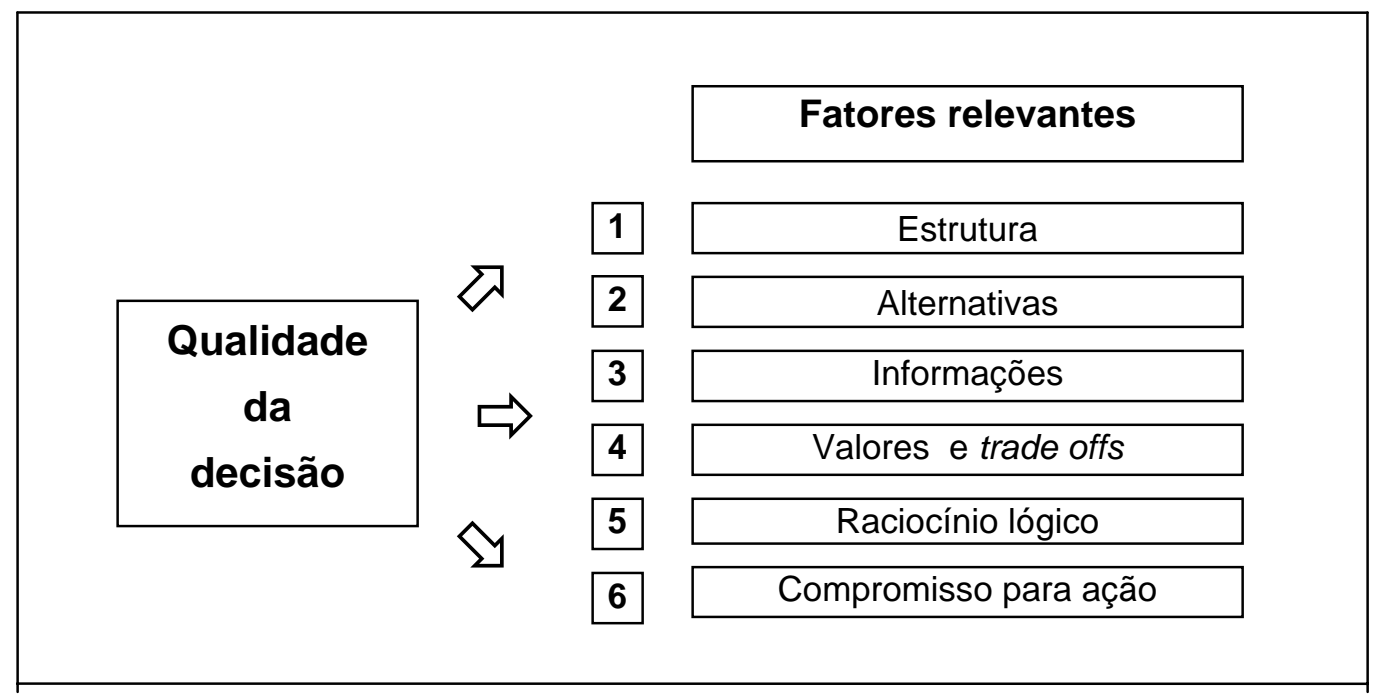

Os autores utilizam a analogia de uma corrente para expor o conceito da qualidade de decisão. Nesta analogia as dimensões da qualidade são os elos da corrente, significando que cada dimensão é uma parte imprescindível do conjunto. Em tal concepção, o resultado é definido pela dimensão mais fraca, como na corrente onde o elo mais fraco determina a sua capacidade.

As dimensões da qualidade apresentam as seguintes características:

\section{a) Estrutura da decisão}

Corresponde ao cenário do problema, com as principais questões colocadas de forma clara para se tomar a decisão. A estrutura é definida pelas questões, hipóteses, o propósito do negócio, e o pessoal envolvido. Os requisitos para uma estrutura de alta qualidade são:

- Não aceitar simplesmente o problema como apresentado na primeira vez.

- Estruturar de forma diferente os problemas estratégicos e operacionais.

- No nível estratégico, enfocar as atividades de P\&D como um investimento e não como despesas.

- Incluir múltiplas perspectivas no estabelecimento da estrutura de decisão. 


\section{b) Alternativas criativas e factíveis}

Esta é uma pré-condição para qualquer decisão. Sem alternativas não existe decisão. Os requisitos para atender a este item são:

- Gerar um conjunto de alternativas sem retratar velhas idéias.

- Separar a criação de alternativas da sua avaliação.

- Estar certo de que cada alternativa representa uma estratégia compreensiva e viável.

- Gerar alternativas que sejam substancialmente diferentes. Tipicamente deve haver entre três e sete alternativas.

\section{c) Informações significativas e confiáveis}

As empresas, em geral, sabem lidar com as informações conhecidas, mas nesse caso, é necessário ir além e buscar as informações desconhecidas que dêem sustentação à decisão. Os requisitos para este item são:

- Entender as incertezas presentes. Utilizar diagrama de influência ${ }^{8}$ para representá-las. Não confundir incertezas com ambigüidades.

- Quantificar as incertezas com faixas e não valores absolutos.

- Utilizar o melhor especialista com o menor viés. Utilizar procedimentos de estimação para minimizar ilusões cognitivas.

- Enfocar no material de informação para a decisão.

\section{d) Valores e trade-offs claros}

O ponto principal é ser claro sobre os objetivos e medir os projetos de forma consistente. A primeira providência para ser claro com os objetivos é separar os meios dos fins. Para analisar os trade-offs é necessário tratar separadamente o trade-off entre curto e longo prazo (preferência de tempo) do trade-off entre risco e retorno (preferência de risco). Os requisitos para este item são:

- Apreciar todas as alternativas com a mesma unidade de medida.

- A medida dos princípios deve representar o objetivo maior da empresa. Os intangíveis devem ser avaliados explicitamente.

- Os efeitos das decisões estratégicas devem ser transferidos diretamente das atividades do negócio para um fluxo de caixa.

- O custo do capital, sem ajuste para risco, deve ser usado como taxa de desconto para calcular o valor do dinheiro no tempo.

${ }^{8}$ Diagrama de influência é uma representação gráfica das situações de decisão. Os diferentes elementos de decisão são mostrados de diferentes formas geométricas. Estas figuras se interligam através de flechas que indicam o tipo de relação entre os elementos (Clement, 1996, p. 50). 
- O valor esperado deve levar em conta os diversos cenários para valorizar as perspectivas de incertezas.

\section{e) Raciocínio logicamente correto}

Considera as alternativas, informações, riscos, e princípios no contexto da estrutura de decisão e chega a uma conclusão baseada na evidência. Os principais requisitos para este item são:

- Mudar da lógica utilizada na política e na advocacia para a pesquisa científica e sistemática. Usar as ferramentas de análise de decisão para esclarecer os pontos chaves, não para defender pontos de vista.

- Utilizar um processo aberto. Sujeito às entradas e análises para críticas e revisões.

- Usar um processo quantitativo rigoroso.

- Começar com modelos simples. Usar os resultados e análise sensitiva para inspirar melhores alternativas.

\section{f) Compromisso com a ação}

Este compromisso é que justifica a tomada de decisão. O compromisso não é simplesmente ter o projeto aprovado; implica em haver uma intenção real de levar adiante o projeto. Os requisitos para este item são:

- Tanto os decisores como os implementadores da ação devem participar do processo de decisão.

- Qualidade de decisão, confiança e confidência devem ser desenvolvidas durante o processo.

- A qualidade nas outras cinco dimensões é necessária para um compromisso real. 


\section{CAPÍTULO 3}

\section{METODOLOGIA DE PESQUISA}

\subsection{A escolha da metodologia}

Não existe um consenso entre os diversos autores da área quanto à classificação da pesquisa científica ${ }^{9}$. Mattar (1996) observa que as diferentes classificações da pesquisa são resultantes da utilização de variáveis distintas. Assim, conforme a variável considerada, a pesquisa pode ser classificada em: a) qualitativa ou quantitativa; b) descritiva ou causal; c) exploratória ou conclusiva; d) por comunicação ou por observação; e) estudo de caso, estudo de campo ou levantamento amostral; f) ocasional ou evolutiva; g) experimental ou ex-post facto e h) realizada no campo, em laboratório ou por simulação.

Yin (1994) emprega a denominação estratégia de pesquisa para identificar o tipo de método e apresenta cinco possibilidades de estratégia: 1) experimento; 2) levantamento (survey); 3) análise de arquivo; 4) história e 5) estudo de caso. Cada uma destas estratégias pode ser usada com a finalidade exploratória, descritiva ou explanatória.

Para Davis (1996) existem quatro níveis de estudo científico, conforme o grau de entendimento que se busca da situação problema. Os níveis são: a descrição; a predição; a explanação e o controle. A descrição é a simples identificação das principais variáveis de um problema. A predição é realizada quando o pesquisador pode identificar uma variável ou um conjunto de variáveis que está associada com alguma outra variável. A explanação é conseguida quando o pesquisador pode responder, porque um certo fenômeno ou relação existe na realidade. O controle, que é o nível mais alto, existe quando o pesquisador está apto a manipular uma ou mais variáveis em uma situação problema para provocar mudanças em outras variáveis.

Segundo Schramm (1971), citado por Yin (1994), a essência de um estudo de caso é a tentativa de iluminar uma decisão ou conjunto de decisões através de questões do tipo: por que elas foram tomadas? Como foram implementadas? Qual resultado?

Para estudar a tomada de decisão em desenvolver novos produtos e processos na pequena indústria química foi escolhida a estratégia de estudo de caso.

\footnotetext{
${ }^{9}$ Podem ser citados como exemplo de autores que adotam diferentes classificações: Castro (1977), Kerlinger (1980) e Yin (1994).
} 


\section{A escolha deste método pode ser justificada pelos seguintes aspectos:}

\section{a) Pouca familiaridade do pesquisador com o assunto.}

Para Stake (1995), quando o objeto de pesquisa não está suficientemente compreendido pelo pesquisador, o estudo de caso lhe possibilita desenvolver sua compreensão do assunto. É comum denominar o trabalho de estudo de caso como "progressivamente enfocado".

\section{b) Tipo de questão proposta pela pesquisa.}

Para Yin (1994), o tipo de questão de pesquisa serve para orientar o pesquisador na escolha do tipo de pesquisa mais adequado. Assim, questões de pesquisa com base no pronome interrogativo "que" indicam a condução de um estudo exploratório, onde o objetivo principal é o desenvolvimento de hipóteses e proposições a serem posteriormente verificadas. As questões que utilizam "como" e "por que" são mais explanatórias e provavelmente mais adequadas às estratégias de estudo de caso, história e experimentos.

\section{c) A amplitude de controle do investigador sobre os eventos comportamentais.} De acordo com Yin (1994), o estudo de caso é a estratégia mais indicada quando não existe a possibilidade do investigador manipular os comportamentos relevantes, em um evento contemporâneo.

A pesquisa desenvolvida neste estudo se enquadra nestas condições.

Yin (1994) enfatiza que a estratégia de estudo de caso é uma forma de pesquisa empírica que investiga um fenômeno dentro do seu contexto da vida real, especialmente quando não está muito claro a fronteira entre o fenômeno e o contexto. Para o autor, esta estratégia de pesquisa pode tanto ser de caráter qualitativo como quantitativo.

Para desenvolver esta pesquisa foi escolhido a estratégia de estudo de múltiplos casos, na área das pequenas indústrias químicas com a finalidade explanatória, segundo a classificação de Yin (1994). No entanto, de acordo com a classificação proposta por Davis (1994) e Mattar (1996) esta pesquisa estaria melhor enquadrada como uma pesquisa exploratória, pois não possui o caráter conclusivo.

Foram pesquisados cinco casos, sendo um piloto. A figura 3.1 ilustra a forma como foi desenvolvida a pesquisa. 
Figura 3.1 Esquema do desenvolvimento da pesquisa

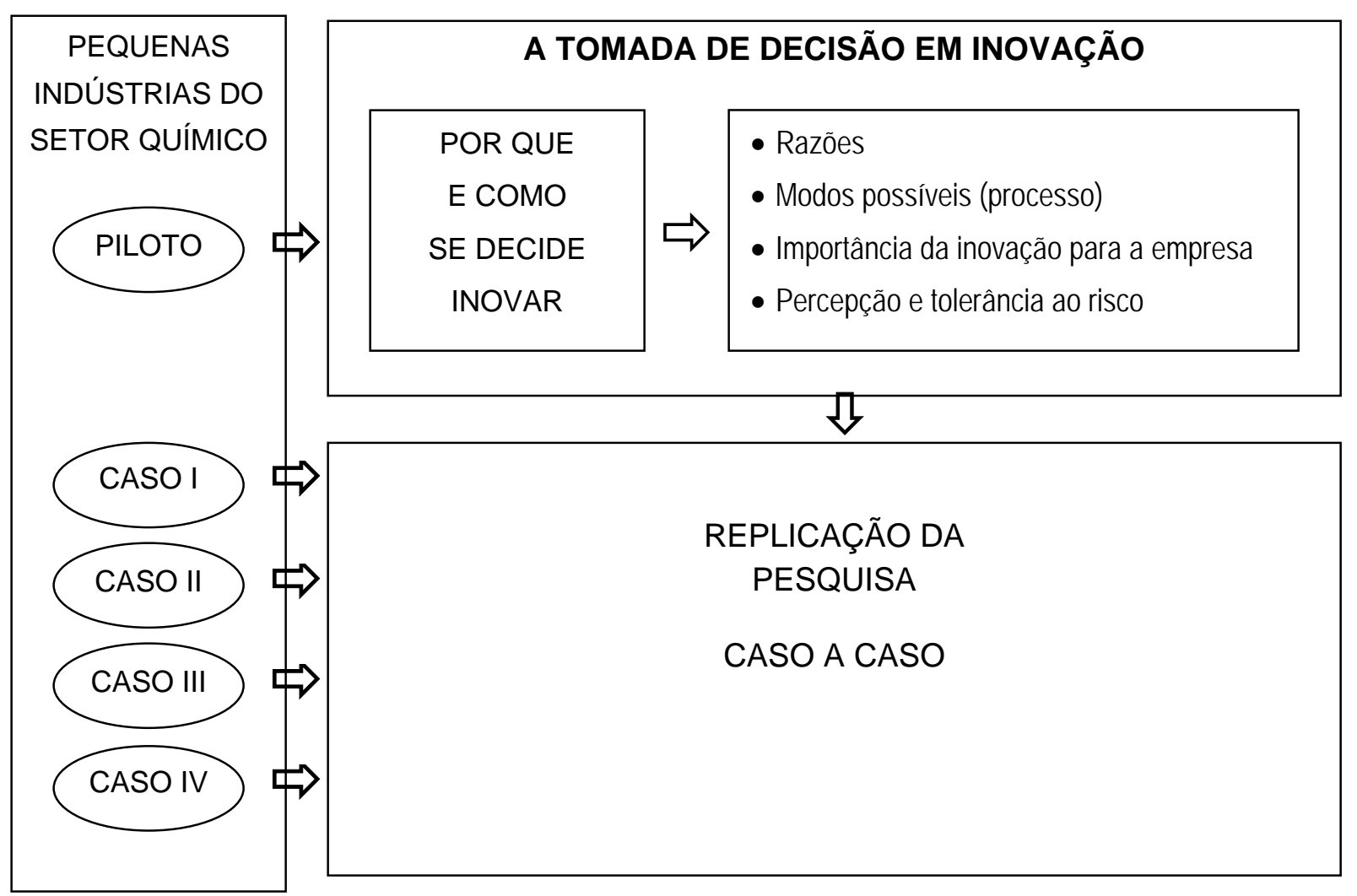

Neste estudo, foi escolhida a estratégia de múltiplos casos com base na característica da pesquisa. De acordo com Yin (1994), este tipo de estratégia se aplica quando:

1) Não existem as condições para o estudo de um único caso, ou seja, não se pretende realizar um teste crítico da teoria existente; não se trata de um evento raro e único; o caso não serve como um propósito revelador.

2) Cada caso, na estratégia de múltiplos casos, serve a um propósito específico dentro do escopo maior da pesquisa. De forma análoga, pode-se considerar os múltiplos casos como alguém consideraria múltiplos experimentos, isto é, utilizando a mesma lógica de replicação.

3) Cada caso, na estratégia de múltiplos casos, é cuidadosamente selecionado, de forma a atender a uma das seguintes proposições: a) predizer resultados similares (uma replicação literal) ou b) produzir resultados contrastantes, mas por razões previsíveis (uma replicação teórica). Nesta pesquisa pretendeu-se atender à segunda proposição, selecionando-se empresas que são nitidamente inovadoras e pelo menos uma considerada pouco inovadora. Esta avaliação prévia das empresas foi feita considerando-se a o tipo de negócio e a quantidade de novos produtos lançados no mercado durante os últimos anos. 
"A evidência proveniente de múltiplos casos é freqüentemente considerada mais forte, e o estudo na sua totalidade, por conseguinte, é visto como sendo mais robusto" (Herriott \& Firestone citado por Yin, 1984, p. 45).

\subsection{Critério para seleção dos casos}

Para determinar o número de casos estudados nesta pesquisa, levou-se em conta três aspectos:

a) A própria lógica da estrutura de pesquisa sugere ao menos dois casos: um para verificação das razões e formas de se decidir inovar em um ambiente inovador e o segundo, em ambiente pouco inovador;

b) A escolha discricionária de cinco casos, sendo um piloto, admitindo-se que este número de replicações está adequado ao nível de certeza que se espera obter com o resultado desta pesquisa;

c) As limitações de recursos para se desenvolver um grande número de casos, que, conforme observação de Yin (1994), podem tornar o estudo de múltiplos casos impraticável para estudantes ou pesquisadores independentes.

Considerando-se a inexperiência do pesquisador e o benefício de refinar o plano de coleta de dados, foi incluído um caso piloto entre os casos estudados. A escolha do caso piloto foi definida pelas características da empresa, ou seja, uma pequena empresa do setor químico com pelo menos cinco anos de atividade e que permitisse facilidade de acesso do pesquisador.

Para se estudar a tomada de decisão em inovação, em princípio, não haveria a necessidade de que as empresas fossem classificadas pelo seu porte. A bibliografia sobre tomada de decisão, em geral, faz apenas a distinção entre a decisão pessoal e empresarial, não se preocupando com o tamanho da organização. A opção por estudar a tomada de decisão apenas nas pequenas empresas foi assumida a partir de duas premissas: 1) pela evidência de que o processo de tomada de decisão na pequena empresa é substancialmente diferente daquele praticado pelas grandes empresas; 2) pela conveniência de estudar comparativamente processos mais homogêneos, limitando-se o ambiente de pesquisa ao conjunto de empresas desse porte.

Neste trabalho, com a finalidade de limitar o universo amostral, foi estabelecido que todos os cinco casos devem obedecer às condições de:

a) pertencer ao setor industrial químico; 
b) ser uma empresa de pequeno porte;

c) estar em atividade há pelo menos cinco anos.

Além dessas condições, procurou-se estabelecer uma escolha em função da graduação de quantidade de inovações que cada uma das quatro empresas produziam.

Uma questão importante, presente na maioria dos estudos sobre pequenas empresas, é o da definição ou classificação do que seja uma pequena empresa. Existem diversos critérios para classificação de empresas por porte, conforme a finalidade de uso da classificação (acadêmica, econômica, fiscal e outras), a própria cultura do país e outros fatores.

\subsubsection{Critérios de classificação do porte da empresa}

Para Rattner (1985), os critérios convencionais de classificação, tais como o número de empregados, faturamento e outros índices quantitativos, não estabelecem as categorias adequadas. Para o autor, a verdadeira dimensão que diferencia o porte das empresas é a mudança qualitativa na estrutura da empresa e no aprofundamento da divisão do trabalho. Nesse sentido, são apontadas algumas características da pequena empresa:

- A administração geral concentrada nas funções do proprietário;

- Recurso humano pouco qualificado e com pouca especialização dos cargos administrativos;

- Relações internas e externas da empresa do tipo essencialmente pessoal;

- Produção com programação pouco eficaz e não integrada com os outros setores da empresa;

- Ausência de sistemas de informação para tomada de decisão;

- Escassez de recursos próprios e dificuldade de financiamento;

- Tipo de participação no mercado, grau de concorrência e número de produtos comercializados;

- A gestão tecnológica. 


\subsubsection{Classificação por número de empregados}

O critério mais usual no Brasil tem sido o utilizado pelo SEBRAE (Serviço de Apoio às Micro e Pequenas Empresas) ou alguma variante dele. Esse critério considera como microempresa aquela que opera com até dezenove funcionários; pequena, quando o número de funcionários fica entre vinte e noventa e nove, sendo considerada uma empresa média ou grande, quando possui mais do que cem funcionários. O conjunto das micro e pequenas empresas é conhecido por MPE. Kruglianskas (1996) adota uma classificação semelhante, considerando pequenas empresas aquelas que têm menos de cem funcionários e como médias, aquelas com mais de cem e menos de quinhentos.

$\mathrm{Na}$ literatura e pesquisas acadêmicas americanas, em geral, o critério adotado para considerar uma empresa como pequena é que tenha menos de quinhentos funcionários.

Em seu artigo sobre as pequenas empresas da América Latina, Späth (1993) apresenta a classificação utilizada em pesquisas de diferentes países desta região. A tabela 3.1 apresenta as diferentes classificações citadas pela autora.

Tabela 3.1 Classificação da empresa em alguns países da América Latina

\begin{tabular}{|lccc|}
\hline \multirow{2}{*}{ PAÍS } & \multicolumn{3}{c|}{ Número de empregados } \\
\cline { 3 - 4 } & Pequena & Média & Grande \\
\cline { 2 - 4 } BOLÍVIA & $5-49$ & $50-99$ & $>100$ \\
BRASIL & $1-99$ & $100-499$ & $>499$ \\
CHILE & $1-49$ & $50-109$ & $>109$ \\
COLÔMBIA & $5-49$ & $50-99$ & $>100$ \\
EQUADOR & $5-49$ & $50-99$ & $>100$ \\
PERU & $5-19$ & $20-199$ & $>199$ \\
\hline
\end{tabular}

\subsubsection{Classificação legal}

Conforme a finalidade e o órgão ou instituição envolvida, existem diversas classificações legais. A título de exemplo, foi destacada uma classificação legal utilizada para tributação. De acordo com a Lei $n^{\circ} 9.317$, de 5 de setembro de $1996,{ }^{10}$ as condições de enquadramento como microempresa e empresa de pequeno porte são estabelecidas em

10 Para efeito de enquadramento tributário no Brasil, a partir de 1997, foi criado o SIMPLES, Sistema Integrado de Pagamento de Impostos e Contribuições, através da Lei $n^{\circ} 9.317$, de 5 de setembro de 1996. Segundo SILVA, D. S. \& GODOY, J. A. \& CUNHA, J. X. (1998), esta Lei tem conotação meramente fiscal e é opcional. 
função do faturamento, objetivo social, natureza jurídica, composição societária e outros aspectos legais. Quanto ao faturamento, microempresa é aquela que tem receita anual de até $R \$ 120.000,00$ e a empresa de pequeno porte é aquela que fatura, anualmente, acima de $R \$ 120.000,00$ e não mais que $R \$ 720.000,00$. Quanto à natureza jurídica, apenas as empresas constituídas sob a forma de sociedade por ações não podem ser enquadradas como microempresa ou empresa de pequeno porte.

\subsubsection{Outros critérios de classificação}

O Comitê de Desenvolvimento Econômico dos Estados Unidos (CED - Committee on Economic Development), citado por Pickle \& Abrahamsom (1990), estabelece que um negócio será classificado como pequena empresa se atender a dois ou mais dos quatro requisitos a seguir:

1) A administração é independente;

2) O capital é suprido e a propriedade é mantida por uma pessoa ou um pequeno grupo;

3) A área de operação é essencialmente local. Trabalhadores e proprietários habitam uma comunidade. O mercado não precisa ser local.

4) Tamanho relativo dentro do setor - o negócio é pequeno quando comparado à maior unidade do seu setor.

Outra organização americana, o SBA (Small Business Administration), utiliza um critério qualitativo de classificação semelhante ao adotado pelo CED e um critério quantitativo complementar, baseado nas vendas e número de empregados, separados por varejo, serviço, atacado, empreiteiras e manufatura.

\subsubsection{Critério adotado neste trabalho}

Considerando-se que a pequena empresa, em geral, tem a sua administração fortemente influenciada pelo perfil de administração do(s) seu(s) proprietário(s) e da sua gerência de topo, com a estrutura organizacional distribuída em poucos níveis hierárquicos, é possível inferir que as decisões estratégicas são de responsabilidade do topo da administração. Ao contrário, as grandes empresas, em sua maioria, possuem diversos níveis hierárquicos e uma grande divisão do trabalho administrativo, com a tomada de decisão estratégica diluída através de diversas pessoas. 
Como o foco deste estudo é a tomada de decisão estratégica em inovação, parece razoável que o critério adotado para classificação do porte da empresa seja baseado em:

\section{1) Quanto à forma que é tomada a decisão}

Pressupõe-se que as empresas escolhidas para serem pesquisadas estejam entre aquelas em que o diretor-presidente, seja ele o proprietário da empresa ou não, participe das decisões estratégicas relativas ao desenvolvimento de novos produtos ou processos. Caso essa premissa não se verifique, a empresa deve ser descartada.

\section{2) Tamanho relativo ao setor}

Para avaliar o tamanho da empresa em relação ao setor industrial químico, foi considerada a lista "1000 maiores empresas da América Latina" no levantamento feito pela Gazeta Mercantil em 1999. De acordo com esta pesquisa:

- A maior empresa brasileira do setor químico e petroquímico é a Petrobrás, Petróleo Brasileiro S/A, com uma renda operacional líquida em 1998 de $\mathrm{R} \$ 18$ bilhões.

- A maior empresa privada brasileira do setor químico é a Rhodia, com uma renda operacional líquida em 1998 de R\$ 1,6 bilhões.

- A menor empresa química brasileira que consta desse ranking teve, em 1998, uma receita operacional líquida de $\mathrm{R} \$ 27,8$ milhões.

Assim, presumindo-se que a grande maioria das empresas pertencentes a esse ranking sejam grandes empresas e apenas as últimas colocadas sejam de porte médio, foi adotado, de forma arbitrária, o seguinte critério: grandes empresas, quando a renda operacional líquida em 1998 for superior a R\$ 100 milhões; média, quando essa receita for menor que R\$100 milhões e maior que R\$10 milhões; e pequena, quando a receita for inferior a $\mathrm{R} \$ 10$ milhões.

\section{3) Número de funcionários}

Foi adotado o critério mais usual nos estudos brasileiros que considera empresa de pequeno porte, quando o número de funcionários for inferior a cem.

Finalmente, foi assumido neste trabalho que o enquadramento de uma organização como pequena empresa se dará quando pelo menos duas condições, das três estabelecidas, sejam atendidas, desde que a forma de tomar decisão seja uma delas. 


\subsection{A estrutura da pesquisa}

Neste item pretende-se abordar a forma como a pesquisa está estruturada, isto é, estabelecer quais são os dados que devem ser coletados, a ligação lógica desses dados com as questões de pesquisa e como analisar os resultados.

De acordo com Yin (1994), no estudo de caso são particularmente importantes os seguintes componentes: 1) as questões do estudo; 2) as proposições, se existirem; 3) a unidade de análise; 4) a ligação lógica entre os dados e as proposições e o critério para interpretar os resultados.

\subsubsection{Questões do estudo}

Para Stake (1995), a escolha das questões de pesquisa ajuda o pesquisador a definir suas fontes e atividades de coleta de dados. O autor ressalta, todavia, que estas questões devem ser revisadas com o andamento da pesquisa e, provavelmente, surjam daí novas questões.

Esta pesquisa aborda o processo de inovação na pequena indústria química, visando a obtenção de subsídios que possam ajudar no esclarecimento das seguintes questões:

\section{a) Por que se toma a decisão de desenvolver um novo produto ou processo? \\ b) Como é tomada a decisão de desenvolver um novo produto ou processo?}

\subsubsection{Proposições do estudo}

Para Yin (1994), as proposições auxiliam o pesquisador na direção daquilo que deve merecer maior atenção dentro do escopo do estudo. Porém, o autor adverte que é perfeitamente possível um estudo sem proposições prévias, definindo-se apenas um propósito.

Nesta pesquisa, considerando-se como uma forma de concentrar a atenção no objeto de estudo, muito mais do que na busca de comprovação ou negação do seu enunciado, foi feita a seguinte proposição: "A decisão de desenvolver um novo produto é tomada principalmente em função de: a) contexto no qual a indústria se insere; b) percepção do risco; c) tolerância ao risco do(s) decisor(es)". 


\subsubsection{Unidade de análise}

Yin (1994), propõe, como uma orientação geral que a definição da unidade de análise esteja relacionada à forma como as questões de pesquisa foram definidas. No caso deste estudo, tomando-se por base as questões de pesquisa, definiu-se a unidade de análise como sendo a tomada de decisão da pequena indústria química em desenvolver um novo produto ou processo.

Esta definição da unidade de análise, por si só não fornece os limites da pesquisa, uma vez que, durante o processo de desenvolvimento de uma inovação são tomadas inúmeras decisões e cada empresa pode ter diversos projetos de inovação. Para estabelecer, da forma mais clara possível, os limites da unidade de análise, foi adotado o modelo de desenvolvimento de uma inovação proposto por Tidd, Bessant \& Pavitt (1997).

Considerando-se este modelo, foi definido como unidade de análise deste trabalho o conjunto das decisões tomadas, em um determinado projeto de inovação, nas duas fases iniciais: o processamento do sinal e a estratégia. Nessas duas fases foram consideradas as decisões que melhor definissem a decisão de investir no novo produto ou processo, conforme ilustrado na figura 3.2. Em geral, essas decisões estão relacionadas com um compromisso de ação, que por sua vez implica comprometimento de recursos.

Figura 3.2 Identificação da unidade de análise

\begin{tabular}{|c|c|c|c|c|}
\hline & FASES & & & \\
\hline $\begin{array}{l}\text { A } \\
\text { T } \\
\text { I } \\
\text { V } \\
\text { I } \\
\text { D } \\
\text { A } \\
\text { D } \\
\text { E } \\
S \\
\text { S }\end{array}$ & $\begin{array}{l}\begin{array}{l}\text { Processamento } \\
\text { do sinal }\end{array} \\
\text { Fazer uma varredura } \\
\text { do ambiente para } \\
\text { coletar sinais } \\
\text { tecnológicos, do } \\
\text { mercado e outros } \\
\text { Processar os sinais } \\
\text { em informações } \\
\text { relevantes para a } \\
\text { tomada de decisão }\end{array}$ & $\begin{array}{l}\quad \text { Estratégia } \\
\text { Analisar, escolher, } \\
\text { planejar } \\
\text { Avaliar custos e } \\
\text { benefícios de diferentes } \\
\text { opções } \\
\text { Selecionar as opções } \\
\text { prioritárias } \\
\text { Ajustar e comprometer } \\
\text { recursos }\end{array}$ & $\begin{array}{l}\quad \begin{array}{l}\text { Alocação de } \\
\text { recursos }\end{array} \\
\text { Obter soluções } \\
\text { alinhadas com decisões } \\
\text { estratégicas }\end{array}$ & $\begin{array}{l}\text { Implementação } \\
\text { Desenvolver para } \\
\text { maturidade } \\
\text { Lançar e comissionar } \\
\text { Dar suporte após venda }\end{array}$ \\
\hline
\end{tabular}

Fonte: Adaptado de Tidd, Bessant \& Pavitt (1997), p. 41. 
A escolha do projeto de inovação a ser estudado foi feita pela empresa, observandose as seguintes condições:

- Um desenvolvimento de produto ou processo ocorrido nos últimos dois anos;

- Que estivesse pelo menos na fase de alocação de recursos, isto é, poderia estar em andamento ou já ter sido concluído;

- Que fosse importante para a empresa;

- Que os fatos ainda estivessem vivos na memória dos entrevistados.

\subsubsection{Ligação lógica entre os dados e a proposição e critério de análise}

Os dados coletados para análise das questões de pesquisa e proposição podem ser classificados em seis grupos:

\section{1) Informações preliminares e planejamento da pesquisa}

São os primeiros dados coletados sobre a empresa. Basicamente, servem para fornecer uma visão geral do negócio e da empresa. Com estes dados é possível a verificação do enquadramento da empresa no propósito da pesquisa e realizar o planejamento do trabalho. As principais informações são: atividade da empresa, número de funcionários, a ordem de grandeza do faturamento em 1998 e quem participa das decisões estratégicas em inovação. Constam desse grupo as diversas informações contidas no documento "Roteiro para entrevista preliminar".

\section{2) Informações gerais}

São os dados sobre as diversas áreas da empresa, tais como produção, finanças, recursos humanos, marketing e desenvolvimento de produtos e processos. Esses dados são fundamentais para a elaboração da descrição de cada caso. Estas informações estão contidas no documento "Questionário - Informações gerais".

\section{3) Informações sobre a inovação}

Neste grupo de dados busca-se aprofundar o conhecimento sobre o processo de inovação na empresa. São nove questões propostas com a finalidade de pesquisar: 
- Objetivo maior da empresa e a relação deste com a inovação;

- A visão da empresa sobre a importância da inovação para o seu negócio;

- As possíveis razões para a empresa inovar;

- Os benefícios e dificuldades da inovação.

Algumas questões foram colocadas de forma aparentemente redundantes, com a finalidade de permitir uma análise de consistência das respostas. O documento "Roteiro para entrevista - inovação" contém as informações desse grupo.

\section{4) Informações sobre a tomada de decisão}

São os dados sobre o processo de tomada de decisão para uma determinada inovação, escolhida pela empresa e desenvolvida durante os últimos dois anos. Esses dados devem permitir uma análise, com a maior profundidade possível, sobre as etapas iniciais do processo de desenvolvimento de um novo produto ou processo, com a finalidade principal de se conhecer como foi tomada a decisão de inovar. As questões propostas seguiram o modelo de Matheson \& Matheson (1998) para análise da qualidade de decisão. Neste caso, entretanto, serviu para coletar os dados não só da qualidade como sobre todo o processo de tomada de decisão. Os dados deste grupo constam do documento "Roteiro para entrevista - tomada de decisão".

\section{5) Informações sobre a percepção do risco}

A percepção de cada entrevistado foi avaliada através da aplicação de um teste. Este teste consta basicamente da apresentação de uma situação problema, em que o entrevistado deve apresentar a sua percepção. A situação problema descreve um cenário típico de tomada de decisão em inovação relativo àquela empresa. O dado obtido é a avaliação da probabilidade de fracasso da decisão, segundo o entrevistado, que representa uma medida da percepção do risco. Esta informação é coletada através do documento "Roteiro para aplicação do teste de percepção".

\section{6) Informações sobre a tolerância ao risco}

De forma análoga à percepção, a tolerância ao risco dos entrevistados foi medida através de um teste. Neste teste é apresentada uma situação problema sobre a tomada de decisão em inovação, semelhante às que a empresa têm. A decisão 
tomada pelo entrevistado, segundo Clemen (1996), reflete a sua tolerância ao risco. Esta decisão é uma medida expressa em valor monetário. O documento "Roteiro para aplicação do teste de tolerância" estabelece as condições deste teste.

As questões de pesquisa e a proposição deste trabalho estão relacionadas com os seguintes pontos:

- Por que se toma a decisão de inovar;

- Como se toma a decisão de inovar;

- Contexto no qual a empresa se insere;

- A percepção do risco;

- A tolerância ao risco.

A figura 3.3 apresenta esquematicamente a relação lógica dos quatro pontos mencionados.

Figura 3.3 A tomada de decisão em inovação

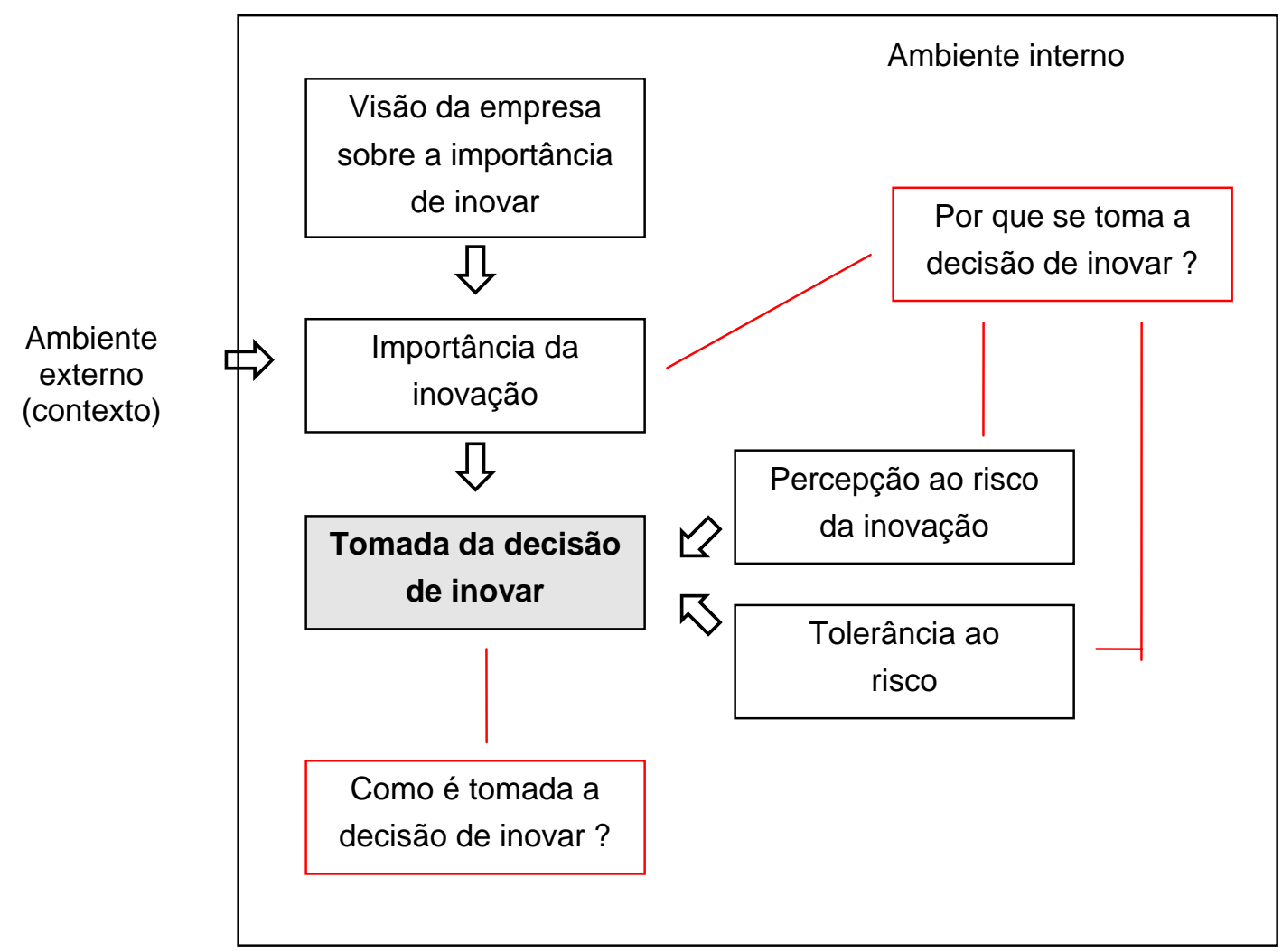


No esquema de estudo idealizado, a questão do por que se toma a decisão de inovar é analisada sob a visão de três diferentes fontes:

a) A vontade pessoal do decisor expressa através da percepção e tolerância ao risco;

b) A vontade da organização, através da importância que é dada à inovação;

c) A vontade do ambiente externo, que direta ou indiretamente influencia a importância da inovação.

Além desta análise do "porque" é verificado o grau de racionalidade da decisão. Esta verificação é feita questionando-se o entrevistado sobre a relação entre a decisão e os objetivos maiores da empresa. Segundo Baron (1994) a decisão racional é aquela que é tomada para melhor atender os objetivos do decisor.

A questão de como se toma a decisão de inovar é analisada com as informações obtidas sobre o processo de tomada de decisão de um determinado projeto, previamente escolhido pela empresa. A ênfase, neste caso, está nas fases iniciais do processo, a geração das idéias e a seleção dessas idéias, que coincidem com as etapas processamento do sinal e estratégia, previstas no modelo de Tidd, Bessant \& Pavitt (1997). Esta análise envolve vários aspectos do processo de decisão, tais como quem participa do processo, qual o nível de estruturação, o tipo de inovação e a qualidade.

A avaliação da qualidade da decisão é feita utilizando-se o modelo de avaliação proposto por Matheson \& Matheson (1998). Este modelo oferece uma seqüência de fatores que devem ser questionados e avaliados pelo pesquisador. Em função do resultado das entrevistas, o pesquisador atribuiu a cada fator um valor entre 1 (um) e 7 (sete), onde o um significa que o fator é praticamente ignorado na empresa e o sete significa que a empresa atingiu um desempenho tão alto naquele fator, que ainda que fosse possível melhorá-lo, isso não seria recompensador. Essa forma de medir é arbitrária e não exata, mas conforme comentário de Matheson \& Matheson (1998) ela é útil para se identificar e entender as forças e as fraquezas atuantes no processo de decisão.

Com o valor atribuído a cada fator é possível construir um diagrama tipo aranha, que facilita a análise da qualidade de decisão na empresa e possibilita a comparação entre duas ou mais empresas. A figura 3.4 apresenta um exemplo de um diagrama tipo aranha para duas empresas fictícias, onde a escala de um a sete foi transformada em porcentagem. 


\section{Figura 3.4 Diagrama tipo aranha}

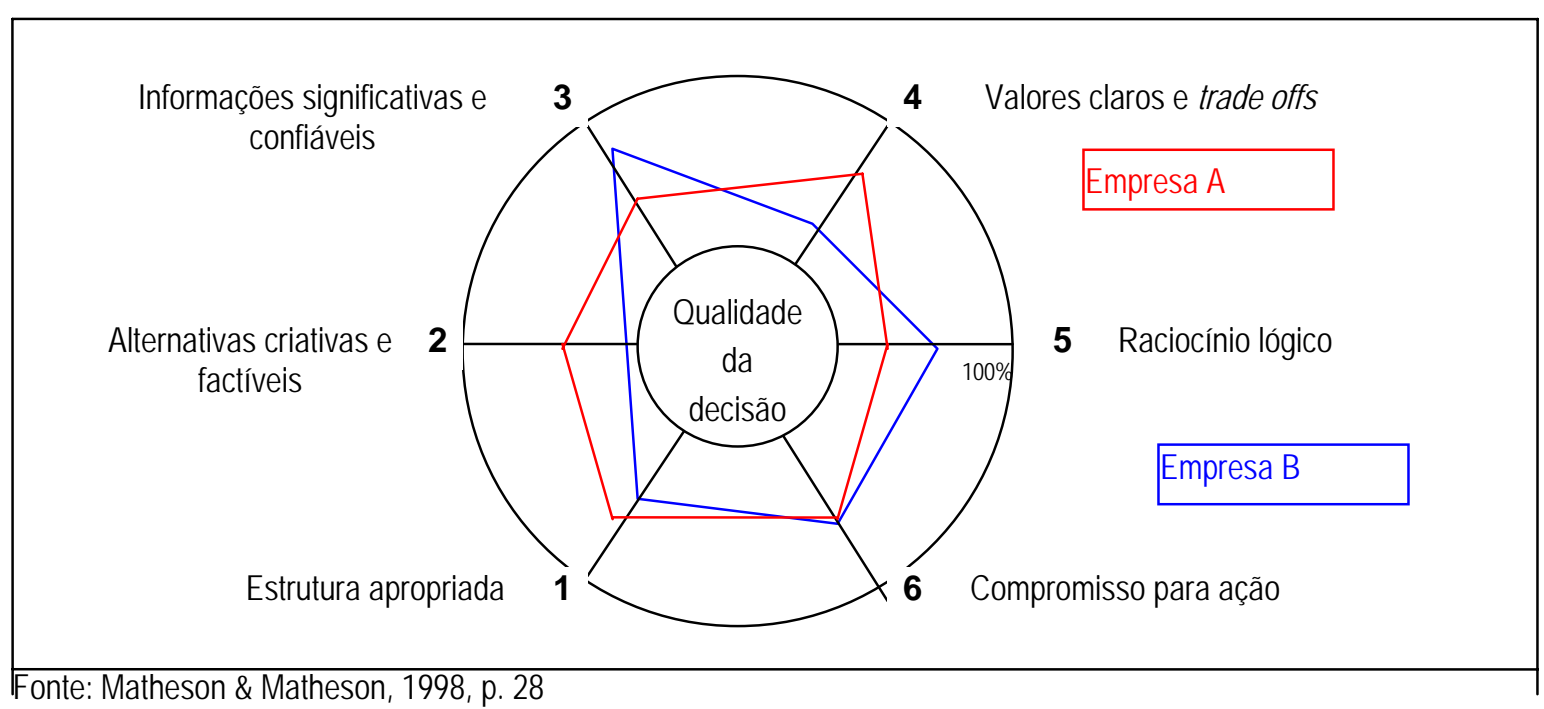

O contexto no qual a empresa se insere é analisado sob o ponto de vista das informações teóricas obtidas na bibliografia pertinente e das informações extraídas durante a entrevista. Neste caso, entende-se como contexto os aspectos econômicos que envolvem os negócios da empresa. Não se considera os outros aspectos, tais como sociais, culturais e outros. Esta consideração se deve ao fato de ter sido adotada a premissa de que apenas os aspectos econômicos influenciam a organização quanto à questão da tomada de decisão, enquanto os outros aspectos atuam diretamente sobre os indivíduos, que por sua vez influenciam a decisão através da percepção e tolerância ao risco.

A percepção ao risco é avaliada a partir de um teste padrão, aplicado aos entrevistados. Este teste não fornece valores absolutos da medição, mas serve para uma análise da percepção do risco dos decisores. A preocupação com um modelo padrão de teste para as cinco empresas se justifica em função da observação de Slovic, Fischhoff \& Lichtenstein (1982), de que o formato da apresentação de uma situação de risco tem grande impacto na percepção e comportamento das pessoas.

A tolerância ao risco das empresas é avaliada através da aplicação de um teste padrão, conforme o modelo proposto por Clemen (1996).

A relação das questões de pesquisa e da proposição do estudo com a teoria, bem como a forma como se desenvolveu a pesquisa e sua análise, são resumidas no quadro 3.1. 


\section{Quadro 3.1 Resumo das questões de pesquisa e proposição do estudo}

\begin{tabular}{|c|c|c|}
\hline \multicolumn{3}{|c|}{ Questão (1): Por que é tomada a decisão estratégica de desenvolver um novo produto? } \\
\hline EVIDÊNCIA TEÓRICA & PESQUISA & ANÁLISE \\
\hline $\begin{array}{l}\text { - Segundo Tidd, Bessant \& Pavitt (1997), a } \\
\text { maior parte das inovações resultam da } \\
\text { interação de diversas forças. } \\
\text { - Para Clark \& Wheelwright (1993), existem } \\
\text { três fatores críticos impulsionando a } \\
\text { inovação: intensa competição internacional, } \\
\text { demanda por produtos mais sofisticados e } \\
\text { rápidas mudanças de tecnologias. } \\
\text { - Para Baron (1994), a racionalidade da } \\
\text { decisão depende do método empregado e } \\
\text { independe do resultado. }\end{array}$ & $\begin{array}{l}\text { - Entrevistas semi- } \\
\text { estruturadas questionando os } \\
\text { dirigentes sobre as razõos } \\
\text { que os levaram a inovar. } \\
\text { • Verificação da racionalidade } \\
\text { da decisão. } \\
\text { - Verificação da proposição do } \\
\text { estudo, através de: a) teste } \\
\text { da percepção do risco; b) } \\
\text { teste da tolerância ao risco; c) } \\
\text { pesquisa da importância da } \\
\text { inovação. }\end{array}$ & $\begin{array}{l}\text { - Avaliação das respostas dos } \\
\text { entrevistados e a sua relação } \\
\text { com a teoria. } \\
\text { - Avaliação dos testes de } \\
\text { percepção e tolerância; } \\
\text { verificação do contexto das } \\
\text { empresas quanto à inovação e } \\
\text { comparação com a situação } \\
\text { teórica. } \\
\text { - Consistência da proposição. }\end{array}$ \\
\hline
\end{tabular}

\section{Questão (2): Como é tomada a decisão estratégica de desenvolver um novo produto?}

\begin{tabular}{|c|c|c|}
\hline EVIDÊNCIA TEÓRICA & PESQUISA & ANÁLISE \\
\hline $\begin{array}{l}\text { - Kruglianskas (1996) e Tidd \& Bessant \& } \\
\text { Pavitt (1997) estabelecem diversas } \\
\text { características do processo de inovação } \\
\text { na pequena empresa. } \\
\text { - De acordo com Matheson \& Matheson } \\
\text { (1998) a qualidade da decisão racional } \\
\text { pode ser avaliada através da medição } \\
\text { das seis dimensões. } \\
\text { - Segundo Pickle \& Abrahamson (1990) a } \\
\text { habilidade na tomada de decisão é uma } \\
\text { característica fundamental para o } \\
\text { empreendedor. }\end{array}$ & $\begin{array}{l}\text { - Entrevista semi-estruturada } \\
\text { abordando uma decisão } \\
\text { estratégica recente sobre } \\
\text { inovação para coleta de dados } \\
\text { referentes ao processo de } \\
\text { tomada de decisão. }\end{array}$ & $\begin{array}{l}\text { - Através dos dados obtidos nas } \\
\text { entrevistas estabelecer a } \\
\text { forma como se dá a tomada de } \\
\text { decisão e o nível de qualidade. }\end{array}$ \\
\hline
\end{tabular}




\subsection{Protocolo de pesquisa}

Neste item abordou-se o planejamento do estudo, estabelecendo as etapas, instrumentos, procedimentos e considerações gerais para realização da pesquisa.

\subsubsection{Etapas do estudo}

As etapas são:

a) Estudo de caso piloto

a.1) Entrevista preliminar

Apresentação do propósito da pesquisa e verificação do enquadramento da empresa nas condições definidas.

a.2) Coleta de dados, questionário

Coleta das informações gerais das diversas áreas da empresa.

a.3) Entrevista semi-estruturada

Segundo um roteiro prévio para obtenção das informações sobre o processo de inovação e a tomada de decisão.

a.4) Teste de percepção do risco

Conforme padrão previamente definido.

a.5) Teste de tolerância ao risco

Conforme padrão previamente definido.

a.6) Análise preliminar dos dados

Verificação se foram coletados todos os dados planejados.

a.7) Confirmação do resultado

Eventual, para a situação em que surge dados contraditórios.

b) Ajuste da pesquisa em função do resultado anterior

c) Estudo dos casos I, II, III e IV (com as etapas intermediárias eqüivalentes)

d) Análise final dos dados

e) Conclusão e redação final 


\subsubsection{Procedimentos}

A entrevista preliminar é o primeiro contato formal entre o pesquisador e a empresa. Nesta ocasião são realizadas as seguintes tarefas:

1) Exposição do conteúdo da pesquisa e de seus objetivos ao principal administrador da empresa, preferencialmente o seu proprietário.

2) Compromisso de sigilo das informações consideradas confidenciais. Definição de quais informações podem constar da pesquisa.

3) Coleta das informações preliminares da empresa, ou seja:

a) Razão social e composição acionária;

b) Endereço, telefone, contato;

c) Atividade da empresa;

d) Número de empregados;

e) Forma da organização (organograma);

f) Data de fundação e principais fases de expansão;

g) Comentários gerais sobre a empresa e o negócio;

h) Ordem de grandeza do faturamento de 1998.

4) Planejamento do desenvolvimento da pesquisa, definindo as pessoas envolvidas com o processo de inovação que serão entrevistadas e as possíveis datas.

5) Programar a coleta de dados e eventuais visitas às áreas de produção, recursos humanos, marketing e finanças.

A entrevista semi-estruturada tem como principal objetivo coletar dados sobre: a) visão da empresa sobre a importância da inovação; b) por que foi decidido inovar c) como foi tomada a decisão de inovar; d) qualidade da decisão estratégica.

Devem ser entrevistados os administradores que participam diretamente da decisão estratégica de desenvolver um novo produto e/ou processo e que são responsáveis pela implementação da decisão, com prioridade para os diretores e/ou proprietário(s) da empresa.

Esta entrevista está dividida em duas partes:

a) Processo de inovação

b) Tomada de decisão

Para cada parte existe um conjunto de questões que deve fornecer os dados necessários para a análise posterior.

O teste de percepção do risco foi aplicado aos diretores e gerentes da empresa que estavam diretamente envolvidos com as decisões estratégicas do processo de inovação. De acordo com a estrutura das decisões estratégicas da empresa definiu-se o número de 
pessoas aos quais se aplicou o teste. Caso as decisões fossem fortemente centralizadas em um diretor, o teste seria aplicado somente nele. Por outro lado, se vários diretores participassem do processo decisório, procurar-se-ia aplicar o teste em todos.

Este teste visa o estabelecimento do grau de percepção do risco da empresa para uma determinada situação que envolva o desenvolvimento de um novo produto e/ou processo.

O teste de tolerância ao risco foi aplicado às mesmas pessoas que participaram do teste de percepção. O objetivo do teste é obter a tolerância ao risco da empresa.

O teste versa sobre uma decisão de investir ou não em um projeto sob determinadas condições, para determinação do parâmetro $\mathrm{R}$, a tolerância ao risco. É importante que a mesma estrutura do problema, sobre o qual tem que se tomar uma decisão, permaneça inalterada para os cinco casos.

A análise preliminar dos dados foi feita após as entrevistas e testes, com a finalidade de registrar os principais resultados em um relatório.

Com o encerramento da pesquisa realizada na empresa piloto foi possível realizar os ajustes necessários no planejamento para realizar a pesquisa na empresa seguinte.

A análise final dos dados levou em conta os detalhes de cada caso, procurando determinar as semelhanças e diferenças entre eles.

\subsubsection{Instrumentos de pesquisa}

Os instrumentos de pesquisa apresentados no capítulo 7, anexos, são:
a) Roteiro para entrevista preliminar
b) Questionário - Informações Gerais
c) Roteiro para entrevista - Inovação
d) Roteiro para entrevista - tomada de decisão
e) Roteiro para aplicação do teste de percepção do risco
f) Roteiro para aplicação do teste de tolerância ao risco 


\section{CAPÍTULO 4}

\section{APRESENTAÇÃO DOS RESULTADOS}

Foi omitida a razão social das empresas estudadas, em respeito ao compromisso assumido previamente entre o pesquisador e os entrevistados.

As cinco empresas foram denominadas A, B, C, D e E.

Quatro das cinco empresas escolhidas atendem às três condições estabelecidas neste estudo para que sejam enquadradas como pequenas empresas, ou seja:

1) O diretor presidente da empresa participa diretamente das decisões estratégicas sobre desenvolvimento de produtos;

2) O faturamento em 1998 foi inferior a $R \$ 10$ milhões;

3) Possuir menos de cem funcionários.

Apenas a empresa $\mathbf{E}$ atende duas das três condições estabelecidas, ou seja, o proprietário e diretor presidente da empresa participa diretamente das decisões estratégicas sobre desenvolvimento de produtos e possui menos de cem funcionários. $O$ faturamento em 1998 não foi inferior a R\$ 10 milhões, mas de acordo com o critério estabelecido neste estudo, basta que duas condições sejam atendidas, desde que uma delas seja a forma de tomar decisão. Nesse sentido, a empresa E apesar de ter um faturamento superior a $\mathrm{R} \$ 10$ milhões, foi considerada uma pequena empresa.

A empresa A por ser um caso piloto foi estudada em maior profundidade, servindo para aperfeiçoar os instrumentos de pesquisa e sintetizar a apresentação do resultado dos outros casos.

\subsection{Caso piloto (empresa A)}

Para coletar os dados da empresa piloto foram realizadas diversas visitas à sua fábrica e entrevistados três diretores e três gerentes.

A empresa A é uma pequena indústria que produz e comercializa biocidas; instalada numa pequena cidade do interior do estado de São Paulo, possui apenas 20 funcionários distribuídos em três níveis hierárquicos. Seu faturamento anual tem crescido constantemente ao longo dos últimos dez anos, foi de $\mathrm{R} \$ 4,8$ milhões em 1998, com estimativa de $\mathrm{R} \$ 7$ milhões para 1999. Seus principais clientes são os fabricantes de tintas, 
empresas de grande porte e multinacionais. O seu processo de produção é bastante simples, em bateladas, constando basicamente de um reator para formulação e preparação dos biocidas, sistemas auxiliares e de controle de operação. A sua capacidade instalada é de aproximadamente 80 t/mês. As matérias-primas são na maior parte importadas.

A empresa A possui dois laboratórios: um de microbiologia, onde são desenvolvidas as colônias de microorganismos e realizados os diversos testes de eficiência das amostras e outro para controle da qualidade e desenvolvimento de novos produtos. Utiliza-se de acordos com a UNICAMP (Universidade de Campinas) para desenvolvimento da tecnologia. Para atender à crescente demanda do mercado, a empresa A está investindo na ampliação da sua instalação produtiva e dos laboratórios.

Hoje, após dez anos de existência, a empresa A é conhecida e respeitada no setor de biocidas para o mercado de tintas e começa a entrar em outros mercados.

A sua linha de produtos, que há dez anos era composta de dois produtos, específicos para aplicação exclusivamente no mercado de tintas_que continua sendo o seu principal mercado _ conta hoje com vinte e nove diferentes produtos para aplicação em diversos mercados. Há um ano e meio desenvolveu novos produtos para atender os mercados de couro, lubrificantes, papel, cola, produtos têxteis, plásticos e tratamento de água. Nos dois últimos anos, foram lançados dez produtos, novos que são hoje responsáveis por aproximadamente $25 \%$ do faturamento da empresa.

A empresa A gasta aproximadamente 1,5\% do faturamento com P\&D e 1,0\% com treinamento. A mão-de-obra representa $12 \%$ do custo total.

\subsubsection{A história da empresa A}

Até o início da década de 80, as indústrias brasileiras ainda utilizavam a estratégia de crescer através da verticalização das suas atividades. Em meados desta década, a verticalização foi duramente combatida e em seu lugar surgiu a estratégia de crescimento com concentração das atividades no negócio central da empresa. Terceirização, reengenharia, benchmarking, controle de custos e os programas de qualidade contribuíram para esta nova tendência.

A indústria de tintas, assim como tantas outras, passou por essa mudança e ainda hoje procura transferir algumas atividades, consideradas secundárias para o seu negócio, para outras empresas. Se é verdade que o resultado dessa nova estratégia tornou a indústria de tintas mais eficiente e competitiva, por outro lado, essas indústrias perderam a capacidade de resolver alguns problemas operacionais por conta própria, passando a depender da tecnologia e serviços de terceiros. Nessas circunstâncias, novos parceiros qualificados e especializados tornaram-se altamente desejáveis. 
O fundador e sócio majoritário da empresa A, um técnico químico de formação, possuía uma grande vivência profissional no setor de tintas, onde havia atuado durante vários anos. Com o seu conhecimento e espírito empreendedor percebeu que as restrições aos biocidas de base mercurial com alta toxidez, até então utilizados pela indústria de tintas brasileira, representavam uma excelente oportunidade para aplicação dos seus conhecimentos em um novo negócio; nascia, assim, a empresa $\mathbf{A}$.

A empresa A surgiu em 1988, produzindo biocidas de baixa toxidez, inicialmente com a produção sendo realizada por terceiros e posteriormente na sua fábrica localizada no estado de São Paulo, onde está até hoje.

O surgimento da empresa A foi marcado, portanto, pelo desafio de desenvolver um novo biocida para o mercado brasileiro de tintas que fosse menos tóxico. Por volta de 1987, a pressão dos ambientalistas para aumentar a proteção ao meio ambiente resultou na aprovação de uma legislação proibindo o uso de biocidas à base de mercúrio, que possuem uma alta eficiência no combate aos microorganismos, mas por outro lado, são altamente tóxicos. Com a nova legislação, a indústria brasileira de tintas precisava, em pouco tempo, substituir os biocidas em uso por outro menos tóxico e se possível, com a mesma eficiência e custo.

Algumas empresas multinacionais já produziam no exterior biocidas de baixa toxidez e alta eficiência, mas com um preço elevado. Essas multinacionais, em geral, são produtoras de uma molécula, como a isotiazolona e comercializam apenas biocidas baseados na sua molécula, em diferentes concentrações. O fundador da empresa A percebeu que existia uma oportunidade para colocar em prática os conhecimentos acumulados durante o tempo que atuou na indústria de tintas e desenvolveu dois produtos, um fungicida e um bactericida, formulados a partir da molécula comercializada pelas multinacionais com uma base sintetizada por ele. Estes dois novos produtos foram testados e aprovados pela indústria de tintas, tornando-se em poucos meses a primeira linha de produtos para sustentação da empresa A. Os novos biocidas custavam US\$15/Kg contra US\$ 35/Kg dos fornecidos pelas multinacionais; possuíam melhor estabilidade e eram tão eficientes quanto aqueles ou melhores e com o mesmo nível de toxidez.

A primeira grande dúvida da empresa foi estabelecer uma estratégia para a sua atuação. Havia duas alternativas para desenvolver a linha de produtos e como conseqüência o seu próprio perfil de empresa: 1) adotar uma linha diversificada de produtos, na área de especialidades químicas, tais como biocidas, anti-espumantes, dispersantes e outros, para atender prioritariamente o mercado de tintas; 2) concentrar-se na produção de biocidas e apesar de ter como alvo inicial o mercado de tintas, no futuro, procurar penetrar em outros mercados. 
A alternativa escolhida foi a segunda, permitindo que a empresa encontrasse o seu nicho de mercado como especialista em microbiologia voltada para o mercado de tintas e com reais possibilidades de penetrar em outros mercados. Esta característica da empresa $\mathbf{A}$ a diferencia de seus concorrentes de pequeno porte que, em geral, adotam a estratégia de se diversificarem como produtores de especialidades químicas.

Uma vez definido o caminho de especialista em microbiologia, a empresa $\mathbf{A}$ estabeleceu uma estratégia simples e eficiente para crescer e se tornar competitiva. Conquistar o mercado de biocidas para tintas inicialmente e depois penetrar em outros mercados com base na excelência em três aspectos fundamentais: conhecimento e capacitação tecnológica, qualidade e inovação.

O conhecimento e capacitação tecnológica para atender o mercado de biocidas nasceram com a experiência do seu fundador e foram constantemente ampliados através da contratação de técnicos e de diversos investimentos feitos neste sentido.

A consulta e troca de informações com Institutos de Pesquisa, Universidades e publicações especializadas ajudaram a consolidar uma equipe com profundos conhecimentos de microbiologia. Outra fonte importante para o desenvolvimento tecnológico da empresa $\mathbf{A}$ foi um acordo assinado com uma multinacional inglesa, que produz moléculas para biocidas.

\subsubsection{O mercado da empresa A}

O biocida é uma substância que impede ou inibe o crescimento de microorganismos, como os fungos, bactérias e algas, em diferentes situações e para diferentes produtos, desde a etapa de produção até a sua aplicação final.

Os biocidas evitam problemas causados por microorganismos como o crescimento de biofilme em processos de fabricação de papel e em sistemas de refrigeração; preservam tintas, polímeros e adesivos em emulsão; evitam as perdas no processamento industrial de couros, aumentam o tempo de uso de colas naturais; protegem óleos de corte e lubrificantes; evitam a deterioração de plásticos e a descoloração e destruição da madeira; estão presentes nos desinfetantes para ambientes hospitalares, industriais e residenciais; protegem produtos alimentícios, veterinários e cosméticos. O vasto campo de aplicação dos biocidas não se encerra nos exemplos citados acima e a cada dia novos materiais surgem, requerendo a proteção contra a deterioração microbiana.

Os benefícios diretos da utilização de um biocida eficiente para um produto genérico sujeito às ações dos microorganismos podem ser resumidos, em geral, na maior vida útil do produto, contribuindo, assim, para a redução de desperdícios e aumento do valor intrínseco do produto. Outro papel importante do biocida é a sua ação em sistemas aquosos dos processos de produção. A inibição do crescimento de microorganismos nestes sistemas 
permite o prolongamento do período produtivo sem interrupção para manutenção, reduzindo, desta forma, as perdas advindas da parada da linha. Na produção de papel, por exemplo, a interrupção da linha de produção durante algumas horas provoca a perda de centenas de milhares de reais, se computado somente o lucro cessante.

Hoje, a tendência mundial no mercado de biocidas é para a busca de produtos com maior eficiência no combate aos microorganismos e que tenha ao mesmo tempo a menor toxicidade possível. Maior eficiência significa que o biocida tenha alto poder de combate e também capacidade de atacar diferentes microorganismos, isto é, possuir um largo espectro de ação.

O mercado de biocidas movimenta quantidades de materiais relativamente pequenas e aparentemente é mais sensível à qualidade do produto, principalmente nos quesitos eficiência e toxicidade, do que a preços. Essas características são típicas dos produtos classificados como especialidades químicas. Em alguns casos, o biocida chega a ser desenvolvido especificamente para um determinado cliente e/ou produto, tornando-se um biocida "taylor made".

A tabela 4.1 apresenta uma estimativa do mercado brasileiro de biocidas, considerando apenas algumas das principais aplicações. 


\section{Tabela 4.1 - Estimativa do mercado de biocidas para 1998}

\begin{tabular}{|lc|}
\hline SEGMENTO & $\begin{array}{c}\text { DEMANDA DO MERCADO } \\
\text { (TON/ANO) }\end{array}$ \\
Tinta & 2.200 \\
Emulsão e adesivo & 1.000 \\
Couro & 1.200 \\
Químico & 300 \\
Produtos domésticos & 2.700 \\
Tratamento de água & 850 \\
Fluidos para trabalho em metais & 350 \\
Papel & 1.580 \\
Cosméticos & 400 \\
Têxtil & 300 \\
Diversos & 500 \\
Total & 11.380 \\
\hline
\end{tabular}

\subsection{3 $A$ administração da inovação na empresa $A$}

Nos primeiros anos de existência da empresa A, foram desenvolvidos, em média, dois produtos novos por ano, passando depois a três. Nos dois últimos anos, a empresa atingiu o número de quatro novos produtos por ano.

O mesmo processo de desenvolvimento realizado nos primeiros produtos tem se repetido com pequenas alterações, atingindo um alto índice de sucesso. Em média, a empresa A gasta aproximadamente oito meses para desenvolver um novo produto, considerando-se como marco inicial a decisão de desenvolvê-lo e, como final, o lançamento de seu primeiro lote comercial.

A Figura 4.1, expõe graficamente as principais etapas do processo de desenvolvimento de produtos adotado pela empresa $\mathbf{A}$. 
Figura 4.1 - Processo de desenvolvimento de produtos - empresa A

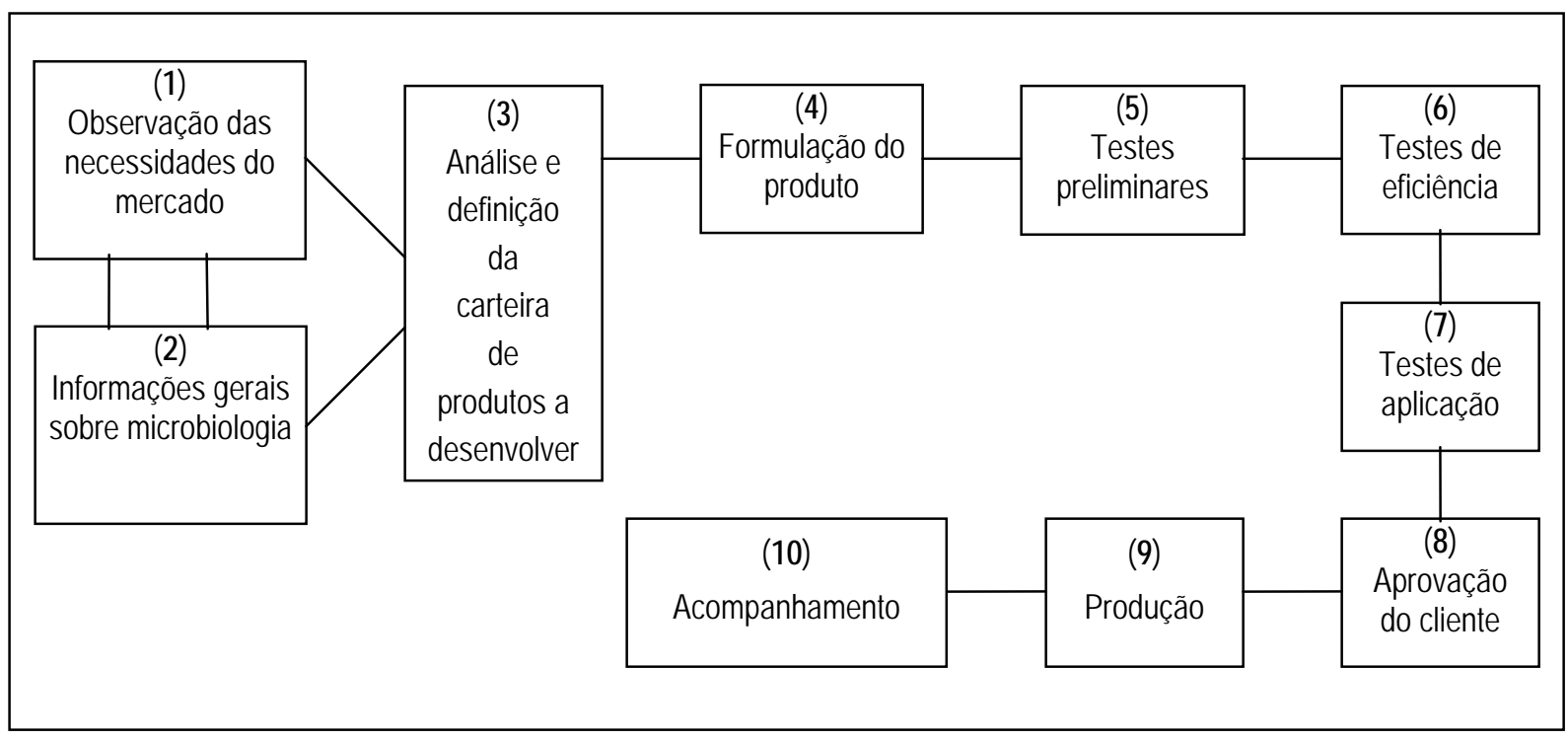

\section{Etapa (1) - Observação das necessidades do mercado}

O contato com o cliente e a observação das suas necessidades têm sido a grande fonte de alimentação do processo de desenvolvimento de novos produtos. O sucesso desta etapa depende, em tese, do desempenho das pessoas que mantêm o contato com clientes, em geral, pertencentes à equipe de Marketing e de Assistência técnica. Conhecimento, experiência e percepção dos problemas são pré-requisitos fundamentais para realizar esta difícil e importante tarefa. Muitas vezes, o próprio cliente não conhece o seu problema e o que pode ser ainda mais crítico, nem percebe em tempo que o problema existe.

A ação de um biocida, propiciando o prolongamento da vida útil de um produto embalado e na prateleira, determina, em última análise, a validade do produto. Isto pode não estar sendo percebido pelo fabricante como um benefício e como solução de alguns problemas, cabendo ao especialista alertá-lo sobre esta questão. Outras vezes, o fabricante percebe que precisa melhorar a performance do produto quanto à inibição de microorganismos e até deseja adicionar um biocida ao produto, mas desconhece como, onde e em que quantidade fazê-lo.

A empresa A realiza esta interação com os clientes, através não só da sua equipe de marketing e assistência técnica, mas também com seu pessoal de produção e desenvolvimento de produtos. 


\section{Etapa (2) - Informações gerais sobre microbiologia}

O acervo de conhecimentos já adquiridos e a sua ampliação através dos constantes contatos com alguns dos principais geradores de conhecimentos em microbiologia tem contribuído para a criação de novos produtos além de propiciarem uma assistência técnica mais eficiente. Para se manter atualizada, a empresa incentiva o treinamento e a participação de seus técnicos em eventos sobre microbiologia.

Recentemente, a literatura especializada noticiou o desenvolvimento, no exterior, de um novo biocida que reunia as ações de fungicida e algicida em um só produto. Esta informação foi analisada na empresa A e considerada de grande interesse para aplicação no mercado brasileiro, dado os benefícios que resultam para o cliente na aplicação de apenas um produto ao invés de dois. A empresa $\mathbf{A}$ investiu no desenvolvimento desse novo biocida, baseada apenas nessa informação e em sua experiência, sem que houvesse qualquer demanda do mercado, e hoje é a única empresa brasileira que possui um biocida com dupla ação. Certamente, o pioneirismo no lançamento deste novo produto no mercado deverá representar uma grande vantagem competitiva.

\section{Etapa (3) - Análise e definição da carteira de desenvolvimentos}

A empresa A tem mantido uma carteira de dois a três novos produtos em desenvolvimento, considerando os vários estágios do processo.

A análise das propostas e a tomada de decisão sobre quais produtos serão desenvolvidos é feita pela direção da empresa com a participação da equipe técnica/comercial. Não existe um procedimento formal, não se realiza pesquisa de mercado e nem são utilizados softwares para esta análise e decisão. O porte da empresa e os resultados obtidos têm, segundo seus administradores, justificado a ausência de maior sofisticação nesta etapa do processo.

\section{Etapas (4) I (5) - Formulação do produto / Testes preliminares}

Esta é a "caixa preta" do processo de desenvolvimento de novos produtos. Nesta etapa concentra-se o "know how" da empresa. Uma vez definida uma formulação é feito um pequeno lote em laboratório para realização dos primeiros testes. Esses testes servem apenas para definir algumas características básicas do produto que subsidiam uma primeira avaliação. 
A rapidez e o baixo custo dessas etapas são fundamentais para o sucesso de todo o processo. Em geral, a decisão de aplicar os recursos no desenvolvimento de um novo produto são tomadas em função do resultado dessas duas etapas.

\section{Etapas (6) / (7) - Teste de eficiência / Testes de aplicação}

Estes testes praticamente definem a aprovação ou não do produto como um biocida. Os testes de eficiência são realizados no laboratório de microbiologia da empresa $\mathbf{A}$, enquanto os testes de aplicação são realizados parcialmente em laboratório e também nas condições reais de aplicação do produto, nas instalações do cliente. O biocida deve exercer o seu papel de inibição do crescimento de microorganismos sem afetar negativamente as propriedades esperadas para o produto ao qual foi incorporado. Em se tratando de tintas não deve alterar propriedades como cor, brilho, odor e outras.

Quando, durante os testes de aplicação, o produto apresentar algum problema, a análise indicará se há a possibilidade de realizar ajustes na formulação e repetir a bateria de testes, ou, em outra hipótese, se o desenvolvimento deverá ser abortado.

\section{Etapas (8) I (9) e (10) - Aprovação / Produção / Acompanhamento}

A aprovação final do produto é feita pelo cliente após todos os testes. Uma vez aprovado, o produto entrará em fase de produção comercial, sendo preparado um lote para venda. O processamento do primeiro lote do produto ao qual o biocida estiver sendo adicionado, será acompanhado desde o início do processo até a fase final de embalagem. Este acompanhamento tem um caráter de assistência técnica ao cliente, evitando que ocorra alguma distorção na aplicação do biocida ao mesmo tempo que fornece informações importantes para a empresa $\mathbf{A}$.

\subsubsection{A inovação em serviços}

Quando um cliente compra um biocida da empresa A está na verdade comprando um pacote de serviços técnicos. Junto com o produto é oferecido uma grande variedade de serviços. A empresa A percebeu, logo no início de suas atividades, que a maior parte de seus clientes recorria ao biocida para proteger o produto apenas na fase final do processo mas não estava familiarizada com os cuidados necessários para evitar a propagação dos microorganismos nas etapas anteriores do processo. Para facilitar a penetração do seu produto e ao mesmo tempo aumentar a eficiência do combate aos microorganismos, a empresa A passou a oferecer um suporte técnico completo para estabelecer o melhor procedimento de esterilização, assepsia e higienização de fábricas. O suporte técnico é composto de diagnóstico dos pontos críticos através de análise de amostras coletadas, propostas de controle de higienização e esterilização, monitoramento do sistema e treinamento da equipe operacional. 
Criatividade e inovação, são duas idéias arraigadas nesta pequena empresa, não só no desenvolvimento de novos produtos, mas também na sensibilização do mercado e na prestação de serviços. Duas soluções encontradas pela empresa A para suas questões operacionais ilustram esta afirmativa:

kit de teste - existe uma grande diversidade de porte e de capacidade técnica entre os fabricantes de tintas, que vai desde as empresas multinacionais (com várias unidades de produção espalhadas pelo território brasileiro) às microempresas. A qualidade das tintas também varia conforme a aplicação e fabricante. Uma parcela considerável do mercado de biocidas para tintas está nas mãos de pequenos fabricantes, com pouco ou nenhum conhecimento da ação dos microorganismos.

A questão a ser resolvida para poder fornecer biocidas aos fabricantes de tintas era: como sensibilizar estes pequenos fabricantes de tintas quanto à ação dos biocidas?

Para vencer este obstáculo, a empresa A criou um kit de teste, simples e muito eficaz. O kit é composto apenas de dois pequenos tubos plásticos transparentes. O cliente assistido por um técnico da empresa A, coleta duas amostras de seu próprio produto (tinta), acondicionando-as nos dois tubos: no primeiro, sem nenhuma proteção, enquanto que, no segundo, adicionada do biocida. Os dois tubos ficam no escritório do cliente. Após algumas semanas, o cliente tem à sua frente a diferença entre uma tinta protegida por um biocida e aquela que está sendo produzida e vendida. A deterioração da tinta sem proteção é visível e impossível de não ser notada.

O kit foi um enorme sucesso, e continua a ser usado como ferramenta de teste para diversos produtos além de tintas, ainda que agora já tenha sido copiado pelos concorrentes.

Contêiner duplo - o outro exemplo interessante de inovação desenvolvida pela empresa A na área de serviços foi um contêiner duplo. Inicialmente projetado para solucionar um problema do cliente, acabou por gerar uma vantagem competitiva para a empresa.

Os biocidas são considerados produtos agressivos ao meio ambiente e portanto devem receber no seu manuseio e transporte os cuidados recomendados pelas normas de segurança, inclusive previstas na legislação de proteção ao meio ambiente. Devem ser previstos sistemas de retenção e coleta dos possíveis vazamentos, sempre que houver manuseio do produto, para evitar impactos ambientais.

O biocida é uma substancia líquida, fornecida aos clientes em recipientes plásticos de 50, 100 ou 200 litros. Para os pequenos e médios clientes estes recipientes estão perfeitamente adequados; por serem volumes pequenos, o manuseio e a estocagem são procedimentos fáceis e seguros. 
Para fornecer aos grandes fabricantes de tintas, a empresa A desenvolveu um contêiner metálico com capacidade de 1000 litros e com algumas características especiais: o próprio contêiner já incorpora um tanque de retenção, podendo assim ser manuseado pelo cliente em qualquer área da fábrica sem a necessidade de ficar restrito a uma única instalação protegida com diques de retenção. Outra característica do contêiner é possibilitar mais segurança na operação de transferência do biocida para a unidade de produção do cliente. É praticamente impossível a ocorrência de erros operacionais na abertura de válvulas, pois existe um sistema que impede este tipo de acidente.

Este novo contêiner trouxe diversas vantagens para o cliente _ menos manuseio de recipientes e como conseqüência mais segurança; maior flexibilidade para instalar o sistema de transferência e o contêiner em qualquer área; dispensa o investimento em sistemas de contenção; na hipótese de que ocorra algum problema o produto pode ser aproveitado a partir do tanque de retenção. Esses contêiners estão sendo patenteados e são fornecidos aos clientes sem qualquer ônus adicional.

Para a empresa A, o fornecimento em contêiners, apesar do investimento na fabricação, traz também algumas vantagens interessantes: cria um cliente cativo; aumenta a segurança no transporte; elimina o custo das embalagens plásticas.

O quadro 4.1 apresenta um resumo dos principais dados referentes ao processo de inovação na empresa A, conforme a declaração dos entrevistados, isto é, de acordo com o ponto de vista da empresa.

\section{Quadro 4.1 Resumo dos dados sobre inovação - empresa A}

1) Objetivo maior da empresa

- Crescer atingindo novos mercados, atender bem os clientes.

2) Relação das inovações com objetivo

- Novos mercados exigem novos produtos.

3) Importância dos novos produtos

- Alta, manter crescimento. 
4) Posição da empresa em relação aos concorrentes

- Entre inovadora e muito inovadora.

5) Visão sobre o setor que atua

- O setor ainda é pouco inovador, neutro. Nota-se uma mudança no sentido de se tornar inovador.

6) Por que decidiu inovar

a) Percebeu a oportunidade; filosofia desde o início.

a1) Para poder crescer; para melhorar.

a2) É fundamental para a empresa; o mercado é dinâmico.

b) O que fez a empresa tomar essa decisão

- Pedido do mercado; observação do mercado; estratégia da empresa.

c) Maiores dificuldades

- Recursos humanos capacitados.

d) Benefícios para a empresa

- Crescimento, participação no mercado, imagem no mercado, confiança no desenvolvimento.

\subsubsection{A tomada de decisão na empresa A}

A decisão em desenvolvimento de novos produtos na empresa A é tomada, em geral, com a participação de seis pessoas: Diretor presidente, Diretor administrativo financeiro, Diretor de marketing, Gerente de marketing e dois gerentes de desenvolvimento de produto/assistência técnica. Nesta empresa, as inovações estão principalmente relacionadas ao desenvolvimento de novos produtos, ficando o desenvolvimento do processo produtivo em segundo plano.

\section{A decisão estudada}

Para análise da tomada de decisão e por sugestão dos entrevistados, foi considerada a decisão do desenvolvimento de um biocida chamado de multi-uso, que incorpora a ação fungicida e algicida, realizado há aproximadamente doze meses.

Recentemente, a literatura especializada noticiou o desenvolvimento no exterior, de um novo biocida que reunia as ações de fungicida e algicida em um só produto. Esta informação foi analisada na empresa A e considerada de grande interesse para aplicação 
no mercado brasileiro, dado os benefícios que resultam para o cliente na aplicação de apenas um produto ao invés de dois; facilidade operacional, redução no custo de aplicação, redução do estoque, são algumas das vantagens observadas.

A empresa $\mathbf{A}$ investiu no desenvolvimento desse novo biocida, baseada apenas nessa informação e em sua experiência, sem que houvesse qualquer demanda do mercado e hoje é a única empresa brasileira que possui um biocida com dupla ação. Certamente, o pioneirismo no lançamento deste novo produto no mercado tem representado uma grande vantagem competitiva.

O fato que marcou a tomada de decisão, segundo os dirigentes da empresa, foi a visita e reunião com um cliente (empresa multinacional), onde se percebeu a vantagem de um único produto substituindo os dois existentes. Após essa visita, a empresa $\mathbf{A}$ desenvolveu uma nova formulação, que pode ser caracterizada como a primeira tentativa de desenvolver o novo produto, para teste em laboratório. Em função do resultado promissor do teste foi definido que a empresa A se empenharia no desenvolvimento deste novo produto.

Apesar do fato marcante da tomada de decisão, citado pelos entrevistados, ter sido a visita ao cliente, aparentemente, este fato está mais relacionado ao surgimento da idéia.

Devido as características do processo de desenvolvimento de produtos da empresa A, no qual é possível desenvolver e testar uma nova formulação em pouco tempo e com baixo custo, a decisão sobre o desenvolvimento de novos produtos, em geral, pode ser tomada após os testes preliminares do produto. Esta condição reduz sensivelmente o risco de desenvolvimento.

O quadro 4.2 apresenta a avaliação (do pesquisador) de uma decisão tomada pela empresa A, de acordo com o método proposto por Matheson \& Matheson (1998). Cada quesito foi avaliado com uma nota que pode variar de 1 a 7.

\section{Quadro 4.2 Qualidade da tomada de decisão - empresa A}

\section{Projeto de inovação escolhido}

- Desenvolvimento de um biocida multi-uso.

- Realizado há um ano.

Estrutura da decisão

- As principais áreas da empresa participam da decisão.

- Algumas questões geradas na análise do projeto.

- Riscos e benefícios parcialmente analisados.

- Avaliação: 6

\section{Alternativas}

- Levantadas seis alternativas.

- Aparentemente foi feita uma avaliação das alternativas.

- Não foi definido um plano formal para implementar a decisão. 


\section{Informações}

- Não foi feita avaliação da probabilidade de sucesso, técnico e de mercado.

- As principais informações foram coletadas.

- Não utilizou recursos externos.

- Avaliação: 5

Valores e trade offs

- Relação entre risco e retorno do projeto desconhecida.

- Desconhecido o impacto do projeto no fluxo de caixa.

- Não avaliado o custo da falha.

- Avaliação: 4

\section{Raciocínio lógico}

- Não utiliza métodos quantitativos.

- Aparentemente o projeto sofreu alterações.

- Avaliação: 4

Compromisso para ação

- Os responsáveis pela implementação participam da decisão.

- Não houve discordância quanto à decisão.

- Riscos e benefícios divulgados.

- Avaliação: 7 


\section{Figura 4.2 Diagrama tipo aranha - empresa A}

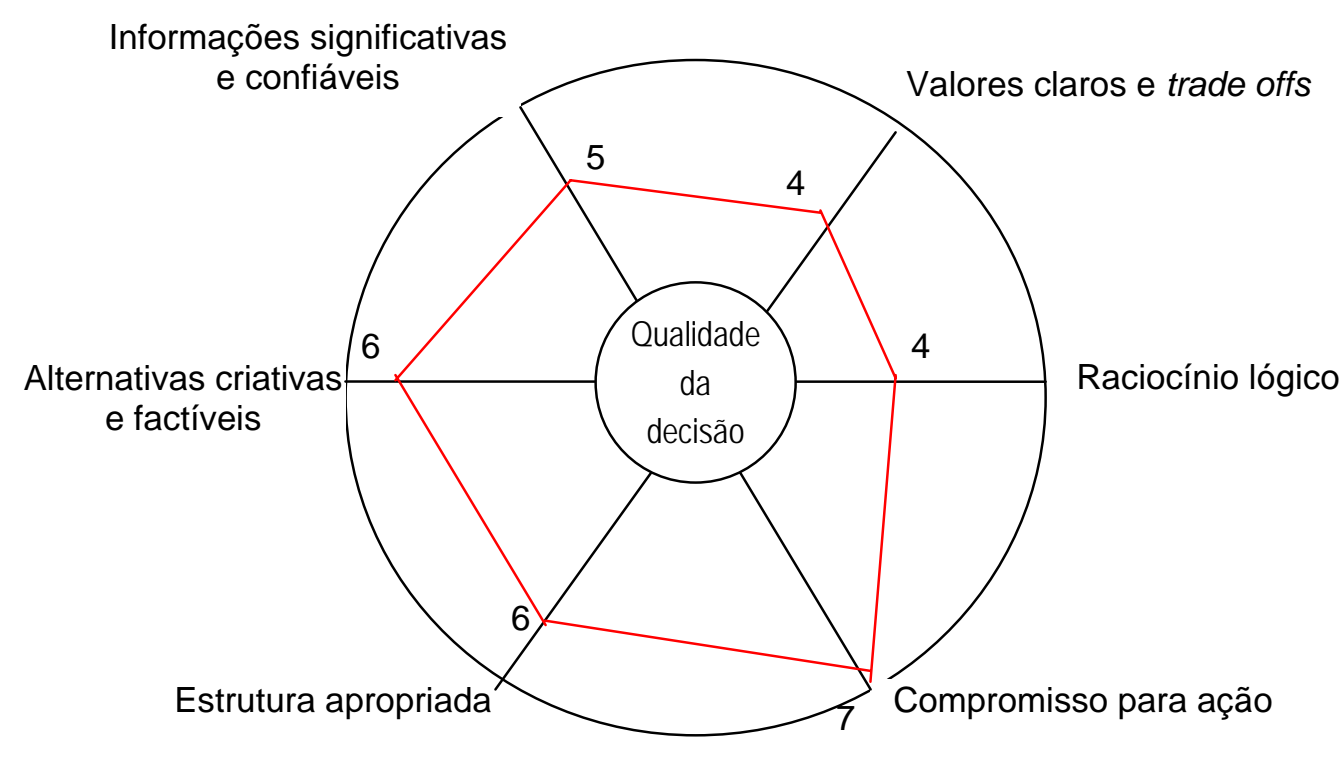

A figura 4.2 ilustra a qualidade da decisão tomada na empresa $\mathbf{A}$, onde se observa que os quesitos estrutura e alternativas atingiram um nível de $85 \%$ do máximo, podendo ser classificados como bons. Informações com $71 \%$ do máximo ainda pode ser considerado bom. Os quesitos valores e trade off e raciocínio lógico com 57\% demonstram que é possível melhorar significativamente a qualidade da decisão nestes dois aspectos. Finalmente, o quesito compromisso para ação atingiu o nível de 100\%, o que significa que não vale a pena a empresa A gastar energia para melhorá-lo. De maneira geral, pode-se considerar a qualidade de decisão na empresa $\mathbf{A}$ como adequada ao porte da empresa e ao processo de desenvolvimento de novos produtos. 


\subsubsection{Percepção e tolerância ao risco na empresa A}

Para avaliar a percepção e tolerância ao risco da empresa $\mathbf{A}$ foram aplicados os dois testes previstos na metodologia em três diretores e um gerente, que representam os principais decisores da empresa. Os resultados do teste de percepção do risco e tolerância ao risco são apresentados na tabela 4.2 e 4.3 , respectivamente.

Tabela 4.2 resultado do teste de percepção do risco - empresa A

\begin{tabular}{|c|c|}
\hline Participante & Probabilidade atribuída (\%) \\
\hline a (diretor-presidente) & 40 \\
\hline b & 30 \\
\hline c & 33 \\
\hline d & 60 \\
\hline Média & 40,8 \\
\hline
\end{tabular}

Tabela 4.3 Resultado do teste de tolerância ao risco - empresa A

\begin{tabular}{|c|c|c|}
\hline Participante & Tolerância (R em R\$) & Tolerância (\% das vendas) \\
\hline a & 425.000 & 7,2 \\
\hline b & 235.000 & 4,0 \\
\hline c & ND & ND \\
\hline d & 240.000 & 4,1 \\
\hline Média & 300.000 & 5,1 \\
\hline
\end{tabular}

A identificação dos decisores ( $a, b, c, d)$ foi mantida para os dois testes.

A notação ND significa que o decisor c não declarou um valor para o teste. Para cálculo da média foram considerados apenas os valores de três decisores.

Para cálculo da tolerância em \% das vendas foi considerado como o valor das vendas, a média dos faturamentos de 1998 e 1999, R\$ 5,9 milhões. 


\subsection{Caso I (empresa B)}

Para coletar os dados da empresa $\mathbf{B}$ foram realizadas duas entrevistas com o diretor presidente, uma entrevista com o gerente industrial e uma visita à fábrica.

A empresa B é uma indústria de pequeno porte que produz e comercializa formol e resinas de uréia formol, instalada na grande São Paulo; possui 50 funcionários distribuídos em quatro níveis hierárquicos e teve um faturamento da ordem de R\$ 6 milhões em 1998. Para o ano de 1999 espera-se um crescimento significativo das vendas, devendo atingir o faturamento bruto de R\$17 milhões. Seus principais clientes são os fabricantes de aglomerados de madeira, empresas de grande porte e algumas multinacionais. O seu processo de produção é constituído de duas unidades independentes: a unidade de produção do formol, que é um processo contínuo e a unidade de produção da resina de uréia formol, que é um processo em batelada. $O$ formol produzido é transferido para tanques de estocagem onde é posteriormente encaminhado para a unidade de resina ou embalado para ser vendido. As matérias-primas são nacionais.

A sua linha de produtos sofreu poucas alterações nos últimos anos e consta de cinco produtos com base no formol e cinco resinas de uréia formol.

A empresa B gasta aproximadamente $0,14 \%$ do faturamento com treinamento e não soube informar quanto gastam com P\&D, mas presume-se que seja um valor insignificante. A mão-de-obra representa $8 \%$ do custo total.

\subsubsection{A história da empresa B}

A empresa B foi fundada em 1981 por dois irmãos que estiveram à frente da empresa durante dezessete anos. Em 1998, com dificuldades financeiras, a empresa foi vendida para dois investidores, um deles com uma larga experiência industrial, com formação universitária em administração e o outro um executivo do setor financeiro. Nestes quatorze meses que estão dirigindo a empresa, os dois novos sócios se dedicaram à sua recuperação através da reestruturação organizacional e investimentos no processo produtivo.

Durante a gestão anterior, aparentemente, foram tomadas algumas decisões de investimentos com resultados negativos para a empresa, o que provavelmente contribuiu para a sua deterioração financeira. O investimento numa nova unidade de formol, com previsão de dispêndio da ordem de dois e meio milhões de dólares, foi interrompido após as etapas de projeto de engenharia e parte da construção e compra de equipamentos. Um outro investimento em uma nova unidade de produção de hexamina foi projetado e executado até o final, mas não se tornou operacional, isto é, nunca produziu a hexamina comercialmente. Esses dois projetos foram abandonados, causando um considerável prejuízo financeiro, além do desgaste da direção e do ambiente de descrença entre os funcionários. 
Com a venda da empresa e um dos novos sócios assumindo a função de diretor presidente, foi iniciado um período de recuperação.

Quando os novos proprietários assumiram a direção da empresa encontraram diversos problemas, alguns críticos para a sobrevivência da empresa no médio prazo. Estes problemas, aparentemente, eram mais graves em três frentes: na fábrica, onde a produção era de um terço da capacidade nominal da planta; na administração, que não estava estruturada para coletar e analisar as informações; no ambiente geral da empresa.

Durante os primeiros doze meses, a nova direção da empresa centralizou seus esforços na organização da administração e melhoria do processo produtivo. Foi desenvolvido um novo sistema de informação gerencial, permitindo que a direção da empresa acompanhasse a evolução da produção e o custo de cada produto. Ao mesmo tempo, foram feitas diversas pequenas melhorias no processo de produção para aumentar a capacidade da planta. Após um ano, a situação tornou-se sensivelmente melhor, a produção chegou a ficar próxima da capacidade nominal da planta, havia um sistema de informações em operação e talvez o mais importante, o ambiente da empresa era completamente diferente, com os funcionários motivados. Os resultados também melhoraram, a empresa conseguia produzir mais e vender praticamente tudo que produzia.

A previsão de faturamento para 1999 em $\mathrm{R} \$ 17$ milhões, comparada às vendas de 1998, de R\$ 6 milhões, demonstra o esforço de recuperação da empresa empreendido durante este período.

\subsubsection{O mercado da empresa $B$}

A empresa B produz e comercializa duas linhas de produtos: uma composta de cinco produtos com base no formol, sendo quatro com diferentes concentrações e um com estabilidade a frio maior, a segunda com cinco resinas de uréia formol em diferentes viscosidades e reatividades.

O formol ou aldeído fórmico é conhecido pela sua ação anti-séptica e empregado na composição de outros produtos químicos, como por exemplo, na produção de alguns desinfetantes domiciliares e hospitalares, bem como na produção da resina de uréia formol, que é também produzido pela própria empresa $\mathbf{B}$.

A resina de uréia formol tem diversas aplicações e também é empregada como matéria-prima de outros produtos, principalmente na fabricação de aglomerados e compensados de madeira.

A empresa B possui aproximadamente noventa clientes ativos, entre empresas de pequeno porte e grandes empresas, em geral, multinacionais.

O formol e a resina de uréia formol devido às suas características enquanto produto industrial, tais como mercado de tamanho grande e concentrado, alto volume de 
comercialização, baixa margem de lucro e por se tratarem de produtos que estão no mercado há muito tempo, podem ser considerados como "commodities" ou "pseudocommodities", conforme a classificação proposta pelo COINCO (1985).

\subsubsection{A administração da inovação na empresa $B$}

Durante a gestão anterior, a empresa B praticamente não desenvolvia nenhum novo produto há vários anos. Diversas tentativas de desenvolver o processo produtivo foram empreendidas sem resultados positivos.

A nova direção da empresa, após a fase inicial de reorganização, percebeu que apesar dos resultados terem melhorados, ainda seria necessário aumentar sensivelmente a produtividade e a lucratividade para que a empresa pudesse se tornar competitiva. O caminho escolhido foi a mudança gradativa da relação entre as quantidades de formol e resina produzidos e, ao mesmo tempo, a modernização do processo produtivo. Isto foi decidido com o intuito de reduzir os custos de fabricação e aumentar a lucratividade.

Na verdade, não havia muitos caminhos alternativos neste nível de análise, uma vez que o processo de produção estava obsoleto e os produtos comercializados são basicamente commodities. A atividade de desenvolvimento de novos produtos, no caso de uma empresa de pequeno porte que atua em um mercado de commodities, como a empresa B, fica restrita a pequenas modificações e adaptações do produto para atender a determinados clientes.

O formol e a resina de uréia formol podem ser considerados commodities, mas na cadeia de produção, o formol é um produto básico que vem antes da resina e portanto, possui um valor agregado menor. Desta forma, a rentabilidade da empresa $B$ depende da combinação das quantidades de formol e resina que são vendidas. Neste sentido, a nova direção da empresa procurou alterar a combinação, aumentando a quantidade de resina e reduzindo o formol. A estratégia a médio prazo é praticamente transformar todo o formol produzido em resina para se tornar um grande produtor de resina de uréia formol. Aparentemente, esta estratégia está dando bons resultados, pois a produção de resinas que antes era de 300 toneladas por mês, passou para 1200 toneladas após um ano. Para isso, foi necessário comprar formol no mercado, uma vez que a produção interna não é suficiente.

A necessidade de aumentar a produção e de reduzir o custo de fabricação do formol ficou ainda mais clara após o sucesso da nova estratégia e o acompanhamento do custo através do novo sistema de informações.

Assim, as inovações na empresa B estão fortemente concentradas no processo de produção. 
O quadro 4.3 apresenta um resumo dos principais dados referentes ao processo de inovação na empresa B, conforme a declaração dos entrevistados, isto é, de acordo com o ponto de vista da empresa.

\section{Quadro 4.3 Resumo dos dados sobre inovação - empresa B}

1) Objetivo maior da empresa

- Aumentar a produtividade, ocupar um lugar no mercado.

2) Relação das inovações com objetivo

- Possibilita aumentar a capacidade e reduzir o custo.

3) Importância dos novos produtos/processo

- Vital para sobrevivência no longo prazo.

4) Posição da empresa em relação aos concorrentes

- Muito inovadora.

5) Visão sobre o setor que atua

- Neutro, pequena pressão dos grandes clientes. 
6) Por que decidiu inovar

a) Crescer e sobreviver, permanecer no mercado.

a1) Ter escala de produção e de negociação na compra.

a2) Conseguir condição igual ou superior aos concorrentes em preço e qualidade.

b) O que fez a empresa tomar essa decisão

- Adoção de nova tecnologia para redução de custo, estratégia da empresa em se manter atualizada.

c) Maiores dificuldades

- Recursos financeiros, conseguir uma equipe enfocada na real necessidade da empresa.

d) Benefícios para a empresa

- Conseguir ver um caminho através dos resultados.

\subsubsection{A tomada de decisão na empresa B}

A decisão estratégica em desenvolvimento do processo na empresa B é tomada, em geral, pelo Diretor Presidente e seu sócio. Durante o processo de coleta de dados, análise e discussão, os principais gerentes têm participação ativa. Neste processo, a opinião e participação do Gerente Industrial é fundamental, por ser a pessoa que dá o suporte técnico às decisões.

\section{A decisão estudada}

Para análise da tomada de decisão e por sugestão dos entrevistados, foi considerada a decisão de modificação da unidade de formol para produzir o concentrado de uréia formol, CUF.

Não houve um fato, segundo o Diretor Presidente, que tenha marcado a decisão de desenvolver o processo de produção do formol. A decisão foi se amadurecendo à medida que novas informações surgiram, ao longo de alguns meses de coleta de dados, análises e intensas discussões sobre o assunto.

O CUF é uma tecnologia de processo existente há muitos anos e mais recentemente tornou-se de domínio público, não havendo, portanto, direitos a serem pagos para o seu uso. Ainda assim, em relação ao processo atual da empresa B, o CUF possibilitaria uma redução de aproximadamente $3 \%$ das matérias-primas na produção da resina e praticamente dobrar a capacidade da unidade. 
As vantagens de se alimentar a unidade de resina com CUF ao invés de formol eram nítidas e conhecidas de longa data dos técnicos da empresa; a questão que surgia era de ordem financeira. Uma nova unidade para produzir CUF custava por volta de dois e meio milhões de dólares e não havia esse recurso.

Após analisarem diversas alternativas para produzir o CUF, conseguiram descobrir uma forma que se mostrou economicamente viável. Esta alternativa seria a modificação da unidade atual de formol para produzir tanto o formol como o CUF. Embora possa parecer que a solução encontrada fosse óbvia, essa mesma alternativa já havia sido descartada anteriormente devido seus aspectos negativos. Basicamente, os pontos negativos eram a necessidade de parada da unidade por um período prolongado para realizar as modificações, o custo para realizar as modificações e uma parada por período menor cada vez que houvesse a passagem de CUF para formol. Esses mesmos aspectos, quando analisados com maior profundidade, não mais se mostraram assim tão negativos.

$\mathrm{Na}$ ocasião da entrevista a empresa $\mathbf{B}$ havia tomado a decisão de investir no desenvolvimento do processo há algumas semanas e estava na fase de detalhamento do projeto. O investimento previsto é da ordem de $\mathrm{R} \$ 400.000$.

O quadro 4.4 apresenta a avaliação (do pesquisador) de uma decisão tomada pela empresa B, de acordo com o método proposto por Matheson \& Matheson (1998). Cada quesito foi avaliado com uma nota que pode variar de 1 a 7 .

\section{Quadro 4.4 Qualidade da tomada de decisão - empresa B}

\section{Projeto de inovação escolhido}

- Modificação no processo de produção do formol.

- Em andamento.

\section{Estrutura da decisão}

- As principais áreas da empresa participam da análise das alternativas.

- Muitas questões foram geradas na análise do projeto.

- Riscos e benefícios parcialmente analisados.

- Avaliação: 6

\section{Alternativas}

- Levantadas diversas alternativas.

- Foram feitas avaliações quantitativas das alternativas.

- Foi criado um comitê para implementar a decisão.

- Avaliação: 7

\section{Informações}

- Não foi feita avaliação da probabilidade de sucesso, técnico e de mercado.

- As principais informações foram coletadas.

- Utilizou recursos externos (consultoria em engenharia de processo).

- Avaliação: 5 


\section{Raciocínio lógico}

- Utiliza alguns métodos quantitativos.

- Aparentemente o projeto sofreu alterações.

- Avaliação: 5

\section{Valores e trade offs}

- Relação entre risco e retorno do projeto parcialmente conhecida.

- Avaliado o impacto do projeto no fluxo de caixa.

- Não avaliado o custo da falha.

- Avaliação: 5

\section{Compromisso para ação}

- Os responsáveis pela implementação participam da decisão.

- Não houve discordância quanto à decisão.

- Riscos e benefícios parcialmente divulgados.

- Avaliação: 6

\section{Figura 4.3 Diagrama tipo aranha - empresa B}

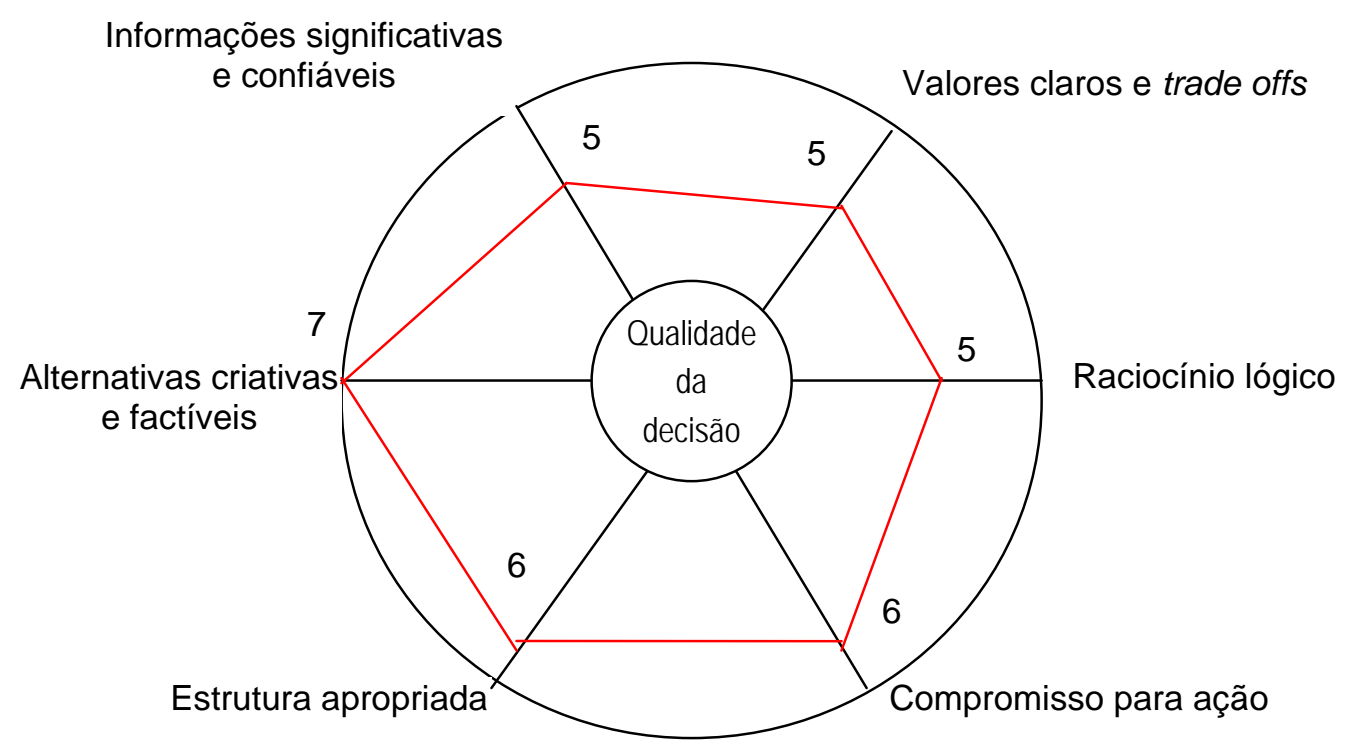

A figura 4.3 ilustra a qualidade da decisão tomada na empresa B. Nos quesitos informações, valores e trade offs e raciocínio lógico atingiu-se $71 \%$ do máximo. Em estrutura e compromisso para ação chegou a 85\% e no quesito alternativas, atingiu o máximo. De maneira geral a tomada de decisão está homogênea e com alto nível em todos quesitos.

\subsubsection{Percepção e tolerância ao risco na empresa B}


Para avaliar a percepção e tolerância ao risco da empresa B foram aplicados os dois testes previstos na metodologia em um diretor e um gerente, que representam os principais decisores da empresa em desenvolvimento de processo.

Os resultados do teste de percepção do risco e tolerância ao risco são apresentados na tabela 4.4 e 4.5 , respectivamente.

Tabela 4.4 Resultado do teste de percepção do risco - empresa B

\begin{tabular}{|c|c|}
\hline Participante & Probabilidade atribuída (\%) \\
\hline a (diretor executivo, acionista) & 40 \\
\hline b & 75 \\
\hline Média & 57,5 \\
\hline
\end{tabular}

Tabela 4.5 Resultado do teste de tolerância ao risco - empresa B

\begin{tabular}{|c|c|c|}
\hline Participante & Tolerância (R em R\$) & Tolerância (\% das vendas) \\
\hline a & 240.000 & 2,1 \\
\hline b & 700.000 & 6,1 \\
\hline Média & 470.000 & 4,1 \\
\hline
\end{tabular}

A identificação dos decisores $(a, b)$ foi mantida para os dois testes.

Para cálculo da tolerância em \% das vendas foi considerado como valor das vendas a média dos faturamentos de 1998 e 1999, R\$11,5 milhões. 


\subsection{Caso II (empresa C)}

Para coletar os dados da empresa $\mathbf{C}$ foram realizadas duas entrevistas com o diretor comercial, uma entrevista com o diretor industrial, uma entrevista com o diretor técnico e uma visita à fabrica.

A empresa C é uma indústria que no passado foi de médio porte e hoje pode ser considerada de pequeno porte. A empresa tem hoje 96 funcionários distribuídos em quatro níveis hierárquicos e, de acordo com o critério de classificação do porte da empresa por número de funcionários, está praticamente no limite entre pequena e média empresa.

A empresa produz e comercializa especialidades químicas, está instalada no subúrbio do Rio de Janeiro em uma área de $28.000 \mathrm{~m}^{2}$, com um faturamento anual da ordem de R\$ 7 milhões, praticamente estável durante os últimos dois anos. Possui clientes em diversas áreas de negócio, tais como metalúrgica, química, eletrônica, aeronáutica e outros, em sua maioria empresas de grande porte. O seu processo de produção é bastante simples, em bateladas, constando basicamente de reatores, misturadores e tanques. Cerca de 95\% das matérias-primas são nacionais.

A empresa possui dois laboratórios, um para controle da qualidade e outro para desenvolvimento de novos produtos. A sua linha de produtos, em 1998, tinha cerca de 700 produtos, sendo que aproximadamente 500 foram comercializados no mesmo ano. As oportunidades de negócio que surgiram foram definindo a linha de produtos. Basicamente, a estratégia maior da empresa foi desenvolver novos produtos para os segmentos de mercado que utilizassem produtos importados ou precisassem de um produto não disponível no mercado brasileiro para resolver algum problema.

O atendimento a tantos setores distintos de negócio, como por exemplo, uma fábrica de bicicletas e uma indústria alimentícia, trouxeram algumas vantagens e outras tantas desvantagens. A principal vantagem foi não ser afetada por eventuais crises de um determinado setor, pois sempre tem sido possível compensar as perdas de vendas desse setor com o esforço para vender em outro. Por outro lado, as desvantagens aparentemente são maiores. Os estoques de matéria-prima e sobras de lotes dos produtos acabados aumentaram demasiadamente, prejudicando a rentabilidade. Outra dificuldade foi conseguir prestar um bom serviço de assistência técnica. Tornou-se impossível treinar e manter uma equipe que atendesse às necessidades dos clientes.

Em 1999, perceberam que seria inviável manter uma linha de produtos tão extensa e começaram um programa de redução, tirando da linha os produtos menos rentáveis e aqueles que não haviam sido vendidos nos últimos meses. Hoje, estão com aproximadamente 250 produtos na linha. 
A empresa gasta aproximadamente $1 \%$ do faturamento com P\&D, não considerando a parte das despesa com assistência técnica; por volta de $2 \%$ com treinamento e a mão-deobra total (direta e indireta) representa aproximadamente $30 \%$ do custo total do produto.

\subsubsection{A história da empresa C}

A empresa C foi fundada em 1967, com o objetivo de produzir colas à base de neoprene e resinas fenólicas, uma das matérias-primas da cola. Posteriormente, passaram a produzir material de limpeza doméstica e finalmente, por volta de 1975, começaram a produzir especialidades químicas, negócio em que estão até hoje. A entrada no negócio de especialidades químicas ocorreu, quando o fundador transferiu a direção da empresa para seus três filhos. Com a nova direção, a empresa cresceu e diversificou o campo de atuação, alterando a sua composição acionária, mas continuando a ser uma empresa familiar.

A composição acionária atual é a seguinte: $71 \%$ distribuído entre os três irmãos, $10 \%$ para um diretor comercial e 19\% pertencem a um grupo inglês. Os três irmãos ocupam as funções de diretor industrial, diretor técnico e diretor administrativo financeiro. Os dois primeiros são engenheiros e o terceiro é administrador de empresas, assim como o diretor comercial.

A entrada do grupo inglês ocorreu há uns quinze anos, como resultado de uma negociação para fornecimento da tecnologia de produtos químicos para aviação. Nesta ocasião, foi fundada uma nova empresa (C') específica para o negócio de produtos químicos para aviação, com $51 \%$ da empresa C e $49 \%$ do grupo inglês. Como parte da negociação, o grupo inglês passou a contar com 19\% do capital da empresa C. A empresa C' continua ativa, com um pequeno corpo de funcionários que cuida da comercialização e assistência técnica, enquanto a empresa $\mathbf{C}$ é a responsável pela produção de toda a linha de produtos da empresa C'. Esses produtos são específicos para aplicação em aeronáutica, tais como emulsão de tinta, produtos para tratamento de metal, produto para detecção de trincas, shampoo, desengraxantes e outros. Hoje, a empresa C' tem uma participação de aproximadamente $85 \%$ nesse mercado, composto das empresas de aviação e da aviação militar. Esse mercado, que já propiciou à empresa C' um faturamento de $\mathrm{R} \$ 600.000$ por mês, nos últimos quatro anos, com a crise da aviação, tem representado um faturamento mensal de apenas $\mathrm{R} \$ 100.000$.

Uma das principais características da empresa $\mathbf{C}$, ao longo dos trinta e dois anos de sua existência, tem sido a grande variedade de produtos desenvolvidos, chegando a ter, em 1998, cerca de setecentos itens na sua linha de produtos. Segundo a direção da empresa, esta característica é inerente ao próprio tipo de negócio, uma vez que a empresa se propõe a vender soluções aos problemas dos clientes e não um produto isoladamente. 


\subsubsection{O mercado da empresa C}

Como um fabricante de especialidades químicas, a empresa C procura atender diversos segmentos de mercado. Em geral, estes segmentos compram pequenos volumes do produto para aplicações específicas e estão distribuídos em inúmeros setores da atividade econômica, tanto industrial como comércio e serviços.

A estratégia de crescimento da empresa tem sido a de entrar em segmentos de mercado onde não existe forte concorrência de preços, o volume movimentado seja pequeno e os clientes necessitem de um suporte técnico para aplicação do produto. Segundo seus diretores, esta estratégia pode ser resumida como: atuar em mercados que não sejam atraentes para as grandes empresas e ao mesmo tempo exijam uma competência técnica e investimentos em assistência, que dificulte a entrada de pequenas empresas.

A linha de produtos está dividida em sete categorias, conforme a aplicação do produto e segmentos de mercado, que são os seguintes: divisão de especialidades químicas (antiespumantes, produtos para lavanderia, aditivos e outros); divisão de tratamento de metais (desengraxante, aditivos, produtos para tratamento e outros); desmoldantes; divisão de lubrificantes (fluidos hidráulicos, graxas, óleos diversos); divisão de produtos para eletrônica (removedores de filmes, condicionadores de estanho e outros); produtos para siderúrgicas (inibidor de corrosão, auxiliar de rinçagem e outros); produtos para tratamento de água.

A maior parte dos clientes são grandes empresas, principalmente multinacionais. Estas empresas, em geral, são os primeiros clientes de um determinado tipo de produto que posteriormente é oferecido às outras empresas da cadeia de produção, às outras fábricas da empresa e eventualmente aos concorrentes. Esta estratégia pode ser atestada através dos seguintes exemplos de desenvolvimentos de produtos: a) produtos para trefilação de cobre; b) óleo para usinagem de alumínio; c) produto para limpeza industrial.

a) o desenvolvimento de produtos para trefilação do cobre ocorreu, quando grandes fabricantes de fios de cobre se defrontaram com o problema de não poderem utilizar o óleo de baleia como óleo solúvel para operar a trefilação. Nesta ocasião, um diretor da empresa C foi aos Estados Unidos e conseguiu comprar de uma tradicional empresa americana neste negócio, a formulação para uma linha completa de produtos para trefilação e estampagem. Após algumas adaptações, nacionalização das matérias-primas e testes, conseguiram atender os grandes clientes, que por sua vez, indicaram outras empresas na cadeia de produção. Hoje, a empresa C tem aproximadamente $90 \%$ desse mercado.

b) A usinagem de alumínio é uma operação mecânica, que requer cuidados especiais para se obter um bom acabamento da peça; quando esta peça é o pistão de um 
motor a explosão, a precisão e acabamento são requisitos indispensáveis. Apenas duas grandes empresas fabricavam este tipo de peça. Quando, há alguns anos, uma dessas empresas precisava melhorar o acabamento das peças, a empresa C novamente recorreu ao seu parceiro americano e conseguiu produzir um óleo que atendesse a necessidade do cliente e hoje, tem participação de praticamente $100 \%$ nesse mercado.

c) Produtos para limpeza industrial compreendem uma enorme variedade de formulações, cada uma específica para as condições e objeto da limpeza.

Há vinte anos, quando uma grande fabricante de copiadoras alugava suas máquinas, o serviço de recuperação destas máquinas que retornavam após o aluguel era uma etapa importante do seu negócio. As máquinas precisavam estar completamente limpas e recondicionadas antes de serem novamente alugadas. Essa limpeza era feita com solvente orgânico sob pressão e causava sérios problemas ambientais. A empresa C, com o apoio da fabricante de copiadoras, visitou algumas fábricas nos Estados Unidos que já utilizavam um novo produto para limpeza. Nessas visitas, manteve contato com um fabricante de produtos de limpeza e comprou a formulação de um produto à base de água para substituir o solvente. Este produto foi adaptado às condições brasileiras, testado e aprovado, sendo vendido para a fabricante de copiadoras, do Brasil e do México, até hoje.

É difícil falar em um tipo de concorrente, dado que a empresa $\mathbf{C}$ atua em tantos setores distintos. Existem concorrentes de todos os portes. As grandes empresas, apesar de não terem interesse específico em determinados segmentos, podem se tornar um concorrente, à medida que utilizam a estratégia de penetrar em determinado mercado ou cliente com um produto de linha adaptado para aquelas condições. Também ocorre o crescimento de um segmento, que no início não era atraente para uma grande empresa, mas com o crescimento torna-se interessante. Os pequenos concorrentes são, em geral, as empresas especializadas em determinado campo. Essas empresas possuem melhor capacitação técnica no campo que atuam e estão habilitadas a prestar uma boa assistência técnica, mas normalmente seus preços são altos. 


\subsubsection{A administração da inovação na empresa C}

De certo modo, poderia se dizer que a inovação faz parte do próprio negócio da empresa C. Criar novos produtos que resolvam problemas dos clientes.

A idéia dos novos produtos surge quase que exclusivamente das observações da equipe de vendas e assistência técnica sobre as necessidades de solução de problemas dos clientes. Essas observações são levadas para o diretor comercial, se possível com alguns dados básicos sobre características desejadas do produto, volume a ser consumido e outros, para uma análise preliminar. Havendo interesse comercial no fornecimento, a idéia é discutida com a área técnica, que pode indicar a utilização de um produto já existente, ou definir a necessidade de um novo produto. Apesar da assistência técnica pertencer à área comercial, sediada em São Paulo, enquanto a fábrica, o laboratório e a direção técnica estão no Rio de Janeiro, a empresa é ágil em suas avaliações técnicas, comerciais e financeiras. Isto se deve, aparentemente, ao porte da empresa e o bom entrosamento entre as diversas áreas operacionais. Quando não existe um produto para atender o cliente, o assunto é discutido entre os diretores técnico, industrial e comercial. Nessa etapa, decide-se se o novo produto será ou não desenvolvido, e como isto será feito. Este processo tem demonstrado ser bastante ágil na tomada de decisão e atendimento do cliente, mas por outro lado, um tanto ineficiente e custoso para a empresa. Aproximadamente $50 \%$ dos primeiros testes realizados pelo cliente têm reprovado o produto desenvolvido, provocando novas adaptações na formulação, novas amostras e repetição dos testes. Essas reprovações acarretam custos extras e um certo desgaste na imagem da empresa.

Com o programa de redução dos itens da linha de produtos iniciado este ano, a empresa está procurando redirecionar o processo de desenvolvimento, de tal forma que se torne mais seletiva na aprovação das idéias e mais cuidadosa no desenvolvimento, evitando, assim, o aumento da linha de produtos e reduzindo o custo de desenvolvimento.

A empresa $\mathbf{C}$ tem utilizado diversas formas e recursos para adquirir tecnologia. Algumas vezes compram a formulação de empresas do exterior ou se associam com essas empresas para produzir uma nova linha de produtos no Brasil. Esse caminho tem sido usado, em geral, para as inovações de maior dificuldade no seu desenvolvimento, como uma forma de ingressar em novos setores. Outras vezes, a empresa utiliza a contratação de especialistas para desenvolver internamente os novos produtos. Essas contratações são feitas no mercado brasileiro, buscando-se profissionais com conhecimentos e experiência específica, ou trazidos do exterior por determinado período.

O quadro 4.5 apresenta um resumo dos principais dados referentes ao processo de inovação na empresa C, conforme a declaração dos entrevistados, isto é, de acordo com o ponto de vista da empresa. 


\section{Quadro 4.5 Resumo dos dados sobre inovação - empresa C}

1) Objetivo maior da empresa

- Reduzir a linha de produtos, solidificar a posição, aumentar rentabilidade.

2) Relação das inovações com objetivo

- Novos produtos são inerentes ao negócio.

3) Importância dos novos produtos/processo

- Vital para sobrevivência da empresa, faz parte do negócio.

4) Posição da empresa em relação aos concorrentes

- Muito inovadora.

5) Visão sobre o setor que atua

- Muito inovador.

6) Por que decidiu inovar

a) Para conseguir se diferenciar.

a1) Para ser diferente no atendimento ao cliente, atender suas necessidades.

a2) Para poder permanecer no mercado.

b) O que fez a empresa tomar essa decisão

- Observação do mercado.

- Ameaça de produtos importados.

- Mudança na legislação.

- Estratégia da empresa.

c) Maiores dificuldades

- Acesso às matérias-primas importadas.

d) Benefícios para a empresa

- Manter a carteira de clientes mesmo em situações de crise. 


\subsubsection{A tomada de decisão na empresa C}

A decisão em desenvolvimento de novos produtos na empresa $C$, em geral, é tomada com a participação do diretor comercial e do diretor técnico. Eventualmente, e dependendo da importância do novo produto, também existe a participação do diretor industrial e financeiro.

\section{A decisão estudada}

Para análise da tomada de decisão e por sugestão dos entrevistados foi considerado o desenvolvimento de um produto para limpeza e fosfatização do alumínio. A idéia de desenvolver este produto surgiu da observação da equipe de vendas e posterior acompanhamento do diretor de vendas. O cliente, um grande fabricante de unidade de refrigeração para geladeiras, estava diante de um novo problema. Durante o processo de produção do evaporador, duas placas de alumínio previamente preparadas são coladas e passam por outras operações para chegar à etapa final de limpeza. Nessa etapa, é necessário remover os resíduos incorporados durante a fase anterior, tais como óleo e grafite. Para fazer a limpeza, o fabricante utilizava uma solução à base de soda cáustica que ataca a superfície de alumínio e extrai os resíduos da fabricação. O problema surgiu quando passaram a utilizar um novo gás para refrigeração; os resíduos de soda que ficavam após a limpeza reagiam com o gás e criavam incrustações nos canais do evaporador. A empresa $C$ analisou o problema, verificou que tinha condições de desenvolver um produto que não fosse à base de soda e decidiram desenvolvê-lo. Após algumas tentativas e testes, chegaram à formulação de um produto que atendia plenamente o cliente. Hoje, a empresa $\mathrm{C}$ é o fornecedor exclusivo deste produto para os dois maiores e únicos fabricantes de refrigeradores, tem $100 \%$ de participação neste pequeno segmento de mercado que consome sete mil litros por mês do produto ao preço de $\mathrm{R} \$ 5,00$ por litro.

Nesse caso, a decisão de desenvolver o novo produto coube aos diretores comercial e técnico, com a participação de outros técnicos durante a fase de coleta de dados. Não foi feita nenhuma análise de risco; em geral, não são consideradas a possibilidade de fracasso no desenvolvimento nem os custos envolvidos.

O quadro 4.6 apresenta a avaliação (do pesquisador) de uma decisão tomada pela empresa C, de acordo com o método proposto por Matheson \& Matheson (1998). Cada quesito foi avaliado com uma nota que pode variar de 1 a 7 . 


\section{Quadro 4.6 Qualidade da tomada de decisão - empresa C}

\section{Projeto de inovação escolhido}

- Desenvolvimento de um produto para limpeza e fosfatização do alumínio.

- Realizado há aproximadamente seis meses.

\section{Estrutura da decisão}

- As principais áreas participam da coleta de dados; dois diretores decidem.

- Poucas questões são geradas na análise.

- Riscos não são analisados e benefícios superficialmente.

- Avaliação: 4

\section{Alternativas}

- Levantadas poucas alternativas.

- Não são feitas avaliações quantitativas das alternativas.

- Não foi definido um plano para implementação da decisão.

- Avaliação: 4

\section{Informações}

- Não foi feita avaliação da probabilidade de sucesso, técnico e de mercado.

- As principais informações foram coletadas.

- Utilizou recursos externos.

\section{- Avaliação: 5}

\section{Valores e trade offs}

- Relação entre risco e retorno do desenvolvimento desconhecida.

- Não avaliado o impacto do desenvolvimento no fluxo de caixa.

- Não avaliado o custo da falha.

- Avaliação: 3

\section{Raciocínio lógico}

- Utiliza alguns métodos quantitativos.

- Aparentemente o desenvolvimento sofreu alterações.

- Avaliação: 4

\section{Compromisso para ação}

- Os responsáveis pela implementação participam parcialmente da decisão.

- Não houve discordância quanto à decisão.

- Riscos e benefícios não foram divulgados.

- Avaliação: 5 
Figura 4.4 Diagrama tipo aranha - empresa C

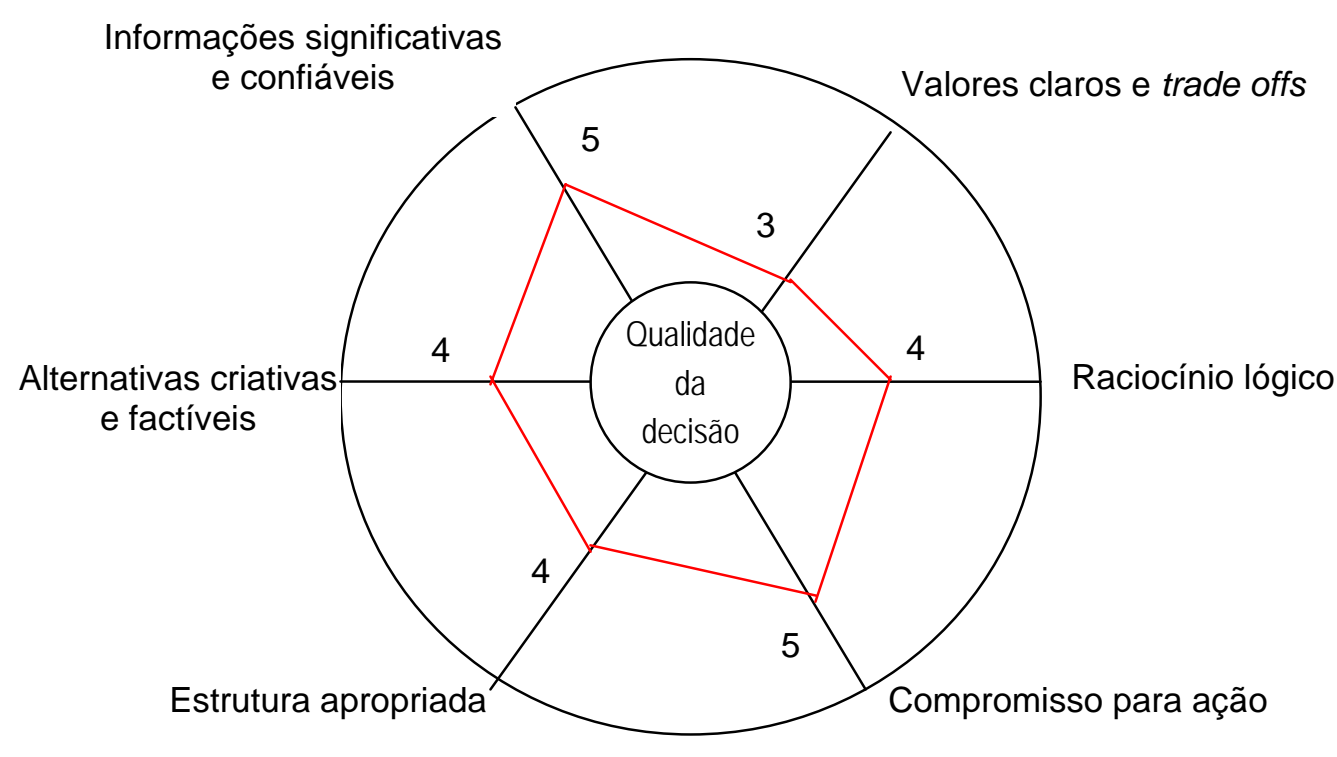

A figura 4.4 ilustra a qualidade da decisão tomada na empresa C. Apenas os quesitos informações e compromisso para ação atingiram um bom nível. Trade offs com $43 \%$ do nível máximo é o quesito mais fraco. Estrutura, alternativas e raciocínio lógico atingiram $57 \%$ do máximo e podem ser considerados razoáveis. De maneira geral, a tomada de decisão não está homogênea e com apenas dois quesitos em bom nível. 


\subsubsection{Percepção e tolerância ao risco na tomada de decisão}

Para avaliar a percepção e tolerância ao risco da empresa $\mathbf{C}$, foram aplicados os dois testes previstos na metodologia, em três diretores, que representam os principais decisores da empresa.

Os resultados do teste de percepção do risco e tolerância ao risco são apresentados na tabela 4.6 e 4.7, respectivamente.

Tabela 4.6 Resultado do teste de percepção do risco - empresa C

\begin{tabular}{|c|c|}
\hline Participante & Probabilidade atribuída (\%) \\
\hline a (diretor Industrial, maior acionista) & 80 \\
\hline b & 58 \\
\hline c & 50 \\
\hline Média & 62,7 \\
\hline
\end{tabular}

Tabela 4.7 Resultado do teste de tolerância ao risco - empresa C

\begin{tabular}{|c|c|c|}
\hline Participante & Tolerância (R em R\$) & Tolerância (\% das vendas) \\
\hline a & 80.000 & 1,1 \\
\hline b & 420.000 & 6,0 \\
\hline c & 300.000 & 4,3 \\
\hline Média & 266.667 & 3,8 \\
\hline
\end{tabular}

A identificação dos decisores ( $a, b, c)$ foi mantida para os dois testes.

Para cálculo da tolerância em \% das vendas, foi considerado como valor das vendas a média dos faturamentos de 1998 e 1999, R\$ 7 milhões, 


\subsection{Caso III (empresa D)}

Para coletar os dados da empresa $\mathbf{D}$ foram realizadas duas entrevistas, uma com o diretor técnico e outra com o diretor comercial, e uma visita à fábrica.

A empresa D é uma indústria de pequeno porte com apenas alguns anos de existência, que produz e comercializa especialidades químicas; com uma fábrica instalada em uma pequena cidade próxima a São Paulo e um escritório no centro da cidade, possui apenas 30 funcionários distribuídos em três níveis hierárquicos. O seu processo de produção é bastante simples e flexível, constituído basicamente de misturadores e tanques; pode produzir bateladas de alguns litros, até milhares de litros, em estado líquido, pó ou pasta. Aproximadamente $90 \%$ das matérias-primas são nacionais.

A empresa possui dois laboratório, um para controle da qualidade e outro para desenvolvimento de novos produtos. Possui uma linha de produtos com 250 itens, sendo que durante os últimos anos têm havido uma constante renovação de aproximadamente 30 itens por ano. Os produtos lançados nos dois últimos anos, por volta de 60, são responsáveis por aproximadamente $30 \%$ do faturamento atual.

Ao contrário da maioria das indústrias químicas que atuam no ramo de especialidades, a empresa $\mathbf{D}$ definiu claramente seus objetivos e as áreas que em pretendia atuar, antes de entrar em operação. O negócio de especialidades químicas ou química aplicada se caracteriza por produtos cujo valor está na sua capacidade de resolver adequadamente os problemas dos clientes, independente da sua composição. Em geral, são classificados de acordo com sua aplicação. No caso da empresa $\mathbf{D}$, definiu-se que seus produtos seriam para aplicação industrial e institucional.

Os quatro sócios proprietários traçaram como objetivo criar uma empresa com um estilo moderno de gestão, que pudesse crescer, que não se tornasse familiar, de alto nível técnico, idônea e que fosse capaz de competir com as melhores empresas. Essa empresa buscaria ser eficiente no seu negócio, concentrando-se nele e evitando a verticalização das atividades, procurando entregar para terceiros todos os serviços possíveis que não fizessem parte do seu core business. De fato, os 30 funcionários atuais se ocupam das áreas de produção, marketing, $P \& D$, finanças e parte da administração, enquanto aproximadamente outros 50 funcionários de terceiros são responsáveis pelos serviços gerais (como limpeza, segurança e manutenção), vendas, informática, contabilidade, assuntos jurídicos e outros.

A empresa $\mathbf{D}$ teve um faturamento bruto em 1998 de $R \$ 4$ milhões e espera alcançar algo entre R\$ 5 milhões e R\$ 6 milhões no ano de 1999. Gastam por volta de 1\% do faturamento com P\&D e a mão-de-obra direta representa $4 \%$ do custo total, enquanto a mão-de-obra indireta representa $8 \%$. Estimam que $5 \%$ do tempo de todos os funcionários seja dedicado a treinamento. 


\subsubsection{A história da empresa D}

A empresa D foi fundada em junho de 1990, por quatro amigos e ex-funcionários de uma indústria multinacional química, no início, apenas como uma empresa comercial que se utilizava da produção de terceiros. Em outubro de 1992, completaram a construção de uma fábrica e passaram a operar como indústria e comércio.

Os quatro sócios proprietários e fundadores da empresa D são engenheiros (3) e administrador de empresas. Os quatro tornaram-se os diretores operacionais e cada um atuando na sua área de conhecimento. O conhecimento e experiência da direção no negócio de especialidades químicas, adquiridos durante os vários anos em que trabalharam em uma grande indústria, possibilitaram vencer o difícil começo da empresa. Nessa fase, utilizaram a capacidade e reputação individual que tinham no mercado, principalmente nas áreas de marketing e P\&D, para penetrar nas grandes indústrias e divulgar o nome da empresa.

\subsubsection{O mercado da empresa D}

O mercado de especialidades químicas abrange um leque muito grande de produtos e aplicações. Esta característica, que é atraente para as empresas em geral e em especial para as pequenas, pelo enorme mercado potencial, pode se tornar uma armadilha perigosa se não houver uma definição dos mercados e da forma que se pretende atendê-los.

No caso da empresa $D$, esta definição foi feita nos seguintes aspectos:

- participar de mercados onde o nível de exigência do cliente, em relação ao desempenho do produto, seja alto. Em conseqüência, os fornecedores são empresas de alto nível, em geral grandes fabricantes;

- fabricar produtos químicos de alta tecnologia para os mercados institucional e industrial, preservando a qualidade do meio ambiente;

- desenvolver e produzir para terceiros, produtos e especialidades dentro do mesmo escopo da empresa;

- para definir e limitar as áreas de atuação foram criadas sete divisões comerciais:

$\Rightarrow$ Divisão alimentícia - compreende limpeza geral, lavagem de garrafas, desinfetantes e outros.

$\Rightarrow$ Divisão metalúrgica - limpadores, desengraxantes, decapantes, antiespumantes, óleos protetivos e outros.

$\Rightarrow$ Divisão institucional - higiene pessoal, higiene de cozinhas, desinfetantes e outros.

$\Rightarrow$ Divisão marca de terceiros - produz para terceiros produtos como sabão líquido, sabão para máquinas de lavar louça e outros. 


$$
\begin{aligned}
& \Rightarrow \text { Divisão doméstica - produtos para limpeza especializada com } \\
& \text { distribuidores exclusivos. } \\
& \Rightarrow \text { Divisão de produtos especiais - produtos para "salas limpas", anti- } \\
& \text { espumantes e tratamento de efluentes. } \\
& \Rightarrow \text { Divisão fosfatos - fosfatos especiais, aceleradores, decapantes e } \\
& \text { outros. }
\end{aligned}
$$

A produção para terceiros foi a forma encontrada para viabilizar a empresa no seu início, conseguindo gerar um volume para se atingir a escala mínima de produção. A filosofia com esses terceiros tem sido a de se tornar o parceiro químico de empresas não químicas. Estes parceiros são grandes supermercados, fabricantes de equipamentos industriais, fabricantes de embalagens e material de limpeza descartável e outros.

\subsubsection{A administração da inovação na empresa D}

O negócio de especialidades químicas está centrado na solução de problemas para o cliente. O sucesso de um produto está diretamente relacionado ao seu desempenho, independente do seu conteúdo, desde que não infrinja as restrições estabelecidas pelo ambiente. Esta característica leva os fabricantes de especialidades químicas a manter uma atenção especial no serviço de assistência técnica e vendas, que são as fontes de contato com o cliente e geração das idéias de inovação. Na empresa $\mathbf{D}$, o processo de inovação não foge à regra; em geral, nasce da observação da equipe comercial quando em contato com os clientes. Essas observações são discutidas com a área técnica e assim é tomada a decisão de se desenvolver ou não um novo produto.

A empresa D estabeleceu um conselho, formado pelos quatro diretores, para discutir e definir diversos assuntos, entre os quais a política de P\&D. De acordo com esta filosofia, as oportunidades de inovação devem estar dentro do escopo maior da empresa, caso contrário devem ser discutidas e aprovadas ou não pelo conselho. Quando a inovação está dentro do escopo da empresa, em princípio, basta a aprovação da área técnica para que a mesma seja aprovada. Mas esta aprovação obedece a um procedimento previamente estabelecido. Este procedimento consta de uma análise financeira e técnica preliminar para determinar a viabilidade do desenvolvimento. Se for considerado viável, é aprovado para entrar na carteira de projetos. Em geral, existem entre cinco e dez projetos na carteira, aguardando sua vez. Esses projetos são ordenados de acordo com a prioridade estabelecida pelo diretor técnico e à medida que exista disponibilidade de recursos, é iniciado o processo de desenvolvimento pela equipe de P\&D.

O desenvolvimento propriamente dito do novo produto, começa com o estudo do problema pela equipe de P\&D. Nessa fase, é feita uma discussão sobre as informações existentes e as que seriam necessárias; somente após o esclarecimento das eventuais 
dúvidas passa-se para a fase seguinte. Tal esclarecimento, freqüentement, é feito através da visita de algum membro da equipe técnica ao cliente.

Uma vez que o problema de desenvolvimento esteja claro e objetivamente definido do ponto de vista técnico, dá-se o início da fase seguinte, de busca do produto adequado às condições estabelecidas.

Não existe uma tecnologia de aplicação das especialidades químicas disponível na literatura ou em qualquer outro meio acessível. Esse tipo de tecnologia depende do conhecimento e fundamentalmente da experiência adquirida pelas pessoas na solução de problemas correlatos. Essa tecnologia consiste basicamente em saber encontrar uma formulação que consiga resolver um problema específico e ao mesmo tempo, atender às restrições ambientais e econômicas dadas.

Em geral, pratica-se o método de tentativa e erro para se conseguir chegar na formulação mais adequada. O sucesso deste método, em termos de se alcançar o objetivo e minimizar o custo do desenvolvimento, depende de dois fatores: capacitação técnica da equipe e metodologia de pesquisa. A metodologia, neste caso, significa uma padronização de procedimentos e critérios de análise e etapas que devem ser seguidas durante o processo. No caso da empresa $\mathbf{D}$, existe uma metodologia de pesquisa em uso e a preocupação com a capacitação da equipe.

Cada desenvolvimento de novo produto, no caso da empresa D, implica no teste inicial em laboratório, em média, de 30 a 40 formulações com diferentes elementos ativos.

A figura 4.5 ilustra o processo de inovação na empresa $\mathbf{D}$.

Figura 4.5 Processo de desenvolvimento de produto da empresa $D$

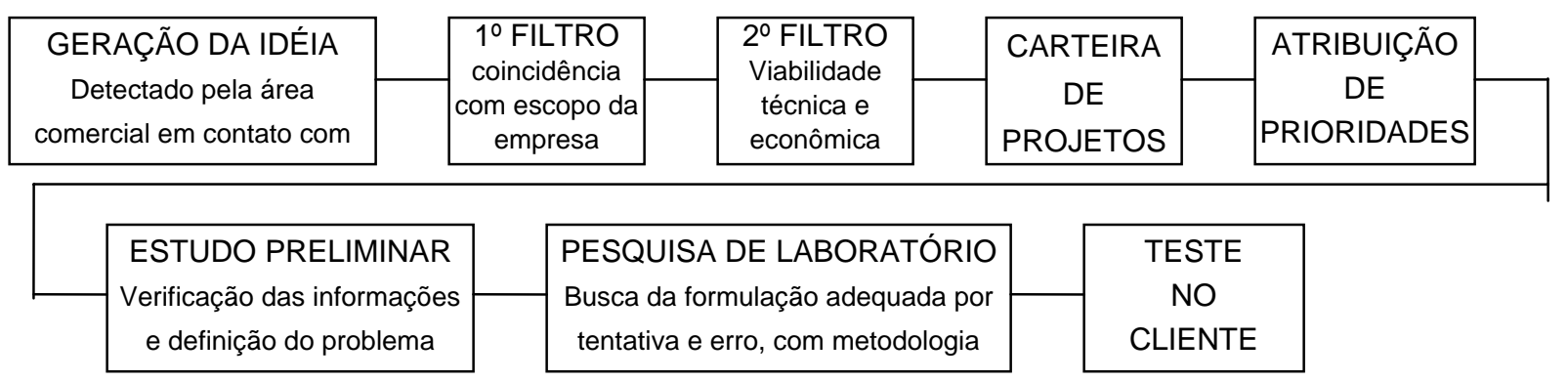


O quadro 4.7 apresenta um resumo dos principais dados referentes ao processo de inovação na empresa D, conforme a declaração dos entrevistados, isto é, de acordo com o ponto de vista da empresa.

\section{Quadro 4.7 Resumo dos dados sobre inovação - empresa D}

1) Objetivo maior da empresa

- conquistar o mercado, crescer.

2) Relação das inovações com objetivo

- Como a vida dos produtos é curta, são necessários novos produtos para manter os clientes atuais e conquistar novos.

3) Importância dos novos produtos/processo

- Em geral, a importância é alta, pois o negócio é baseado em novidades. Em alguns casos, como produtos para terceiros, depende da inovação do cliente.

4) Posição da empresa em relação aos concorrentes

- Muito inovadora.

5) Visão sobre o setor que atua

- Em geral, muito inovador. Em alguns casos ,a pressão por inovação é do cliente (mercado metalúrgico e alimentos), em outros é dos concorrentes (mercado institucional).

6) Por que decidiu inovar

a) Para conseguir se diferenciar e criar uma identidade.

a1) Os donos têm capacidade e realizam um sonho que antes (na empresa anterior) não podiam.

a2) Para sobreviver.

b) O que fez a empresa tomar essa decisão

- Pedido dos clientes.

- Observação do mercado.

- Mudança na legislação (principalmente em relação ao meio ambiente).

- Estratégia da empresa.

c) Maiores dificuldades

- Conseguir a aceitação dos grandes clientes.

- A tecnologia de aplicação não disponível.

d) Benefícios para a empresa

- Possibilidade de competir com as grandes empresas, geração de receita.

- Aumentar o valor agregado do produto. 


\subsubsection{A tomada de decisão na empresa $D$}

A empresa $\mathbf{D}$ considera que a agilidade na tomada de decisão em inovação é um dos principais fatores para o sucesso da empresa. Sem desconsiderar os outros fatores e o próprio processo de desenvolvimento do novo produto, a rapidez na tomada de decisão, garantindo a primazia da introdução de uma novidade no mercado determina duas principais vantagens: em primeiro lugar, a possibilidade de conquistar novos clientes ou mercados interessados no novo produto, vantagem esta tanto maior quanto mais revolucionária for a inovação; em segundo lugar, o fato que durante um certo período, enquanto não surgirem outros produtos equivalentes, não haverá concorrência, possibilitando praticar preços mais altos. As técnicas de análise química existentes hoje em dia, e o empenho da concorrência farão surgir, após algum tempo, produtos similares e a partir desse instante os preços começam a declinar. Consciente dessa questão, a empresa D tem procurado tornar o processo de decisão da inovação o mais ágil possível, sem com isso afetar a sua qualidade.

A decisão estratégica em desenvolvimento de produtos pode, em alguns casos, ser tomada pelos quatro diretores, mas na grande maioria das vezes é tomada pelo diretor técnico.

\section{A decisão estudada}

Para análise da tomada de decisão e por sugestão dos entrevistados, foi considerada a decisão de desenvolver o primeiro produto para tratamento de efluentes e a criação de uma nova área de negócios. Esta decisão foi tomada recentemente.

Durante cerca de três anos, diversas consultas sobre fornecimento de produtos para tratamento de efluentes chegaram à empresa e todas foram declinadas. Este fato não passou desapercebido e a empresa $\mathbf{D}$ começou a cogitar da possibilidade de ingressar neste novo mercado. Coincidentemente, na mesma ocasião, a empresa estava tentando entrar com seus produtos em uma grande indústria e recebeu um desafio para resolver um problema de contaminação do seu efluente. Segundo os diretores da empresa D, essa prática de lançar um desafio para os candidatos a fornecedor, é bastante comum nesse tipo de negócio; é uma forma de testar a capacidade técnica da empresa candidata. Normalmente, esses desafios são problemas complexos que costumam eliminar muitos candidatos.

Desta vez, a empresa D não declinou da consulta e aceitou o desafio. Após algum tempo, conseguiram desenvolver um novo produto que foi testado e aprovado. Hoje, a empresa $\mathbf{D}$ tornou-se o fornecedor exclusivo para esse produto na grande indústria e abriu as portas para o fornecimento de novos produtos.

Cabe observar que não foi feita nenhuma análise de risco. Neste aspecto, a empresa $\mathbf{D}$ considera que o custo financeiro do desenvolvimento é baixo e o risco de falha é 
apenas a perda do tempo da equipe de P\&D, apesar de estimarem em aproximadamente $30 \%$ a freqüência de insucesso dos primeiros testes realizados no cliente.

O quadro 4.8 apresenta a avaliação (do pesquisador) de uma decisão tomada pela empresa D, de acordo com o método proposto por Matheson \& Matheson (1998). Cada quesito foi avaliado com uma nota que pode variar de 1 a 7.

\section{Quadro 4.8 Qualidade da tomada de decisão - empresa D}

\section{Projeto de inovação escolhido}

- Desenvolvimento de um produto para tratamento de efluentes.

- Realizado há cerca de três meses.

\section{Estrutura da decisão}

- A área comercial e se necessário a equipe de P\&D participam da coleta de dados, um ou até quatro diretores decidem.

- Muitas questões são geradas na análise .

- Riscos não são analisados e benefícios superficialmente.

- Avaliação: 6

\section{Alternativas}

- Levantadas várias alternativas.

- São feitas avaliações quantitativas das alternativas (laboratório).

- Não foi definido um plano para implementação da decisão.

- Avaliação: 6

\section{Informações}

- Não foi feita avaliação da probabilidade de sucesso, técnico e de mercado.

- As principais informações foram coletadas.

- não utilizou recursos externos.

- Avaliação: 5

\section{Valores e trade offs}

- Relação entre risco e retorno do desenvolvimento parcialmente conhecida.

- Não avaliado o impacto do desenvolvimento no fluxo de caixa.

- Não avaliado o custo da falha.

- Avaliação: 5

\section{Raciocínio lógico}

- Utiliza alguns métodos quantitativos.

- Aparentemente o desenvolvimento sofreu alterações.

- Avaliação: 4 


\section{Compromisso para ação}

- Os responsáveis pela implementação participam parcialmente da decisão.

- Não houve discordância quanto à decisão.

- Riscos e benefícios não foram divulgados.

- Avaliação: 6

Figura 4.6 Diagrama tipo aranha - empresa D

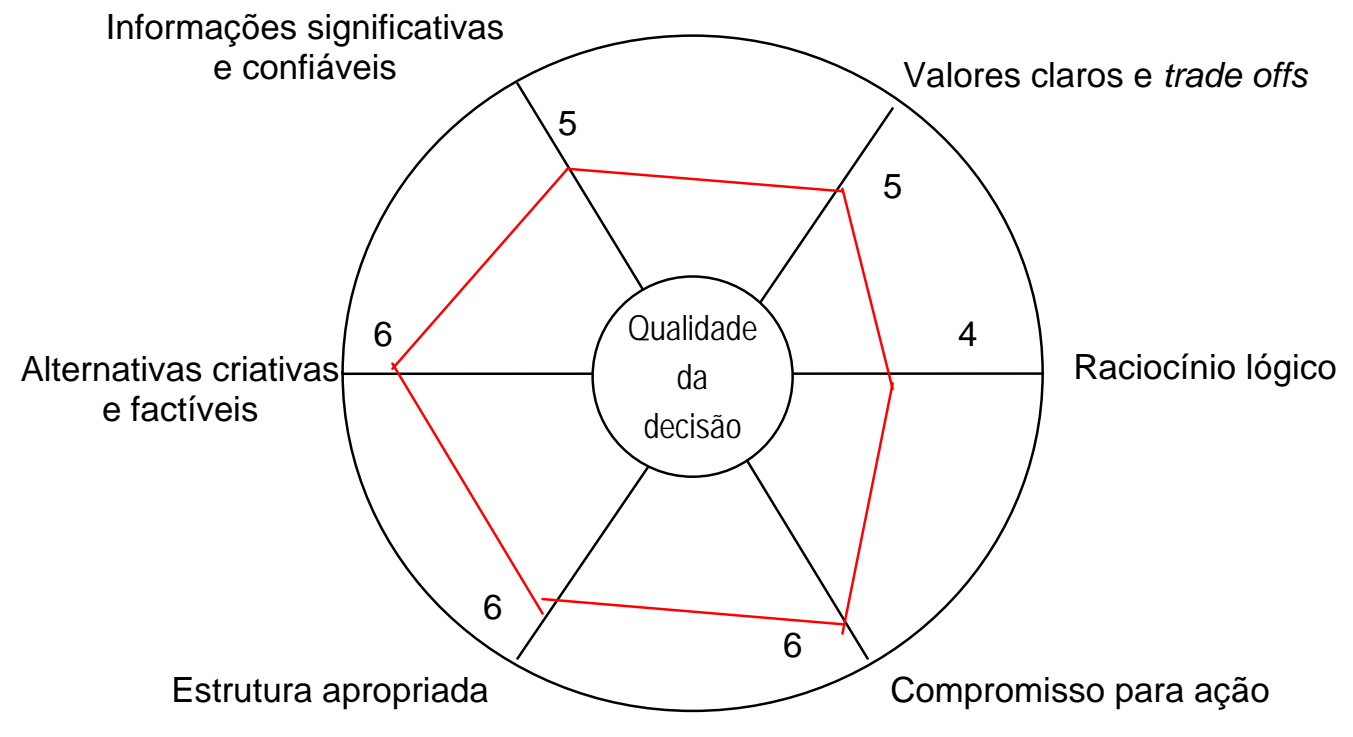

A figura 4.6 ilustra a qualidade da decisão tomada na empresa D. Apenas o quesito raciocínio lógico com $57 \%$ do máximo está em um nível médio, podendo ser melhorado significativamente. Os outros quesitos, com $71 \%$ ou $85 \%$ do máximo estão em um bom nível, havendo pouca coisa a ser feita para melhorá-los. De maneira geral a qualidade da tomada de decisão está homogênea e em bom nível. 


\subsubsection{Percepção e tolerância ao risco na empresa D}

Para avaliar a percepção e tolerância ao risco da empresa $\mathbf{D}$ foram aplicados os dois testes previstos na metodologia com o diretor técnico e o diretor comercial, que representam os principais decisores da empresa em desenvolvimento de produtos.

Os resultados do teste de percepção do risco e tolerância ao risco são apresentados na tabela 4.8 e 4.9 , respectivamente.

Tabela 4.8 Resultado do teste de percepção do risco - empresa D

\begin{tabular}{|c|c|}
\hline Participante & Probabilidade atribuída (\%) \\
\hline a (diretor técnico, acionista) & 80 \\
\hline \hline $\mathrm{b}$ & 50 \\
\hline Média & 65 \\
\hline
\end{tabular}

Tabela 4.9 Resultado do teste de tolerância ao risco - empresa D

\begin{tabular}{|c|c|c|}
\hline Participante & Tolerância (R em R\$) & Tolerância (\% das vendas) \\
\hline $\mathrm{a}$ & 300.000 & 6,3 \\
\hline $\mathrm{b}$ & 300.000 & 6,3 \\
\hline Média & 300.000 & 6,3 \\
\hline
\end{tabular}

A identificação dos decisores $(a, b)$ foi mantida para os dois testes.

Para cálculo da tolerância em \% das vendas, foi considerado como valor das vendas a média dos faturamentos de 1998 e 1999, $R \$ 4,75$ milhões. 


\subsection{Caso IV (empresa E)}

Para coletar os dados da empresa $\mathbf{E}$ foi realizada uma visita à fábrica e três entrevistas, uma com o diretor presidente e proprietário da empresa, uma com o diretor administrativo financeiro e outra com o assistente da diretoria.

A empresa $\mathbf{E}$ é uma pequena indústria de tintas e revestimentos localizada em São Paulo, com um faturamento estimado em R 16 milhões para 1999 e $\mathrm{R} \$ 14$ milhões em 1998. É uma empresa familiar, com 67 funcionários distribuídos em cinco níveis hierárquicos. O processo de produção é simples, em bateladas, constituído basicamente de misturadores. As matérias-primas são todas compradas no mercado nacional embora cerca de $20 \%$ delas tenham origem estrangeira. As operações na produção são quase que totalmente manuais, com pouca utilização de instrumentos de controle. Possui um laboratório onde são feitas as análises de controle da qualidade e os desenvolvimentos de novos produtos.

A empresa $\mathbf{E}$ produz tintas e revestimentos à base de água, exclusivamente para o mercado imobiliário, classificados em três linhas de produtos: uma linha de tintas látex, outra linha de tintas com resinas acrílicas e a linha de revestimentos e massa corrida. $\mathrm{Na}$ linha de tintas látex existem três categorias de produtos: a tinta de melhor qualidade e preço mais alto, que é chamada de produto de primeira linha e mais duas categorias de menor qualidade e preços mais baixo. Na linha de tintas com resinas acrílicas existem apenas duas categorias e em revestimento apenas uma.

A qualidade da tinta, entre outras coisas, está relacionada com a concentração de resina e dióxido de titânio, que por sua vez interfere diretamente no custo de produção. Os principais fatores que determinam a qualidade de uma tinta são: a estabilidade, isto é, o produto não deve apresentar sedimentação ou odores não característicos; a aplicabilidade deve ser tal que proporcione um bom nivelamento da superfície, sem deixar marcas; a durabilidade, isto é, a resistência ao intemperismo natural e finalmente o chamado rendimento/cobertura, que é o volume de tinta necessário para pintar determinada área numa espessura definida.

Tanto a linha de tintas látex, com suas três categorias, como a linha acrílica nas suas duas categorias e os dois tipos de revestimentos decorativos, são fabricados e comercializados em 26 diferentes cores, o que compõe 182 diferentes combinações de produtos.

Os entrevistados não souberam dizer quantos novos produtos foram lançados nos últimos anos, mas estimam que os produtos desenvolvidos nos dois últimos anos sejam responsáveis por algo entre $20 \%$ e $30 \%$ do atual faturamento da empresa. Também não foram capazes de informar quanto se gasta com P\&D e com treinamento, admitindo apenas 
que são valores muito pequenos. A mão-de-obra total, direta e indireta, representa aproximadamente $12 \%$ do custo total do produto.

A empresa E, aparentemente, cresceu durante os seus quinze anos de existência de forma desorganizada, sem se preocupar com controles, registros e informatização. Existe apenas o mínimo necessário para as atividades rotineiras, como vendas e faturamento. As informações gerenciais, em geral, dependem da memória das pessoas, em todas as áreas da empresa; talvez por esta razão sejam pouco confiáveis.

\subsubsection{A historia da empresa $E$}

Há quinze anos, um dos donos de uma empreiteira de serviços de pintura percebeu que poderia fabricar as tintas que utilizava nas suas empreitadas e fundou a empresa $\mathbf{E}$. No início da empresa, a produção de tintas era vendida exclusivamente para a empreiteira, mas com o passar do tempo, conseguiram gradativamente novos mercados e hoje essa venda representa apenas $5 \%$ do total de produtos vendidos. De fato, o grande salto para o mercado se deu há doze anos, quando conseguiram desenvolver uma tinta látex de segunda linha com boa qualidade (para um produto de segunda linha) e comercializada com preço atraente. Nesta ocasião, a empresa começou a se estruturar e um dos filhos do fundador, um jovem com curso de nível médio, assumiu a sua direção, onde está até hoje.

Para adquirir e desenvolver a tecnologia de produção de tintas a empresa $\mathbf{E}$ utilizou e ainda utiliza, basicamente, dois caminhos: a contratação de profissionais especializados e experientes das grandes empresas do ramo que trazem o conhecimento prático necessário, principalmente nas áreas de formulação e vendas; o outro caminho tem sido as informações dos fornecedores de matérias-primas. Estes fornecedores são, em geral, grandes empresas multinacionais que fazem altos investimentos em P\&D e conseguem desenvolver novos aditivos e resinas, precisando difundir os produtos para o mercado.

\subsubsection{O mercado da empresa $E$}

A fabricação de tintas é um dos setores industriais mais antigos que existem. No século dezoito, durante a revolução industrial, surgiram as primeiras indústrias deste segmento na Europa. A partir de 1930 começam a surgir as resinas sintéticas e a indústria de tintas se expande em todo o mundo. A pintura imobiliária à látex é lançada na década de cinqüenta ${ }^{1}$.

O mercado de tintas é dividido conforme o tipo de produto e sua aplicação, assim, é comum o agrupamento em: tintas e vernizes - base solvente; tintas e vernizes - base água; tintas artísticas e educativas; tintas para impressão e outras tintas e vernizes. Este tipo de

\footnotetext{
${ }^{1}$ Informação coletada na WEB, página da Sherwin Williams.
} 
classificação é mais utilizado pelos órgãos do governo, como o sistema Alice de informações da Secretaria de Comércio Exterior do Ministério da Indústria, Comércio e Turismo. Outra forma encontrada é a classificação exclusiva pela aplicação, como por exemplo: tintas e vernizes para construção civil; para indústria em geral, que pode ser subdividida nos diversos tipos de indústria (eletrodomésticos, refrigeradores e outros); para indústria automotiva e para a construção naval.

No Brasil, até 1992, o mercado de tintas imobiliárias era fortemente dominado por cinco ou seis grandes empresas multinacionais. Isto se devia ao fato de que as pequenas empresas não tinham acesso ao dióxido de titânio em condições competitivas. Com a abertura do mercado para importação de matérias-primas ocorrida nesta época, os pequenos puderam competir em melhores condições e conseguiram conquistar uma parcela do mercado, em geral, com produtos de segunda linha e praticando preços inferiores. Cerca de uma dúzia de pequenas empresas cresceram e se tornaram médias ${ }^{2}$, enquanto surgiam centenas de novas pequenas indústrias. Segundo estimativa da empresa E, existem hoje atuando no mercado de tintas imobiliárias, cerca de 5 ou 6 grandes empresas multinacionais, 12 médias e por volta de 400 pequenas fábricas.

A tabela 4.10 apresenta o consumo de tintas e vernizes no Brasil durante os últimos anos.

Tabela 4.10 Mercado de tintas e vernizes - Brasil (em milhões de litros)

\begin{tabular}{|c|c|c|c|c|c|}
\hline SETORES & 1994 & 1995 & 1996 & 1997 & 1998 \\
\hline Imobiliária & 542 & 557 & 583 & $\begin{array}{c}627 \\
(1.122)\end{array}$ & 608 \\
\hline Repintura automotiva & 37 & 37 & 38 & $\begin{array}{c}40 \\
(221)\end{array}$ & 33 \\
\hline Indústria automotiva & 26 & 28 & 31 & $\begin{array}{c}34 \\
(158)\end{array}$ & 27 \\
\hline Indústria geral & 101 & 116 & 123 & $\begin{array}{l}127 \\
(498)\end{array}$ & 114 \\
\hline Total & 706 & 738 & 775 & $\begin{array}{c}828 \\
(1.999)\end{array}$ & 782 \\
\hline
\end{tabular}

2 Empresas médias segundo a empresa E, significam fabricantes com mais de 50 funcionários e faturamento superior a $\mathrm{R} \$ 10$ milhões. Este critério de classificação é particular desta empresa. 
Como pode ser visto na tabela 4.10, o segmento de tintas imobiliárias é de longe o maior deste mercado e onde está concentrada a grande maioria das pequenas indústrias. Por outro lado, o preço médio em 1997 no setor imobiliário foi US\$1,79 por litro, enquanto os outros estão na faixa de US\$ 4,00 a US\$ 5,00 por litro.

O segmento de tintas imobiliárias é o de menor complexidade tecnológica, tanto na produção da tinta como na sua aplicação. Entre as tintas e vernizes da linha imobiliária, a tinta látex à base de água, que é o principal produto da empresa E, é o mais simples do ponto de vista de tecnologia de fabricação e também um dos mais consumidos e de menor preço.

Uma das maiores dificuldades dos pequenos fabricantes de tintas é encontrar um canal de distribuição eficiente e adequado às suas necessidades comerciais. Basicamente, os canais utilizados neste mercado são: lojas especializadas em comércio de tintas, lojas de materiais de construção (pequenas, médias e os grandes magazines), empreiteiras de serviço de pintura e as construtoras. As lojas de materiais de construção, incluindo-se os grandes magazines, preferem trabalhar com as marcas conhecidas do grande público, consideradas de primeira linha, que são aquelas pertencentes às grandes empresas que podem realizar altos investimentos em publicidade. Nas lojas especializadas em tintas, a predominância também é das grandes marcas, mas como este tipo de loja tem maior espaço disponível acaba cedendo uma parte deste espaço para os pequenos fabricantes. As empreiteiras de pintura e as construtoras são canais direto entre fabricante e consumidor final que consomem grandes quantidades de tintas. Este canal é dominado pelas grandes empresas.

A empresa E realiza $80 \%$ de suas vendas através das lojas especializadas, $5 \%$ para a empreiteira da família e 15\% através de pequenas lojas de materiais de construção e construtoras.

\subsubsection{A administração da inovação na empresa $E$}

Assim como, em alguns setores industriais a inovação é parte inerente do negócio, como nas indústrias químicas de especialidades, na pequena indústria de tintas, aparentemente, ocorre o inverso. A inovação é considerada um custo que se possível deve ser evitado. Pelo menos é essa a impressão deixada pela empresa E, uma pequena fabricante de tintas há 15 anos no mercado e com relativo sucesso.

A estratégia declarada da empresa $\mathbf{E}$ em relação às inovações é, na medida do possível, acompanhar as tendências do mercado imitando os outros fabricantes, em geral, as empresas de maior porte. A cada três meses, fazem uma pesquisa de mercado sobre a qualidade do produto dos principais concorrentes. Para realizar esta pesquisa compram latas de tinta da concorrência nas lojas e analisam em seu laboratório. Este método de 
pesquisa permite inicialmente detectar se houve mudanças na composição química das amostras de tinta coletadas. Caso seja encontrada alguma alteração no produto, uma análise mais profunda é realizada, buscando descobrir o tipo de alteração e seus efeitos.

As idéias de inovação na empresa E, normalmente, surgem da observação feita sobre os produtos de concorrentes, seja a observação analítica do laboratório ou a visual dos vendedores nas lojas.

A empreiteira de pintura da família, quando necessário, tem sido usada como um laboratório de teste dos novos produtos desenvolvidos pela empresa. Este recurso é bastante interessante, uma vez que neste tipo de desenvolvimento o desempenho na aplicação do produto é fundamental para a sua aceitação no mercado. Em última instância, os pintores é que definem se um novo produto vai ser aceito ou não pelo mercado, pois a tinta, na grande maioria dos serviços de pintura, é especificada pelo pintor e não pelo dono do imóvel.

A forma utilizada pela empresa E para se atualizar sobre novas tecnologias é unicamente o contato com seus fornecedores. Não tem nenhum tipo de acordo com qualquer instituto de pesquisa, não participa de congressos, não consulta bibliografias especializadas nem possibilita treinamentos aos seus funcionários.

O quadro 4.9 apresenta um resumo dos principais dados referentes ao processo de inovação na empresa E, conforme a declaração dos entrevistados, isto é, de acordo com o ponto de vista da empresa.

\section{Quadro 4.9 Resumo dos dados sobre inovação - empresa E}

1) Objetivo maior da empresa

- Crescer, ampliando a linha de produtos (produzir todos os tipos de produto para a linha imobiliária).

2) Relação das inovações com objetivo

- Os novos produtos são necessários para crescer.

3) Importância dos novos produtos/processo

- Em geral, a importância é baixa.

(continua) 
4) Posição da empresa em relação aos concorrentes

- Pouco inovadora.

5) Visão sobre o setor que atua

- Pouco inovador. Para a direção da empresa o setor faz apenas maquiagem de produtos, isto é, os mesmos produtos são relançados com novas embalagens.

6) Por que decidiu inovar

a) Para acompanhar o mercado.

a1) Sobrevivência da empresa.

b) O que fez a empresa tomar essa decisão

- Concorrentes.

- Observação do mercado.

c) Maiores dificuldades

- Conseguir desenvolver a formulação adequada.

d) Benefícios para a empresa

- Possibilidade de aumentar a receita e reduzir os custos.

\subsubsection{A tomada de decisão na empresa $E$}

As fontes geradoras de inovação, em geral, são os vendedores e a empreiteira de pintura da família através dos contatos com engenheiros e arquitetos de construtoras. Estas idéias de novos produtos são discutidas na área técnica e comercial da empresa até seu amadurecimento. Nesta fase, eventualmente, podem ser feitas algumas análises no laboratório com produtos similares da concorrência. As informações dos fornecedores de matérias-primas servem para auxiliar na descoberta das formulações usadas pela concorrência e eventualmente no desenvolvimento de uma nova formulação.

A decisão em inovação, formalmente, é tomada pelo diretor presidente da empresa com a participação do assistente da diretoria e do diretor administrativo/ financeiro, mas aparentemente, essa decisão é fortemente influenciada pelo assistente da diretoria e nos casos que envolve mais recursos também pelo diretor administrativo/ financeiro. O papel do diretor presidente, ao que tudo indica, é mais de homologação do que de tomada de decisão. 


\section{A decisão estudada}

Para análise da tomada de decisão e por sugestão dos entrevistados, foi considerado a decisão de desenvolver os dois tipos de revestimentos decorativos.

Esse produto surgiu no mercado há alguns anos, introduzido pelas multinacionais. O produto é uma massa, aplicada com desempenadeira que substitui a tinta convencional e possibilita um acabamento com diferentes texturas. Este produto pode ser aplicado nas paredes internas e externas de uma edificação. O aspecto diferente e inédito do acabamento agradou os consumidores e fez o mercado crescer, atraindo novos fabricantes, entre eles a empresa $\mathbf{E}$.

Para não perder espaço nas lojas especializadas e acompanhar a concorrência, a empresa $\mathbf{E}$ tomou a decisão de desenvolver o novo produto. Esta decisão foi tomada após várias conversas entre a direção e a equipe de vendas.

Uma vez decidido desenvolver um revestimento decorativo similar ao existente no mercado, o próximo passo, naturalmente, foi coletar amostras desse produto no mercado e analisá-los no laboratório. Após algumas semanas conseguiram reproduzir uma formulação, aparentemente similar ao produto existente no mercado e começaram a fase de testes. Durante várias semanas testaram diferentes formulações procurando a de melhor desempenho. Nessa fase de testes, a empreiteira de pinturas foi o laboratório de aplicação do desenvolvimento desse produto. Após sete a oito meses da decisão de desenvolver o novo produto, consideraram uma formulação aprovada e passaram aos preparativos de lançamento do produto, que ocorreu algumas semanas mais tarde.

O quadro 4.10 apresenta a avaliação (do pesquisador) de uma decisão tomada pela empresa E, de acordo com o método proposto por Matheson \& Matheson (1998). Cada quesito foi avaliado com uma nota que pode variar de 1 a 7.

\section{Quadro 4.10 Qualidade da tomada de decisão - empresa E}

\section{Projeto de inovação escolhido}

- Desenvolvimento de um produto para revestimento decorativo.

- Realizado há cerca de um ano.

\section{Estrutura da decisão}

- Não existe uma estrutura de decisão definida, em geral, diversas áreas opinam e a direção decide.

- Apenas as questões levantadas pelos vendedores e testes são analisadas.

- Riscos não são analisados e benefícios superficialmente.

- Avaliação: 3

\section{Alternativas}

- Levantadas várias alternativas de formulação, mas não de desenvolvimento.

- São feitas algumas avaliações quantitativas das alternativas (laboratório).

- Não foi definido um plano para implementação da decisão.

- Avaliação: 3 


\section{Informações}

- Não foi feita avaliação da probabilidade de sucesso, técnico e de mercado.

- Poucas informações foram coletadas.

- não utilizou recursos externos.

- Avaliação: 4

\section{Valores e trade offs}

- Relação entre risco e retorno do desenvolvimento desconhecida.

- Não avaliado o impacto do desenvolvimento no fluxo de caixa.

- Não avaliado o custo da falha.

- Avaliação: 2

\section{Raciocínio lógico}

- Não utiliza métodos quantitativos.

- Aparentemente o desenvolvimento sofreu alterações.

- Avaliação: 4

\section{Compromisso para ação}

- Os responsáveis pela implementação participam parcialmente da decisão.

- Não houve discordância quanto à decisão.

- Riscos e benefícios não foram divulgados.

- Avaliação: 5

\section{Figura 4.7 Diagrama tipo aranha - empresa E}

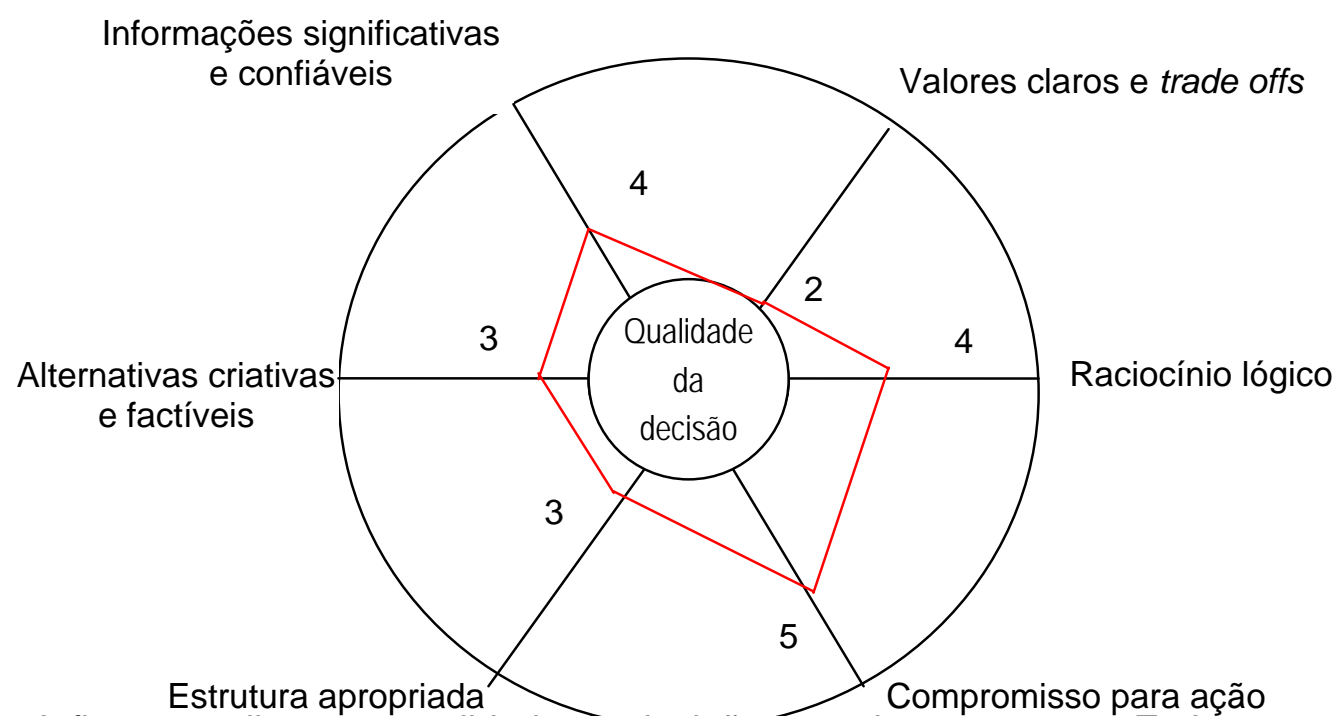

A figura 4.7 ilustra a qualidade da cteeisão tomada na empresa $\mathbf{E}$. Apenas o quesito compromisso para ação com $71 \%$ do máximo está em um nível bom, podendo ser melhorado pouca coisa. Os quesitos raciocínio lógico e informações estão razoáveis, com $57 \%$ do máximo, podendo ser significativamente melhorados. Os outros quesitos, com 43\% 
ou $29 \%$ do máximo estão em um nível muito baixo. De maneira geral, a qualidade da tomada de decisão não está homogênea e com baixo nível.

\subsubsection{Percepção e tolerância ao risco na empresa E}

Para avaliar a percepção e tolerância ao risco da empresa $\mathbf{E}$ foram aplicados os dois testes previstos na metodologia com o diretor presidente, o assistente da diretoria e o diretor administrativo/financeiro, que representam os principais decisores da empresa em desenvolvimento de produtos.

Os resultados do teste de percepção do risco e tolerância ao risco são apresentados na tabela 4.11 e 4.12 , respectivamente.

Tabela 4.11 Resultado do teste de percepção do risco - empresa E

\begin{tabular}{|c|c|}
\hline Participante & Probabilidade atribuída (\%) \\
\hline a (diretor-presidente) & 50 \\
\hline b & 20 \\
\hline c & 40 \\
\hline \hline Média & 36,7 \\
\hline
\end{tabular}

Tabela 4.12 Resultado do teste de tolerância ao risco - empresa E

\begin{tabular}{|c|c|c|}
\hline Participante & Tolerância (R em R\$) & Tolerância (\% das vendas) \\
\hline a & 700.000 & 4,7 \\
\hline b & ND & ND \\
\hline c & ND & ND \\
\hline Média & 700.000 & 4,7 \\
\hline
\end{tabular}

A identificação dos decisores ( $a, b, c)$ foi mantida para os dois testes.

ND significa que os decisores b e c não declararam um valor para o teste.

Para cálculo da tolerância em \% das vendas foi considerado como valor das vendas a média dos faturamentos de 1998 e 1999, R\$ 15 milhões. 


\section{CAPÍTULO 5}

\section{ANÁLISE COMPARATIVA DOS CASOS}

A estratégia desta análise comparativa foi definida levando-se em conta o objetivo maior deste estudo, contido nas duas questões de pesquisa: por que e como estas empresas tomam a decisão de desenvolver novos produtos e processos. Junto com as questões de pesquisa foram analisadas as variáveis principais da proposição do estudo: a percepção e a tolerância ao risco.

A análise comparativa das cinco empresas foi subdividida nos seguintes itens:

1) Negócio e administração geral;

2) Administração da inovação;

3) Processo de tomada de decisão;

4) Percepção e tolerância ao risco.

A análise está baseada nas informações obtidas durante as diversas entrevistas e no resultado dos testes realizados com os principais dirigentes de cada empresa participante.

Considerando-se o caráter exploratório deste trabalho, os dados numéricos coletados foram tratados como complemento do estudo, sem qualquer caráter quantitativo.

\subsection{Análise do negócio e administração geral}

Todas as empresas estudadas são indústrias de pequeno porte que atuam no setor químico há pelo menos sete anos.

\section{O produto}

As empresas C e D produzem especialidades químicas que são produtos, em geral, auxiliares na produção de terceiros, isto é, não são incorporados a outros produtos como matéria-prima. As especialidades químicas abrangem uma gama muito grande de produtos, na forma de líquidos, pós ou pastas e com as mais diversas aplicações. A empresa A começou como uma produtora de especialidades, mas preferiu se especializar e se concentrar em biocidas, um tipo de especialidade que incorpora mais tecnologia que a maior parte das outras especialidades.

A empresa B produz formol e resina de uréia formol. Estes produtos são commodities ou produtos básicos, que são incorporados a outros produtos como matéria- 
prima. A empresa $\mathbf{E}$ atua em um mercado totalmente diferente das outras quatro empresas estudadas. O seu produto, tintas e revestimentos imobiliários, destina-se ao consumidor final.

\section{O mercado}

As empresas C e D são as únicas que estão no mesmo tipo de negócio e podem portanto ser consideradas concorrentes em alguns segmentos do mercado em que atuam. O mercado de especialidades químicas é muito diversificado quanto ao tipo de negócio e porte das empresas. As duas empresas procuram atender prioritariamente às grandes indústrias. É um mercado que pode ser considerado médio e tem permanecido estável nos últimos anos. As empresas que atuam nesse mercado, em geral, são de porte médio ou pequeno. As poucas empresas grandes que estão nesse negócio, não possuem participação no mercado suficiente para torná-lo concentrado. Os produtos são vendidos pela capacidade de resolver os problemas do cliente e não pelo seu conteúdo. Os preços praticados são altos, quando o produto é inédito e tendem a cair rapidamente, quando os concorrentes lançam os produtos similares. Existe uma constante disputa entre os fabricantes para melhorar o desempenho dos produtos.

O mercado de biocidas (empresa $\mathbf{A}$ ) é relativamente pequeno, mas está nitidamente em expansão, oferecendo novas oportunidades de negócio. Este mercado é uma pequena parte do mercado de especialidades. Os principais clientes são as grandes indústrias, de diversos setores. Assim como o mercado de especialidades, está voltado principalmente para o desempenho do produto e assistência técnica. Entretanto, a competição é menos intensiva, o que implica em preços mais estáveis e produtos com vida mais longa. Aparentemente, o mercado é concentrado, com a significativa participação de algumas multinacionais.

O mercado de fenol e resinas de uréia formol (empresa B) é concentrado e dominado pelas grandes e médias empresas. Tanto os principais clientes, como os concorrentes da empresa B, são grandes indústrias. Este mercado, apesar de grande tem permanecido estável nos últimos anos, com alguma perspectiva de crescimento para o futuro. Devido às características do negócio (produto de baixa margem de lucro, altos volumes e sensível ao custo de transporte) é praticamente impossível a exportação. Isso pode representar uma desvantagem, mas também a segurança de que não existirá concorrência de produtos importados. A competição é fortemente centrada em preço e a cada dia com especificações do produto mais exigentes na qualidade. A direção da empresa B, aparentemente, conhece as características do seu negócio e vem procurando melhorar o desempenho do processo de produção. O fato de uma pequena empresa estar participando deste mercado, aparentemente, é uma situação contingente. Ao que tudo indica, para 
permanecer neste mercado a empresa B deverá buscar um crescimento acelerado e deixar de ser uma pequena indústria em poucos anos.

No mercado de tintas e revestimentos (empresa E), a participação das pequenas empresas fica quase que totalmente restrita aos produtos considerados como de segunda linha. As grandes empresas realizam altos investimentos em publicidade e controlam boa parte dos canais de distribuição, principalmente aqueles que absorvem grandes quantidades, como as construtoras e as grandes lojas de materiais de construção. Os principais clientes da empresa E são as lojas especializadas em tintas imobiliárias. Em geral, estas lojas são de pequeno ou médio porte e precisam do produto de segunda linha para atender os consumidores de poder aquisitivo menor.

\section{A tecnologia}

A tecnologia empregada para desenvolver e produzir especialidades químicas pode ser caracterizada como embutida no produto, no sentido de que é possível se conseguir o acesso à formulação do produto por meio de análise de laboratório. Por outro lado, quando se trata do desenvolvimento de um novo produto, ainda não existente no mercado, os conhecimentos necessários não se encontram disponíveis em base documental estruturada. Assim, a tecnologia pode ser considerada como incorporada nas pessoas. Em outras palavras, o domínio da tecnologia de especialidades químicas (desenvolvimento de produtos inéditos) é complexo e difícil, enquanto a imitação é relativamente fácil de ser conseguida.

As empresas A e D, aparentemente, são as que estão mais capacitadas para lançar produtos inéditos no mercado, desenvolvidos a partir do conhecimento existente na empresa. As duas empresas utilizam fontes semelhantes para adquirir tecnologia: a literatura especializada, os fornecedores, o contato com Universidades e a participação em congressos. A empresa $\mathbf{C}$ prefere adquirir de terceiros a tecnologia para produtos inéditos no mercado brasileiro e manter apenas o conhecimento para desenvolver pequenas adaptações. Nesse sentido, a sua principal fonte de tecnologia tem sido as empresas estrangeiras.

A empresa $\mathbf{E}$ utiliza as informações de fornecedores e a análise dos produtos de concorrentes como fontes de tecnologia. Não faz parte dos seus planos o lançamento de produto inédito.

A empresa $\mathbf{B}$ representa um caso à parte, na medida em que a sua tecnologia está voltada para o processo de produção. A sua equipe técnica se restringe ao desenvolvimento de pequenas melhorias do processo e eventuais adaptações do produto às exigências dos clientes. As grandes alterações do processo, como a inovação na qual se estudou a tomada de decisão, são desenvolvidas com o suporte de empresas de engenharia. 
As principais características do negócio de cada empresa, quanto ao produto, mercado e tecnologia, são apresentadas no quadro 5.1.

\section{Quadro 5.1 Características do negócio das empresas}

\begin{tabular}{|c|c|c|c|c|c|}
\hline & Empresa A & Empresa B & Empresa C & Empresa D & Empresa E \\
\hline Negócio principal & Biocidas & $\begin{array}{l}\text { Formol e resina } \\
\text { de uréia formol }\end{array}$ & Especialidades & Especialidades & $\begin{array}{l}\text { Tintas } \\
\text { imobiliárias }\end{array}$ \\
\hline Principais clientes & $\begin{array}{l}\text { Grandes } \\
\text { indústrias }\end{array}$ & $\begin{array}{l}\text { Grandes } \\
\text { indústrias }\end{array}$ & $\begin{array}{l}\text { Grandes } \\
\text { indústrias }\end{array}$ & $\begin{array}{l}\text { Grandes } \\
\text { indústrias } \\
\end{array}$ & $\begin{array}{l}\text { Lojas de } \\
\text { tintas }\end{array}$ \\
\hline Principais concorrentes & $\begin{array}{l}\text { Grandes } \\
\text { indústrias }\end{array}$ & $\begin{array}{l}\text { Grandes } \\
\text { indústrias }\end{array}$ & $\begin{array}{l}\text { Médias e } \\
\text { pequenas }\end{array}$ & $\begin{array}{l}\text { Médias e } \\
\text { pequenas }\end{array}$ & $\begin{array}{l}\text { Grandes } \\
\text { indústrias }\end{array}$ \\
\hline \multirow{3}{*}{$\begin{array}{c}\underline{\text { Mercado }} \text { (tamanho) } \\
\text { (foco) }\end{array}$} & $\begin{array}{l}\text { - Pequeno, em } \\
\text { expansão }\end{array}$ & $\begin{array}{l}\text { - Grande e } \\
\text { estável }\end{array}$ & $\begin{array}{l}\text { - Médio e } \\
\text { estável }\end{array}$ & $\begin{array}{l}\text { - Médio e } \\
\text { estável }\end{array}$ & $\begin{array}{l}\text { - Grande, em } \\
\text { expansão }\end{array}$ \\
\hline & $\begin{array}{l}\text { - Voltado para } \\
\text { desempenho } \\
\text { do produto e } \\
\text { assistência } \\
\text { técnica }\end{array}$ & $\begin{array}{l}\text { - Voltado para } \\
\text { preço e } \\
\text { qualidade } \\
\text { do produto }\end{array}$ & $\begin{array}{l}\text { - Voltado para } \\
\text { solução de } \\
\text { problemas e } \\
\text { assistência } \\
\text { técnica }\end{array}$ & $\begin{array}{l}\text { - Voltado para } \\
\text { solução de } \\
\text { problemas e } \\
\text { assistência } \\
\text { técnica }\end{array}$ & $\begin{array}{l}\text { - Voltado para } \\
\text { preço e } \\
\text { sensível à } \\
\text { publicidade }\end{array}$ \\
\hline & $\begin{array}{l}\text { - Concentrado, } \\
\text { com algumas } \\
\text { multinacionais }\end{array}$ & $\begin{array}{l}\text { - Concentrado, } \\
\text { com algumas } \\
\text { multinacionais }\end{array}$ & $\begin{array}{l}\text { - Não } \\
\text { concentrado, } \\
\text { com pequenas } \\
\text { e médias } \\
\end{array}$ & $\begin{array}{l}\text { - Não } \\
\text { concentrado, } \\
\text { com pequenas } \\
\text { e médias } \\
\end{array}$ & $\begin{array}{c}\text { - Concentrado, } \\
\text { com algumas } \\
\text { multinacionais }\end{array}$ \\
\hline$\underline{\text { Tecnologia (foco) }}$ & $\begin{array}{l}\text { - Na formulação } \\
\text { e aplicação } \\
\text { do produto }\end{array}$ & $\begin{array}{l}\text { - No processo } \\
\text { de produção }\end{array}$ & $\begin{array}{l}\text { - Na formulação } \\
\text { e aplicação } \\
\text { do produto }\end{array}$ & $\begin{array}{l}\text { - Na formulação } \\
\text { e aplicação } \\
\text { do produto }\end{array}$ & $\begin{array}{l}\text { - Na } \\
\text { formulação } \\
\text { do produto }\end{array}$ \\
\hline (desenvolvimento) & - Recente & - Há vários anos & - Recente & - Recente & - Há vários anos \\
\hline (importância p/negócio) & - Grande & - Média & - Grande & - Grande & - Média \\
\hline (disponibilidade) & - Parcial & - Disponível & - Parcial & - Parcial & - Disponível \\
\hline (principais fontes) & $\begin{array}{l}\text { - Fornecedores, } \\
\text { literatura, } \\
\text { institutos de } \\
\text { pesquisa, } \\
\text { congressos, } \\
\text { acordo com } \\
\text { empresa inglesa }\end{array}$ & $\begin{array}{l}\text { - Empresa de } \\
\text { consultoria } \\
\text { em } \\
\text { engenharia }\end{array}$ & $\begin{array}{l}\text { - Fornecedores, } \\
\text { acordos e } \\
\text { compra de } \\
\text { formulação } \\
\text { de empresas } \\
\text { estrangeiras }\end{array}$ & $\begin{array}{l}\text { - Fornecedores, } \\
\text { literatura, } \\
\text { congressos }\end{array}$ & $\begin{array}{l}\text { - Fornecedores, } \\
\text { análise do } \\
\text { produto da } \\
\text { concorrência }\end{array}$ \\
\hline
\end{tabular}

A situação geral das cinco empresas e as principais características da administração de seus negócios são: 


\section{- Empresa A}

Aparentemente, a empresa A é a que está melhor posicionada para competir no negócio do qual participa. A direção da empresa tem consciência da importância da tecnologia para o seu negócio e vem investindo no desenvolvimento da sua capacitação através de treinamento, ampliação do laboratório, participação em congressos, contatos com Universidades e outras formas. Possui uma fábrica com instalações modernas e uma organização administrada profissionalmente, com poucos funcionários e apenas três níveis hierárquicos. A sua administração está enfocada nos aspectos estratégicos para o negócio, delegando a terceiros as atividades consideradas menos importantes. A relação faturamento anual por funcionário em 1999, deverá ser de $\mathrm{R} \$ 350.000,00$ / funcionário. Sua produção é simples, flexível e pouco verticalizada. Existe uma grande preocupação com a qualidade do produto; possui certificado ISO 9002. Apresentou nos sete anos de existência um faturamento significativamente crescente.

\section{- Empresa B}

Em contrapartida, a empresa $\mathbf{B}$ é uma das que está com mais dificuldades para se posicionar no seu negócio. Praticamente não investiu em tecnologia durante vários anos, restringindo-se às pequenas melhorias do processo e adaptações do produto para o cliente. Possui uma fábrica com instalações antigas e uma organização administrada profissionalmente, com relativamente poucos funcionários e quatro níveis hierárquicos. Nota-se claramente que a empresa está passando por uma fase de transição entre a administração anterior, familiar, e a atual, profissional. A nova direção da empresa está voltada para o enfoque dos aspectos estratégicos do negócio, adotando a política de transferir para terceiros as atividades consideradas secundárias. A relação faturamento anual por funcionário, previsto para 1999 é de $R$ \$ 340.000,00 / funcionário. Seu processo de produção é complexo e obsoleto. Não foi observado a existência de preocupação com qualidade, de maneira geral, e muito menos em relação ao produto. Apresentou nos últimos anos antes da nova direção, um constante decréscimo do faturamento. Em 1999, espera-se um resultado muito melhor e um contínuo crescimento no futuro.

\section{- Empresa C}

A empresa $\mathbf{C}$, assim como a empresa $\mathbf{B}$, enfrenta atualmente alguns problemas de posicionamento no seu negócio. É a empresa mais antiga das cinco, com mais de trinta anos de existência. Aparentemente a empresa cresceu de forma 
desordenada, sem estabelecer uma estratégia, procurando atender diversos segmentos do mercado. A direção da empresa, após dois anos de leve queda no faturamento, esboçou uma reestruturação da organização, reduzindo o número de funcionários e a linha de produtos. A sua filosofia de desenvolvimento tecnológico tem sido baseada na contratação externa de formulação para os produtos inexistentes no mercado nacional, seja através de acordos e contratos com empresas do exterior ou contratação temporária de especialistas, e o desenvolvimento próprio para adaptações de produtos. Possui uma fábrica bastante ampla, com instalações antiquadas e uma organização tradicional, com muitos funcionários. Sua administração é tipicamente familiar. A relação faturamento anual por funcionário em 1999, deverá ser de aproximadamente R\$ 73.000,00/ funcionário. Sua produção é simples, mas razoavelmente verticalizada. Existe alguma preocupação com qualidade, pouco consistente: um programa que vinha sendo desenvolvido para implantar um sistema de qualidade foi interrompido em 1999. Apresentou uma queda do faturamento nos últimos anos.

\section{- Empresa D}

É a empresa mais nova das cinco estudadas e provavelmente a melhor estruturada. Os quatro diretores e proprietários da empresa conhecem profundamente o negócio, pois durante vários anos, antes de fundarem a empresa $\mathbf{D}$, atuaram nesse mesmo negócio trabalhando em uma multinacional. A direção da empresa conhece a importância da tecnologia para seu negócio e a necessidade de constante atualização, procurando agir de acordo com esse conhecimento. A empresa mantém contatos com universidades (UNICAMP e USP), mas não firmou acordo com nenhuma instituição de pesquisa. Possui uma fábrica com instalações modernas e uma organização bastante enxuta, administrada profissionalmente, com poucos funcionários e apenas três níveis hierárquicos. Sua produção é simples, muito flexível e sem nenhuma verticalização, o que faz parte, explicitamente, da filosofia da empresa. A relação faturamento anual por funcionário em 1999, deverá ser de R\$ 183.000,00 / funcionário. Existe uma grande preocupação com a qualidade do produto: um sistema da qualidade vem sendo implantado para obtenção da certificação ISO 9000. Apresentou durante os sete anos de existência um constante aumento do faturamento.

\section{- Empresa E}


A direção da empresa conhece as características do mercado e praticamente não investe em novas tecnologias, tanto para o produto, como para o processo; a sua estratégia é declaradamente de imitar os líderes do mercado. Possui uma fábrica com instalações antigas e uma organização, aparentemente, tradicional, com cinco níveis hierárquicos. A sua administração é familiar e, aparentemente, pouco interessada no desenvolvimento de seus recursos humanos. A relação faturamento anual por funcionário em 1999, deverá ser de $\mathrm{R} \$ 239.000,00$ / funcionário. Sua produção é simples e pouco verticalizada. Não existe preocupação com a qualidade. Apresentou nos últimos cinco anos flutuações no faturamento

O quadro 5.2 permite uma visão geral das principais características das cinco empresas que participam deste estudo. 


\section{Quadro 5.2 Característica geral das empresas}

\begin{tabular}{|c|c|c|c|c|c|}
\hline & Empresa A & Empresa B & Empresa C & Empresa D & Empresa E \\
\hline Negócio principal & Biocidas & $\begin{array}{l}\text { Formol e resina } \\
\text { de uréia formol }\end{array}$ & $\begin{array}{l}\text { Especiali- } \\
\text { dades }\end{array}$ & $\begin{array}{l}\text { Especiali- } \\
\text { dades }\end{array}$ & $\begin{array}{c}\text { Tintas } \\
\text { imobiliárias }\end{array}$ \\
\hline $\begin{array}{l}\text { No de funcionários e (.) } \\
\text { níveis hierárquicos }\end{array}$ & $20(3)$ & $50(4)$ & $96(4)$ & $30(3)$ & $67(5)$ \\
\hline $\begin{array}{l}\text { Administração } \\
\text { Utilização de terceiros }\end{array}$ & $\begin{array}{c}\text { Profissional } \\
\text { Intensa }\end{array}$ & $\begin{array}{l}\text { Profissional } \\
\text { Média }\end{array}$ & $\begin{array}{l}\text { Familiar } \\
\text { Pouca }\end{array}$ & $\begin{array}{l}\text { Profissional } \\
\text { Intensa }\end{array}$ & $\begin{array}{l}\text { Familiar } \\
\text { Média }\end{array}$ \\
\hline $\begin{array}{l}\text { Faturamento em } 1998 \text { I } \\
1999(\mathrm{R} \$ \text { x 1000) }\end{array}$ & $\begin{array}{l}4.800 / \\
7.000\end{array}$ & $\begin{array}{l}6.000 / \\
17.000\end{array}$ & $\begin{array}{l}7.000 / \\
7.000\end{array}$ & $\begin{array}{c}4.000 / \\
5.500\end{array}$ & $\begin{array}{l}14.000 / \\
16.000\end{array}$ \\
\hline $\begin{array}{l}\text { Faturamento } 1999 \text { I } \\
\text { funcionário (R\$ x 1000) }\end{array}$ & 350 & 340 & 73 & 183 & 239 \\
\hline $\begin{array}{l}\text { Tempo em operação } \\
\text { (anos) }\end{array}$ & 10 & 18 & 32 & 7 & 15 \\
\hline $\begin{array}{l}\text { Mão-de-obra no custo } \\
\text { total do produto (\%) }\end{array}$ & 12 & 8 & 30 & 12 & 12 \\
\hline $\begin{array}{l}\text { Gasto com P\&D em } \\
\% \text { do faturamento }\end{array}$ & 1,5 & Insignificante & 1,0 & 1,0 & $\begin{array}{l}\text { Insignifi- } \\
\text { cante }\end{array}$ \\
\hline $\begin{array}{l}\text { Gasto com treinamento } \\
\text { em } \% \text { do faturamento }\end{array}$ & 1,0 & 0,14 & 2,0 & $\begin{array}{c}5 \% \text { do tempo } \\
\text { na empresa }\end{array}$ & $\begin{array}{l}\text { Insignifi- } \\
\text { cante }\end{array}$ \\
\hline Processo de produção & $\begin{array}{l}\text { Batelada } \\
\text { (simples) }\end{array}$ & $\begin{array}{l}\text { Contínuo } \\
\text { (complexo) }\end{array}$ & $\begin{array}{l}\text { Batelada } \\
\text { (simples) }\end{array}$ & $\begin{array}{l}\text { Batelada } \\
\text { (simples) }\end{array}$ & $\begin{array}{l}\text { Batelada } \\
\text { (simples) }\end{array}$ \\
\hline
\end{tabular}

Nota: A classificação da administração das empresas em familiar e profissional está de acordo com a literatura sobre pequenas empresas, conforme apresentada no item 2.3.1 deste trabalho.

O negócio das empresas A, C e D pode ser caracterizado como intenso em tecnologia, dada a importância que este fator tem para o setor que atuam. As empresas B e E estão em negócios que são intensos em capital, o que, de certa forma não é comum para empresas desse porte. A empresa B, aparentemente, está atravessando uma fase de transição e poderá se tornar uma empresa média em pouco tempo. Quanto à empresa $\mathbf{E}, \mathrm{a}$ sua participação em um setor intenso em capital se deve ao fato de atuar em um nicho específico do mercado (tintas de segunda linha), onde não há necessidade de se investir em publicidade.

A atuação das empresas A e D está voltada para a capacitação dos recursos humanos da empresa e expansão do negócio. A empresa $\mathbf{B}$, com a nova direção, tem atuado no sentido de melhorar o processo de produção. Para a empresa C, o foco principal 
da atuação tem sido a redução da linha de produtos. A empresa $\mathbf{E}$ atua para expandir suas vendas através do lançamento de novos produtos.

Através das entrevistas com os dirigentes foi possível conhecer como as empresas estão sendo administradas quanto à qualidade. Para analisar a visão da direção sobre o valor da qualidade para a empresa foi considerado os seguintes pontos:

1) Quanto a empresa investe no desenvolvimento profissional de seus recursos humanos (treinamento, participação em congressos e outros).

2) Qual a importância de um sistema da qualidade para a empresa.

Com base nestes dois aspectos foi possível observar que as empresas $\mathbf{A}$ e $\mathbf{D}$ são as que mais valorizam a qualidade. A empresa $C$ iniciou em 1998, um programa de treinamento em qualidade, visando a certificação ISO 9000 mas interrompeu o programa em 1999. As empresas B e E não possuem planos para criação de sistema de qualidade e praticamente não investem em desenvolvimento profissional.

O quadro 5.3 apresenta um resumo das principais características do negócio de cada empresa e a atuação destas.

Quadro 5.3 Resumo da atuação e resultado das empresas

\begin{tabular}{|c|c|c|c|c|c|}
\hline & Empresa A & Empresa B & Empresa C & Empresa D & Empresa E \\
\hline Negócio & $\begin{array}{l}\text { Intenso em } \\
\text { tecnologia }\end{array}$ & $\begin{array}{l}\text { Intenso em } \\
\text { capital }\end{array}$ & $\begin{array}{l}\text { Intenso em } \\
\text { tecnologia }\end{array}$ & $\begin{array}{l}\text { Intenso em } \\
\text { tecnologia }\end{array}$ & $\begin{array}{l}\text { Intenso em } \\
\text { capital }\end{array}$ \\
\hline Competição & $\begin{array}{l}\text { Desempenho } \\
\text { do produto e } \\
\text { assistência tec. }\end{array}$ & $\begin{array}{l}\text { Preço do } \\
\text { produto }\end{array}$ & $\begin{array}{l}\text { Solução de } \\
\text { problemas }\end{array}$ & $\begin{array}{l}\text { Solução de } \\
\text { problemas }\end{array}$ & $\begin{array}{l}\text { Preço, } \\
\text { publicidade }\end{array}$ \\
\hline Atuação & $\begin{array}{l}\text { Desenvolv. da } \\
\text { capacitação } \\
\text { tecnológica e } \\
\text { penetração } \\
\text { em novos } \\
\text { mercados }\end{array}$ & $\begin{array}{l}\text { Melhoria do } \\
\text { processo, } \\
\text { redução de } \\
\text { custo, } \\
\text { expansão } \\
\text { das vendas }\end{array}$ & $\begin{array}{l}\text { Redução da } \\
\text { linha de } \\
\text { produtos e } \\
\text { de custo }\end{array}$ & $\begin{array}{l}\text { Desenvolv. da } \\
\text { capacitação } \\
\text { tecnológica e } \\
\text { expansão das } \\
\text { vendas }\end{array}$ & $\begin{array}{l}\text { Aumentar a } \\
\text { linha de } \\
\text { produtos e } \\
\text { expandir as } \\
\text { vendas }\end{array}$ \\
\hline Ênfase em qualidade & $\begin{array}{l}\text { Sim, } \\
\text { possui sistem } \\
\text { certificado ISO }\end{array}$ & $\begin{array}{l}\text { Não } \\
\text { la }\end{array}$ & $\begin{array}{l}\text { Pouca, } \\
\text { começou e parou } \\
\text { implantação } \\
\text { do sistema }\end{array}$ & $\begin{array}{l}\text { Sim, } \\
\text { usistema em } \\
\text { implantação }\end{array}$ & Não \\
\hline \multicolumn{6}{|l|}{ Resultados } \\
\hline $\begin{array}{l}\text { Crescimento do } \\
\text { faturamento } 99 / 98\end{array}$ & $46 \%$ & $183 \%$ & $0 \%$ & $37,5 \%$ & $14 \%$ \\
\hline $\begin{array}{l}\text { Faturamento I } \\
\text { funcionário (99) }\end{array}$ & $\mathrm{R} \$ 350.000$ & $\mathrm{R} \$ 340.000$ & $\mathrm{R} \$ 73.000$ & $\mathrm{R} \$ 183.000$ & $R \$ 238.000$ \\
\hline
\end{tabular}


O ponto de partida para se analisar o processo de administração da inovação em cada empresa foi a visão da própria empresa sobre a importância e participação da inovação no seu negócio. Uma síntese desta visão é apresentada no quadro 5.4.

\section{Quadro 5.4 Visão das empresas sobre a importância da inovação}

\begin{tabular}{|c|c|c|c|c|c|}
\hline & EMPRESA A & EMPRESA B & EMPRESA C & EMPRESA D & EMPRESA E \\
\hline $\begin{array}{l}\text { Importância da } \\
\text { inovação para } \\
\text { a empresa }\end{array}$ & $\begin{array}{l}\text { - Alta } \\
\text { - Manter } \\
\text { crescimento }\end{array}$ & $\begin{array}{l}\text { - Alta } \\
\text { - Vital para a } \\
\text { sobrevivência } \\
\text { no longo prazo }\end{array}$ & $\begin{array}{l}\text { - Alta } \\
\text { - Vital para a } \\
\text { sobrevivência, } \\
\text { faz parte do } \\
\text { negócio }\end{array}$ & $\begin{array}{l}\text { - Alta } \\
\text { - Negócio } \\
\text { baseado em } \\
\text { novidades }\end{array}$ & - Baixa \\
\hline $\begin{array}{l}\text { Visão da atuação } \\
\text { em relação aos } \\
\text { concorrentes }\end{array}$ & $\begin{array}{l}\text { - Entre } \\
\text { inovadora e } \\
\text { muito } \\
\text { inovadora }\end{array}$ & $\begin{array}{l}\text { - Muito } \\
\text { inovadora }\end{array}$ & $\begin{array}{l}\text { - Muito } \\
\text { inovadora }\end{array}$ & $\begin{array}{l}\text { - Muito } \\
\text { inovadora }\end{array}$ & $\begin{array}{l}\text { Pouco } \\
\text { inovadora }\end{array}$ \\
\hline $\begin{array}{l}\text { Visão sobre o } \\
\text { setor que atua }\end{array}$ & $\begin{array}{l}\text { - Neutro } \\
\text { - Mudando para } \\
\text { inovador }\end{array}$ & $\begin{array}{l}\text { - Neutro } \\
\text { - Pequena } \\
\text { pressão }\end{array}$ & $\begin{array}{l}\text { - Muito } \\
\text { inovador }\end{array}$ & $\begin{array}{l}\text { - Muito } \\
\text { inovador }\end{array}$ & $\begin{array}{l}\text { - Pouco inovador } \\
\text { - Faz } \\
\text { "maquiagem" }\end{array}$ \\
\hline
\end{tabular}

Exceto a empresa E, que considera pouco importante a inovação, as outras quatro empresas lhe atribuem grande importância. As empresas C e D, que atuam no mercado de especialidades, têm plena consciência do importante papel que a inovação representa para esse tipo de negócio e possuem a mesma visão sobre o próprio desempenho e sobre o setor de especialidades. A empresa A também considera a inovação como um fator importante do seu negócio, vendo nela a possibilidade de crescimento da empresa. Diferente das empresas C e D, não considera o setor de biocidas (que é um tipo de especialidade química) inovador. Para a empresa B, a inovação do processo é vital para o seu futuro, embora considere o seu setor como neutro ou que exerce pouca pressão para inovar. Na verdade, a pressão para inovar o seu processo vem da necessidade de reduzir os custos e aumentar sua capacidade produtiva.

A importância da inovação para as empresas também pode ser analisada através de indicadores, tais como, o número de novos produtos desenvolvidos em um determinado período e o quanto esses produtos representam na receita da empresa. Apesar da dificuldade em se obter informações deste tipo em pequenas empresas, o quadro 5.5 apresenta um resumo dos dados obtidos. 
Quadro 5.5 Indicadores da importância da inovação

\begin{tabular}{|l|c|c|c|c|c|}
\hline & EMPRESA A & EMPRESA B & EMPRESA C & EMPRESA D & EMPRESA E \\
\hline $\begin{array}{l}\text { Linha de } \\
\text { produtos } \\
\text { atual }\end{array}$ & 29 & 10 & $\begin{array}{c}\sim 250 \text { em 1999 } \\
\text { e mais de 500 } \\
\text { em 1998 }\end{array}$ & $\sim 250$ & $\begin{array}{c}\sim 190 \\
\text { (cada cor é um } \\
\text { produto distinto) }\end{array}$ \\
\hline \hline $\begin{array}{l}\text { Quantidade de } \\
\text { novos produtos } \\
\text { lançados nos dois } \\
\text { últimos anos }\end{array}$ & 10 & 0 & Não sabem & $\sim 60$ & Não sabem \\
\hline \hline $\begin{array}{l}\text { Quanto } \\
\text { representam os } \\
\text { novos produtos no } \\
\text { faturamento atual }\end{array}$ & $\sim 25 \%$ & 0 & Não sabem & $\sim 30 \%$ & $\sim 25 \%$ \\
\hline
\end{tabular}

Apesar das limitações dos indicadores e de nem todas as empresas disporem desta informação, é possível se considerar as empresas A, D e E como inovadoras, no sentido de que uma parcela significativa da receita atual é gerada pelos novos produtos. A empresa $\mathbf{B}$, nitidamente não pode ser considerada inovadora pelo mesmo critério. Não foi possível classificar a empresa $\mathbf{C}$, devido a ausência de informações.

Para se tentar entender melhor o papel da inovação e indiretamente as possíveis razões que motivam ou desmotivam o comportamento inovador, foi indagado aos dirigentes das empresas quais os benefícios e dificuldades de se inovar. Os resultados comparativos são apresentados no quadro 5.6. 


\begin{tabular}{|c|c|c|c|c|c|}
\hline & EMPRESA A & EMPRESA B & EMPRESA C & EMPRESA D & EMPRESA E \\
\hline $\begin{array}{l}\text { Maiores } \\
\text { dificuldades para } \\
\text { inovar }\end{array}$ & $\begin{array}{l}\text { - Recursos } \\
\text { humanos } \\
\text { capacitados }\end{array}$ & $\begin{array}{l}\text { - Recursos } \\
\text { financeiros } \\
\text { - Enfocar a } \\
\text { equipe na } \\
\text { necessidade }\end{array}$ & $\begin{array}{l}\text { - Acesso às } \\
\text { matérias-primas } \\
\text { importadas }\end{array}$ & $\begin{array}{l}\text { - Aceitação dos } \\
\text { grandes clientes } \\
\text { - Indisponibilidad } \\
\text { e de tecnologia }\end{array}$ & $\begin{array}{l}\text { Desenvolver a } \\
\text { formulação } \\
\text { adequada }\end{array}$ \\
\hline $\begin{array}{l}\text { Os benefícios da } \\
\text { inovação para } \\
\text { a empresa }\end{array}$ & $\begin{array}{l}\text { - Crescimento } \\
\text { - Participação no } \\
\text { mercado } \\
\text { - Imagem no } \\
\text { mercado } \\
\text { - Confiança para } \\
\text { desenvolver } \\
\text { novos produtos }\end{array}$ & $\begin{array}{l}\text { Conseguir ver } \\
\text { um caminho } \\
\text { através dos } \\
\text { resultados }\end{array}$ & $\begin{array}{l}\text { - Manter a } \\
\text { carteira de } \\
\text { clientes mesmo } \\
\text { em situações de } \\
\text { crise }\end{array}$ & $\begin{array}{l}\text { - possibilidade de } \\
\text { competir com } \\
\text { as grandes } \\
\text { empresas } \\
\text { - Geração de } \\
\text { receita } \\
\text { - aumentar o } \\
\text { valor agregado } \\
\text { do produto }\end{array}$ & $\begin{array}{l}\text { - Possibilidade de } \\
\text { aumentar a } \\
\text { receita e reduzir } \\
\text { custos }\end{array}$ \\
\hline
\end{tabular}

As dificuldades declaradas fornecem uma pista das preocupações da empresa em relação ao processo de inovação e, provavelmente, também em relação ao seu negócio como um todo. É muito provável que estas dificuldades se relacionem com a experiência recente das empresas. Da mesma forma, os benefícios declarados demonstram, provavelmente, um desejo de atender a alguma necessidade das empresas. Esta proposição baseia-se, por analogia, nos experimentos realizados para se estudar as heurísticas ${ }^{3}$. Nesse sentido, com base nas declarações dos dirigentes e na observação do pesquisador durante as entrevistas e visita às empresas, é possível as seguintes inferências:

\section{- Empresa A}

Voltada prioritariamente para o desenvolvimento de seus recursos humanos como estratégia do negócio. Seu objetivo maior é crescer, mas mantendo uma imagem de excelência.

\section{- Empresa B}

Enfrenta dificuldades financeiras e prioriza os resultados operacionais.

\section{- Empresa C}

Em linha com sua visão de inovar através de acordos com empresas especialistas do exterior, sente dificuldades para poder importar algumas matéria-primas utilizadas por estes especialistas. Está com dificuldades para manter o faturamento e valoriza a fidelidade de alguns clientes.

\section{- Empresa D}


Está empenhada em se tornar fornecedora dos grandes consumidores potenciais e os novos produtos representam uma forte arma para alcançar este objetivo. Ao contrário da empresa $\mathbf{C}$, não acredita em acordos com terceiros para fornecimento de tecnologia e valoriza seus conhecimentos.

Sente as dificuldades da concorrência com as grandes empresas na sua tentativa de crescimento.

\section{- Empresa E}

$\mathrm{Na}$ verdade, não valoriza a inovação como meio de desenvolver a empresa e sim como conseqüência do seu objetivo de aumentar a linha de produtos e aumentar a receita. Apenas aceita a necessidade de acompanhar seus concorrentes e sente a dificuldade de descobrir as formulações destes.

As cinco empresas analisadas, conforme previsto na teoria, não possuem um processo de administração da inovação estruturado formalmente (Kruglianskas, 1996, Tidd \& Bessant \& Pavitt, 1997). Apenas uma das empresas, a D, possui um sistema estabelecido formalmente para análise e aprovação das idéias sobre desenvolvimento de produtos.

As empresas $\mathbf{A}$ e $\mathbf{C}$ atuam de forma parecidas quanto à fase inicial da administração da inovação, mas com objetivos e critérios distintos. A empresa B, que se dedica prioritariamente à inovação do processo produtivo, possui um processo distinto das outras empresas. A empresa E, voltada para a imitação dos produtos das empresas líderes do setor, também possui um processo de administração da inovação distinto das demais.

Neste trabalho, procurou-se conhecer o processo de inovação que cada empresa pratica, ainda que seja informal e de forma não estruturada. Considerando-se que o objetivo da pesquisa é o conhecimento de como e por que se decide inovar, procurou-se enfocar as fases iniciais do processo de inovação $^{4}$, basicamente, a geração de idéias, a seleção dessas idéias e a tomada da decisão em desenvolver determinado produto ou processo. Nesse sentido, não houve preocupação com as fases posteriores à decisão de inovar, isto é, as fases de desenvolvimento do projeto e de implantação.

Para se analisar o processo da administração, foi feita uma categorização do tipo de inovação praticado pela empresa, levando-se em conta a classificação da inovação proposta por Kamm (1987) e o grau de incerteza, conforme proposto por Freeman (1974), citado por

\footnotetext{
${ }^{3}$ As heurísticas "disponibilidade" e "caráter representativo", conforme apresentadas no item 2.5.2.3 desta dissertação, apresentam um mecanismo cognitivo aplicável na situação proposta.

${ }^{4}$ As fases iniciais do processo de administração da inovação, de acordo com o modelo proposto por Tidd \& Bessant \& Pavitt, 1997, p.41, refere-se às fases "processamento do sinal" e "estratégia".
} 
Kay (1979). O quadro 5.7 apresenta a análise do processo de inovação incluindo esta categorização.

\section{Quadro 5.70 processo de inovação das empresas}

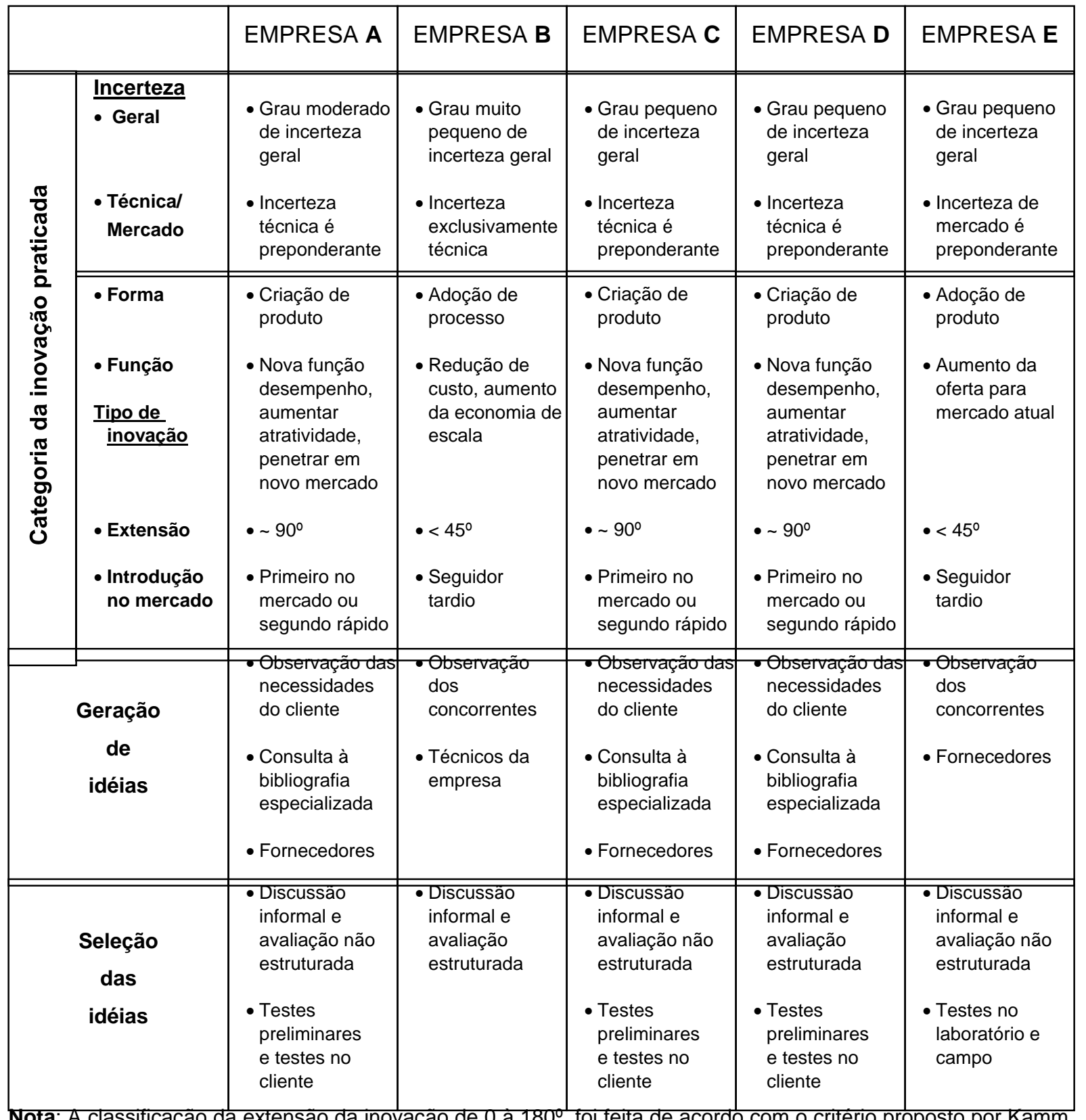

Nota: A classificaçáo da extensăo da inovaçao de 0 a $180^{\circ}$, fol feita de acordo com o criterío proposto por kamm, 1987, exposto no item 2.4 deste trabalho.

Através da análise do quadro 5.7, verifica-se que o grau de incerteza das inovações é pequeno e concentrado na incerteza técnica para quatro empresas. A empresa E, provavelmente por atender diretamente ao consumidor final, é a única que apresenta uma 
incerteza de mercado preponderante. As empresas A, C e D desenvolvem novos produtos através da criação de formulações, ainda que no caso da empresa $\mathbf{C}$ sejam freqüentes os acordos de transferência de tecnologia. As empresas B e E, praticam a adoção de processos e produtos já existentes no mercado. No caso do desenvolvimento de novos processos, esse tipo de comportamento era o esperado. Segundo a literatura (Freeman \& Soete, 1997) tal inovação é exclusiva das grandes empresas. A empresa E utiliza-se da adoção de produtos para atualizar e ampliar sua linha, de forma sistemática e objetiva.

Quanto à geração de idéias, quatro das cinco empresas utilizam os fornecedores como fonte, o que confirma as observações teóricas (Tidd \& Bessant \& Pavitt, 1997) e apenas a empresa B não utiliza esse recurso. A observação das necessidade dos clientes surgiu como fonte de idéias em três empresas, enquanto as outras duas preferem a observação dos concorrentes. Este fato pode ser entendido como uma caracterização das estratégias adotadas pelas empresas para competir no mercado; uma tipicamente reativa (acompanhar a concorrência) e a outra mais proativa (acompanhar as necessidades dos clientes).

Todas as empresas selecionam as melhores idéias de inovação por meio da discussão informal, principalmente entre as equipes de marketing e técnica. A escolha das alternativas de inovação, em geral, é feita de forma não estruturada. Apenas a empresa D possui um sistema previamente definido para essa avaliação.

Para analisar a razão que levou a empresa a desenvolver novos produtos ou processos, foram consideradas as duas questões propostas durante a entrevista. A primeira questão foi direta, "Por que sua empresa decidiu desenvolver novos produtos?". Para se tentar chegar à causa raiz, foram feitas mais duas perguntas sobre o porquê da resposta. $\mathrm{Na}$ segunda questão, o pesquisador apresentava uma lista de possíveis razões para a empresa ter se decidido a inovar e solicitava ao entrevistado que indicasse as que estavam relacionadas com a sua decisão. O resultado desta questões é apresentado no quadro 5.8. 
Quadro 5.8 Por que as empresas inovam

\begin{tabular}{|c|c|c|c|c|c|}
\hline & EMPRESA A & EMPRESA B & EMPRESA C & EMPRESA D & EMPRESA E \\
\hline $\begin{array}{l}\text { Por que decidiu } \\
\text { inovar? } \\
\text { (1) }\end{array}$ & $\begin{array}{l}\text { - Oportunidade, } \\
\text { filosofia da } \\
\text { empresa } \\
\text { - Crescer, } \\
\text { melhorar } \\
\text { - Fundamental, } \\
\text { mercado } \\
\text { dinâmico }\end{array}$ & $\begin{array}{l}\text { - Crescer e } \\
\text { sobreviver } \\
\text { - Criar escala de } \\
\text { produção } \\
\text { - Competir em } \\
\text { preço e } \\
\text { qualidade }\end{array}$ & $\begin{array}{l}\text { - Se diferenciar } \\
\text { - Atender os } \\
\text { clientes } \\
\text { - Permanecer no } \\
\text { mercado }\end{array}$ & $\begin{array}{l}\text { - Se diferenciar, } \\
\text { criar identidade } \\
\text { - Realização } \\
\text { profissional } \\
\text { - Sobreviver }\end{array}$ & $\begin{array}{l}\text { - Acompanhar o } \\
\text { mercado } \\
\text { - Sobreviver }\end{array}$ \\
\hline $\begin{array}{l}\text { Motivo da } \\
\text { decisão de } \\
\text { inovar } \\
\text { (2) }\end{array}$ & $\begin{array}{l}\text { - Pedido do } \\
\text { mercado } \\
\text { - Observação do } \\
\text { mercado } \\
\text { - Estratégia }\end{array}$ & $\begin{array}{l}\text { - Adoção de nova } \\
\text { tecnologia para } \\
\text { redução de } \\
\text { custo } \\
\text { - Estratégia }\end{array}$ & $\begin{array}{l}\text { - Observação do } \\
\text { mercado } \\
\text { - Ameaça de } \\
\text { produtos } \\
\text { importados } \\
\text { - Mudança na } \\
\text { legislação } \\
\text { - Estratégia }\end{array}$ & $\begin{array}{l}\text { - Pedido do } \\
\text { mercado } \\
\text { - Observação do } \\
\text { mercado } \\
\text { - Mudança na } \\
\text { legislação } \\
\text { - Estratégia }\end{array}$ & $\begin{array}{l}\text { - Concorrentes } \\
\text { - Observação do } \\
\text { mercado }\end{array}$ \\
\hline
\end{tabular}

Analisando-se as respostas obtidas para a questão (1), observa-se que, direta ou indiretamente, todos os entrevistados consideram a sobrevivência da empresa como uma das respostas. A resposta da empresa A, "fundamental" e da empresa C, "permanecer no mercado", podem ser entendidas como equivalentes à sobrevivência. As empresas A e B declaram diretamente "crescer" como razão da inovação e a empresa E, o faz indiretamente ao anotar "acompanhar o mercado". As empresas C e D, claramente, não vêem a inovação como forma de crescer e sim de se diferenciarem.

Quanto à questão (2), quatro empresas assinalaram a estratégia como uma das razões para inovar e apenas a empresa E não assinalou esta alternativa. Aparentemente, pelo conjunto de informações obtidas sobre esta empresa, presume-se que a estratégia de inovar é adotada implicitamente, mas não é considerada como tal pela empresa. A observação do mercado foi assinalada por quatro empresas, embora no caso da empresa $\mathbf{E}$, esta opção é claramente secundária. 


\subsection{Análise da tomada de decisão}

Para analisar a tomada de decisão sobre inovações das empresas pesquisadas, foram considerados os seguintes aspectos:

1) A racionalidade;

2) O processo;

3) A qualidade da decisão

Baron (1994), propõe um conceito de racionalidade que considera como racional o método empregado por uma pessoa para alcançar determinado objetivo, desde que exista a crença de ser essa a melhor forma de atingi-lo. A primeira das duas análises da racionalidade da decisão de inovar baseia-se nessa premissa e faz a comparação entre o objetivo maior da empresa e a resposta dos dirigentes entrevistados à questão: "Qual a relação das inovações com o objetivo da empresa". Cabe ressaltar que este critério, de natureza subjetiva, não leva em conta os preceitos de racionalidade da teoria da utilidade esperada.

Estas respostas são apresentadas no quadro 5.9.

\section{Quadro 5.9 A racionalidade da decisão de inovar nas empresas}

\begin{tabular}{|c|c|c|c|c|c|}
\hline & EMPRESA A & EMPRESA B & EMPRESA C & EMPRESA D & EMPRESA E \\
\hline $\begin{array}{l}\text { Decisão } \\
\text { analisada }\end{array}$ & $\begin{array}{l}\text { Desenvolvimento } \\
\text { de um biocida } \\
\text { com ação } \\
\text { fungicida e } \\
\text { algicida, chamado } \\
\text { de multiuso }\end{array}$ & $\begin{array}{l}\text { Modificação do } \\
\text { processo de } \\
\text { produção } \\
\text { (unidade de } \\
\text { formol) para } \\
\text { produzir o CUF }\end{array}$ & $\begin{array}{l}\text { Desenvolvimento } \\
\text { de um produto } \\
\text { para limpeza e } \\
\text { fosfatização do } \\
\text { alumínio }\end{array}$ & $\begin{array}{l}\text { Desenvolvimento } \\
\text { de um produto } \\
\text { para tratamento } \\
\text { de efluentes }\end{array}$ & $\begin{array}{l}\text { Desenvolvimento } \\
\text { de um produto } \\
\text { para } \\
\text { revestimento } \\
\text { decorativo }\end{array}$ \\
\hline $\begin{array}{l}\text { Qual o } \\
\text { objetivo } \\
\text { maior da } \\
\text { empresa? }\end{array}$ & $\begin{array}{l}\text { 1. Crescer } \\
\text { 2. Conquistar novos } \\
\text { mercados } \\
\text { 3. Atender bem os } \\
\text { clientes } \\
\end{array}$ & $\begin{array}{l}\text { 1.Aumentar a } \\
\text { produtividade } \\
\text { 2. Ocupar um lugar } \\
\text { no mercado }\end{array}$ & $\begin{array}{l}\text { 1.Reduzir a linha } \\
\text { de produtos } \\
\text { 2.Solidificar a } \\
\text { posição } \\
\text { 3.Aumentar a } \\
\text { rentabilidade }\end{array}$ & $\begin{array}{l}\text { 1.Conquistar o } \\
\text { mercado } \\
\text { 2.Crescer }\end{array}$ & $\begin{array}{l}\text { 1.Ampliar a linha } \\
\text { de produtos } \\
\text { 2.Crescer }\end{array}$ \\
\hline $\begin{array}{l}\text { Qual a } \\
\text { relação das } \\
\text { inovações } \\
\text { com o } \\
\text { objetivo da } \\
\text { empresa? }\end{array}$ & $\begin{array}{l}\text { 1.Novos } \\
\text { mercados } \\
\text { exigem novos } \\
\text { produtos }\end{array}$ & $\begin{array}{l}\text { 1.Possibilita } \\
\text { aumentar a } \\
\text { capacidade e } \\
\text { reduzir custos }\end{array}$ & $\begin{array}{l}\text { 1.Novos produtos } \\
\text { é inerente ao } \\
\text { negócio }\end{array}$ & $\begin{array}{l}\text { 1.Como a vida dos } \\
\text { produtos é curta, } \\
\text { é necessário } \\
\text { novos produtos } \\
\text { para manter os } \\
\text { clientes atuais e } \\
\text { conquistar novos }\end{array}$ & $\begin{array}{l}\text { 1.Os novos } \\
\text { produtos são } \\
\text { necessários } \\
\text { para crescer }\end{array}$ \\
\hline
\end{tabular}

A relação entre a inovação e os objetivos maiores da empresa apresentados pelos dirigentes faz sentido no caso das empresas A, B, D e E. No caso da empresa C, não se 
verificou nenhuma relação e ficou a impressão que a inovação é um mal necessário, isto é, não contribui para se alcançar o objetivo maior. Neste caso, aparentemente, a decisão de inovar é irracional.

A segunda análise da racionalidade, para se verificar a consistência da análise anterior, levou em conta o alinhamento entre o objetivo maior da empresa e o objetivo de inovar. Isto foi avaliado pelas duas questões apresentadas anteriormente: "por que decidiu inovar" e "benefícios da inovação". Assim, considera-se que a decisão de inovar é racional se pelo menos um dos objetivos maiores for atendido pelos objetivos de inovar e se não houver objetivos contraditórios.

O quadro 5.10 apresenta uma segunda análise da racionalidade das cinco empresas.

\section{Quadro 5.10 Consistência da racionalidade}

\begin{tabular}{|c|c|c|c|c|c|}
\hline & EMPRESA A & EMPRESA B & EMPRESA C & EMPRESA D & EMPRESA E \\
\hline $\begin{array}{l}\text { Qual o } \\
\text { objetivo } \\
\text { maior da } \\
\text { empresa? }\end{array}$ & $\begin{array}{l}\text { 1. Crescer } \\
\text { 2. Conquistar novos } \\
\text { mercados } \\
\text { 3. Atender bem os } \\
\text { clientes } \\
\end{array}$ & $\begin{array}{l}\text { 1.Aumentar a } \\
\text { produtividade } \\
\text { 2. Ocupar um lugar } \\
\text { no mercado }\end{array}$ & $\begin{array}{l}\text { 1. Reduzir a linha } \\
\text { de produtos } \\
\text { 2.Solidificar a } \\
\text { posição } \\
\text { 3.Aumentar a } \\
\text { rentabilidade }\end{array}$ & $\begin{array}{l}\text { 1.Conquistar o } \\
\text { mercado } \\
\text { 2.Crescer }\end{array}$ & $\begin{array}{l}\text { 1.Ampliar a linha } \\
\text { de produtos } \\
\text { 2.Crescer }\end{array}$ \\
\hline $\begin{array}{l}\text { Os } \\
\text { benefícios } \\
\text { da } \\
\text { inovação } \\
\text { para a } \\
\text { empresa }\end{array}$ & $\begin{array}{l}\text { 1.Crescimento } \\
\text { 2.Participação no } \\
\text { mercado } \\
\text { 3.Imagem no } \\
\text { mercado } \\
\text { 4.Confiança para } \\
\text { desenvolver } \\
\text { novos produtos }\end{array}$ & $\begin{array}{l}\text { 6.Conseguir ver } \\
\text { um caminho } \\
\text { através dos } \\
\text { resultados }\end{array}$ & $\begin{array}{l}\text { 8.Manter a carteira } \\
\text { de clientes } \\
\text { mesmo em } \\
\text { situações de } \\
\text { crise }\end{array}$ & $\begin{array}{l}\text { 12.possibilidade } \\
\text { de competir } \\
\text { com as grandes } \\
\text { empresas } \\
\text { 13.Geração de } \\
\text { receita } \\
\text { 14.aumentar o } \\
\text { valor agregado } \\
\text { do produto } \\
\end{array}$ & $\begin{array}{l}\text { 10.Possibilidade } \\
\text { de aumentar } \\
\text { a receita e } \\
\text { reduzir custos }\end{array}$ \\
\hline $\begin{array}{l}\text { Por que } \\
\text { decidiu } \\
\text { inovar? }\end{array}$ & $\begin{array}{l}\text { 31.Oportunidade, } \\
\text { filosofia da } \\
\text { empresa } \\
\text { 32.Crescer, } \\
\text { melhorar } \\
\text { 5.Fundamental, } \\
\text { mercado } \\
\text { dinâmico }\end{array}$ & $\begin{array}{l}27 . \text { Crescer e } \\
\text { sobreviver } \\
28 . \text { Criar escala de } \\
\text { produção } \\
\text { 29. Competir em } \\
\text { preço e } \\
\text { qualidade }\end{array}$ & $\begin{array}{l}\text { 23.Se diferenciar } \\
\text { 24.Atender os } \\
\text { clientes } \\
\text { 25.Permanecer no } \\
\text { mercado }\end{array}$ & $\begin{array}{l}\text { 19.Se diferenciar, } \\
\text { criar identidade } \\
\text { 20.Realização } \\
\text { profissional } \\
\text { 21.Sobreviver }\end{array}$ & $\begin{array}{l}\text { 16.Acompanhar o } \\
\text { mercado } \\
\text { 17.Sobreviver }\end{array}$ \\
\hline
\end{tabular}

Comparando-se os objetivos maiores da empresa com os benefícios da inovação e os objetivos da inovação (razões declaradas para inovar), de cada empresa, chega-se aos seguintes resultados: 


\section{- Empresa A}

O objetivo maior (1), crescer, surgiu também como objetivos da inovação (1) e (6). O objetivo maior (2), conquistar novos mercados, aparece em objetivo da inovação (2). O objetivo maior (3), atender bem os clientes, aparentemente, não foi relacionado com os objetivos de inovar. Como os objetivos da inovação (3), (4), (5) e (7) não contradizem os objetivos maiores da empresa e dois objetivos maiores foram atendidos pela inovação, a decisão de inovar foi considerada racional.

\section{- Empresa B}

O objetivo maior (1), aumentar a produtividade, embora não declarado explicitamente como objetivo da inovação, está fortemente relacionado com os objetivos (3) e (4). O objetivo maior (2), ocupar um lugar no mercado está relacionado com o objetivo da inovação (2). Como não existe contradição entre os objetivos, a decisão de inovar foi considerada racional.

\section{- Empresa C}

Aparentemente não existe uma relação entre os objetivos maiores da empresa e os objetivos de se inovar. Ao contrário, existe alguma contradição entre o objetivo maior (1), reduzir a linha de produtos, e os objetivos da inovação (2) e (3). Neste caso considerou-se que a decisão de inovar não é racional.

\section{- Empresa D}

Os objetivos maiores da empresa (1) e (2), conquistar o mercado e crescer podem ser considerados como um único objetivo e perfeitamente relacionados com os objetivos da inovação (1), (2) e (6). Não existe contradição entre os objetivos e portanto a decisão de inovar foi considerada racional.

\section{- Empresa E}

O objetivo maior (1), ampliar a linha de produtos, está diretamente relacionado com os objetivos (1) e (2) da inovação e não existe contradição entre os objetivos. Neste caso foi considerado que a decisão de inovar é racional.

A análise do processo de tomada de decisão nas cinco empresas foi baseado em três aspectos: "quem participa da decisão", "como é tomada a decisão" e o "risco da decisão". Para realização desta análise foi considerada, por escolha da empresa, uma decisão importante e que estivesse gravada na memória dos entrevistados. As decisões 
escolhidas pelas empresas A, C, D e E referem-se a desenvolvimento de produtos que foram lançados no mercado com sucesso. No caso da empresa $\mathbf{B}$, a decisão escolhida foi de um desenvolvimento do processo de produção que ainda está em fase de implantação.

A informação de quem participa da decisão foi dada pelo principal dirigente da empresa e confirmada com pelo menos mais uma pessoa. Quanto ao processo de tomada da decisão e o risco envolvido foi baseado nas informações recebidas e na observação do pesquisador. Um resumo do processo de decisão das cinco empresas é apresentado no quadro 5.11.

\section{Quadro 5.11 Processo de decisão das empresas}

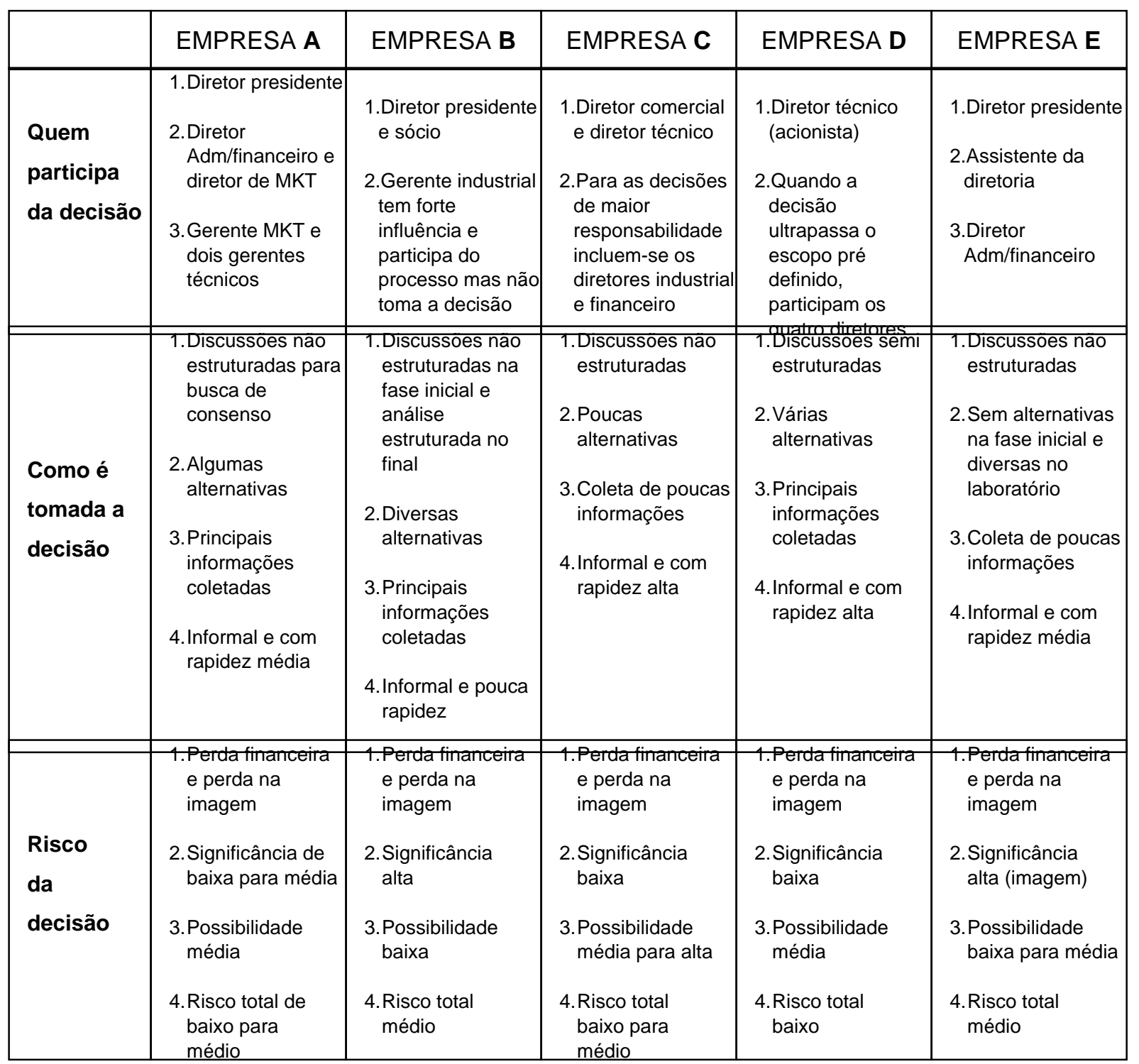

A empresa A é a que possui maior participação das diversas áreas na tomada de decisão, enquanto a empresa $\mathbf{D}$ é a que envolve o menor número de pessoas, apenas o diretor técnico nas decisões normais de inovação. Como conseqüência, o processo na 
primeira é significativamente mais lento do que na segunda, com possíveis ganhos na qualidade da decisão. Na empresa $\mathbf{E}$, três pessoas participam do processo, enquanto nas empresas B e C, apenas duas tomam a decisão. Em geral, as empresas discutem as alternativas de desenvolvimento informalmente, por telefone ou em reuniões, de forma não estruturada. Apenas a empresa D possui um formato pré-determinado para analisar as alternativas de desenvolvimento. As cinco empresas não fazem avaliação do risco das suas decisões. Em geral, quando perguntados sobre qual o risco de se desenvolver um novo produto ou processo, os dirigentes o consideraram insignificante.

A análise da qualidade da decisão em inovação foi feita de acordo com o modelo proposto por Matheson \& Matheson (1998). Este modelo considera seis quesitos para definir a qualidade: 1. estrutura, 2. alternativas, 3. informações, 4. valores e trade offs, 5. raciocínio lógico e 6 . compromisso para ação. Para cada quesito foi atribuído uma nota que varia de um a sete. A tabela 5.1 apresenta o resultado desta análise.

Tabela 5.1 Resultado da medição da qualidade de decisão

\begin{tabular}{|l|ccccc|}
\hline QUESITOS EMPRESAS & A & B & C & D & E \\
\hline 1. Estrutura & 6 & 6 & 4 & 6 & 3 \\
2. Alternativas & 6 & 7 & 4 & 6 & 3 \\
3. Informações & 5 & 5 & 5 & 5 & 4 \\
4. Valores e trade offs & 4 & 5 & 3 & 5 & 2 \\
5. Raciocínio lógico & 4 & 5 & 4 & 4 & 4 \\
6. Compromisso para ação & 7 & 6 & 5 & 6 & 5 \\
\hline POSıçÃo & $2^{\circ}$ & $1^{\circ}$ & $4^{\circ}$ & $2^{\circ}$ & $5^{\circ}$ \\
\hline
\end{tabular}

De acordo com este método de medição, a qualidade da decisão da empresa B é a que atingiu o melhor nível. Ela é igual ou superior as outras empresas em todos os quesitos exceto em compromisso para ação, em que a empresa $\mathbf{A}$ é um pouco melhor. As empresas A e D estão, praticamente, no mesmo nível de qualidade e pouca coisa inferior à empresa $\mathbf{B}$. Em quarto lugar, vem a empresa $\mathbf{C}$ e por último a empresa $\mathbf{E}$.

Dadas as características do método de medição, absolutamente subjetivas, não é possível uma comparação quantitativa absoluta entre as empresas, isto é, não é possível se avaliar o quanto uma empresa é melhor que a outra. Mas considerando-se que a avaliação 
das cinco empresas foi feita pelo mesmo avaliador e com um critério pré- estabelecido, é possível o ordenamento das empresas nos diversos quesitos.

Cabe ressaltar que esta avaliação foi feita considerando apenas uma determinada decisão, escolhida pela empresa. No caso das empresas A, C, D e E em que a decisão objeto do estudo trata de um desenvolvimento de produto, repetido algumas vezes durante um ano, com características semelhantes, a comparação tem mais validade. No caso da empresa B, a decisão escolhida para análise foi relativa ao desenvolvimento do processo de produção e de alto valor monetário para a empresa. Certamente, não é uma decisão freqüente e por esta razão a comparação com as decisões das outras empresas fica prejudicada.

\subsection{Análise da percepção e tolerância ao risco}

\section{A percepcão}

A avaliação da percepção do risco foi feita através da aplicação de um teste com os principais dirigentes de cada empresa. O teste conforme descrito no "Roteiro para aplicação do teste de percepção" (modelo anexado ao capítulo sete), apresenta uma situação de desenvolvimento de um novo produto e solicita ao entrevistado que avalie a possibilidade de fracasso do desenvolvimento. Esta avaliação representa a probabilidade de fracasso, portanto um valor numérico. Ao mesmo tempo, essa avaliação expressa uma possibilidade de perda ou risco existente.

O teste aplicado com as cinco empresas pode ser considerado padronizado, no sentido de propor a mesma situação problema. Por outro lado, foi ressaltado que aquele cenário deveria ser tratado como uma situação real da empresa. Nessas condições, o resultado do teste reflete a percepção do risco de cada dirigente sobre uma decisão de inovação "padrão" tomada na sua empresa.

Os resultados obtidos no teste são apresentados na tabela 5.2. O decisor "a" é o dirigente principal da empresa. 
Tabela 5.2 Resultado do teste de percepção do risco (probabilidade de fracasso)

\begin{tabular}{|c|c|c|c|c|c|}
\hline DECISORES EMPRESAS & A & B & C & D & E \\
\hline a & 40 & 40 & 80 & 80 & 50 \\
\hline b & 30 & 75 & 58 & 50 & 20 \\
\hline c & 33 & & 50 & & 40 \\
\hline d & 60 & & & & \\
\hline Média & 40,8 & 57,5 & 62,7 & 65,0 & 36,7 \\
\hline Amplitude & 30,0 & 35,0 & 30,0 & 30,0 & 30,0 \\
\hline Variância & 546,8 & 612,5 & 482,7 & 450,0 & 466,7 \\
\hline
\end{tabular}

Em princípio, a percepção dos decisores de uma determinada empresa está sujeita às mesmas condições de risco e experiências daquela empresa. O único fator que varia entre os decisores da mesma empresa, possibilitando percepções diferentes, é o aspecto pessoal da percepção. Conforme abordado na teoria, existem diversos fatores que influenciam a percepção dos indivíduos, entre outros, experiência, expectativa e desejos (Davidoff, 1983).

Neste sentido, na empresa $\mathbf{A}$, os decisores $\mathbf{a}, \mathbf{b}$, e c possuem uma percepção bem próximas, enquanto o decisor d está bem distante dos demais. Se fossem considerados apenas os três decisores a, b e c, o valor médio da percepção seria 34,3, a amplitude seria 10 e a variância cairia para 52,7.

As empresas B e $\mathbf{D}$, onde foi medida a percepção de apenas dois decisores, apresentam uma grande discrepância na percepção dos decisores. Nas empresas C e E, com a medida de três decisores, também verificou-se uma grande discrepância de percepção entre os decisores.

Comparando-se as percepções médias das empresas é possível observar que:

- A empresa $\mathbf{E}$ apresenta o menor valor enquanto a empresa $\mathbf{D}$ apresenta o maior;

- As empresas B e C apresentam valores médios da percepção próximos;

- As empresas A apresenta valor médio da percepção próximo do mínimo. 
Não foi encontrado na teoria, informações sobre a relação entre a percepção dos decisores com outros efeitos para a decisão. Neste sentido, é possível apenas algumas especulações, do tipo:

Existe maior possibilidade de decisões consensuais quando os decisores possuem percepções próximas.

A diversidade de percepção entre os decisores possibilita o enriquecimento do processo de decisão; provavelmente, são geradas mais alternativas de ação.

O aprofundamento do estudo da percepção na tomada de decisão exigiria outras pesquisas, que devido as limitações, não fazem parte do escopo deste trabalho. Desta forma, a pesquisa realizada serviu para confirmar que a percepção entre os decisores pode variar significativamente, principalmente em função de fatores pessoais.

Também é possível inferir que a percepção, como fator que influencia a decisão, precede a tolerância, no sentido de que uma pessoa pode tolerar mais ou menos apenas aquilo que é percebido. Acredita-se, que se a percepção do risco for extrema, isto é, absolutamente nenhuma ou máxima, a tolerância, qualquer que seja, não terá influência na decisão.

Aparentemente, a consideração da percepção como tal, pode contribuir para reduzir os vieses na análise da decisão.

\section{A Tolerância}

A avaliação da tolerância ao risco de cada empresa foi feita através da aplicação de um teste com os seus principais dirigentes. O teste, conforme descrito no "Roteiro para aplicação do teste de tolerância" (modelo anexado ao capítulo sete), apresenta uma situação de desenvolvimento de um novo produto e solicita ao entrevistado que apresente a sua decisão.

Os resultados obtidos no teste são apresentados na tabela 5.3. 
Tabela 5.3 Resultado do teste de tolerância ao risco (parâmetro R)

\begin{tabular}{|c|c|c|c|c|c|c|c|c|c|c|}
\hline \multirow{2}{*}{ Decisores } & \multicolumn{2}{|c|}{ A } & \multicolumn{2}{|c|}{ B } & \multicolumn{2}{|c|}{ C } & \multicolumn{2}{|c|}{ D } & \multicolumn{2}{|c|}{ E } \\
\hline & $(\mathrm{R} \$)$ & $\%$ vendas & $(\mathrm{R} \$)$ & $\%$ & $(\mathrm{R} \$)$ & $\%$ & $(\mathrm{R} \$)$ & $\%$ vendas & $(\mathrm{R} \$)$ & $\%$ vendas \\
\hline a & 425.000 & 7,2 & 240.000 & 2,1 & 80.000 & 1,1 & 300.000 & 6,3 & 700.000 & 4,7 \\
\hline b & 235.000 & 4,0 & 700.000 & 6,1 & 420.000 & 6,0 & 300.000 & 6,3 & ND & ND \\
\hline c & ND & ND & & & 300.000 & 4,3 & & & ND & ND \\
\hline d & 240.000 & 4,1 & & & & & & & & \\
\hline Média & 300.000 & 5,1 & 470.000 & 4,1 & 266.700 & 3,8 & 300.000 & 6,3 & 700.000 & 4,7 \\
\hline
\end{tabular}

Os decisores assinalados com ND preferiram não declarar um valor, considerando a situação proposta pelo teste (50\% de chance de sucesso e $50 \%$ de fracasso) como de alto risco. Nesta situação haveria possibilidade de se aplicar outro tipo de teste para determinar a tolerância ao risco destas pessoas; não obstante, optou-se por excluir esses resultados, mantendo-se um único teste para todos.

Considerando-se, que quanto maior a tolerância ao risco (parâmetro R) menos contrária ao risco será a pessoa e analisando-se os resultados do teste, é possível observar que a empresa $\mathbf{E}$, na média de seus decisores, é a que tem menos aversão ao risco em valores monetários absolutos.

Aparentemente, faz mais sentido uma análise que considere o valor da tolerância em função da porcentagem do faturamento, pois, embora as cinco empresas sejam de pequeno porte, o faturamento delas apresenta uma grande variação. Também é de se esperar que as inovações das empresas com maior faturamento apresentem valores maiores e conseqüentemente, seus decisores estejam familiarizados com valores mais altos.

Howard (1988) considera o valor de 6,4 \% das vendas, ou faturamento, como sendo um valor razoável. Aparentemente este valor surgiu como resultado de diversas pesquisas realizadas pelo autor com grandes empresas americanas.

Nas cinco empresas estudadas, apenas a empresa D com tolerância de 6,3\% do faturamento apresenta um valor compatível com a estimativa de Howard. As empresas A com 5,1\%, E com 4,7\%, B com 4,1 e C com 3,8\% estão mais próximas de um valor médio em torno de $4,8 \%$.

A tabela 5.4 alinha a apresentação dos resultados dos dois testes. 
Tabela 5.4 Resultado dos testes de percepção e tolerância

\begin{tabular}{|c|c|c|c|c|c|c|c|c|c|c|}
\hline \multirow{2}{*}{$\begin{array}{l}\text { Decisores } \\
\mathbf{a}\end{array}$} & \multicolumn{2}{|c|}{$\begin{array}{r}\text { A } \\
\text { Percepção }\end{array}$} & \multicolumn{2}{|c|}{ Percepção } & \multicolumn{2}{|c|}{$\begin{array}{c}\text { C } \\
\text { Percepção }\end{array}$} & \multicolumn{2}{|c|}{$\begin{array}{r}\text { D } \\
\text { Percepção }\end{array}$} & \multicolumn{2}{|c|}{ Percepção } \\
\hline & 40 & 7,2 & 40 & 2,1 & 80 & 1,1 & 80 & 6,3 & 50 & 4,7 \\
\hline b & 30 & 4,0 & 75 & 6,1 & 58 & 6,0 & 50 & 6,3 & 20 & ND \\
\hline C & 33 & ND & & & 50 & 4,3 & & & 40 & ND \\
\hline d & 60 & 4,1 & & & & & & & & \\
\hline Média & 40,8 & 5,1 & 57,5 & 4,1 & 62,7 & 3,8 & 65 & 6,3 & 36,7 & 4,7 \\
\hline
\end{tabular}

Calculando-se o coeficiente de correlação linear verifica-se que não existe uma relação linear entre a percepção e a tolerância ao risco $(r=-0,027)$. Analisando-se o gráfico de dispersão também não foi possível identificar algum tipo de relação entre a percepção e a tolerância ao risco.

Conforme se esperava, aparentemente, não existe uma relação entre a percepção e a tolerância ao risco. Esta observação reforça a idéia de que a medição da percepção pode contribuir para a análise da decisão. 


\section{CAPÍTULO 6}

\section{CONCLUSÕES}

A diversidade e complexidade do processo de administração da inovação permite que sua análise seja feita sob diversos ângulos. Assim, qualquer estudo sobre a tomada de decisão em inovação corre o risco de não apresentar uma visão ampla do assunto ou de ficar na superficialidade. Espera-se que neste trabalho tenha havido uma abordagem do assunto com equilíbrio suficiente para permitir algumas conclusões contributivas à administração das pequenas indústrias químicas na amplitude e profundidade adequadas.

O estudo empírico realizado com as cinco pequenas indústrias químicas permitiu o entendimento do processo de administração da inovação e a formulação de hipóteses sobre as formas como essas empresas tomam a decisão de desenvolver novos produtos e processos, bem como as razões que as levam a essa decisão. Desse modo, as conclusões apresentadas neste trabalho refletem as evidências observadas na análise comparativa dos casos pesquisados, estando portanto restritas ao universo das pequenas indústrias químicas e sujeitas às imprecisões inerentes a um estudo exploratório. Absolutamente, não podem ser consideradas afirmações prescritivas para a tomada de decisão; ao contrário, espera-se que tenham utilidade como observações de caráter descritivo do processo de decisão.

\subsection{Conclusões do estudo sobre por que se decide inovar}

Aparentemente, não existe uma justificativa única ou algum fator determinante na tomada de decisão em desenvolver novos produtos ou processos. Todavia, através da análise de cada caso, identifica-se algumas possíveis explicações desta decisão.

A análise do processo de decisão demonstrou que existem três grandes componentes que participam direta ou indiretamente da tomada de decisão em inovação na pequena indústria química, que são: 1) o ambiente externo ou aspectos econômicos representados pelos fatores exógenos; 2) a organização através dos fatores endógenos; 3) a vontade pessoal dos decisores. 


\subsubsection{Os fatores exógenos}

Como fatores exógenos entende-se os principais aspectos econômicos que influenciam a tomada de decisão em inovação. Os dois fatores exógenos identificados neste trabalho foram: a competição e o tipo de inovação. Esses fatores são, na verdade, uma síntese de muitos outros, não existe a pretensão de que representem uma lista exaustiva dos fatores, ao contrário, são apenas os que foram possíveis de se detectar dentro das limitações deste estudo. Além dos aspectos econômicos, existem outros tipos de influência, como por exemplo, os aspectos sociais e culturais, que não foram objeto deste estudo pois considerou-se que este tipo de influência age de forma mais intensa nos indivíduos _ que por sua vez vão influenciar a decisão _ do que diretamente nas organizações.

\section{A competicão}

Exprime as características e condições de negociação entre os agentes de um determinado mercado. O termo competição empregado neste trabalho está de acordo com o conceito de concorrência utilizado por Porter (1986), onde as cinco forças que atuam em um setor definem sua estrutura e o nível de concorrência existente. No caso do setor de especialidades químicas, foi possível observar que independente da vontade da empresa havia a necessidade de desenvolver um novo produto para manter um cliente ou tentar conquistar um novo. Esta dependência da inovação, aparentemente, surge da intensidade da competição. Ao contrário, setores onde a competição é mais branda, como o caso de biocidas, a pressão por novos produtos também é menor.

\section{O tipo de inovacão}

Aparentemente, a simplicidade, o custo reduzido e a rapidez no processo de desenvolvimento de novos produtos são os principais indutores da inovação. O exemplo típico de um setor bastante inovador é o de especialidades químicas. Nesse setor, novos produtos são desenvolvidos, testados e produzidos em algumas semanas, com a mobilização de poucos recursos materiais. O processo de desenvolvimento é relativamente simples, consta basicamente de se descobrir uma formulação adequada a uma determinada aplicação no mercado. As possibilidades de combinação dos diversos elementos, em diferentes quantidades, resulta praticamente em infinitos produtos. Outro aspecto que provoca o surgimento constante de novos produtos, é a facilidade de se descobrir a formulação e imitar o produto inédito. Neste sentido, os fabricantes de especialidades químicas estão constantemente lançando novos produtos no mercado, seja para se aproveitar da alta margem de lucro, temporária, de um produto inédito, seja acompanhando 
os concorrentes para não perder um cliente. Esta disputa do mercado reduz a vida dos produtos e obriga as empresas a serem inovadoras.

Considerando-se o conceito de tecnologia proposto por Kruglianskas (1996), onde este termo representa um conjunto de conhecimentos necessários para se conceber, produzir e distribuir bens e serviços de forma competitiva, é possível inferir que o tipo de inovação está relacionado ao tipo de tecnologia empregada.

O tipo de inovação poderia ter sido considerado como um dos fatores que influenciam a competição. Esta concepção provavelmente não seria incoerente, pois certamente existe alguma relação entre eles. A razão pela qual este estudo assume o tipo de inovação como um fator à parte é a evidência de que representa, isoladamente, um importante fator para determinar a intensidade de inovação no setor industrial e não significa que esteja sendo negada a sua relação com a competição.

O tipo de inovação, aparentemente, tem forte influência sobre a intensidade de novos produtos que surgem no mercado.

A atribuição do tipo de inovação ao ambiente externo pode provocar algumas controvérsias. Dentro de certos limites, admite-se que exista uma influência da empresa no tipo de inovação praticada, porém acredita-se que as características determinantes do processo sejam impostas pelo mercado. Essa observação coincide com a visão de Schumpeter que considerava a produção como uma combinação de materiais e forças disponíveis com o objetivo determinado pelo sistema econômico. Em outras palavras, a tecnologia só desenvolve métodos de produção para utilidades requeridas: a lógica econômica prevalece sobre a técnica.

\subsubsection{Os fatores endógenos}

Os fatores endógenos representam as principais forças internas da organização, que atuam no sentido de facilitar ou dificultar a decisão pela inovação. A mesma consideração feita quanto aos fatores exógenos, também cabe neste caso, isto é, estes fatores representam uma tentativa de síntese dos diversos aspectos existentes na complexa realidade de uma empresa. Os principais fatores endógenos identificados foram: a defasagem tecnológica e o valor da qualidade. 


\section{A defasagem tecnológica}

É a diferença entre a tecnologia praticada pelos principais participantes do mercado e a existente na empresa em questão. Esta diferença pode ocorrer tanto em relação ao produto como com o processo. O caso da empresa B que tem uma defasagem tecnológica no processo de produção demonstra que o principal efeito desta situação é a falta de competitividade em custo. Este fato obriga a empresa a se decidir pela inovação na tentativa de reduzir a defasagem e se tornar competitiva.

Quando a defasagem tecnológica está relacionada com o produto, aparentemente, o efeito pode ser mais drástico, provocando grandes quedas nas vendas. Esta queda pode ser mais ou menos rápida, dependendo do grau de competição existente no mercado e da reação da própria empresa. O caso da empresa $\mathbf{C}$, aparentemente, além de outros problemas relacionados à estratégia, indica a existência de uma situação de defasagem tecnológica do produto, que tem provocado uma queda no faturamento durante os últimos anos.

Por outro lado, é possível inferir o efeito contrário deste fator. Quando uma empresa se encontra em situação de vantagem tecnológica em relação aos seus concorrentes, o fator pode agir como um desestimulador da inovação.

\section{O valor da qualidade}

Nos cinco casos estudados, as empresas consideradas como mais inovadoras foram aquelas que mais valorizavam a qualidade. A valorização da qualidade em uma organização, conforme observado por Garvin, citado por Queiroz (1995), pode ser verificada através do compromisso da alta gerência com ela. Na pequena empresa, aparentemente, é mais fácil de ser verificado se existe ou não este compromisso da direção. Outra forma prática e bastante razoável de se verificar a importância que a qualidade tem para a empresa é através da quantidade de treinamento que é oferecida aos seus funcionários. A qualidade neste caso está de acordo com o conceito que tem no "Controle da Qualidade Total" (TQC), conforme Campos (1992).

Esta relação entre a importância da qualidade para a empresa e o quanto a mesma é inovadora encontra uma sustentação no fato de existir a preocupação com o desenvolvimento de novos produtos e processos na "Qualidade Total", normalmente chamado de melhoria contínua. A melhoria contínua nada mais é do que a inovação incremental. Além deste fato, a "Qualidade Total", conforme Ishikawa (1993), propõe que a verdadeira garantia da qualidade se inicia com a qualidade do desenvolvimento de novos produtos. A figura 6.1 traduz a idéia de que existe uma relação direta entre a importância da qualidade e o grau de inovação para a pequena empresa. 


\section{Figura 6.1 Matriz da relação entre qualidade e inovação}

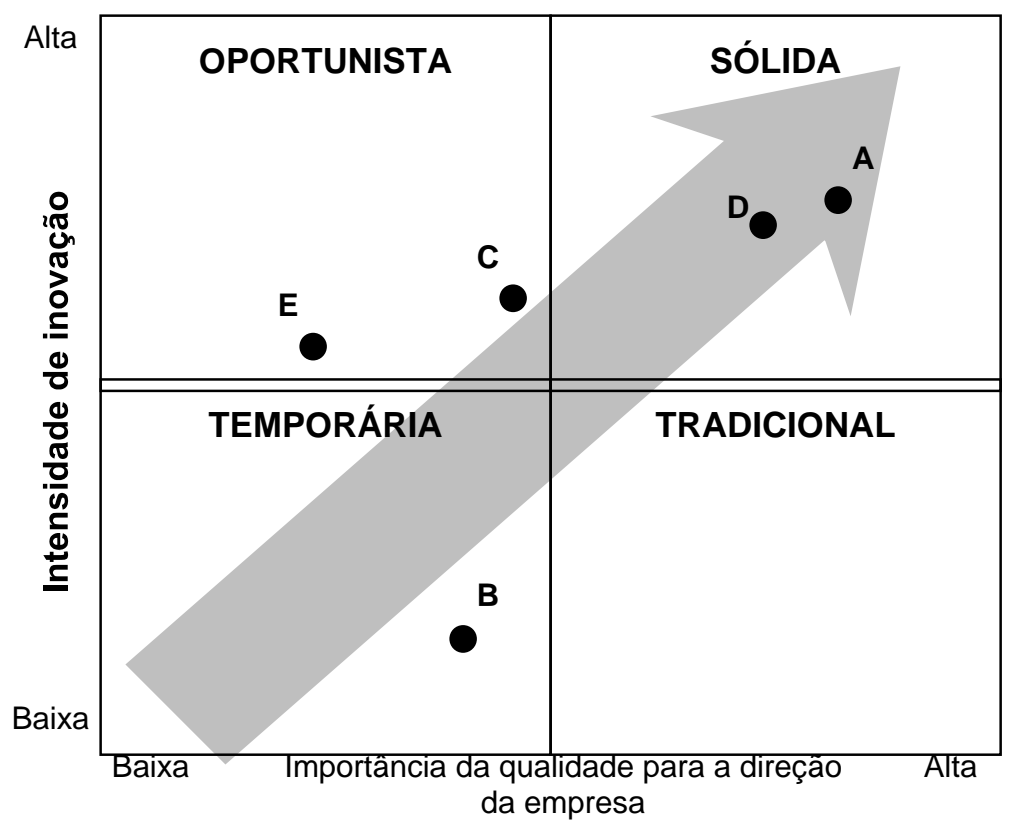

A intensidade de inovação pode ser medida de diversas formas, tais como: número de produtos lançados no mercado por ano, participação nas vendas dos produtos desenvolvidos nos dois últimos anos e outros.

A importância da qualidade para a direção da empresa pode ser verificada diretamente, no caso das pequenas empresas, por meio de entrevistas com os dirigentes, ou indiretamente, através de alguns indicadores, como por exemplo: horas gastas com treinamento, número de reclamações e outras formas.

A matriz da figura 6.1 é uma forma de representar as possibilidades de combinação entre a intensidade de inovação que a empresa pratica e a importância que atribui à qualidade. Acredita-se que o caminho ideal para a pequena empresa seja o indicado pela seta, que oferece a melhor oportunidade de crescimento sustentável no longo prazo. As empresas A, B, C, D e E, pesquisadas neste trabalho foram posicionadas de acordo com a avaliação do pesquisador, tendo por base as informações obtidas durante as entrevistas.

O nome dado a cada quadrante serve apenas como ilustração. Assim, o quadrante inferior à esquerda foi chamado de "Temporária", pois imagina-se que qualquer pequena empresa não consiga sobreviver por longo período nesta situação. O quadrante "Tradicional" é uma alusão às pequenas empresas que possuem um alto nível de qualidade, mas não costumam praticar a inovação, como por exemplo alguns pequenos restaurantes tradicionais. No caso de uma pequena indústria química, esta condição, aparentemente, é inviável, pelo menos por períodos longos. O quadrante "Oportunista" 
demonstra uma situação que não se sustenta a longo prazo, mas é passível de sobreviver durante períodos relativamente curtos. Finalmente, o quadrante "Sólida" que representa a situação ideal para o crescimento da pequena empresa.

\subsubsection{A vontade pessoal dos decisores}

Com base nos dados obtidos nesta pesquisa foi possível comprovar que a percepção do risco, conforme previsto por Plous (1993) e Skinner (1999), é inerentemente subjetiva. Os decisores da mesma empresa percebem de forma diferente o risco existente em uma determinada situação, confirmando, assim, a existência de um fator pessoal na percepção do risco. Nesta pesquisa, as duas empresas que possuem maiores semelhanças no tipo de negócio, as empresas C e D, foram as que apresentaram valores da percepção medida mais próximos, sugerindo que pode haver uma influência do ambiente empresarial na percepção das pessoas.

Quanto à tolerância ao risco em inovação, verificou-se que existe uma grande discrepância entre os decisores de uma mesma empresa, tanto em valores absolutos como em porcentagem das vendas, confirmando o caráter pessoal da tolerância ao risco. Também não foi possível observar qualquer semelhança provocada pelo ambiente empresarial. Aparentemente, a percepção do risco está mais sujeita às influências do ambiente empresarial do que a tolerância.

A vontade pessoal do decisores pode ser representada, de forma simplificada, através dos estudos sobre a tolerância ao risco. Os dois principais modelos nesta área são: a) o modelo da teoria da utilidade esperada de von Neumann \& Morgenstern (1947) que define um conjunto de premissas ou axiomas que caracterizariam o comportamento racional na tomada de decisão; b) o modelo da teoria da perspectiva, desenvolvida por Daniel Kahneman e Amos Tversky em 1979, mais próximo da situação real de decisão.

Nesses dois modelos existe a premissa de que o risco é assumido pelo indivíduo deliberadamente, isto é, o indivíduo decide como agir levando em conta o risco e outros fatores existentes (Yates, 1994, p. 321). Essa premissa, aparentemente, não corresponde à realidade.

As cinco empresas pesquisadas não fazem uma análise formal ou estruturada do risco durante o processo de decisão em inovação, sugerindo que o risco é considerado neste processo apenas intuitivamente ou não deliberado. 
Com a inclusão de uma avaliação sobre a percepção do risco precedendo a avaliação da tolerância ao risco, o pesquisador acredita ser possível adaptar os modelos existentes a uma condição mais realista, que levaria em conta se o risco assumido é deliberado ou não. Esta conclusão está baseada nos seguintes pontos:

- O teste de percepção do risco aplicado aos decisores, permitiu comprovar a teoria no sentido de que existe uma grande variação na percepção das pessoas para um mesmo fato (Plous, 1993 e Davidoff, 1983).

- Aparentemente não existe relação entre a percepção e a tolerância. No teste realizado com os decisores das empresas pesquisadas o coeficiente de correlação foi de $-0,027$.

- A percepção, segundo Skinner (1999) é fruto das contingências as quais a pessoa foi exposta durante a vida. Neste sentido, a percepção do risco pode ser talvez um indicador melhor que a tolerância para representar a vontade do decisor.

A conclusão deste trabalho sobre o processo de tomada de decisão em inovação pode ser expressa através da figura 6.2 .

Figura 6.2 Principais fatores na decisão de inovar

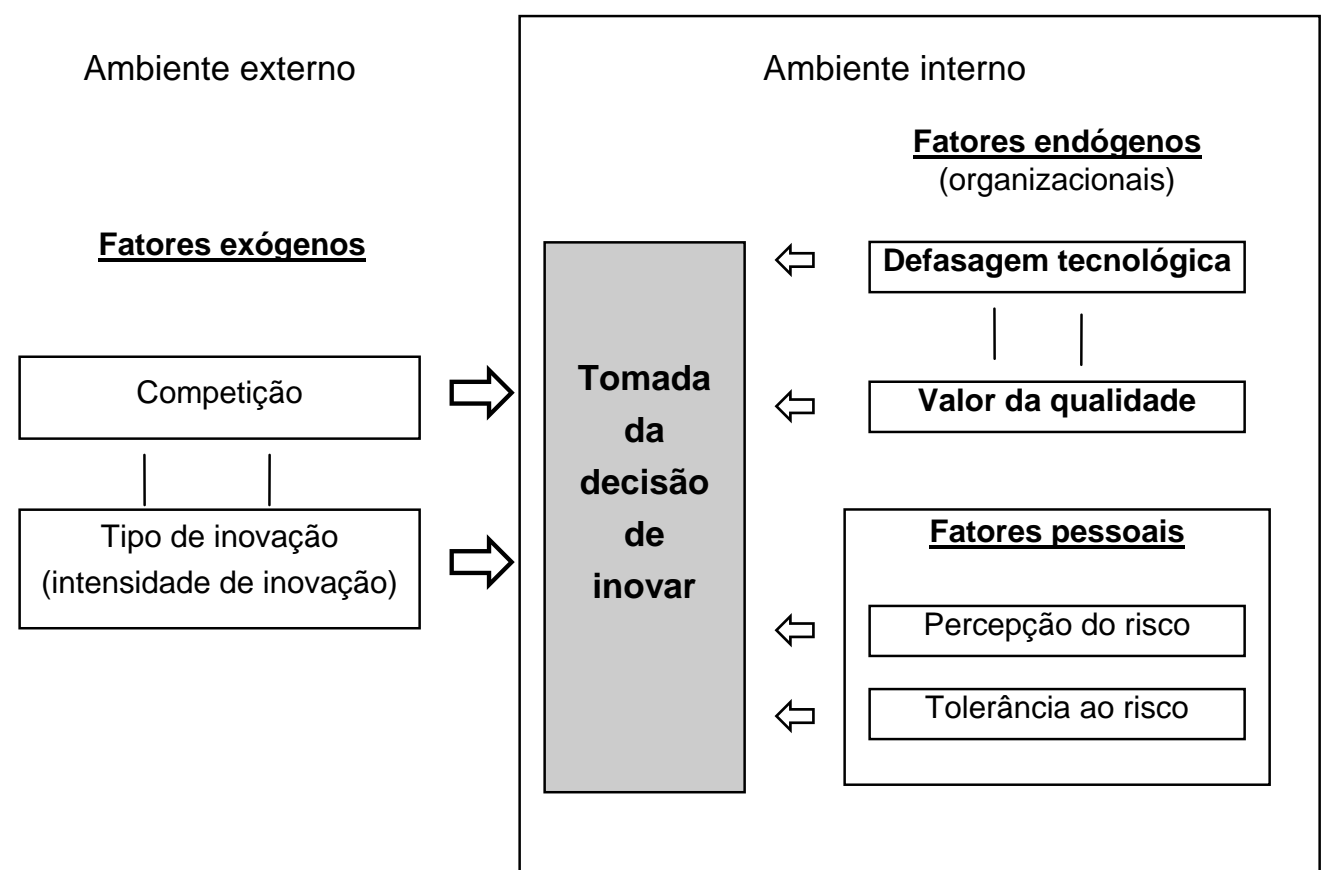

A figura 6.2 representa uma síntese das conclusões deste estudo sobre "por que se decide inovar". O conjunto de fatores que atuam sobre a decisão foram divididos em três componentes: a) externos à empresa, chamados de exógenos; b) internos à empresa, chamados de endógenos; c) fatores pessoais. 
Acredita-se que os fatores exógenos representem as condições necessárias para determinar o quanto uma empresa pode ser inovadora. Caso estes fatores inibam a atividade inovadora, as empresas não terão vantagens competitivas com a inovação e ainda deverão assumir o risco inerente à decisão de inovar para serem inovadoras. $\mathrm{Na}$ situação oposta, quando os fatores exógenos pressionam no sentido da inovação, as empresas precisam da inovação para obter vantagens competitivas, apesar de continuar existindo o risco da inovação. Em suma, acredita-se que os fatores exógenos prevaleçam sobre os outros, embora não sejam suficientes.

Os fatores endógenos e pessoais podem explicar por que em um mesmo setor industrial, seja ele propício ou não para a inovação (em função dos fatores exógenos), é possível se encontrar empresas com diferentes graus de atividade inovadora. Neste sentido, acredita-se que os fatores endógenos e pessoais representem as condições suficientes para determinar o quanto uma empresa é inovadora.

Em resumo, com base nas evidências observadas neste trabalho, foi possível as seguintes conclusões, em caráter de hipótese, sobre "por que se decide inovar":

- Em determinadas situações, a decisão de não inovar ou inovar menos pode ser a mais racional.

- Existem seis fatores, distribuídos em três categorias, que são os principais responsáveis pela tomada de decisão em inovar.

- Os fatores exógenos (aspectos econômicos representados pela competição e tipo de inovação) prevalecem sobre os outros.

- Existe uma relação entre o valor da qualidade para a empresa e o grau de inovação praticado.

- A avaliação da percepção do risco pode contribuir para reduzir os vieses na análise da vontade pessoal do decisor. 


\subsection{Conclusões do estudo sobre como se decide inovar}

O processo de inovação nas pequenas indústrias químicas, aparentemente, pode ser classificado em três tipos possíveis, dependendo basicamente do tipo de inovação e do mercado ao qual se destina a produção da empresa.

Quanto ao tipo de inovação, existem duas grandes categorias, a inovação do produto e a do processo produtivo. A inovação do produto pode ser realizada através da criação, quando a empresa domina a tecnologia, ou por meio da adoção, quando não existe o domínio da tecnologia.

Em geral, as indústrias químicas de pequeno porte praticam a inovação de produto, mas eventualmente, como no caso da empresa B, é possível se encontrar uma pequena empresa tradicional voltada para a inovação de processo. Quanto ao mercado, foi observado que existe uma diferença marcante entre o processo de inovação de produtos voltados para o mercado consumidor e o processo de produtos para os mercados organizacionais. Segundo Kotler (1996), são dois mercados distintos, com diversas características próprias. ${ }^{5}$

A figura 6.3 ilustra os três tipos de processo da inovação propostos.

\section{Quadro 6.3 Processos de inovação na pequena indústria química}

\begin{tabular}{|c|c|c|c|}
\hline & $\begin{array}{l}\text { Geração de } \\
\text { idéias }\end{array}$ & $\begin{array}{l}\text { Seleção das } \\
\text { idéias }\end{array}$ & $\begin{array}{l}\text { Grau de } \\
\text { incerteza }\end{array}$ \\
\hline Processo 1 & \multirow{3}{*}{$\begin{array}{l}\text { - Fornecedores } \\
\text { - Observação das } \\
\text { necessidades } \\
\text { dos clientes }\end{array}$} & \multirow{3}{*}{$\begin{array}{l}\text { - Análise informal } \\
\text { - Avaliação semi } \\
\text { estruturada } \\
\text { - Teste em } \\
\text { laboratório }\end{array}$} & \multirow{3}{*}{$\begin{array}{l}\text { - Moderado } \\
\text { - Pouco recurso } \\
\text { financeiro }\end{array}$} \\
\hline $\begin{array}{c}\text { Mercado } \\
\text { organizacional }\end{array}$ & & & \\
\hline $\begin{array}{c}\text { Criação / adoção } \\
\text { novo produto }\end{array}$ & & & \\
\hline Processo 2 & \multirow{3}{*}{$\begin{array}{l}\text { - Fornecedores } \\
\text { - Observação dos } \\
\text { concorrentes }\end{array}$} & \multirow{3}{*}{$\begin{array}{l}\text { - Análise informal } \\
\text { - Avaliação não } \\
\text { estruturada } \\
\text { - Teste em } \\
\text { laboratório }\end{array}$} & \multirow{3}{*}{$\begin{array}{l}\text { - Pequeno } \\
\text { - Pouco recurso } \\
\text { financeiro }\end{array}$} \\
\hline $\begin{array}{c}\text { Mercado } \\
\text { consumidor }\end{array}$ & & & \\
\hline \begin{tabular}{|c|}
$\begin{array}{c}\text { Adoção de novo } \\
\text { produto }\end{array}$ \\
\end{tabular} & & & \\
\hline Processo 3 & \multirow{3}{*}{$\begin{array}{l}\text { - Observação dos } \\
\text { concorrentes }\end{array}$} & \multirow{3}{*}{$\begin{array}{l}\text { - Análise formal ou } \\
\text { informal } \\
\text { - Avaliação } \\
\text { estruturada }\end{array}$} & \multirow{3}{*}{$\begin{array}{l}\text { - Muito } \\
\text { pequeno } \\
\text { - Muito recurso } \\
\text { financeiro }\end{array}$} \\
\hline $\begin{array}{c}\text { Mercado } \\
\text { organizacional }\end{array}$ & & & \\
\hline $\begin{array}{c}\text { Adoção de novo } \\
\text { processo }\end{array}$ & & & \\
\hline
\end{tabular}

\footnotetext{
${ }^{5}$ Para comparar as diferenças entre os dois mercados ver capítulos 7 e 8 de Kotler, 1996.
} 
Em resumo, com base nas evidências observadas neste trabalho, foi possível as seguintes conclusões, em caráter de hipótese, sobre "como se decide inovar":

- O grau de incerteza nos processos de inovação da pequena indústria química, em geral, é pequeno.

- Os fornecedores, em geral, são uma importante fonte de geração das idéias de inovação.

- O processo de tomada de decisão, em geral, é pouco estruturado.

- As empresas não avaliam formalmente o risco na tomada de decisão em inovação.

\subsection{Conclusões do estudo sobre a proposição}

Quanto à proposição inicial do estudo: "A decisão de desenvolver um novo produto é tomada principalmente em função de: a) contexto no qual a indústria se insere; b) percepção do risco; c) tolerância ao risco do(s) decisor(es)", foi possível observar que ela exprime apenas uma parte da questão. A proposição que expressa as conclusões deste trabalho é:

"A decisão em inovação é tomada em função de: a) contexto no qual a indústria se insere; b) valor da qualidade e defasagem tecnológica da empresa; c) percepção e tolerância ao risco do(s) decisor(es)". 


\subsection{Limitações do estudo}

As principais limitações do estudo são:

a) Quanto ao tipo de metodologia da pesquisa.

Por tratar-se de estudo de múltiplos casos, não é possível a generalização do resultado a um universo maior de empresas. As análises e conclusões ficam restritas aos casos estudados. Segundo Yin (1994), é possível um outro tipo de generalização, chamada por ele de generalização analítica, que tem como objetivo o desenvolvimento da teoria;

b) Amplitude do setor industrial químico

O setor químico abrange uma gama muito grande de diferentes tipos de negócios. Esta amplitude prejudica a análise dos casos estudados, no sentido da profundidade das conclusões, embora colabore na tentativa de generalização teórica.

c) Quanto ao número de casos.

As restrições de recursos e tempo impediram a adoção de um número maior de casos, limitando a confiabilidade dos resultados;

d) Quanto às fronteiras do estudo.

A administração da inovação é inerentemente interdisciplinar e multifuncional. Neste sentido, o estudo foi limitado em amplitude, não abordando outras áreas do conhecimento que interagem com a administração da inovação, tais como a sociologia e a psicologia.

e) Escassez de dados quantitativos

As pequenas empresas, em geral, não possuem registros sobre as informações do processo de inovação, dificultando a análise quantitativa.

\subsection{Sugestões para estudos futuros}


As conclusões deste trabalho, como resultado de uma pesquisa exploratória, são hipóteses sobre a administração da inovação e em particular do processo de tomada de decisão, nas pequenas indústrias químicas. Assim sendo, a primeira sugestão seria a extensão desta pesquisa, na forma de replicação de casos, abrangendo outros conjuntos de pequenas indústrias químicas, o que tornaria possível uma análise mais profunda do processo de administração da inovação neste universo empresarial. Outra possibilidade seria a extensão do estudo para outros setores industriais, mantendo-se o escopo de estudar a tomada de decisão em inovação. Nos dois casos seria possível a análise das conclusões apresentadas neste trabalho, com a finalidade de estabelecer hipóteses de caráter mais genérico e se possível estabelecendo um modelo para a tomada de decisão na pequena empresa.

A conclusão de que, provavelmente, existe uma relação entre o valor da qualidade para a empresa e o grau de inovação praticado poderia ser objeto de uma pesquisa tipo survey para confirmação ou não desta hipótese. Outra hipótese apresentada neste trabalho e que seria passível de verificação, é o fator defasagem tecnológica.

Conforme observado por Yates (1994), muito pouca coisa se conhece sobre o risco assumido de forma não deliberada. Neste sentido, futuros estudos que aprofundassem a questão da percepção do risco, provavelmente seriam de grande valor para a análise da decisão. Estes estudos poderiam ser conduzidos de diversas formas como, por exemplo, uma pesquisa com o objetivo de estabelecer os critérios de medição da percepção do risco. 


\section{CAPÍTULO 7}

\section{ANEXOS}

Este capítulo consta dos seguintes anexos:

- STANDARD INDUSTRIAL CLASSIFICATION (SIC)

- ROTEIRO PARA ENTREVISTA PRELIMINAR

- QUESTIONÁRIO - INFORMAÇÕES GERAIS

- ROTEIRO PARA ENTREVISTA - INOVAÇÃO

- ROTEIRO PARA ENTREVISTA - TOMADA DE DECISÃO

- ROTEIRO PARA ENTREVISTA - TOMADA DE DECISÃO (continuação)

- Roteiro PARA APLICAÇÃo do TESTE dE PERCEPÇÃo

- roteiro para APlicaçÃo do teste de tolerÂNCIA 
STANDARD INDUSTRIAL CLASSIFICATION (SIC)

28 Chemicals And Allied Products

281 Industrial Inorganic Chemicals

2812 Alkalies and chlorine

2813 Industrial gases

2816 Inorganic pigments

2819 Industrial inorganic chemicals

282 Plastics Materials and Synthetics

2821 Plastics materials and resins

2822 Synthetic rubber

2823 Cellulosic manmade fibers

2824 Organic fibers, noncellulosic

283 Drugs

2833 Medicinals and botanicals

2834 Pharmaceutical preparations

2835 Diagnostic substances

2836 Biological products exc. Diagnostic

284 Soap, Cleaners, and Toilet Goods

2841 Soap and other detergents

2842 Polishes and sanitation goods

2843 Surface active agents

2844 Toilet preparations

285 Paints and Allied Products

2851 Paints and allied products

286 Industrial Organic Chemicals

2861 Gum and wood chemicals

2865 Cyclic crudes and intermediates

2869 Industrial organic chemicals

287 Agricultural Chemicals

2873 Nitrogenous fertilizers

2874 Phosphatic fertilizers

2875 Fertilizers, mixing only

2879 Agricultural chemicals

289 Miscellaneous Chemical Products

2891 Adhesives and sealants

2892 Explosives

2893 Printing ink

2895 Carbon black

2899 Chemical preparations 


\section{ROTEIRO PARA ENTREVISTA PRELIMINAR}

\section{INTRODUÇÃO}

- A pesquisa será realizada em cinco indústrias químicas de pequeno porte, com a finalidade de coletar dados para um estudo sobre a decisão no processo de inovação. Este estudo será apresentado na Faculdade de Economia e Administração da USP na forma de uma dissertação de mestrado.

- As empresas participantes da pesquisa não serão identificadas e o pesquisador se compromete a manter sigilo sobre as informações recebidas e consideradas confidenciais.

\section{INFORMAÇÕES GERAIS}

Entrevistado:

Cargo:

Razão social:

Composição acionária:

Ordem de grandeza do faturamento em 1998:

Atividade da empresa:

$\mathrm{N}^{0}$ de empregados:

Data de fundação:

Comentários gerais sobre o negócio e a empresa:

\section{PLANEJAMENTO DA PESQUISA}

Quem participa das decisões estratégicas em inovação?

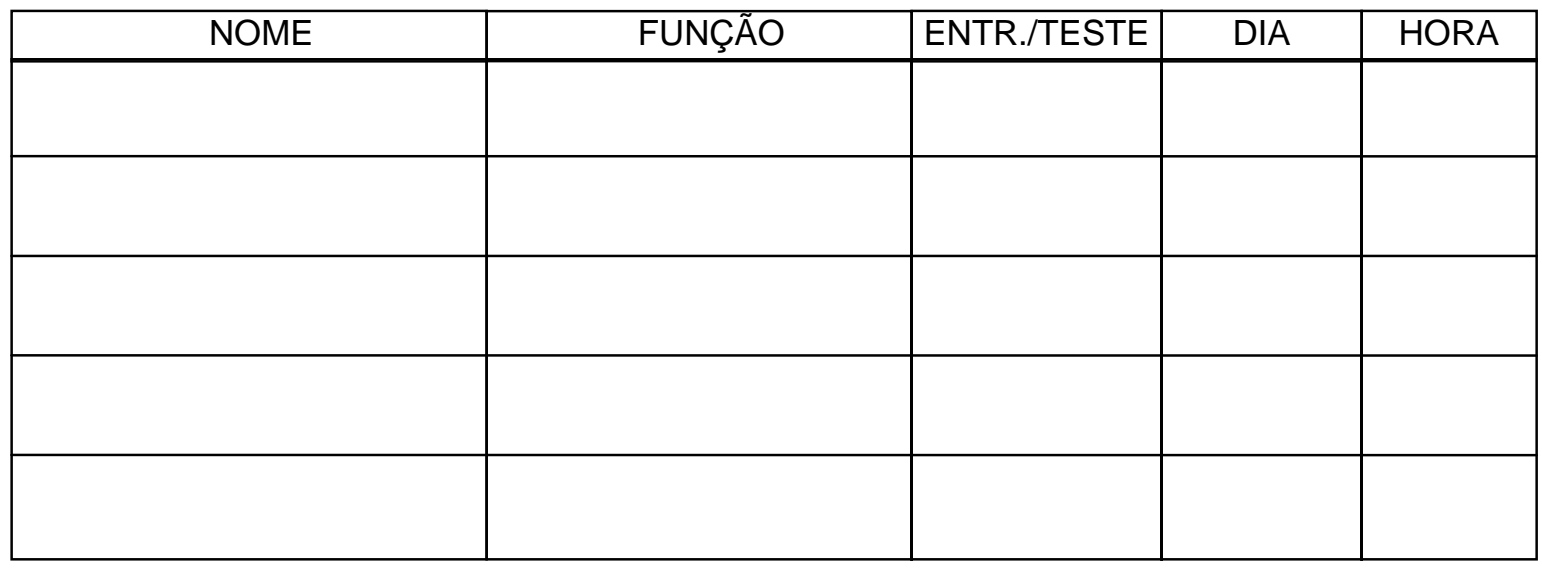


QUESTIONÁRIO - INFORMAÇÕES GERAIS

\section{MERCADO}

Principais clientes (setor industrial e porte):

Principais concorrentes: (porte, nacional?).

Linha de produtos durante o último ano ( $\mathrm{n}^{0}$ de produtos):

Quantidade de produtos lançados nos dois últimos anos e o quanto representa (\%) do faturamento atual:

\section{PRODUÇÃO}

Origem das matérias primas (nacional ou importada):

Tipo de processo (contínuo ou batelada):

Utiliza recursos externos? (quais)

Como é feito o controle da qualidade?

Quais as principais modificações de processo que foram realizadas? (quando, por que, resultados)

\section{FINANÇAS / RH}

Faturamento bruto em 1998: Expectativa para 1999:

Níveis hierárquicos $\left(\mathrm{n}^{0}\right)$ : Quanto representa a mão de obra no custo total (\%):

Estimativa das despesas (em \% do faturamento) com: P\&D Treinamento:

\section{TECNOLOGIA}

Como adquiriu a tecnologia?

Utiliza recursos externos para desenvolvimento de tecnologia? (quais)

Existem outras tecnologias mais novas? (vantagens e desvantagens, acesso)

Como se atualiza com as tecnologias existentes? (bibliografia, seminários, feiras, acordos, etc)

OBSERVAÇÃO: anexar, se disponível: catálogo de produtos, organograma, fluxograma de processo e outras informações sobre a empresa. 


\section{ROTEIRO PARA ENTREVISTA - INOVAÇÃO}

\section{INOVAÇÃO}

Entrevistado:

Data:

1. I

Cargo/Função:

(1) Qual é o objetivo maior da sua empresa?

(2) Qual a relação das inovações com o objetivo da empresa?

(3) Qual a importância dos novos produtos ou processos para a sua empresa? Baixa $\square \quad$ média $\square \quad$ alta $\square$ Por que?

(4) Como você classifica sua empresa em relação aos concorrentes nacionais: pouco inovadora $\square \quad$ inovadora $\square$ muito inovadora

(5) O setor industrial no qual sua indústria está inserido pode ser identificado como: pouco inovador (poucos inovam e sua empresa não se sente pressionada a inovar) neutro (alguns inovam mas não existe pressão dos clientes e concorrentes) muito inovador (os clientes e concorrentes estão constantemente pressionando por inovações)

(6) Considerando a atuação da sua empresa nos últimos anos:

a) Por que sua empresa decidiu desenvolver novos produtos? (resposta 1)

Por que (resposta 1)? (resposta 2) Por que (resposta 2)?

(7) o que fez a sua empresa tomar a decisão de desenvolver novos produtos? sugestão de clientes pesquisa de mercado observação do mercado produtos importados redução das vendas $\square$ concorrentes mudança na legislação adoção de nova tecnologia estratégia da empresa $\square$ excedente de caixa outros

(8) Quais foram as maiores dificuldades encontradas para inovar?

(9) Quais os benefícios que as inovações trouxeram para sua empresa? 


\section{ROTEIRO PARA ENTREVISTA - TOMADA DE DECISÃO}

\section{TOMADA DE DECISÃO}

Entrevistado:

Data: I $\ldots \ldots \ldots$

Cargo/Função:

Considerando o último desenvolvimento de produto ou processo relevante (que está mais forte na memória) para sua empresa, realizado ou em andamento, nos dois últimos anos:

- Identificação da última inovação relevante:

- Identificação da decisão estratégica de desenvolver o produto/processo: (quando foi tomada, fato que marcou

a decisão)

- Como foi o processo de decisão? (etapas: surgimento da idéia, estratégia, alocação de recursos, implementação)

(1) Estrutura da decisão - $(1,2,3,4,5,6,7)$
a) Quem
(áreas)
participou
da
decisão?

b) Qual $0 \quad$ risco $\quad$ e $\quad 0 \quad$ benefício esperado com 0 projeto?

(2) Alternativas - $(1,2,3,4,5,6,7)$

a) Quantas alternativas foram levantadas para analisar 0 projeto?

b) Como foram avaliadas as alternativas?

c) Foi definido um plano para implementar a decisão?

(continua) 


\section{ROTEIRO PARA ENTREVISTA - TOMADA DE DECISÃO (continuação)}

\section{TOMADA DE DECISÃO}

(4) Valores e trade offs - $(1,2,3,4,5,6,7)$
a) Qual a relação entre risco e retorno do projeto?

b) Qual impacto do projeto no fluxo de caixa?

c) Qual custo da falha do projeto?

(5) Raciocínio lógico - $(1,2,3,4,5,6,7)$

a) Foi utilizado algum método quantitativo na análise do projeto? b) A decisão críticas sofreu e

(6) Compromisso para ação - $(1,2,3,4,5,6,7)$ 


\section{ROTEIRO PARA APLICAÇÃO DO TESTE DE PERCEPÇÃO}

\section{INTRODUÇÃO}

Explicar ao entrevistado o objetivo do teste, medir o nível de percepção ao risco. Solicitar a sua colaboração, considerando, tanto quanto possível, o enunciado do teste como uma situação real da empresa.

\section{ENUNCIADO DO TESTE}

Um funcionário apresentou ao seu gerente uma sugestão para desenvolver um novo produto. 0 gerente, por sua vez, antes de emitir sua opinião sobre 0 assunto, realizou algumas pesquisas que demonstraram os seguintes aspectos em relação ao desenvolvimento deste novo produto:

- não existe no mercado um produto com as características sugeridas;

- aparentemente, a empresa possui os conhecimentos básicos e domina a tecnologia necessária para desenvolver, produzir e comercializar o produto;

- o sucesso comercial do novo produto depende principalmente dos fatores: evolução da economia, preço e qualidade do produto;

- existem algumas dificuldades técnicas a serem suplantadas durante o desenvolvimento. Ainda não é possível especificá-las, mas segundo os técnicos trata-se de um desafio inédito e que exigirá muito esforço da equipe técnica.

Nessas condições, imaginando que você é o gerente, estabeleça qual o risco da decisão de desenvolver 0 novo produto na forma de uma probabilidade de fracasso.

\section{ESQUEMA DO TESTE}

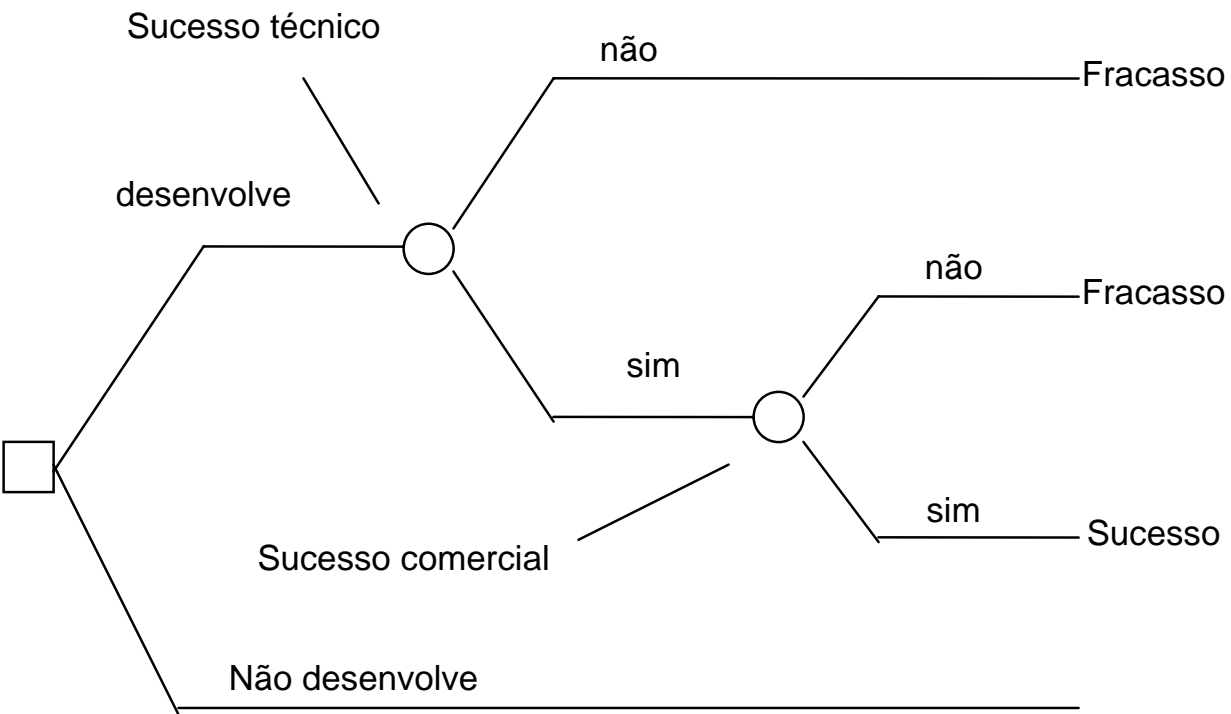




\section{ROTEIRO PARA APLICAÇÃO DO TESTE DE TOLERÂNCIA}

\section{INTRODUÇÃo}

Explicar ao entrevistado o objetivo do teste, medir o nível de tolerância ao risco. Solicitar a sua colaboração, considerando, tanto quanto possível, o enunciado do teste como uma situação real na empresa.

\section{ENUNCIADO DO TESTE}

Qual foi o faturamento bruto da empresa em 1998? (calcular 3\% deste valor, que será chamado de A) Considere a seguinte situação: um novo cliente potencial está instalando uma fábrica e o seu diretor presidente fez uma visita a sua empresa. Após alguns dias você recebe uma consulta desta empresa para fornecer um determinado produto dentro de um certo prazo. Analisando a consulta, a sua empresa verificou que a especificação técnica requerida demandaria o desenvolvimento de um novo produto. Consultando a equipe técnica da sua empresa chegou-se à conclusão que existem algumas dificuldades a serem resolvidas e será necessário comprar alguns equipamentos novos.

Do ponto de vista comercial, o fornecimento do produto para este novo cliente é bastante atraente e pode resultar numa receita líquida de $(\mathrm{A}) \mathrm{R} \$$ por ano, embora exista garantia de compra do produto apenas para 0 primeiro ano.

Realizando uma análise cuidadosa dos riscos técnicos e comerciais existentes, chegou-se à conclusão que havia $50 \%$ de chance de sucesso no investimento.

$\mathrm{O}$ investimento total a ser realizado foi estimado em $\mathrm{A} / 2 \mathrm{R} \$$ e deverá ser feito num prazo de seis meses para atender o prazo requerido pelo cliente.

(Antes de propor a questão, apresentar um esquema do problema)

\section{ESQUEMA DO TESTE}

Ressaltar os dados do problema: 1) existem apenas duas alternativas, investe ou não investe; 2) o fracasso do investimento implica na perda total do valor investido; 3) a probabilidade de sucesso é de $50 \%$ e conseqüentemente a probabilidade de fracasso também é de $50 \%$.

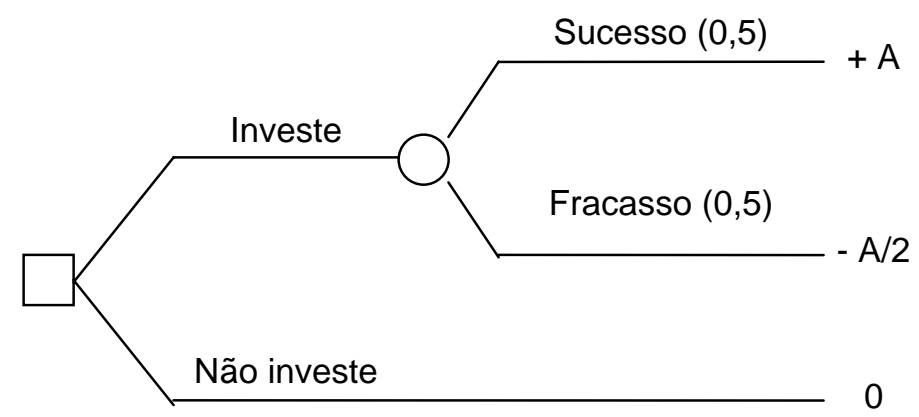

(perguntar ao entrevistado) Qual a sua decisão? Investe ou não investe?

Em função da resposta: a) se investe, dobrar o valor de A e repetir o teste; b) se não investe, reduzir o valor de A pela metade e repetir o teste.

Independente da resposta no segundo teste, questionar o entrevistado sobre o valor limite, isto é, até quanto está disposto a investir ou qual o valor acima do qual ele não investe. 


\section{CAPÍTULO 8}

\section{REFERÊNCIAS BIBLIOGRÁFICAS}

ABERNATHY, W. J. \& UTTERBACK, J. M. (1978) Patterns of industrial innovation. Technology Review, vol. 80, no 7 (June/July 1978) p. 639-656, citado por UTTERBACK, J. M. (1994) Mastering the dynamics of innovation: how companies can seize opportunities in the face of technological change. Boston:HBS.

ACS, Z. J. \& AUDRETSCH, D. B. (1991) Innovation and small firms. 2.ed. Cambridge: MIT Press.

ACS, Z. J. \& TARPLEY, F. A. \& PHILLIPS, B. D. (1998) The new american evolution: the role and impact of small firms. A report on small firms prepared by the Office of Economic Research of the U. S. Small Business Administration's Office of Advocacy. June, 1998. USA: SBA.

ALMEIDA, H. S. (1981) Um estudo do vínculo tecnológico entre: pesquisa, engenharia, fabricação e consumo. Tese de doutoramento, Escola Politécnica da USP, S. Paulo. Citado por KRUGLIANSKAS, I. (1996) Tornando a pequena e média empresa competitiva. São Paulo: IEGE.

ARCHIBUGI, D. \& EVANGELISTA, R. \& SIMONETTI, R. (1993) Concentration, firm size, and innovation. Evidence from innovation costs. Discussion paper $N^{\circ} 9$, SPRU, University of Sussex, November 1993.

ARNOLD, R. H. \& KEELIN, T. W. (1994) R\&D strategic management: value creation through people. IBC conference, "professionalism \& Excellence in R\&D. London, December 1994.

ASSOCIAÇÃO BRASILEIRA DA INDÚSTRIA QUÍMICA E DE PRODUTOS DERIVADOS, ABIQUIM. Sistema dinâmico de informações, 1998. São Paulo: ABIQUIM.

ASSOCIAÇÃO NACIONAL DE PESQUISA E DESENVOLVIMENTO DAS EMPRESAS INDUSTRIAIS, ANPEI. (1997) Indicadores empresariais de inovação tecnológica: resultados da base de dados ANPEI. São Paulo: ANPEI.

BALDWIN, K. (1994) Innovation: the key to success in small firms. Statistics Canada, Ottawa, citado por TIDD, J. \& BESSANT, J. \& PAVITT, K. (1997) Managing innovation - integrating technological, market and organization change. Chichester, UK: John Wiley.

BARBER, P. J. \& LEGGE, D. (1976) Percepção e informação. HERRIOT, P. (Org.) Rio de Janeiro: Zahar.

BARON, J. (1994) Thinking and deciding. 2. ed. London: Cambridge University Press. 
BAZERMAN, M. H. (1994) Judgment in managerial decision making. 3 ed. New York: John Wiley \& Sons.

BEKMAN, O. R. \& COSTA NETO, P. L. O. (1980) Análise estatística da decisão. São Paulo: Edgar Blücher.

BERNSTEIN, P. L. (1997) Desafio aos deuses: a fascinante história do risco. Rio de Janeiro: Campus.

BROADBENT, D. E. (1958) Perception and Communication. Oxford: Pergamon, citado por BARBER, P. J. \& LEGGE, D. (1976) Percepção e informação. HERRIOT, P. (Org.) Rio de Janeiro: Zahar.

BRUNER, J. S. \& POSTMAN, L. J. (1949) On the perception of incongruity: a paradigma. Journal of personality, citado por PLOUS, S. (1993) The psychology of judgment and decision making. New York: McGraw-Hill.

CAMPOS, V. F. (1992) TQC: controle da qualidade total (no estilo japonês). 5. ed. Rio de Janeiro: Bloch.

CASTRO, C. M. (1977) A prática da pesquisa. São Paulo: McGraw-Hill.

CLARK, K. B. \& WEELWRIGHT, S. C. (1993) Managing new product and process development: text and cases. New York: The Free press.

CLEMEN, R. T. (1996) Making hard decisions: an introduction to decision analysis. 2. ed. Belmont: Duxbury.

COINCO (1985) - CONSELHO ESTADUAL DE POLÍTICA INDUSTRIAL, COMERCIAL E AGROINDUSTRIAL. A indústria química-petroquímica brasileira: diagnóstico setorial. São Paulo: outubro de 1985.

CORNELSEN, S. G. \& HENRIQUES, J. P. \& SUSTERAS, M. V. (1998) Competitividade nas MPEls: o programa mobilização tecnológica. Artigo apresentado no XX Simpósio de Gestão da Inovação Tecnológica, realizado pelo PGT/USP em novembro de 1998, São Paulo.

CURY, A. (1983) Organização e métodos: uma visão holística. 6. ed. São Paulo: Atlas.

DAVIDOFF, L. L. (1983) Introdução à psicologia. São Paulo: Makron.

DAVIS, D. (1996) Business research for decision making. 4. ed. USA: Duxbury.

DAVIS, P. (1983) Realizing the potential of the family business. Organizational Dynamics, Vol. 12 (summer 1983), pp. 53-54. Citado por LONGENECKER, G. \& MOORE, W. C. \& PETTY,J. W. (1994) Small business management: an entrepeneurial emphasis. 9. Ed. Cincinnati: ITP.

DOSI, G. (1984) Technical change and industrial transformation. New York: St. Martin's Press.

DPL, Decision Programming Language. (1995) Decision analysis software for microsoft windows. Advanced version user guide. USA: Duxbury Press. 
DRUCKER, P. (1985) Innovation and entrepreneurship. citado por TIDD, J. \& BESSANT, J. \& PAVITT, K. (1997) Managing innovation - integrating technological, market and organization change. Chichester, UK: John Wiley.

DYER, Jr. W. G. (1986) Cultural change in family firms. San Francisco: Jossey-Bass Publisher, chapter 2. Citado por LONGENECKER, G. \& MOORE, W. C. \& PETTY,J. W. (1994) Small business management: an entrepeneurial emphasis. 9. Ed. Cincinnati: ITP.

EDWARDS, K. L. \& GORDON, T. J. (1984) Characterization of innovations introduced on the U.S. market in 1982. The futures group, prepared for U.S. Small Business Administration under contract no SBA 6050-0 -82, citado por ACS, Z. J. \& AUDRETSCH, D. B. (1991) Innovation and small firms. 2.ed. Cambridge: MIT Press.

ELLSBERG, D. (1961) Risk, ambiguity, and the Savage axioms. Quaterly Journal of Economics, citado por YATES, J. F. \& STONE, E. R. (1994) The risk construct. In: YATES, J. F. (edit.) Risk-taking behavior. England: John Wiley \& Sons.

ENCICLOPÉDIA DE PSICOLOGIA (1975) Encyclopedia of psychology. Vol. 2 EYSENCK, H. J. \& ARNOLD, W. J. \& MEILI, R. (Edit.) Great Britain: Fontana.

ENGEL, J. F. \& BLACKWELL, R. D. \& MINIARD, P. W. (1995) Consumer behavior. 8. ed. Forth Worth: Dryden.

FISCHOFF, B. (1985) Managing risk perceptions. Issues in science and technology. citado por YATES, J. F. \& STONE, E. R. (1994) The risk construct. In: YATES, J. F. (edit.) Risk-taking behavior. England: John Wiley \& Sons.

FISHBURN, P. C. (1984) SSB utility theory and decision making under uncertainty. Mathematical Social Sciences, 8, 253-285, citado por PLOUS, S. (1993) The psychology of judgment and decision making. New York: McGraw-Hill.

FREEMAN, C. (1974) The economics of industrial innovations. Penguin Books, London, citado por KAY, N. M. (1979) The innovating firm. London: The Macmillan Press.

FREEMAN, C. \& SOETE, L. (1997) The economics of industrial innovation. 3. ed. Cambridge: MIT Press.

FUNDAÇÃO INSTITUTO BRASILEIRO DE GEOGRAFIA E ESTATÍSTICA, IBGE. Anuário estatístico do Brasil, 1997. Rio de Janeiro: IBGE.

FURTADO, C. (1998) O capitalismo global. 2.ed. Rio de Janeiro: Paz e Terra.

GAZETA MERCANTIL LATINO AMERICANA (1999) "1000 maiores empresas da América latina." Publicado por Gazeta Mercantil S/A Informações eletrônicas em sua página na WEB, WWW.gazetamercantil.com.br

GIBSON, J. L. \& IVANCEVICH, J. M. \& DONNELLY, Jr. J. H. (1988) Organizações: comportamento, estrutura, processos. São Paulo: Atlas.

GITMAN, L. J. (1997) Princípios de administração financeira. 7. ed. São Paulo: Harbra. 
GOLD, B. (1971) Explorations in managerial economics: productivity, costs, technology and growth. Macmillan, London, citado por KAY, N. M. (1979) The innovating firm. London: The Macmillan Press.

GOLUB, A. L. (1997) Decision analysis: an integrated approach. New York: Wiley.

HAMEL, G. \& PRAHALAD, C. K. (1994) Competing for the future. Boston: HBS.

HAMMOND, J. S. \& KEENEY, R.L. \& RAIFFA, H. (1999) Smart choices: a practical guide to making better decisions. Boston: HBS.

HARDY, O. C. (1923) Risk and risk-bearing. Chicago: University Press, citado por STRASSMANN, W. P. (1959) Risk and innovation: american manufacturing methods during the nineteenth century. New York: Cornell University Press.

HERRIOTT, R. E. \& FIRESTONE, W. A. (1983) Multisite qualitative policy research: optimizing description and generalizability. Education Researcher,12, 14-19. Citado por YIN, R. K. (1994) Case study research: design and methods. 2. ed. Applied social research methods series. volume 5. California: Sage.

HOWARD, R. . (1988) Decision analysis: practice and promise. Management Science. Vol. 34, No 6, June 1988, USA.

JACOBY, J. \& KAPLAN, L. B. (1972) The components of perceived risk. In M. Ventakesan (Ed.) Proceedings of the third annual conference of the association for consumer research. Chicago: Association for consumer research, citado por YATES, J. F. \& STONE, E. R. (1994) The risk construct. In: YATES, J. F. (edit.) Risk-taking behavior. England: John Wiley \& Sons.

KAHNEMAN, D. \& TVERSKY, A. (1979) Prospect theory:an analysis of decision under risk. Econométrica, citado por YATES, J. F. \& STONE, E. R. (1994) The risk construct. In: YATES, J. F. (edit.) Risk-taking behavior. England: John Wiley \& Sons.

KAMM, J. B. (1987) An integrative approach to managing innovation. Lexington: Lexington Books.

KAPLAN, S. \& GARRICK, B. J. (1981) On the quantitative definition of risk. Risk analysis, citado por YATES, J. F. \& STONE, E. R. (1994) The risk construct. In: YATES, J. F. (edit.) Risk-taking behavior. England: John Wiley \& Sons.

KAY, N. M. (1979) The innovating firm. London: The Macmillan Press.

KERLINGER, F. N. (1980) Metodologia da pesquisa em ciências sociais: um tratamento conceitual. São Paulo: E.P.U.

KOTLER, P. (1996) Administração de marketing: análise, planejamento, implementação e controle. 4. ed. São Paulo: Atlas.

KRUGLIANSKAS, I. (1996) Tornando a pequena e média empresa competitiva. São Paulo: IEGE.

LANGRISH, J \& GIBBONS, M. \& EVANS, P. \& JEVONS, F. (1972) Wealth from knowledge. London:Macmillan, citado por FREEMAN, C. \& SOETE, L. (1997) The economics of industrial innovation. 3. ed. Cambridge: MIT Press. 
LAROUSSE CULTURAL (1998) Grande enciclopédia. São Paulo: Nova Cultural.

LEONARD-BARTON, D. (1998) Wellsprings of knowledge: building and sustaining the sources of innovation. Boston: HBS.

LONGENECKER, G. \& MOORE, W. C. \& PETTY,J. W. (1994) Small business management: an entrepeneurial emphasis. 9. Ed. Cincinnati: ITP.

LUCE, R. D. \& RAIFFA, H. (1957) Games and decision. New York: Wiley, citado por YATES, J. F. \& STONE, E. R. (1994) The risk construct. In: YATES, J. F. (edit.) Risk-taking behavior. England: John Wiley \& Sons.

MACCRIMMON, K. R. \& WEHRUNG, D. A. (1986) Taking risks: the management of uncertainty. New York: Free Press.

MANSFIELD, E. \& RAPOPORT, J. (1975) The costs of industrial product innovations. In: MANSFIELD, E. (1995) Innovation, technology and the economy: selected essays of Edwin Mansfield. Vol. 1 UK: Edward Elgar.

MARCH, J. G. \& SHAPIRA, Z. (1987) Managerial perspectives on risk and risk taking. Management Science, citado por YATES, J. F. \& STONE, E. R. (1994) The risk construct. In: YATES, J. F. (edit.) Risk-taking behavior. England: John Wiley \& Sons.

MATHESON, D. \& MATHESON, J. (1998) The smart organization: creating value through strategic $R \& D$. Boston: HBS.

MATTAR, F. N. (1996) Pesquisa de marketing. v.1. 3. ed. São Paulo: Atlas.

MAXIMIANO, A. C. A. (1997) Teoria geral da administração: da escola científica à competitividade em economia globalizada. São Paulo: Atlas.

McMILLEN, D. \& SMITH, S. \& WELLS-PARKER, E. (1989) The effects of alcohol, expectancy, and sensation seeking on driving risk taking. Addictive Behaviors, 14,477-483. citado por PLOUS, S. (1993) The psychology of judgment and decision making. New York: McGraw-Hill.

MILGROM, P. \& ROBERTS, J. (1992) Economics, organization \& management. New Jersey: Prentice Hall.

MILLER, D. W. \& STARR, M. K. (1970) Estrutura das decisões humanas. Rio de Janeiro: Fundação Getúlio vargas.

MOORE, P. G. (1997) The business of risk. Cambridge: Cambridge University Press.

MORAY, N. (1969) Attention: seletive processes in vision and hearing. Londres: Hutchinson Educacional, citado por BARBER, P. J. \& LEGGE, D. (1976) Percepção e informação. HERRIOT, P. (Org.) Rio de Janeiro: Zahar.

NELSON, R. R. \& WINTER, S. G. (1996) An evolutionary theory of economic change. 6 ed. USA: The Belknap Press. 
PAVITT, K. \& WALD, S. (1971) The conditions for success in technological innovation. OECD, Paris, citado por ACS, Z. J. \& AUDRETSCH, D. B. (1991) Innovation and small firms. 2.ed. Cambridge: MIT Press.

PAYNE, J. W. (1973) Alternative approaches to decision making under risk: moments versus risk dimensions. Psychological Bulletin, 80, 439-453, citado por PLOUS, S. (1993) The psychology of judgement and decision making. New York: McGraw-Hill.

PICKLE, H. B. \& ABRAHAMSOM, R. L. (1990) Small business management. 5. ed. New York: Wiley.

PISANO, G. P. (1997) The development factory: unlocking the potential of process innovation. Boston: HBS.

PLOUS, S. (1993) The psychology of judgment and decision making. New York: McGraw-Hill.

PORTER, M. E. (1998) A vantagem competitiva das nações. In: MONTGOMERY, C. A. \& PORTER, M. E. (Org.) Estratégia: a busca da vantagem competitiva. 3.ed. Rio de Janeiro: Campus.

PORTER, M. E. (1986) Estratégia competitiva: técnicas para a análise de indústrias e da concorrência. 9. ed. Rio de Janeiro: Campus.

PRATTEN, C. F. (1991) The competitiveness of small firms. Cambridge: Cambridge University Press.

PRICE, D. J. de Solla (1965) Is technology historically independent of science? Technology and Culture, vol. 6, $\mathrm{n}^{\circ}$ 4, p. 553, citado por FREEMAN, C. \& SOETE, L. (1997) The economics of industrial innovation. 3. ed. Cambridge: MIT Press.

QUEIROZ, E. K. R. (1995) Qualidade segundo Garvin. São Paulo: Annablume.

RATTNER, H. (org.) (1985) Pequena empresa: o comportamento empresarial na acumulação e na luta pela sobrevivência. São Paulo: Brasiliense.

REINERTSEN, D. G. (1997) Managing the design factory: a product developer's toolkit. New York: Free press.

RENDER, B. \& STAIR, R. M. (1994) Quantitative analysis for management. 5. ed. New Jersey: Prentice Hall.

ROBERT, M. (1995) A estratégia pura e simples da inovação do produto. Rio de Janeiro: Nórdica.

ROBERTSON, T. S. (1967) The process of innovation and the diffusion of innovation. Journal of Marketing, January 1967, p. 14-19, citado por ENGEL, J. F. \& BLACKWELL, R. D. \& MINIARD, P. W. (1995) Consumer behavior. 8. ed. Forth Worth: Dryden.

ROBBINS, S. (1990) Organization theory. Englewood Cliffs: Prenti-Hall, citado por MAXIMIANO, A. C. A. (1997) Teoria geral da administração: da escola científica à competitividade em economia globalizada. São Paulo: Atlas. 
ROGERS, E. M. (1995) Diffusion of innovations. 4. ed. New York: free Press.

ROSS, S. A. \& WESTERFIELD, R. W. \& JAFFE, J. F. (1995) Administração financeira. São Paulo: Atlas.

ROTHWELL, R. \& ZEGVELD, W. (1983) Innovation and the small and medium sized firm. London: Frances Printer.

RUSSO, J. E. \& SCHOEMAKER, P. J. H. (1993) Tomada de decisões: armadilha. São Paulo: Saraiva.

SAVAGE, L. J. (1954) The foundations of statistics. New York: Wiley, citado por PLOUS, S. (1993) The psychology of judgment and decision making. New York: McGraw-Hill.

SAMUELSON, P. B. \& NORDHAUS, W. D. (1993) Economia. 14. ed. Portugal: McGraw-Hill.

SBA, Small Business Administration (1998) The new american evolution: the role and impact of small firms. Written by ACS, Z. J. \& TARPLEY, F. A. \& PHILLIPS, B. D. Publicado em sua página na WEB: www.sba.gov USA: SBA.

SCHERER, F. M. (1988) Testimony before the subcommittee on monopolies and comercial law. Committee on the Judiciary, U.S. House of Representatives, February 24, citado por ACS, Z. J. \& AUDRETSCH, D. B. (1991) Innovation and small firms. 2.ed. Cambridge: MIT Press.

SCHON, D. A. (1967) Technology and change: the new heraclitus. Pergamon Press, Oxford, citado por KAY, N. M. (1979) The innovating firm. London: The Macmillan Press.

SCHRAMM, W. (1971) Notes on case studies of instructional media projects. Working paper, the Academy for Educational Development, Washington, DC. Citado por YIN, R. K. (1994) Case study research: design and methods. 2. ed. Applied social research methods series volume 5 California: Sage.

SCHUMPETER, J. A. (1961) Teoria do desenvolvimento econômico. Rio de Janeiro: Fundo de Cultura.

SEADE, Sistema Estadual de Análise de Dados Paep, pesquisa da atividade econômica paulista. Publicação de responsabilidade da Secretaria de Estado dos Negócios de Economia e Planejamento do Governo do Estado de São Paulo, 1998.

SEBRAE SP (1998) Avaliação trimestral das MPE paulistas, I trimestre/98. São Paulo: SEBRAE.

(1993) Indicadores de competitividade para as micro e pequenas empresas industriais no Brasil. Projeto SEBRAE/UFRJ-IEI. Brasília: SEBRAE.

SHIMSHONI, D. (1966) Aspects of scientific entrepreneurship. Dphil thesis, Harvard, citado por FREEMAN, C. \& SOETE, L. (1997) The economics of industrial innovation. 3. ed. Cambridge: MIT Press. 
SILVA, D. S. \& GODOY, J. A. \& CUNHA, J. X. (1998) Micro e pequenas empresas: manual de procedimentos contábeis. In: NETO, P. C. (coord.) 2 ed. Brasília: SEBRAE.

SIMON, H. A. (1965) The shape of automation for men and management. Harper \& Row, New York, citado por KAY, N. M. (1979) The innovating firm. London: The Macmillan Press.

SITIVESP - Sindicato da Indústria de Tintas e Vernizes do Estado de São Paulo. Indicadores econômicos na página da WEB WWW.sitivesp.org.

SKINNER, B. F. (1999) Sobre o behaviorismo. 11 ed. São Paulo: Cultrix.

SLACK, N. \& CHAMBERS, S. \& HARLAND, C. \& HARRISON A. \& JOHNSTON, R. (1997) Administração da produção. São Paulo: Atlas.

SLOVIC, P. \& FISCHHOFF, B. \& LICHTENSTEIN, S. (1982) Facts versus fears: understanding perceived risk. In: KAHNEMAN, D. \& SLOVIC, P. \& TVERSKY, A. (edit.) Judgment under uncertainty: heuristics and biases UK: Cambridge University Press.

SOARES, M. M. (1994) Inovação tecnológica em empresas de pequeno porte. Brasília: Edição SEBRAE.

SPÄTH, B. (1993) Small firms in latin america: prospects for economic and socially viable development? In: SPÄTH, B. (edit.) Small firms and development in latin america: the role of the institutional enviroment, human resources and industrial relations. Geneva: International Institute for Labour Studies.

STAKE, R. E. (1995) The art of case study research. California: Sage.

SHERWIN WILLIAMS Informações sobre tintas e revestimentos. Página da WEB, WWW.sherwin williams.com.br.

TVERSKY, A. \& KAHNEMAN, D. (1973) Availability: a heuristic for judging frequency and probability. Cognitive Psychology, citado por BAZERMAN, M. H. (1994) Judgment in managerial decision making. 3 ed. New York: John Wiley \& Sons.

TIDD, J. \& BESSANT, J. \& PAVITT, K. (1997) Managing innovation - integrating technological, market and organization change. Chichester, UK: John Wiley.

TURBAN, E. \& MEREDITH, J. R. (1994) Fundamentals of management science. 6. ed. Boston: Irwin.

UTTERBACK, J. M. (1994) Mastering the dynamics of innovation: how companies can seize opportunities in the face of technological change. Boston:HBS.

Von NEUMANN, J. \& MORGENSTERN, O. (1947) Theory of games and economic behavior. Princeton, NJ: Princeton University press, citado por PLOUS, S. (1993) The psychology of judgement and decision making. New York: McGrawHill.

WERTHEIMER, M. (1958) Principles of perceptual organization. In: BEARDSLEE, D. C. \& WERTHEIMER, M. (Orgs.) Readings in perception. Princeton, NJ.: Van Nostrand, citado por BARBER, P. J. \& LEGGE, D. (1976) Percepção e informação. HERRIOT, P. (Org.) Rio de Janeiro: Zahar. 
YATES, J. F. \& STONE, E. R. (1994) The risk construct. In: YATES, J. F. (edit.) Risktaking behavior. England: John Wiley \& Sons.

YATES, J. F. (1994) Epilogue. In: YATES, J. F.(edit.) Risk-taking behavior. England: John Wiley \& Sons.

YIN, R. K. (1994) Case study research: design and methods. 2. ed. Applied social research methods series. volume 5. California: Sage.

ZANGWILL, W. I. (1993) Lightning strategies for Innovation: how the world's best firms create new products. New York: Lexington. 